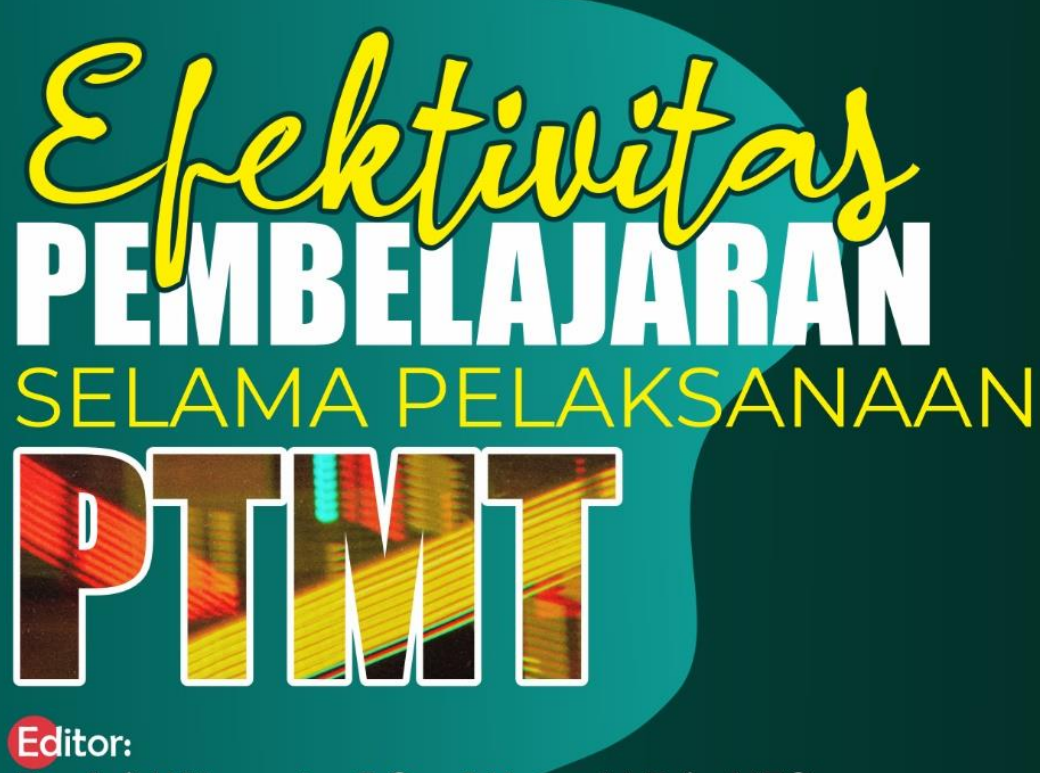

Dr. Adi Wijayanto, S.Or., S.Kom., M.Pd., AIFO.

Dr. Rita Meutia, SE, MSi, Ak.

Dr. Sapto Wibowo, M.Pd.

Dian Armada Pradana, S.Pd.

\title{
Pengantar:
}

Prof. Dr. H. Akhyak, M.Ag. Direktur Pascasarjana UIN SATU

(Sayyid Ali Rahmatullah Tulungagung)
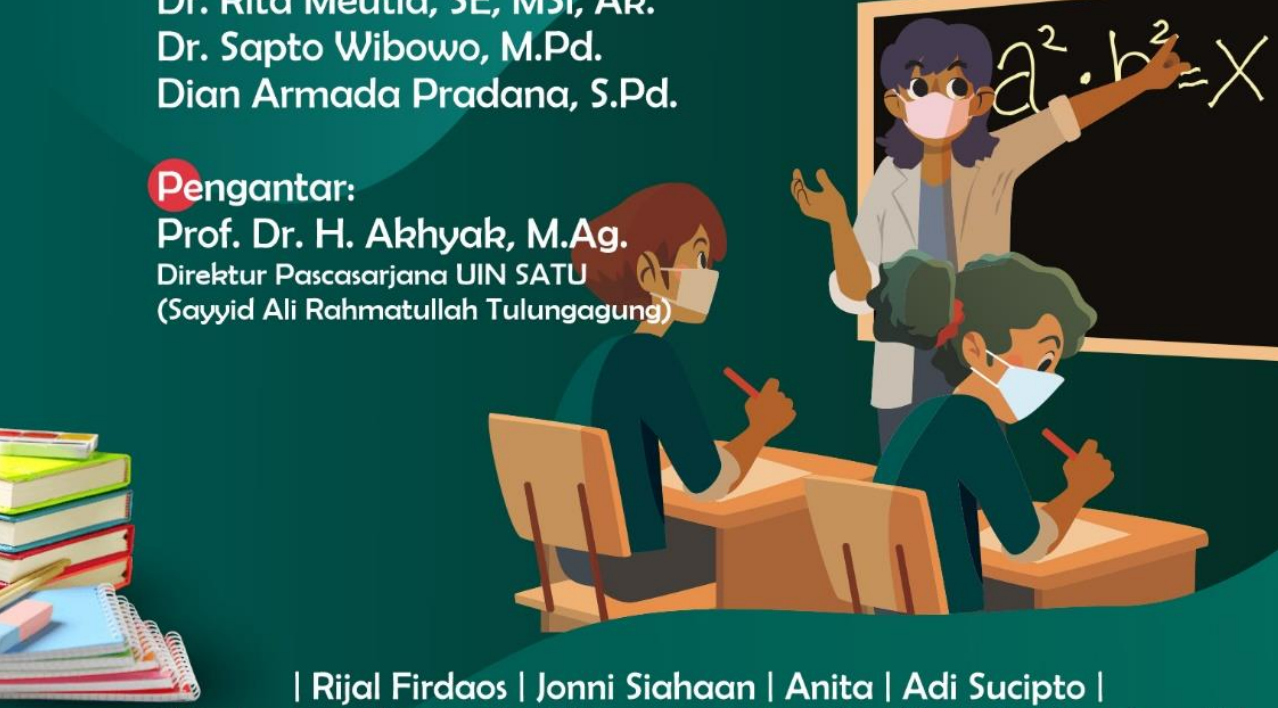

| Mochammad Ronaldy Aji Saputra | Dewi Sartika | Ani Kurniawati | | Yayat Suharyat | Diki Septiawan | Dintya Ayu Purika | Karwanto | | Abdul Malik Iskandar | Syarifuddin | Wara Sabon Dominikus | | Abdul Khamid | Nurmalina | Julia Noviani | Sholihatul Hamidah Daulay | | Susana Labuem | Octa Prasetya Adi | Dede Risma Ginanjar |

| Siyonol Ida Farida | Sofia G. Un Lala | Mutik Nur Fadhilah | | Agus Mukholid| Yudo Harviantol Dony Andri Setiawan | | Destrianal Rini Andrianil Mia Kusumawati | 


\title{
EFEKTIVITAS PEMBELAJARAN SELAMA PELAKSANAAN PTMT
}

\author{
Rijal Firdaos - Jonni Siahaan - Anita - Adi Sucipto - \\ Mochammad Ronaldy Aji Saputra - Dewi Sartika - Ani Kurniawati - \\ Yayat Suharyat - Diki Septiawan - Dintya Ayu Purika - Karwanto - \\ Abdul Malik Iskandar - Syarifuddin - Wara Sabon Dominikus - \\ Abdul Khamid - Nurmalina - Julia Noviani - Sholihatul Hamidah Daulay - \\ Susana Labuem - Octa Prasetya Adi - Dede Risma Ginanjar - Siyono - \\ Ida Farida - Sofia G. Un Lala - Mutik Nur Fadhilah - Agus Mukholid - \\ Yudo Harvianto - Dony Andri Setiawan - Destriana - Rini Andriani - \\ Mia Kusumawati
}

Editor:

Dr. Adi Wijayanto, S.Or., S.Kom., M.Pd., AIFO. Dr. Rita Meutia, S.E., M.Si., Ak. Dr. Sapto Wibowo, M.Pd. Dian Armada Pradana, S.Pd.

Pengantar:

Prof. Dr. H. Akhyak, M.Ag. Direktur Pascasarjana UIN SATU (Sayyid Ali Rahmatullah Tulungagung) 


\section{EFEKTIVITAS PEMBELAJARAN SELAMA PELAKSANAAN PTMT}

Copyright (C) Rijal Firdaos, dkk., 2021

Hak cipta dilindungi undang-undang

All right reserved

Editor: Adi Wijayanto, dkk.

Layouter: Muhamad Safi'i

Desain cover: Dicky M. Fauzi

viii + 216 hlm: 14 x $21 \mathrm{~cm}$

Cetakan: Pertama, Desember 2021

ISBN: 978-623-6364-65-9

\section{Anggota IKAPI}

Hak cipta dilindungi undang-undang. Dilarang memplagiasi atau memperbanyak seluruh isi buku ini tanpa izin

tertulis dari penerbit.

Diterbitkan oleh:

\section{Akademia Pustaka}

Perum. BMW Madani Kavling 16, Tulungagung

Telp: 081216178398

Email: redaksi.akademia.pustaka@gmail.com

Website: www.akademiapustaka.com 


\section{Kata Pengantar}

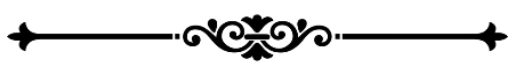

Ahamdulillahi Rabbilalamin kehadirat Allah SWT yang
maha kuasa atas perkenan-Nya buku bunga rampai edisi
September tahun 2021 yang berjudul "Efektivitas Pembelajaran selama Pelaksanaan PTMT" dapat diselesaikan dengan sebaik-baiknya atas sumbangsih ide/gagasan dan pemikiran dari para pakar pendidikan dan stake holder.

Proses belajar di dunia pendidikan pada pasca pandemi covid-19 memang akan berjalan unik dan menarik untuk dikaji secara empiris, teoretis dan berbagai pengalaman yang dialami guru dan murid selama proses belajar daring (online) dapat dijadikan inspirasi untuk diurai dalam wujud tulisantulisan ringan yang layak untuk di ketahui banyak orang dan layak dimuat dalam Buku Bunga Rampai ini. Para penulis buku ini akan berbeda sudut pandangnya melihat penyelenggaraan pendidikan di pasca pandemi, tetapi pada prinsipnya sama yakni bagaimana proses belajar di sekolah dan di rumah siswa dapat mengikutinya dan berbagai materi yang tertinggal selama proses belajar daring selama kurun waktu 2 tahun ini dijadikan dasar berpikir yang kuat untuk mau lebih meningkatkan lagi keinginan belajarnya baik di sekolah maupun di rumah.

Pendidikan pada prinsipnya harus berada di garda terdepan bagi bangsa Indonesia secara khusus bagi para generasi milineal bangsa ini, olehkarena estafet kepemimpinan yang akan melanjutnya negara ini dimasa akan datang terletak pada bagaimana mutu pendidikan saat ini. Dalam dunia olahraga, jika penulis analogikan bahwa Indonesia bercita-cita masuk dalam 10 besar ranking dunia di 
Olimpiade tahun 2032, maka jawabnya ada di pembinaan olahraga prestasi anak Indonesia usia 10-12 tahun saat ini. Pembinaan harus berjangka panjang yakni sekitar 8-10 tahun dan umur ini dijadikan acuan guna menyongsong prestasi 10 besar dunia di Olimpiade 2032. Dalam dunia pendidikan juga harus demikian, apa yang terjadi pada anak didik di tahun 2022, tentu akan dlihat bagaimana generasi bangsa Indonesia di tahun 2032. Apakah berelasi dengan munculnya generasi muda Indonesia yang handal menjawab tantangan era globalisasi di tahun 2032. Seperti apa kualifikasinya, ini adalah buah dari apa yang dilakukan pada anak didik di tahun 2022 ini. Olehkarena itu, proses pendidikan di pasca pandemi yang rencana akan di mulai tahun 2022 harus diwujudkan secara berkualitas.

Kehadiran buku bunga rampai ini sangatlah tepat di tengah kondisi pandemi Covid-19 varian baru. Semoga tulisan ringan dengan berbagai topik yang menarik disampaikan para penulis, memberi manfaat bagi para pembaca, guru, siswa, orangtua. Upaya menghilangkan virus Covid-19 terus dilakukan Pemerintah RI tetapi penyiapan SDM unggul tidak boleh terhenti olehkarena ganasnya penyebaran Virus corona yang berimbas membuat banyak pihak berpikir pesimis dan optimis yang bercampur aduk dalam pikirannya termasuk para guru dan siswa.

Tulungagung, 11 Desember 2021

Prof. Dr. H. Akhyak, M.Ag.

Direktur Pascasarjana UIN SATU 


\section{Daftar Isi}

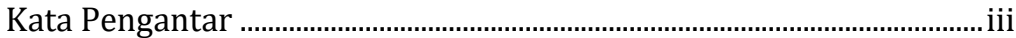

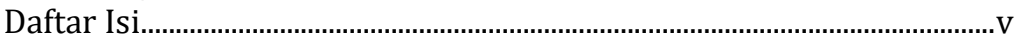

\section{BAB I}

AKSELERASI PEMBELAJARAN ....................................... 1

MELEJITKAN KECERDASAN EMOSIONAL MAHASISWA PASCA

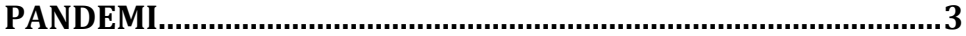

Dr. Rijal Firdaos, M.Pd. (Universitas Islam Negeri Sultan Maulana Hasanuddin Banten)

PERUBAHAN MINDSET GURU DALAM PENCAPAIAN HASIL BELAJAR PASCA PANDEMI COVID-19

Prof. Dr. Jonni Siahaan, M.Kes. (Dosen Universitas Cenderawasih Papua)

PERAN GENERASI Z DALAM MENGEMBANGKAN POTENSI

DIRI DAN SOSIAL DI MASA PANDEMI.................................... 19

Dr. Anita, S.S., M.Pd. (UIN Sultan Maulana Hasanuddin Banten)

MENGOPTIMALKAN LITERASI FISIK SISWA PASCA PANDEMI

Dr. Adi Sucipto, M.Kes. (Pascasarjana IKIP Budi Utomo)

MENINGKATKAN LITERASI MEMBACA DAN MENULIS PESERTA DIDIK DENGAN METODE K-W-L PADA PTMT PASCA PANDEMI COVID-19.

Mochammad Ronaldy Aji Saputra, S.Pd. (MAN Sumenep)

OPTIMALISASI PEMBELAJARAN BAHASA INGGRIS PADA PERTEMUAN TATAP MUKA TERBATAS

Dewi Sartika, S.Pd., M.Pd. (UNISKI Kayuagung)

PENTINGNYA SEBUAH INOVASI DALAM PERKEMBANGAN MODEL PEMBELAJARAN PASCA PANDEMI

Ani Kurniawati, M.Pd. (Universitas Garut)

RETURN SPIRIT BELAJAR MAHASISWA PASCA PANDEMIK 55

Dr. Yayat Suharyat (Universitas Islam “45” Bekasi) 
OPTIMALISASI PEMBELAJARAN TATAP MUKA TERBATAS DENGAN PENERAPAN MODEL PEMBELAJARAN FLIPPED CLASSROOM.

Diki Septiawan, S.Pd. (SMA Negeri 1 Subang Kab. Kuningan)

OPTIMALISASI PENGEMBANGAN DIRI SISWA DI TENGAH PANDEMI COVID-19 DENGAN MADING DIGITAL

Dintya Ayu Purika, M.Pd. (SMA Negeri 1 Parenggean)

\section{BAB II}

SISTEM MANAJEMEN PENDIDIKAN

PERAN KETERAMPILAN MANAJERIAL KEPALA SEKOLAH DALAM PENGELOLAAN PEMBELAJARAN PASCA PANDEMI .77 Dr. Karwanto, M.Pd. (Universitas Negeri Surabaya)

TRANSFORMASI DAN MASA DEPAN PENDIDIKAN INDONESIA PASCAPANDEMI COVID-19.

Dr. Abdul Malik Iskandar, S.Ag, M.Si. (Universitas Magerezky)

BLENDED LEARNING SEBAGAI SOLUSI PEMBELAJARAN

PASCA PANDEMI

Dr. Syarifuddin, M.Pd. (Universitas Sriwijaya)

PEMBELAJARAN MATEMATIKA BERORIENTASI BUDAYA: ALTERNATIF PEMBELAJARAN PASCA PANDEMI COVID-19

Dr. Wara Sabon Dominikus, M.Sc. (Universitas Nusa Cendana Kupang)

MEMBUMIKAN EKSISTENSI NILAI PENDIDIKAN MULTIKULTURAL PASCA PANDEMI COVID-19 DI LINGKUNGAN PONDOK PESANTREN

Abdul Khamid, M.Pd. (Institut Agama Islam Negeri Salatiga, Indonesia)

MANAJEMEN KELAS PADA MASA PANDEMI

Nurmalina, M.Pd. (IAIN Takengon)

PEMANFAATAN LMS CANVAS INSTRUCTURE UNTUK MENDUKUNG PEMECAHAN MASALAH PADA PEMBELAJARAN MATEMATIKA PASCA PANDEMI 123

Julia Noviani, M.Pd. (IAIN Takengon) 
UPAYA MENEKAN RESIKO LEARNING LOSS MELALUI PEMBELAJARAN TATAP MUKA TERBATAS

Dr. Sholihatul Hamidah Daulay, S.Ag., M.Hum. (Universitas Islam Negeri Sumatera Utara)

SERBA-SERBI PELAKSANAAN PEMBELAJARAN TATAP MUKA TERBATAS (PTMT)

Susana Labuem, M.Pd. (Universitas Pattimura PSDKU ARU)

IMPLEMENTASI GERAKAN SEKOLAH MENYENANGKAN (GSM) UNTUK MENUMBUHKAN KARAKTER DAN MINAT BELAJAR SISWA DALAM PERSIAPAN PEMBELAJARAN TATAP MUKA

Octa Prasetya Adi, M.Pd. (SMPS 1 Bumitama Antang Kalang

Yayasan Bumitama)

EFEKTIVITAS WAKTU PADA PEMBELAJARAN TATAP MUKA TERBATAS (TMT)

Dede Risma Ginanjar, S.Pd. (SD Aisyiyah Kota Sukabumi)

INTEGRASI NILAI MULTIKULTURAL DALAM PEMBELAJARAN PESANTREN PASCAPANDEMI .............................................157

Siyono, M.Pd.I. (IAIN Salatiga)

KONSEP PENGEMBANGAN "GURU MERDEKA BELAJAR" DI DALAM IMPLEMENTASI PEMBELAJARAN TATAP MUKA

TERBATAS

Ida Farida (SMKN 10 Medan)

STRATEGI GURU DALAM MENGHADAPI PEMBELAJARAN

PASCA PANDEMI DI SEKOLAH DASAR

Sofia G. Un Lala (Universitas Nusa Cendana)

\section{BAB III}

\section{LITERASI FISIK PENDIDIKAN JASMANI DAN}

OLAHRAGA ..............................................................177

PEMBELAJARAN BLENDED LEARNING PADA MATA KULIAH

PENJASKES DI IAIN MADURA..............................................179

Mutik Nur Fadhilah, M.Pd. (IAIN Madura)

PERKULIAHAN TEORI DAN PRAKTEK PENCAK SILAT II PASCAPANDEMI

Dr. Agus Mukholid, M.Pd. (Universitas Sebelas Maret Surakarta) 
PROGRAM LITERASI FISIK PADA MASA PEMBELAJARAN

TATAP MUKA TERBATAS BAGI SISWA

Yudo Harvianto, S.Pd., M.Pd. (Universitas Palangka Raya)

PELAKSANAAN PEMBELAJARAN PJOK DENGAN MENGGUNAKAN HYBRID LEARNING DI SMA NEGERI 4 MALANG.

Dony Andri Setiawan, M.Pd. (SMA Negeri 4 Malang)

PEMBELAJARAN TATAP MUKA TERBATAS PADA

PEMBELAJARAN PENDIDIKAN JASMANI, OLAHRAGA, DAN

KESEHATAN DI KOTA PALEMBANG 203

Destriana, M.Pd. (Universitas Sriwijaya)

MODEL PEMBELAJARAN SELF REGULATED DALAM

PENINGKATAN HASIL BELAJAR DALAM PEMBELAJARAN

PENJAS DI SEKOLAH KEJURUAN 209

Rini Andriani, S.Pd. (SMKN 10 Medan)

PERAN OLAHRAGA TRADISIONAL DALAM MEMBENTUK

PROFIL PELAJAR PANCASILA 215

Mia Kusumawati, M.Pd. (UNISMA Bekasi) 


\section{BAB I}

\section{AKSELERASI PEMBELAJARAN}

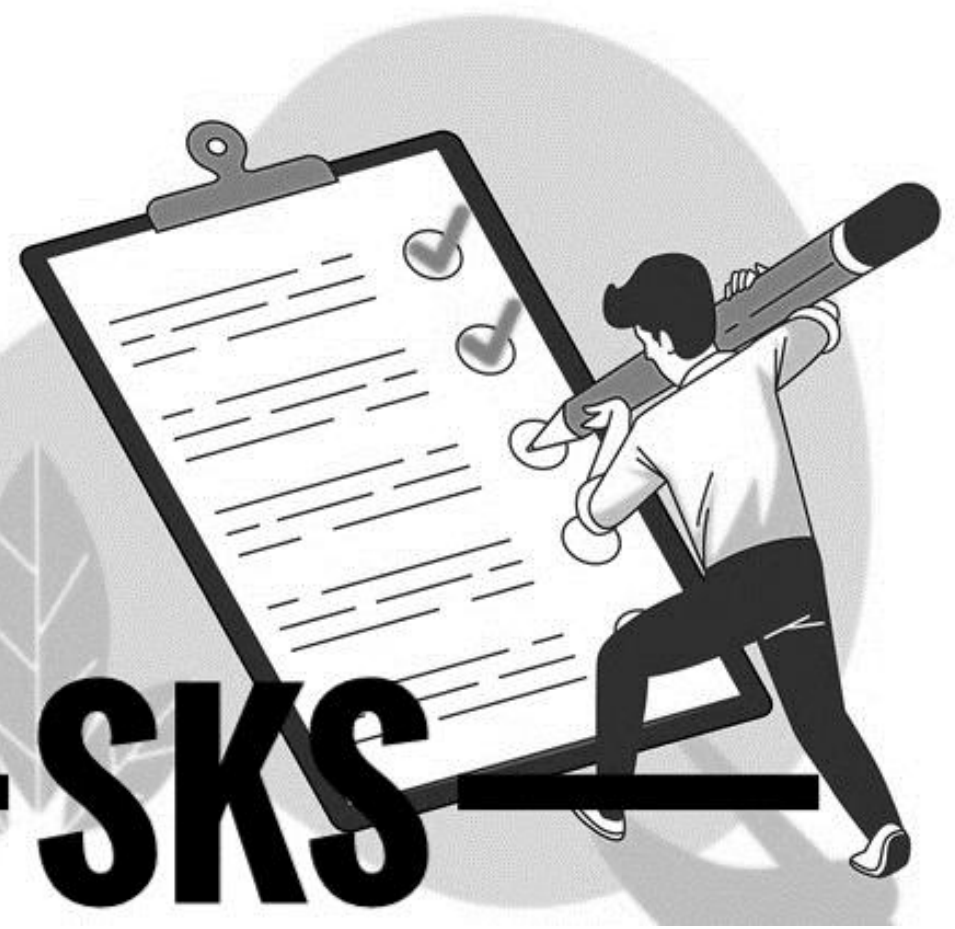




\title{
MELEJITKAN KECERDASAN EMOSIONAL MAHASISWA PASCA PANDEMI
}

\author{
Dr. Rijal Firdaos, M.Pd. ${ }^{1}$ \\ (Universitas Islam Negeri Sultan Maulana Hasanuddin Banten)
}

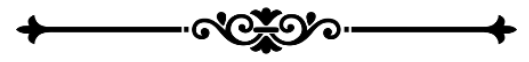

"Mahasiswa yang dapat melewati masa-masa pandemi dengan belajar berempati kepada sesamanya, dipercaya akan lebih mudah menjadi diri sendiri, tanpa harus mengadopsi jati diri orang lain"

\section{A. Studi Pendahuluan}

$\mathrm{M}$ anusia dalam perspektif Alquran memiliki arti; sebagai Basyar (fisiologis), Al-Insan (psikologis), dan Al-Nas (sosial). Jati diri manusia dikatakan sebagai Basyar (fisiologis) karena memiliki bentuk tubuh yang sempurna. Memiliki anggota tubuh yang dapat menjalankan aktivitas kehidupan sebagaimana yang diharapkannya. Pada konteks manusia sebagai Al-Insan (psikologis), Allah mempertegas kepada kita, bahwa manusia telah diberi bekal yang cukup dalam dirinya. Yaitu memiliki rasa, hati, nafsu, serta segala bentuk kehendak dan keinginan yang dapat menghantarkan seseorang pada mimpinya yang Ia bangun di bawah alam sadarnya. Adapun manusia dalam arti Al-Nas (makhluk sosial), merupakan

\footnotetext{
${ }^{1}$ Penulis lahir di Serang, 07 September 1982. Penulis merupakan Dosen di Universitas Islam Negeri Sultan Maulana Hasanuddin Banten. Penulis menyelesaikan gelar Sarjana Sastra di UIN Jakarta (2004), menyelesaikan gelar Magister Pendidikan di инамкA Jakarta (2006), dan menyelesaikan gelar Doktor di Universitas negeri Jakarta (2015).
} 
keniscayaan yang tidak dapat terbantahkan. Karenanya, manusia saling membutuhkan satu sama lain, serta tidak akan bisa hidup secara individual.

Tema melejitkan kecerdasan emosional mahasiswa pasca pandemi ini, sengaja saya angkat di tengah-tengah Covid-19 yang masih melanda, dengan beberapa catatan: Pertama, pandemi yang telah membatasi ruang gerak manusia, mengajarkan kepada kita betapa pentingnya manusia menahan diri untuk tidak melakukan sesuatu di luar kebiasaannya. Bahkan kita dipaksa untuk menahan diri untuk tidak berkumpul dengan orang banyak, kendati kegiatan tersebut merupakan tugas dan tanggung jawab kita sebagai karyawan misalnya, atau sebagai mahasiswa.

Kedua, pandemi telah malahirkan motivasi yang tinggi bagi para pekerja teknologi. Di mana, setelah sekolah dan Universitas melakukan kegiatan pembelajaran melalui daring (dalam jaringan), maka secara bersamaan lahirnya aplikasiaplikasi besutan pakar teknologi sebagai media pertemuan secara online. Munculnya ide-ide cemerlang seperti ini, harus diyakini menjadi salah satu hikmah di balik musibah pandemi. Ketiga, pandemi mengajarkan kita untuk menjadi manusia yang peduli terhadap sesama. Peduli dalam arti meningkatkan rasa kedermawanan kita kepda mereka yang membutuhkan. Karena kita tahu, Covid-19 telah banyak memakan korban jiwa, menyisakan banyak anak-anak yatim yang kehilangan orang tuanya. Bahkan, bukan hanya itu, tidak sedikt para pekerja/buruh yang juga kehilangan pekerjaannya akibat perusahaan yang tidak mampu membayar gaji bagi karyawannya.

Dari ketiga alasan di atas dapat diambil benang merahnya, bahwa secara psikologis, manusia dengan bekal kecerdasan emosionalnya, dapat hidup dalam kondisi apapun. Baik dalam kondisi normal, maupun dalam kondisi pandemi yang melanda dunia secara menyeluruh. 


\section{B. Penelitian Relevan}

Penelitian tentang kecerdasan emosional sudah banyak dilakukan oleh para peneliti sebelumnya. Baik yang berhubungan dengan hasil belajar, sikap sosial, spiritual, manajemen, model bimbingan, organisasi, kinerja, motivasi, upacara adat, pola asuh, kepuasan kerja, agresivitas remaja, kecemasan mahasiswa, serta masih banyak lagi studi yang menghubungkan langsung dengan variabel kecerdasan emosional. Ini membuktikan, bahwa kecerdasan emosional dapat memberikan pengaruh pada setiap lini kehidupan manusia. Di mana, dengan modal kecerdasan emosional yang baik, seseorang dapat menyesuaikan diri dengan lingkungannya, bahkan bisa lebih sukses melebihi orang yang memiliki kecerdasan intelektual yang tinggi.

\section{Pembahasan dan Diskusi}

Kecerdasan emosional diartikan sebagai kemampuan untuk mengenali, mengelola, dan mengekspresikan dengan tepat, termasuk untuk memotivasi diri sendiri, mengenali emosi orang lain, serta membina hubungan dengan orang lain. Akar kata emosi adalah movere, kata kerja bahasa Latin yang berarti 'menggerakan, bergerak', ditambah awalan 'e' untuk memberi arti 'bergerak menjauh', menyiratkan bahwa kecenderungan bertindak merupakan hal mutlak dalam emosi. Bahwasanya emosi memancing tindakan yang tidak rasional.

Kecerdasan Emosional dipopulerkan oleh Daniel Goleman dalam bukunya yang terkenal dengan " Emotional Intelligence". Ia mengatakan bahwa koordinasi suasana hati adalah inti dari hubungan sosial yang baik. Apabila seseorang pandai menyesuaikan diri dengan suasana hati individu yang lain atau dapat berempati, orang tersebut akan memiliki tingkat emosionalitas yang baik dan akan lebih mudah menyesuaikan diri dalam pergaulan sosial serta lingkungannya. 
Goleman memberikan lima indikator terkait dengan kecerdasan emosional. Yaitu: mengenali emosi diri, mengelola emosi diri, memotivasi diri, membina hubungan dengan orang lain, dan memahami emosi orang lain. Ke lima indikator tersebut menjadi pokok bahasan dalam kajian ini, sekaligus bagaimana melejitkan kecerdasan emosional mahasiswa pasca pandemi.

Pertama: Mahasiswa yang baik adalah mereka yang tidak hanya terdaftar secara formal di universitas, atau tidak sekedar menjadi mahasiswa yang kutu buku. Melainkan, mahasiswa yang baik adalah mereka yang mampu mengidentifikasi dirinya, potensinya, kemampuannya dalam bidang yang ia tekuni. Mengenali dirinya sebagai manusia yang syarat akan potensi nilai, termasuk langkah awal dalam melejitkan kecerdasan emosional. Dengan mengenali emosi diri, seseorang dapat menentukan arah mana tujuan hidup yang akan dicapai.

Kesadaran diri dalam mengenali perasaan sewaktu perasaan itu terjadi merupakan dasar kecerdasan emosional. Pada tahap ini diperlukan adanya pemantauan perasaan dari waktu ke waktu agar timbul wawasan psikologi dan pemahaman tentang diri. Ketidakmampuan untuk mencermati perasaan yang benar, membuat diri berada dalam kekuasaan perasaan. Sehingga tidak peka akan perasaan yang berakibat buruk bagi pengambilan keputusan masalah. Inti dari kecerdasan emosional adalah kesadaran akan perasaan diri sendiri sewaktu perasaan itu timbul, ciri kesadaran ini dilukiskan sebagai "perhatian tak memihak'. Kesadaran diri bukanlah perhatian yang larut ke dalam emosi, bereaksi secara berlebihan dan melebih-lebihkan apa yang diserap.

Kedua: Mengelola emosi berarti menangani perasaan agar perasaan dapat terungkap dengan tepat, hal ini merupakan kecakapan yang sangat bergantung pada kesadaran diri. Emosi dikatakan berhasil dikelola, apabila: Mampu menghibur diri ketika ditimpa kesedihan, dapat melepas 
kecemasan, kemurungan atau ketersinggungan dan bangkit kembali dengan cepat dari semua itu. Mengelola emosi di saat Pandemi bukanlah hal yang mudah, namun bukan pula hal yang mustahil. Sebab, dengan hadirnya perlakuan pembelajaran yang berbeda antara kondisi normal dengan kondisi pandemi, tentu dapat melatih seseorang agar dapat mengelola emosinya secara baik.

Mahasiswa yang memiliki Jiwa lemah akan selalu goyah dalam menghadapi suatu cobaan. Tidak punya pendirian dan mudah patah di tengah jalan. Kelemahan jiwa ini mudah dijangkit penyakit hati yang disebut dengan putus asa. Bila putus asa ini sudah bercokol dalam hati seseorang, ia akan memperlemah semangat hidupnya, lumpuh sebelum berjuang, takut terhadap kritik dan nasehat, juga dapat menimbulkan sikap apatis terhadap semua pekerjaan yang dilakukan. Akan tetapi, mahasiswa yang dapat mengontrol emosinya dengan stabil saat kondisi yang tidak normal, niscaya akan mudah menyesuaikan diri pada saat situasi normal.

Ketiga: Motivasi diri. Mahasisa yang memilik motivasi diri yang kuat saat bencana Covid-19 melanda, dipercaya dapat menjadikan seseorang tersebut tetap survive. Motivasi ibarat cahaya yang dapat menghantarkan pada jalan terang yang bersinar. Orang yang kehilangan barang tentu ia akan bersedih. Orang yang kehilangan keluarga yang ia cintai, pasti akan lebih sedih. Tapi orang yang kehilangan motivasi, maka dia akan kehilangan segala-galanya.

Motivasi akan membuahkan kesuksesan. Sukses berarti banyak hal yang mengagumkan dan positif, sukses berarti kesejahteraan pribadi: Rumah bagus, liburan, perjalanan, barang-barang baru dan kesempatan untuk maju. Sukses berarti memperoleh kehormatan, kepemimpinan, disegani, baik dalam bisnis maupun kehidupan sosial. Sukses berarti kebebasan. Bebas dari kegelisahan, ketakutan, kekecewaan (frustasi), dan kegagalan. Sukses berarati menang. Sukses- 
prestasi, mencapai tujuan-apakah tujuan hidup ini? Menjadikan diri kita sukses, yang tenang dan bahagia.

Keempat: Membina hubungan dengan orang lain. Seni dalam membina hubungan dengan orang lain merupakan keterampilan sosial yang mendukung keberhasilan dalam pergaulan dengan orang lain. Tanpa memiliki keterampilan, seseorang akan mengalami kesulitan dalam pergaulan sosial. Sesungguhnya karena tidak dimilikinya keterampilanketerampilan semacam inilah yang menyebabkan seseroang seringkali dianggap angkuh, mengganggu atau tidak berperasaan. Salah satu kunci kecakapan sosial adalah seberapa baik atau buruk seseorang mengungkapkan perasaannya sendiri (tata krama tampilan).

Dalam bersosialisasi hendaknya seorang mahasiswa mempunyai tampilan emosi yang baik. Karena kecerdasan emosional mencakup dalam menangani hubungan sosial dan dapat menularkan emosi positif. Seorang mahasiswa yang memiliki kemampuan menjalin hubungan baik dengan semua pihak di masa pandemi, akan lebih mudah meneruskan hubungan tersebut pasca pandemi. Sebab,

Kelima: Memahami emosi orang lain. Mahasiswa yang memiliki kemampuan mengenali emosi orang lain, akan cenderung memiliki pandangan yang positif dalam menilai segala sesuatu yang terjadi dalam dirinya. Akar permasalahan di sini adalah Empati (Empathia) yang artinya, adalah ikut merasakan bagaimana perasaan orang lain. Suatu kemampuan Empati dapat di tumbuhkan sejak bayi, dengan mulai belajar mensetarakan/menyelaraskan emosi.

Kemampuan seseorang mengenali emosi orang lain dapat pula ditelusuri melalui hal-hal sebagai berikut: a) cara mengendalikan dorongan hati; b) derajat kecemasan yang berpengaruh terhadap unjuk kerja seseorang; c) kekuatan berfikir positif; d) optimisme; dan e) keadaan flow (mengikuti aliran), yaitu keadaan ketika perhatian seseorang sepenuhnya tercurah ke dalam apa yang sedang terjadi, pekerjaannya 
hanya terfokus pada satu objek. Al hasil, mahasiswa yang dapat melewati masa-masa pandemi dengan belajar berempati kepada sesamanya, dipercaya akan lebih mudah menjadi diri sendiri, tanpa harus mengadopsi jati diri orang lain.

\section{Daftar Pustaka}

Firdaos, Rijal. Bersahabat dengan Tuhan. Bandar Lampung: Intan Media, 2011.

."Emotional Intelligence, Religiosity, and Social Attitude of Students." Jurnal Pendidikan Islam UIN Sunan Gunung Djati 3, no. 1 (2017): 45-56.

Goleman, Daniel. Emotional Intellegence, Jakarta: PT Gramedia Pustaka utama, 2004.

Mayer, John. Emotional Intelligence What The Research Says. USA: Edutional Leadership, 2000.

Suharsono. Akselerasi Intelegensi, Optimalkan IQ, EQ dan SQ. Jakarta: INISIASI PRESS, 2004. 


\title{
PERUBAHAN MINDSET GURU DALAM PENCAPAIAN HASIL BELAJAR PASCA PANDEMI COVID-19
}

\author{
Prof. Dr. Jonni Siahaan, M.Kes. ${ }^{2}$ \\ (Dosen Universitas Cenderawasih Papua)

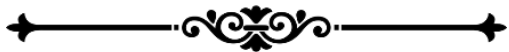

"Perubahan mindset guru membuat anak didik mengalami kesuksesan dalam meningkatan hasil belajar di pasca pandemi Covid-19"

\begin{abstract}
Sekolah dibuka kembali adalah kerinduan yang sangat $S_{\text {mendalam bagi para murid di semua jenjang pendidikan }}$ TK/PAUD/SD sampai SLTA bahkan Perguruan Tinggi, meskipun harus tetap mematuhi protokol tetap (Protap) kesehatan seperti selalu mencuci tangan dengan sabun/deterjen, atau sejenisnya, tetap pakai masker, tetap jaga jarak (social distancing), menjaga pola hidup sehat termasuk didalamnya pola makan yang sehat, rajin berolahraga agar tetap memiliki tubuh bugar dan sehat, imunitas tubuh tetap terjaga baik, istirahat yang cukup, dan lain-lain. Semua ini sudah menjadi kharakter/perilaku/kebiasaan yang wajib harus diwujudkan setiap insan manusia.
\end{abstract}

2 Penulis lahir di Martubung, Medan, 13 Nopember 1965. Penulis merupakan Guru Besar/Profesor dalam bidang Ilmu Pendidikan Olahraga di Universitas Cenderawasih Papua. Penulis menyelesaikan gelar Sarjana Pendidikan Kepelatihan di FPOK IKIP Medan. Menyelesaikan gelar Magister Gizi Masyarakat di Unair Surabaya (1999). Dan menyelesaikan gelar Doktor Pendidikan Olahraga di UNNES Semarang (2008). 
Apapun wujud protokol kesehatan yang diterapkan Pemerintah RI melalui gugus covid-19 nasional sebagai persyaratan untuk sekolah dibuka kembali sepertinya sudah tidak menjadi masalah dan semua murid dengan senang hati akan mematuhinya. Kerinduan murid kembali ke Sekolah dengan wajib mematuhi protap kesehatan membutuhkan perubahan mindset dimana tanpa disadari ada kebiasaan yang hilang ketika berinteraksi antar siswa dengan siswa, guru dengan guru, guru dengan Kepala Sekolah dan Wakil Kepala Sekolah, begitu juga dengan tenaga administrasi sekolah. Perubahan mindset tersebut terjadi di semua aktivitas baik saat bercengkrama, berjalan bersama, berdiskusi, dan aktivitas lainnya yang tetap pakai masker dan jaga jarak.

Perubahan mindset akan terjadi selama proses belajar berlangsung di dalam kelas atau dilapangan. Prinsipnya proses belajar mengalami perubahan baik dari aspek metode belajar, gaya mengajar, pengelolaan kelas, materi ajar termasuk capaian dari hasil belajar. Pada dasarnya mindset proses belajar berlangsung relatif berbeda dari sebelum pandemi, masa pandemi dan pasca pandemi. Kemajuan teknologi digital secara sadar dan tanpa sadar akan mengubah mindset guru guru dalam mengembangkan proses belajar baik di dalam maupun luar kelas atau di lapangan.

Kemajuan teknologi digital menjadi bagian yang tidak terpisahkan dalam proses belajar dan sebagai dampaknya muncul mindset baru bahwa diperlukan penggabungan pembelajaran daring (online) dengan tatap muka. Sebagai akibatnya muncul istilah Blended Learning atau Hybrid Learning. Istilah Blended learning diartikan sebagai sebuah metode atau model belajar yang menggabungkan, mencampurkan, mengombinasi sistem pembelajaran konvensional dengan berbasis digital. Blended learning juga diartikan sebagai pengabungan atau kombinasi pengajaran langsung (face to face) dan pengajaran online. 
Perubahan mindset berikutnya adalah istilah Hybrid learning adalah pembelajaran yang menggabungkan berbagai pendekatan yakni tatap muka, pembelajaran berbasis computer dan berbasis online (internet and mobile learning). Metode belajar seperti Blended learning dan Hybrid Learning memunculkan mindset baru untuk meningkatkan mutu pendidikan, olehkarena penyajian materi ajar menjadi lebih mudah dipahami dan mudah untuk menyampaikannya dan banyak materi ajar yang dapat dikuasai anak didik. Pendekatan belajar dengan kedua metode ini juga sangat baik digunakan untuk meningkatkan kompetensi seseorang.

Perubahan mindset guru menjadi kata kunci keberlangsungan proses belajar yang optimal dalam rangka mewujudkan hasil belajar yang optimal secara khusus di pasca pandemi covid-19. Kondisi riil murid ketika hendak memulai proses belajar offline pasca pandemi wajib harus diketahui para guru. Kehadiran siswa di sekolah dengan segala keterbatasan yang ada padanya wajib direspon dengan hati yang gembira. Setiap siswa berbeda kemampuannya, secara otomatis akan berdampak pada perbedaan hasil belajar yang diharapkan. Mindset guru yang harus dibangun adalah menciptakan proses belajar menyenangkan tanpa membeda-bedakan keterbatasan murid.

Perubahan mindset pada guru dapat diartikan bahwa guru memiliki berbagai pemikiran yang mendalam, asumsi, metode, dan ide/gagasan serta berkeyakinan dapat memengaruhi perilaku/kharakter/pola pikir anak didik dalam memulai perilakunya/sikapnya/pandangannya/ gagasannya untuk membangun dirinya, bangkit dari ketertinggalan dalam pelajaran dan mampu melihat masa depannya yang lebih baik. Semua perubahan yang sangat diharapkan terjadi pada anak didik tentu memunculkan keyakinan siswa akan berhasil menggapai masa depannya lebih baik.

Perubahan mindset pada guru secara otomatis akan mampu mengubah mindset anak didik dalam mengikuti 
proses belajar di sekolah maupun di rumah. Kesadaran akan pentingnya belajar sungguh-sungguh dengan memanfaatkan teknologi digital menjadi bagian tak terpisahkan dalam meningkatkan hasil belajar. Olehkarena proses belajar dapat diwujudkan dimana saja, kapan saja, bahkan di Mall-Mall, di tempat keramaian, di tempat rekreasi dan lain-lain.

Carol Dweck dalam bukunya Mindset Psychologist mengemukakan bahwa kesuksesan akan terjadi ketika seseorang memiliki mindset yang benar (right mindset) dari pada memiliki kecerdasan (intelligence), bakat dan pendidikan. Manusia percaya bahwa manusia dilahirkan ke dunia sudah memiliki kecerdasan, kemampuan masingmasing (fixed mindset). Pandangan Carol Dweck ini ingin menjelaskan bahwa potensi, bakat dan kemampuan/keahlian adalah bawaan lahir yang selanjutnya di asah, asuh, asih dengan mindset yang benar (growth mindset). Artinya mindset yang dimiliki harus bertumbuh menjadi lebih baik dan dapat mengikuti kemajuan zaman yang terus berkembang pesat.

Proses belajar di sekolah dan di rumah sebaiknya dapat mengembangkan fix mindset menjadi growth mindset. Dalam implementasinya, materi ajar yang disampaikan sebaiknya dapat mengembangkan potensi bawaan yang dimiliki anak didik. Dalam konteks ini sangat diharapkan para guru dapat meningkatkan ilmu pengetahauan, keterampilan dan kharakter anak didik, guru menjadi soko guru, sosok atau model yang ditiru atau model baik dalam berpikir, bertindak, maupun bersikap atau berprilaku, sehingga kelak menjadi anak bangsa yang berguna bagi dirinya, bagi bangsa dan negara Indonesia.

Fenomena atau fakta yang berkembang dewasa ini banyak anak didik yang memiliki perilaku yang kurang terpuji. Guru sepertinya bukanlah sosok yang harus di dengar. Jika guru mau menghukum murid karena perilaku murid yang kurang terpuji, harus berpikir berkali-kali karena belum tentu orangtua murid bisa menerimanya. Mindset orangtua murid sudah berubah. Mindset guru tidak boleh jauh dari perannya 
sebagai pengajar, mendidik, melatih, mengembangkan potensi bakatnya, dan lain-lain. Dalam konteks ini, mindset guru tentu dapat memberi hukuman pada murid jika benar-benar tidak taat aturan. Mindset guru dan murid harus seirama.

Dalam mewujudkan proses belajar yang baik di sekolah dan/atau di rumah pasca pandemi covid-19 ini sangat diharapkan diawali dengan mengubah mindset baik pada guru maupun siswa untuk mendisain dengan pendekatan yang berbeda dalam metode belajar dan gaya mengajar yang menyesuaikan dengan kondisi riil siswa dan siswa mampu memahami kemampuan dirinya yang sesungguhnya dan meyadari betapa perlunya menyiapkan waktu banyak untuk mengulangi materi peajaran di sekolah secara mandiri di rumah.

Salah satu parameter keberhasilan guru dalam proses belajar adalah bertumbuhnya pikiran (growth mindset) murid dalam proses belajar dimanapun berada. Belajar menjadi kebutuhan hidup sehari-harinya. Berusaha untuk belajar dengan tekun dan sadar akan pentingnya belajar sebagai upaya untuk memiliki pengetahuan, keterampilan (skill) dan pembentukan sikap dan perilaku yang berguna bagi kehidupannya. Bertumbuhnya pola pikiran yang benar tentu menjadi bekal hidup yang sangat berharga di masa depan anak didik.

Hipotesis yang berkembang bahwa proses belajar selama daring ini secara sadar dan tanpa sadar telah menurunkan mutu pendidikan anak didik. Mindset murid akan pentingnya belajar bagi dirinya bukan menjadi skala prioritas. Memang selama proses belajar daring ini, dalam penilaian hasil belajar siswa menjadi lebih mudah. Para guru lebih banyak membantu siswa dalam hal memberikan nilai, olehkarena lebih didasarkan pada pertimbangan tingkat kesulitan yang dialami siswa selama belajar daring antara lain disebabkan karena; sinyal wifi yang rendah bahkan mudah hilang, Hand Phone siswa yang kurang canggih dengan quota internet yang terbatas juga, sulitnya untuk bisa memperoleh feedback 
(umpan balik) langsung ketika dalam proses belajar ada halhal yang kurang jelas atau sulit dipahami anak didik dan lainlain.

Hasil pantauan penulis, proses belajar daring berlangsung selama 2 tahun belakangan ini, menunjukkan bahwa anak didik kurang serius belajar, kondisi ini tidak boleh terjadi dalam waktu yang lama, karena akan berdampak pada penurunan kualitas sumber daya manusia (SDM) dalam jangka panjang. Generasi muda Indonmesia yang hidup di era pandemi covid-19 besar peluangnya menjadi generasi yang kurang beruntung di masa akan datang karena berbagai kesempatan atau peluang yang seharusnya didapat selama belajar di sekolah, tidak diperolehnya, padahal sangat berguna untuk membangun potensi dirinya menjadi SDM unggul dimasa depan.

Kemajuan teknologi digital di satu sisi membutuhkan biaya tinggi, tetapi disisi lain anak didik dapat melakukan loncatan peningkatan kompetensinya jika menyadari pentingnya belajar secara mandiri. Sumber belajar yang tanpa batas, sesungguhnya sangat mungkin anak didik menguasai pengetahuan, keterampilan lebih tinggi dari tuntutan kurikulum. Sebaliknya murid yang tidak belajar optimal, dipastikan akan mengalami kemunduran dalam capaian hasil belajar. Olehkarena itu diperlukan perubahan mindset guru untuk bisa meyakinkan anak didik bahwa di era digital justru dapat terjadi peningkatan capaian hasil belajar melebihi target yang ditetapkan kurikulum sekolah.

Perubahan mindset yang dapat mengubah pola pikir siswa secara sadar menyiapan generasi muda Indonesia yang dapat bersaing secara kompetitif dimasa depannya. Perubahan mindset terus terjadi seiring dengan kemajuan teknologi digital, harus dapat disikapi murid sebagai bagian yang tak terpisahkan dalam hidupnya. Perubahan mindset harus menjadi kekuatan besar murid untuk mengembangkan potensinya dan Sekolah harus dapat menjadi jembatan untuk 
mengembangkan talent/bakat/potensi setiap anak didik yang berbeda-beda.

Pada hakekatnya mindset dapat juga diartikan sebagai cara seseorang menilai, dan/atau membuat suatu kesimpulan terhadap kajian, dan analisanya akan sesuatu kondisi yang dialaminya. Apabila diimplementasikan dalam proses belajar maka perubahan mindset menjadi mutlak adanya miliki anak didik. Sehubungan dengan ini maka mengembangkan mindset anak sejak usia dini melalui proses belajar sangat diperlukan agar kelak mampu menjadi anak bangsa yang tidak mudah terprovokasi dengan hal-hal yang kurang baik.

Carol Dweck dalam kajian motivasi, ada 7 mindset yang membuat seseorang berhasil dalam menjalani kehidupannya yaitu; 1) Ditch the Fixed Mindset (mengembangkan potensi/bakat bawaan lahir) 2). Go For Growth mindset (berkembang untuk bertumbuh potensi yang dimiliki). 3) An Abundance Mentality mindset (pola pikir yang menganggap semuanya serba melimpah dan karenanya semua kelimpahan yang kita miliki adalah potensi yang besar untuk memberi manfaat sebanyak-banyaknya kepada orang lain). 4) Not Scarcity Mentality mindset (menjauhkan diri dari pola pikir yang bermental miskin. Situasi pandemi menciptakan pemikiran hidup ini sulit, kebutuhan hidup kian tidak terpenuhi, kekurangan kebutuhan hidup, dan lain-lain). 5) Stop Fearing Failure mindset (berhenti pemikiran takut gagal). 6) Create a Long-Term Vision Instead of Only Short-Term Goals mindset (menciptakan visi misi jangka panjang bukan hanya tujuan jangka pendek). 7) Don't Be Afraid to Break the Rules (jangan takut melanggar aturan). 


\title{
PERAN GENERASI Z DALAM MENGEMBANGKAN POTENSI DIRI DAN SOSIAL DI MASA PANDEMI
}

\author{
Dr. Anita, S.S., M.Pd. ${ }^{3}$ \\ (UIN Sultan Maulana Hasanuddin Banten)

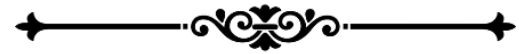

“Generasi Z yang memiliki karakteristik dengan dunia digital, berupaya untuk berperan dalam memberikan solusi terhadap permasalahan pendidikan di masa pandemi"

\begin{abstract}
Cenerasi $\mathrm{Z}$ adalah generasi dengan karakteristik mulai J mengenal media digital. Media digital hampir menjadi bahasa pertama mereka. Generasi ini adalah mereka yang terlahir dalam kurun waktu 1996-2010 (Articles et al., 2020). Berbeda dengan generasi sebelumnya, generasi $\mathrm{Z}$ terpapar dengan berita-berita tentang fashion, kuliner, hiburan dan liburan sehingga mereka menjadi bagian dari para pelaku didalamnya. Berbelanja produk dengan merek tertentu, mengkonsumsi makanan cepat saji, mendengarkan streaming musik pop Barat dan Indonesia serta berlibur bersama teman ataupun keluarga menjadi bagian dari gaya hidupnya. Dalam melakukan aktivitasnya, generasi ini banyak menggunakan media teknologi digital. Teknologi digital terintegrasi dengan sangat baik dalam kehidupan mereka. Generasi $\mathrm{Z}$ yang
\end{abstract}

\footnotetext{
${ }^{3}$ Penulis lahir di Pandeglang pada tanggal 10 April. Penulis merupakan Dosen pada program studi Tadris Bahasa Inggris di UIN Sultan Maulana Hasanuddin Banten. Penulis menyelesaikan gelar Sarjana di Fakultas Sastra Universitas Padjadjaran Bandung, sedangkan menyelesaikan gelar Magister dan Doktor Pendidikan Bahasa di Universitas Negeri Jakarta.
} 
terpapar oleh media digital mendapatkan pengalamanpengalaman dari membaca dan menyimak informasi mampu membuka wawasan yang memotivasi dan menumbuhkan keinginan untuk mendapat pengakuan secara lokal maupun global. Namun, tidak dapat dipungkiri bahwa generasi ini fokus akan dirinya, akan capaian-capaian yang diraihnya sesuai dengan bakat dan bidang yang diminatinya. Sebagaimana diungkapkan oleh Nicholas bahwa kebiasaan belajar secara intrapersonal pada generasi $\mathrm{Z}$ lebih mendominasi dibandingkan interpersonalnya (Articles et al., 2020). Namun tentunya generasi $\mathrm{Z}$ dengan kondisi selfsearched dalam memenuhi keingintahuannya dapat diarahkan dan difasilitasi dengan dukungan dan bimbingan untuk menjadi generasi yang mampu mengembangkan potensi diri untuk menjadi generasi tangguh dan andal.

Di masa pandemi covid-19, generasi $\mathrm{Z}$ yang lahir pada tahun 2000 an termasuk yang terkena dampaknya, mereka mengalami transisi dari proses pembelajaran secara offline menjadi online. Pembelajaran yang sebelumnya dilakukan di sekolah atau di kampus menjadi pembelajaran jarak jauh yang dilakukan secara online. Anak-anak tidak belajar di dalam kelas melainkan belajar dari rumah melalui media teknologi. Keluarga yang sebelum masa pandemi ditinggalkan anak-anak untuk menuntut ilmu di kota lain menjadi tempat yang menyediakan ruang untuk masing-masing anak melaksanakan pembelajaran secara online. Perubahan ini menjadikanya terpapar akan permasalahan yang ada di tempat ia tinggal. Para orang tua berubah peran, menjadi figur tempat berdiskusi dan pembimbing yang mengarahkan anak dalam menjalankan tugas-tugas yang diberikan guru maupun dosen secara online. Kedekatan antara anak dan orang tua secara otomatis terjalin sangat erat meskipun melalui proses penyesuaian yang ekstra karena orang tua dihadapkan dengan generasi yang terekspos dengan informasi sehingga diperlukan gaya mendidik yang memfasilitasi keingintahuan yang tidak mendikte. Kombinasi dan kolaborasi yang pas 
antara keinginan orang tua serta keinginan dan kebutuhan anak dapat menciptakan raihan-raihan pembelajaran yang optimal. Orang tua menempatkan target capaian sesuai dengan kondisi dan kemampuan anak. Orang tua mengayomi dan menempatkan diri sebagai partner dalam belajar.

Berkaitan dengan diperlukannya dukungan orang tua dan masyarakat dalam mengarahkan generasi $\mathrm{Z}$ untuk menjadi generasi harapan bangsa, perkenankan penulis men-share pengamatannya. Sebagaimana diketahui bahwa Maret 2020 merupakan awal pandemi covid mencuat di Indonesia saat Presiden Indonesia untuk pertama kalinya mengumumkan masuknya virus ke Indonesia (https://mediaindonesia.com/humaniora/387702/). Pada Bulan Maret pula para pelajar dipulangkan oleh pihak kampus dan pihak sekolah untuk melaksanakan pembelajaran jarak jauh, dari rumah secara online. Pembelajaran online yang dilakukan bukan tanpa kendala, khususnya bagi siswa-siswa yang tinggal di desa dan tidak memiliki android sebagai sarana pembelajaran online. Guru kebingungan mencari cara yang tepat dalam menyampaikan materi untuk mencapai target yang tercatat dalam kurikulum. Anak-anak sekolah dasar yang biasanya bersemangat berangkat ke sekolah menjadi kehilangan moment penting. Mereka tidak lagi bangun pagi untuk berangkat ke sekolah bersama temantemannya dan para guru tidak dapat mengekspresikan perhatian dan kepedulian terhadap peserta didik serta kebahagiaannya menyaksikan tumbuh kembang mereka. Para orang tua kehilangan kendali dalam memberikan motivasi agar anak bangun pagi dan mempersiapkan diri untuk belajar secara online. Guru dan siswa mengalami masa sulit untuk beradaptasi dengan pembelajaran mode online. Di sisi lain pemerintah melakukan berbagai upaya sebagai bentuk tanggung jawab untuk keberlangsungan pembelajaran tingkat dasar hingga perguruan tinggi. Penghapusan ujian nasional, perubahan regulasi sistem penerimaan siswa baru hingga pemberian kuota gratis untuk dapat mengakses internet 
sebagai fasilitas dalam pembelajaran. Tetapi tidak dapat dipungkiri bahwa kendala terbesar dari pembelajaran secara online adalah bagaimana membangun dan menjaga keterlibatan siswa dalam proses pembelajaran.

Lalu apa peran generasi $\mathrm{Z}$ dalam permasalahan pembelajaran di atas. Generasi $\mathrm{Z}$ yang duduk dibangku perkuliahan yaitu beberapa mahasiswa, atas dukungan masyarakat sekitar, membentuk komunitas taman baca "Bilik Urang" di Pandeglang. Komunitas taman baca ini terdiri dari para mahasiswa yang menjadi relawan pengajar dan anakanak dengan rentang usia 5-12 tahun. Dalam pengamatan penulis, mereka tidak hanya dituntut untuk menjadi pelajar yang fokus pada dirinya sendiri tetapi juga memiliki keputusan mengatur dirinya dengan cara belajar sebelum berbagi dengan orang lain. Didasari oleh kepedulian terhadap kondisi anak-anak sekolah usia dini dan anak-anak sekolah dasar yang pada masa pandemi terlihat bermain pada saat jam sekolah, maka para mahasiswa yang tergabung dalam komunitas Bilik Urang membuat program pendampingan kepada anak-anak untuk memahami literasi. Kegiatan pendampingan ini dilakukan sekali dalam seminggu yakni setiap hari Ahad. Setiap anggota secara bergilir bertugas membuat rencana pembelajaran untuk dijadikan acuan kegiatan. Rencana pembelajaran ini didiskusikan setiap malam Ahad sehingga pada saat bertemu dengan anak-anak, anggota komunitas ini telah siap dengan aktivitas yang akan diberikan kepada anak-anak dengan tetap melaksanakan protokol pencegahan covid-19. Komunitas ini bergerak atas dasar suka rela agar anak-anak tetap belajar memahami huruf dan angka sehingga mampu mengenal literasi, huruf dan angka, membaca dan menulis. Dijelaskan dalam sebuah artikel hasil penelitian bahwa more than 1300 students from 50 institutions, the Generation Z Stories Project, students shared examples of how their generation plans to change the world by solving complex problem (Seemiller \& Grace, 2017). Dalam hal ini, para mahasiswa yang terlibat dalam komunitas 
relawan "Bilik Urang" adalah generasi Z yang berupaya untuk berperan dalam memberikan solusi terhadap permasalahan pendidikan.

\section{Daftar Pustaka}

Articles, S., Nicholas, A. J., \& Nicholas, A. J. (2020). Digital Commons @ Salve Regina Preferred Learning Methods of Generation Z Preferred Learning Methods of Generation Z.

Seemiller, C., \& Grace, M. (2017). Generation Z: Educating and Engaging the Next Generation of Students. About Campus: Enriching the Student Learning Experience, 22(3), 21-26. https://doi.org/10.1002/abc.21293

(https://mediaindonesia.com/humaniora/387702/) 


\title{
MENGOPTIMALKAN LITERASI FISIK SISWA PASCA PANDEMI
}

\author{
Dr. Adi Sucipto, M.Kes. ${ }^{4}$ \\ (Pascasarjana IKIP Budi Utomo)

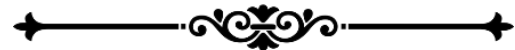

"Memasyarakatkan literasi fisik di sebuah negara diperlukan kebijakan pemerintah dan keterlibatkan semua pihak untuk mendorong tercapainya penguasaan literasi fisik anak-anak"

\section{A. Pendahuluan}

Di negara-negara maju, seperti Canada, Amerika, Australia literasi fisik sudah berkembang cukup lama. Namun di Indonesia baru dipublikasikan dalam beberapa tahun terakhir, sehingga banyak guru PJOK belum banyak yang mengenal apa itu literasi fisik. Sementara, di Canada, Amerika, Australia literasi fisik telah digunakan sebagai ideologi pemandu untuk pendidikan jasmani yang berkualitas di sekolah-sekolah dan masyarakat. Bahkan literasi fisik sudah digunakan sebagai dasar membangun prestasi olahraga jangka panjang melalui Long Term Athletic Development (LTAD).

Pengembangan Literasi fisik (physical Literacy) berawal ada kerisauan pemerintah Canada terhadap rendahnya

\footnotetext{
${ }^{4}$ Penulis lahir di Banyuwangi. Penulis merupakan Dosen Program Studi Magister Pendidikan Olahraga Pascasarjana IKIP Budi Utomo Malang. Penulis menyelesaikan gelar Sarjana Kepelatihan Olahraga di IKIP Negeri Surabaya (1990), kemudian menyelesaikan gelar Magister Ilmu Kesehatan Olahraga di Universitas Airlangga (1996). Dan menyelesaikan gelar Doktor Ilmu Keolahragaan (sport science) di Universitas Negeri Surabaya (2016).
} 
tingkat aktivitas fisik, hanya $7 \%$ dari anak-anak yang mendapatkan cukup berolahraga setiap hari, dan rata-rata menghabiskan enam jam sehari di depan layar (https://physicalliteracy.ca/).

\section{B. Definisi Literasi Fisik}

Sebagaimana dipaparkan oleh Whitehead (2016) Physical Literacy is the motivation, confidence, physical competence, knowledge and understanding to value and take responsibility for engagement in physical activities. Literasi fisik adalah motivasi, kepercayaan diri, kompetensi fisik, pengetahuan dan pemahaman menghargai dan mengambil tanggung jawab untuk terlibat dalam aktivitas fisik. Sedangkan definisi dari IPLA (International Physical Literacy Association): Literasi fisik adalah motivasi, kepercayaan diri, kompetensi fisik, pengetahuan, dan pemahaman untuk menghargai dan bertanggung jawab atas keterlibatan dalam aktivitas fisik seumur hidup (IPLA, 2014). Selain itu literasi fisik berhubungan gaya hidup aktif yang kompeten secara fisik sebagaimana diungkapkan oleh Durden-Myers, \& Keegan, (2019) Literasi fisik mengacu pada kapasitas individu untuk mempertahankan gaya hidup aktif secara fisik.

\section{Unsur-unsur Literasi Fisik}

Berdasarkan beberapa definisi literasi fisik yang telah dipaparkan di depan, literasi fisik mengandung unsur-unsur berikut: 1). Motivasi dan keyakinan (afektif); 2) kompetensi fisik (fisik); (3) Pengetahuan dan pemahaman (kognitif); 4) Keterlibatan aktivitas fisik untuk kehidupan (perilaku). Berikut gambar 1.2. Ilustrasi pengembangan standar literasi fisik (Darla M. Castelli, 2014). 


\section{Physical Literacy}

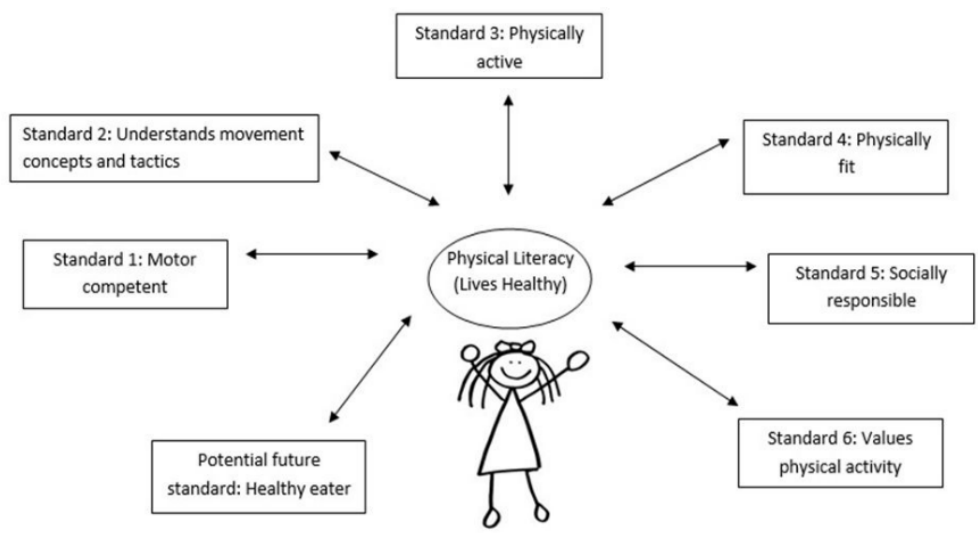

Gambar 01. Quality Physical Education: Past Practice \& Future Directions (USA) (Darla M. Castelli, 2014).

Individu yang melek fisik, akan selalu mempertahankan kondisi tubuh agar dapat menyesuaikan dengan kebutuhan fisik di lingkungannya. Hal ini senada dengan Higgs et al., (2008) Literasi fisik juga mencakup kemampuan untuk "membaca" apa yang terjadi di sekitar kita untuk bereaksi secara tepat terhadap peristiwa tersebut. Sehingga literasi fisik ini membawa kesadaran manusia untuk terus bergerak sapanjang hayat, mulai lahir sampai meninggal.

\section{Pendekatan Literasi Fisik (Physical Literacy Approach)}

Sebagaimana hasil penelitian yang dipelopori University of Canberra Research Institute for Sport and Exercise (UCRISE) ada 4 pendekatan pendidikan Jasmani dan literasi fisik yaitu: 1. Iklim Sekolah PEPL (The PEPL school climate; 2. Penyampaian kurikulum HPE (The delivery of the HPE curriculum); 3. Peluang Literasi fisik siswa (Student physical literacy opportunities); 4. Hubungan Sekolah-masyarakat 
(School-community links). Tanggungjawab Literasi Fisik (Physical Literacy Responsibilities)

\section{Who is Responsible for Teaching Physical Literacy?}

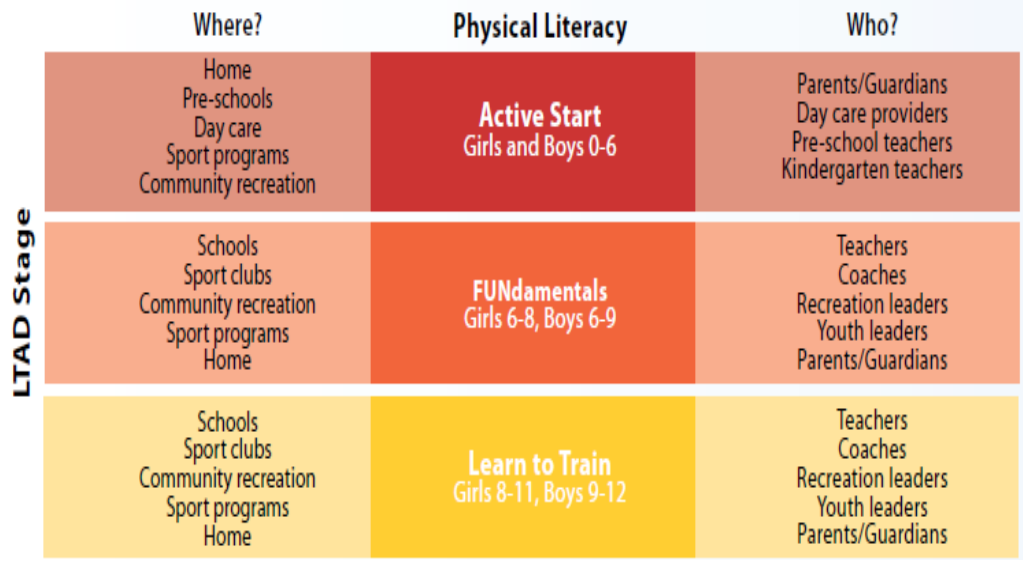

Gambar 02. Who Is Responsible For Physical Literacy? (Developing Physical Literacy: A Guide For Parents Of Children Ages 0 to 12)

Tanggungjawab guru pendidikan Jasmani terhadap pengembangan literasi fisik sebagaimana diunkapkan oleh Silverman, \& Mercier, (2015) Guru pendidikan jasmani memainkan peran penting dalam membantu pengembangan keterampilan motorik siswa yang diperlukan untuk menjadi individu yang melek fisik.

\section{Pendidikan Jasmani, Literasi Fisik Aktivitas Fisik}

Pendidikan jasmani mengembangkan individu yang melek fisik melalui praktik pendidikan jasmani. Selama pendidikan jasmani, siswa mempraktikkan pengetahuan dan keterampilan yang telah mereka pelajari melalui aktivitas fisik (SHAPE America, 2014). Ada beberapa perbedaan antara pendidikan jasmani dan literasi fisik yaitu: 1) Nama: Literasi fisik adalah konsep menyeluruh tentang prinsip-prinsip yg memandu praktik pendidikan jasmani, pendidikan jasmani 
(sebuah nama pelajaran); 2) Waktu: Literasai fisik adalah konsep kursus kehidupan dari lahir hingga meninggal (sepanjang hayat), sedangkan pendidikan jasmani terbatas waktu di Sekolah; 3) Filosofi: Literasi fisik memiliki landasan filosofis dan konseptual (monisme, eksistensialisme dan fenomenologi), sedangkan pendidikan jasmani tidak memiliki landasan filosofis yang jelas (masih perlu diskusikan) (https://www. pescholar.com).

Ada kedekatan hubungan antara literasi fisik dan pendidikan jasmani, seperti disampaikan Lundvall (2015) Literasi fisik bagian dari pendidikan jasmani karena filosofi literasi fisik adalah tujuan pendidikan jasmani, dan outcame dari pendidikan jasmani. Sedangkan Pendidikan Jasmani adalah mata pelajaran kurikuler sekolah yang mendukung pengembangan keterampilan, pengetahuan, dan sikap yang diperlukan untuk berpartisipasi dalam hidup aktif dan sehat. Program pendidikan jasmani merupakan komponen integral dari total pengalaman sekolah bagi siswa (PHE Canada).

\section{Literasi Fisik dan Prestasi Olahraga}

Development model (LTAD) mengakui literasi fisik sebagai dasar untuk mengembangkan keterampilan, pengetahuan, dan sikap yang dibutuhkan warga Canada untuk menjalani hidup aktif yang sehat. LTAD mendefinisikan literasi fisik sebagai: “...pengembangan keterampilan gerakan dasar dan keterampilan olahraga dasar (Fundamental movement skills/ FMS) and Fundamental Sport skills/ FSS) memungkinkan seorang anak untuk bergerak dengan percaya diri dan terkendali, dalam berbagai aktivitas fisik, ritme (menari) dan situasi olahraga.

Anak yang melek fisik, akan tanggap dan cepat merespon peristiwa-peristiwa yang terjadi di sekelilingnya. Mampu "membaca" apa yang terjadi di sekitar mereka dalam melakukan aktivitas dan bereaksi secara tepat terhadap peristiwa tersebut" (Higgs et al., 2008: 5). Pengembangan literasi fisik menuju atlet elit, dibagi menjadi beberapa fase: 
Diawali dengan pengembangan keterampilan gerak dasar (Fundamental Movement Skill/ FMS) dan keterampilan olahraga dasar (Fundamenta Sport Skill/ FSS) sampai pada pengembangan atlet elit.

\section{Pelaksanaan Literasi Fisik}

Sebagai upaya mengefektifkan literasi fisik di sekolah adalah dengan mendorong dan melatih para guru PJOK memahami literasi fisik, sebagaimana diungkapkan oleh Durden-Myers, dan Keegan, (2019) Pengembangan profesional yang efektif dan responsif bagi guru sangat penting jika anak-anak ingin menjadi lebih aktif secara fisik sepanjang hidup mereka. Peran guru PJOK sangat penting, bahkan dapat menjadi kunci keberhasilan literasi fisik di Sekolah. Ia bertanggungjawab atas terlaksananya pendidikan jasmani yang efektif, sehingga aktivitas fisik anak memenuhi standar baik. Hal ini seperti pandangan Silverman, \& Mercier, (2015) keputusan guru pendidikan jasmani berkontribusi pada pembelajaran siswa dan apakah tujuan literasi fisik terpenuhi.

\section{Implementasi Literasi Fisik di Sekolah}

Lembaga Sportaus Australia telah membuat panduan literasi fisik di Sekolah: Panduan literasi fisik tersebut dikelompok menjadi 3 adalah: 1) Culture, organisation and environment (Leadership, Policy, Environment) 2) Qurriculum, teaching and learning (Quality Health and Physical Education Program, Inclusive Co-Curricular Program, Cross Curricular Approach); 3) Partnerships (Families and local community). Implementasi literasi fisik dimulai dengan pengembangan keterampilan gerak dasar (Fundamental Movement Skill/ FMS) dan keterampilan olahraga dasar (Fundamental Sport Skill/ FSS). Keterampilan gerak dasar meliputi fine motor skill dan gross motor skill. Berikut klasifikasi gerak dasar (Fundamental Movement Skill FMS). 


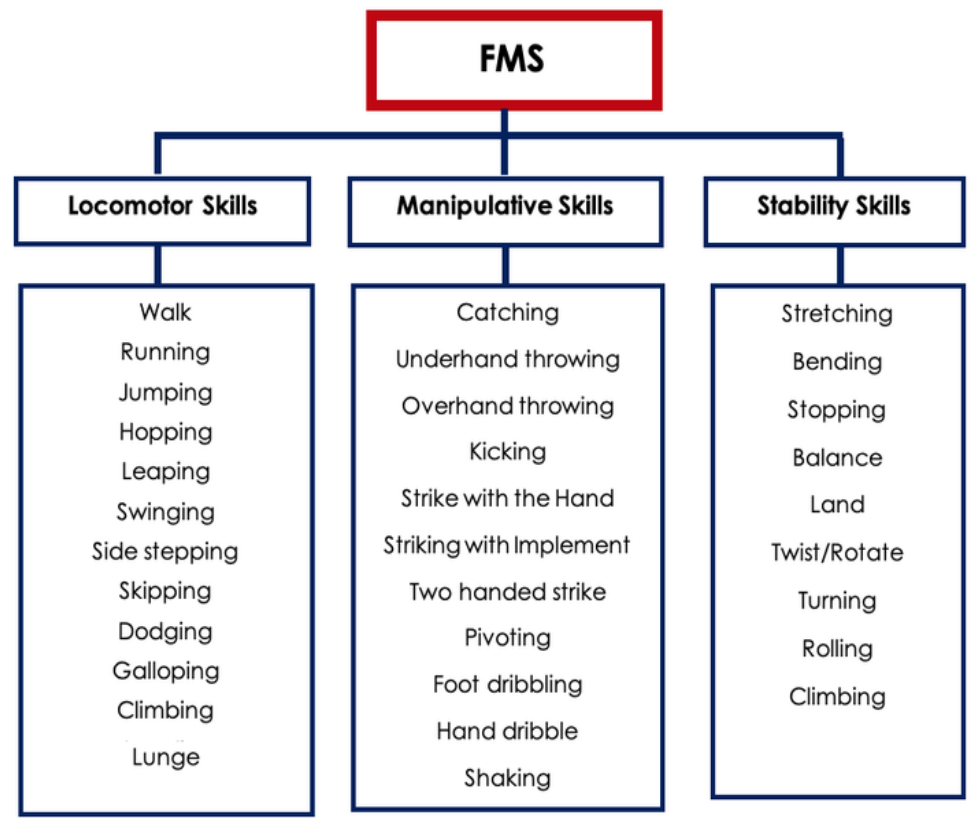

Tabel 03. Klasifikasi keterampilan gerak dasar (Fundamental Movement Skill) (Rainer, P. and Jarvis, S: 2020).

\section{Kesimpulan}

Memasyarakatkan literasi fisik di sebuah negara diperlukan kebijakan pemerintah dan keterlibatkan semua pihak. Pemerintah perlu menetapkan literasi fisik masuk menjadi bagian isi kurikulum pendidikan nasional. Dalam pengembangan atlet nasional pemerintah harus mensinkronkan tahapan pengembangan literasi fisik kedalam Desain Besar Olahraga Nasional (DBON) Menuju Indonesia Maju. Selanjutnya keterlibatan semua pihak diperlukan untuk mendorong tercapainya penguasaan literasi fisik anak-anak yaitu orangtua, kepala sekolah, para guru, dan pemuka masyarakat. 


\section{Daftar Pustaka}

Canadian Sport Centres. (2008). Canadian Sport for Life: Long Term Athlete Development resource paper v2. Canadian Sport Centres, Vancouver, BC

Durden-Myers, Elizabeth J. \& Keegan, Sarah. (2019). Physical Literacy and Teacher Professional Development. Journal of Physical Education, Recreation \& Dance. 90 (5), 3035. https://doi.org/10.1080/07303084.2019.1580636

Ennis, Catherine D. (2015). Knowledge, transfer, and innovation in physical literacy curricula. Journal of Sport and Health Science. 4(2), 119-124. http://dx.doi.org/10.1016/j.jshs.2015.03.001

Hayden-Davies, D. (2008). So what is physical literacy (and what use is it?). Paper presented at British Educational Research Association annual conference (September 4th). University of Edinburgh.

Higgs, C., Balyi, I., Way, R., Cardinal, C., Norris, S., Bluechardt, M. (2008). Developing physical literacy: A guide for parents of children ages 0 to 12.: Canadian Sport Centres, Vancouver, BC.

Higgs, C. et al (2019). Developing Physical Literacy: Building a New Normal for all Canadians, Copyright(C) Sport for Life Society. All rights reserved

Pot, N., Durden-Myers, E.J, \& Whitehead, M.E. (2018). Physical Literacy From Philosophy to Practice. Journal of Teaching in Physical Education, 37 (3), 246-251.

Rainer, P. and Jarvis, S. (2020). Fundamental Movement Skills: Are they a "Fundamental" part of a young child's Physical Education? https://bit.ly/3DEWbbe.

Silverman., \& Mercier, K. (2015). Teaching for physical literacy: Implications to instructional design and PETE. Journal of Sport and Health Science. 4(2), 150-155. https://doi.org/10.1016/j.jshs.2015.03.003. 


\title{
MENINGKATKAN LITERASI MEMBACA DAN MENULIS PESERTA DIDIK DENGAN METODE K-W-L PADA PTMT PASCA PANDEMI COVID-19
}

\author{
Mochammad Ronaldy Aji Saputra, S.Pd. ${ }^{5}$ \\ (MAN Sumenep)

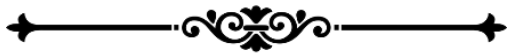

"Metode pembelajaran K-W-L pada PTMT Pasca Pandemi Covid-19 dapat memberikan peningkatan dan pengaruh yang positif terhadap literasi membaca dan menulis untuk mencapai tujuan; mengembangkan pemahaman dan potensinya melalui evaluasi pembelajaran"

\begin{abstract}
Dandemi Covid-19 telah merubah pola kehidupan serba Perbasis teknologi digital. Perubahan tersebut menjadikan sebuah tantangan yang besar dalam dunia literasi sehingga fasilitas yang tersedia harus bisa dimanfaatkan dengan inovatif, kreatif, komunikatif dan produktif oleh generasi muda (Sumarti et al, 2020). Tantangan selanjutnya dalam dunia literasi pada masa pandemi Covid-19 adalah guru dan orang tua tidak dapat sepenuhnya mengontrol belajar anak di rumah, serta buku-buku untuk bahan bacaan peserta didik di rumah masih kurang karena sekolah hanya memberikan pinjaman berupa buku tema saja (Subakti et al, 2021).
\end{abstract}

${ }^{5}$ Penulis lahir di Sidoarjo, 14 Januari 1995, penulis merupakan Guru Sejarah MAN Sumenep. Penulis menyelesaikan gelar Sarjana Pendidikan Sejarah di Universitas Negeri Malang (2017). 
Kondisi pendidikan di Indonesia mengenai tingkat literasi serta kemampuan berpikir kritis masih kurang selaras. Kurang selarasnya tingkat literasi dan kemampuan berpikir kritis menurut Anisa, dkk (2021) dikarenakan dari hasil survey UNESCO yang mengatakan bahwa minat membaca masyarakat Indonesia masih rendah. Kurangnya minat membaca menyebabkan tingkat literasi dan kemampuan berpikir kritis masih rendah. Kemudian menurut Solihin dkk (2019): 7) terdapat 3 faktor yang menghambat lajunya gerakan literasi, yaitu (1) minimnya akses di sekolah, (2) minimnya akses di masyarakat, serta (3) rendahnya perilaku membaca dibandingkan dengan mengakses media lainnya.

Pada bulan Agustus hingga November pada tahun 2021 pandemi Covid-19 telah mengalami penurunan. Berdasarkan data Satgas Covid-19 (2021) perkembangan kasus terkonfirmasi positif Covid-19 telah mengalami penurunan sejak bulan Agustus sebanyak 30.738 sampai November sebanyak 403. Dengan adanya penurunan kasus Covid-19 menjadikan kegiatan pelaksanaan tatap muka terbatas (PTMT) akan dilakukan di sekolah.

Kegiatan PTMT memberikan kesempatan peserta didik untuk merasakan kegiatan belajar secara tatap muka dengan guru. Dalam kegiatan tatap muka, guru dapat melakukan kreativitas pembelajaran dengan mendampinginya secara langsung. Dengan adanya pendampingan secara maksimal maka tingkat literasi membaca peserta didik dapat ditingkatkan. Salah satu metode untuk meningkatkan literasi membaca adalah metode K-W-L (Know, Want to Learn \& Learned). Beberapa penelitian seperti yang dilakukan oleh Usman, dkk (2019) dan Hilmi dkk (2019) menunjukan bahwa metode ini sangat efektif untuk meningkatkan minat baca peserta didik. Kemudian metode ini menurut penelitian Budianti \& Damayanti (2017) memberikan pengaruh yang positif terhadap keterampilan membaca dan minat baca peserta didik. 


\section{Metode K-W-L (Know, Want to Learn \& Learned)}

Metode K-W-L (Know, Want to Learn \& Learned) merupakan metode pembelajaran yang berpusat kepada peserta didik dengan menekankan tingkat pemahaman peserta didik dalam membaca sebuah informasi. Dalam metode ini terdapat 3 tahapan agar peserta didik dapat memahami sebuah informasi, yaitu (1) Know yaitu mengetahui apa yang dibaca oleh peserta didik, (2) Want to Learn, yaitu apa yang ingin diketahui oleh peserta didik setelah membaca dan (3) Learned, yaitu mempelajari apa yang ingin diketahui setelah membaca.

Metode K-W-L menurut Sani (2014: 274) sebaiknya memperhatikan beberapa langkah dalam membaca, yaitu (1) membimbing peserta didik menyampaikan ide-ide tentang topik bacaan yang akan dibaca, (2) mencatat ide-ide peserta didik tentang topik yang akan dibaca, (3) mengatur kegiatan diskusi terkait ide-ide yang diajukan peserta didik penyelesaian contoh mengelompokan ide. Prosedur untuk menerapkan metode $\mathrm{K}-\mathrm{W}$-L sebagai berikut:

1. Memberikan bacaan-bacaan yang akan dikupas

2. Menunjukan tabel K-W-L dan memberikan petunjuk pengisian tabel K-W-L

3. Menunjukan cara mengisi tabel $\mathrm{K}-\mathrm{W}-\mathrm{L}$ berdasarkan bacaan yang akan dikupas

a. Kolom K (Know) diisi dengan informasi yang telah diketahui oleh peserta didik dari bacaan yang telah dibaca.

b. Kolom W (Want to Learn) diisi dengan informasi yang ingin diketahui dari peserta didik. Pada kolom ini peserta didik diarahkan untuk membuat pertanyaan tentang isi teks bacaan yang telah dibaca.

c. Kolom L (Learned) diisi dengan informasi yang telah diketahui/menjawab pertanyaan dari kolom W (Want to Learn). 
Tabel 1. Contoh Tabel K-W-L Membahas Teks Sejarah Berdirinya Kerajaan Majapahit

\begin{tabular}{|c|c|c|}
\hline $\mathrm{K}($ Know $)$ & $\mathrm{W}$ (Want to Learn) & L (Learned) \\
\hline $\begin{array}{l}\text { Kerajaan } \\
\text { Majapahit berdiri } \\
\text { tahun (1293) } \\
\text { setelah Kerajaan } \\
\text { Singhasari } \\
\text { diserang oleh } \\
\text { Gelang-Gelang } \\
\text { (1292). }\end{array}$ & $\begin{array}{l}\text { Bagaimana proses } \\
\text { berdirinya Kerajaan } \\
\text { Majapahit? }\end{array}$ & $\begin{array}{l}\text { Berdirinya kerajaan } \\
\text { Majapahit berawal ketika } \\
\text { Raden Wijaya diberi } \\
\text { pengampunan oleh } \\
\text { Jayakatwang (Raja Gelang } \\
\text { Gelang) atas bantuan Arya } \\
\text { Wiraraja sehingga } \\
\text { diberikan wilayah Tarik. } \\
\text { Di Hutan Tarik, R. Wijaya } \\
\text { bersama pasukannya } \\
\text { memakan buah maja yang } \\
\text { rasanya pahit dan wilayah } \\
\text { tersebut dinamakan } \\
\text { Majapahit. }\end{array}$ \\
\hline $\begin{array}{l}\text { Raja terakhir dari } \\
\text { Kerajaan } \\
\text { Singhasari pada } \\
\text { waktu itu adalah } \\
\text { Sri Kertanegara }\end{array}$ & $\begin{array}{l}\text { Bagaimana } \\
\text { hubungan Raden } \\
\text { Wijaya dengan Sri } \\
\text { Kertanegara? }\end{array}$ & $\begin{array}{l}\text { Hubungan antara Raden } \\
\text { Wijaya dan Sri } \\
\text { Kertanegara sangat baik, } \\
\text { karena Raden Wijaya } \\
\text { adalah menantunya. }\end{array}$ \\
\hline $\begin{array}{l}\text { Raja Gelang-Gelang } \\
\text { yang menyerang } \\
\text { Kertanegara } \\
\text { adalah } \\
\text { Jayakatwang yang } \\
\text { merupakan masih } \\
\text { keturunan dari } \\
\text { Raja Kertajaya } \\
\text { (Kadiri) yang } \\
\text { dikalahkan oleh } \\
\text { Ken Angrok } \\
\text { (Singhasari) pada } \\
\text { 1222 M. }\end{array}$ & $\begin{array}{l}\text { Bagaimana } \\
\text { hubungan } \\
\text { Jayakatwang dengan } \\
\text { Kertanegara? }\end{array}$ & $\begin{array}{l}\text { Hubungan antara } \\
\text { Jayakatwang dan } \\
\text { Kertanegara saling } \\
\text { bermusuhan, karena } \\
\text { Jayakatwang ingin } \\
\text { membalas dendam kakek } \\
\text { buyutnya yaitu Kertajaya } \\
\text { atas Ken Angrok yang } \\
\text { merupakan kakek buyut } \\
\text { dari Kertanegara. }\end{array}$ \\
\hline
\end{tabular}

1. Memberikan tugas membaca teks yang lain secara berkelompok maupun individu. Menulis apa yang telah mereka ketahui dari teks bacaan dan mempresentasikan dengan teman sekelasnya. 
2. Menutup kegiatan pembelajaran dengan merefleksikan dari kegiatan yang telah dilakukan selama proses pembelajaran.

\section{Meningkatkan Literasi Peserta Didik Dengan Metode K- W-L}

Literasi baca dan tulis merupakan pengetahuan dan kecakapan yang dimiliki oleh peserta didik untuk membaca, menulis, mencari, menelusuri, mengolah, dan memahami informasi untuk menganalisis, menanggapi, dan menggunakan teks tertulis untuk mencapai tujuan, mengembangkan pemahaman dan potensi, serta untuk berpartisipasi di lingkungan sosial (Atmazaki, 2017: 6). Metode K-W-L secara empiris dapat meningkatkan literasi membaca dan menulis peserta didik dalam proses pembelajaran.
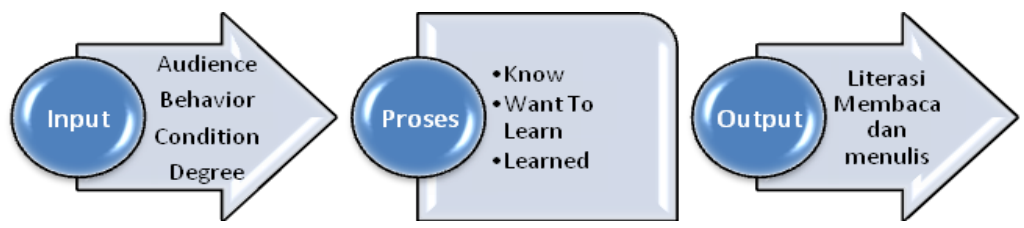

Gambar 1. Diagram Peningkatan Literasi dengan Sistem Pembelajaran dengan Metode $\mathrm{K}-\mathrm{W}$-L

Pada gambar diatas dapat dipahami bahwa peningkatan literasi membaca dan menulis dengan dengan metode $\mathrm{K}-\mathrm{W}-\mathrm{L}$ dapat dilakukan pertama kali yaitu melihat inputnya dengan melakukan analisis ABCD (Audience, Behavior, Condition, and Degree). Audience dalam artian guru melihat peserta didik sebagai subjek maupun objek dalam kegiatan pembelajaran. Dalam kegiatan ini guru dapat merumuskan tujuan pembelajaran sesuai dengan karakteristik peserta didiknya. Behavior yaitu tingkah laku yang diharapkan oleh peserta didik setelah mengikuti kegiatan pembelajaran dengan metode K-W-L. Dalam hal ini guru dapat merumuskan 
kegiatannya dengan menggunakan KKO (kata kerja operasional). Condition adalah keadaan peserta didik sebelum dan sesudah melakukan kegiatan pembelajaran. Dalam hal ini guru menyiapkan sumber informasi yang guna mendukung kegiatan K-W-L. Dengan adanya sumber informasi tersebut maka dirumuskanlah dengan menyertakan kata "diberikan", contoh yaitu diberikan artikel, peserta didik dapat menganalisis berdirinya kerajaan Singhasari. Kemudian degree dapat diartikan sebagai yang harus dicapai oleh peserta didik setelah melakukan K-W-L yang ditunjukan dalam hasil belajar. Tingkat degree bergantung pada kekuatan materi yang disajikan serta sejauh mana peserta didik dapat menguasai suatu informasi yang diberikan oleh guru.

Setelah melakukan analisis input dengan prinsip ABCD, maka melakukan kegiatan pembelajaran dengan K-W-L yaitu memberi bacaan, memberi petunjuk pengisian tabel $\mathrm{K}-\mathrm{W}-\mathrm{L}$, memberikan tugas dan mempresentasikan hasil yang didapatkannya, dan merefleksikan kegiatan pembelajaran. Setelah melakukan kegiatan pembelajaran, guru melakukan evaluasi pembelajaran dengan mengamati sejauh mana peserta didik dapat membaca, menulis, mencari, menelusuri, mengolah, dan memahami informasi untuk menganalisis, menanggapi, dan menggunakan teks tertulis untuk mencapai tujuan, mengembangkan pemahaman dan potensinya.

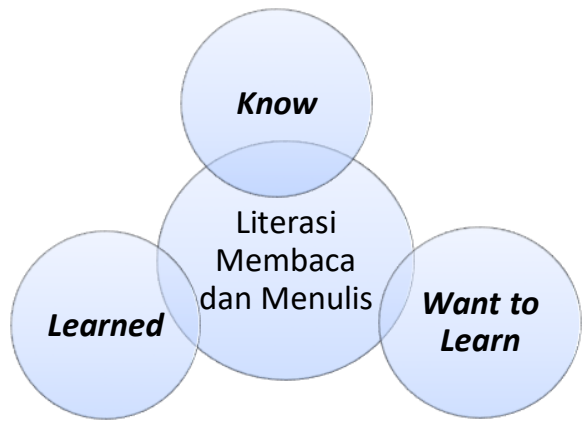

Gambar 2. Diagram Proses Pembelajaran Literasi Membaca dengan Metode $\mathrm{K}-\mathrm{W}$-L 


\section{Kesimpulan}

Metode pembelajaran K-W-L dapat dilakukan pertama kali yaitu dengan melakukan analisis input dengan prinsip ABCD. Kegiatan kedua (proses) yaitu melakukan kegiatan K-W-L dengan 3 tahapan yaitu (1) Know yaitu mengetahui apa yang dibaca oleh peserta didik, (2) Want to Learn, yaitu apa yang ingin diketahui oleh peserta didik setelah membaca dan (3) Learned, yaitu mempelajari apa yang ingin diketahui setelah membaca. Kegiatan ketiga (output) yaitu guru mengamati sejauh mana peserta didik dapat membaca, menulis, mencari, menelusuri, mengolah, dan memahami informasi untuk menganalisis, menanggapi, dan menggunakan teks tertulis untuk mencapai tujuan, mengembangkan pemahaman dan potensinya melalui evaluasi pembelajaran.

Metode pembelajaran K-W-L pada PTMT Pasca Pandemi Covid-19 dapat memberikan peningkatan dan pengaruh yang positif terhadap literasi membaca dan menulis apabila guru kreatif untuk mengembangkannya dengan mendayagunakan sumber informasi baik secara manual (koran, artikel, buku, dan jurnal) maupun digital seperti $e$ book dan e-journal, (2) peserta didik dapat diajak untuk samasama belajar memahami sebuah informasi dari sumber yang didapatkan, (3) guru dapat mengarahkan peserta didik agar mengonstruksi ide-idenya setelah membaca sebuah informasi, dan (4) mendayagunakan perpustakaan sebagai sarana literasi membaca agar peserta didik terbiasa dengan membaca buku.

\section{Daftar Pustaka}

Atmazaki, dkk. 2017. Panduan Gerakan Literasi Nasional. Jakarta: Kementerian Pendidikan dan Kebudayaan.

Budianti, Y \& Damayanti, N. 2017. Pengaruh Metode KWL (Know Want to Learn) terhadap Keterampilan dan Minat Membaca Peserta didik, Indonesian Journal of Primary Education. 1 (2): 13-18. 
Damayanti, A.R. 2015. Literasi dari Era ke Era, Sasindo: Jurnal Pendidikan Bahasa dan Sastra Indonesia. 3 (1): 1-10.

Hilmi, A., Asrori, I \& Ridwan, N.A. 2019. The Implementation of K-W-L (Know-Want To Know-Learned) Strategy to Improve Student's to Improve Student's Arabic Text Reading Ability of Grade XI of MA Bahrul Ulum, Alsinatuna: Journal of Arabic Linguistic and Education. 5 (1): 30-46.

Sani, R.A. 2014. Inovasi Pembelajaran. Jakarta: Bumi Aksara.

Satgas Covid-19. 2021. Peta Sebaran Covid-19, (Online), (https://covid19.go.id/peta-sebaran-covid19), diakses pada tanggal 13 November 2021.

Solihin, L., Utama, B., Pratiwi, I \& Novirina. 2019. Indeks Aktivitas Literasi Membaca 34 Provinsi. Jakarta: Pusat Penelitian Kebijakan Pendidikan dan Kebudayaan, Badan Penelitian dan Pengembangan, Kementerian Pendidikan dan Kebudayaan.

Subakti, H., Oktaviani, S \& Anggraini, K. 2021. Implementasi Gerakan Literasi Sekolah pada Masa Pandemi Covid-19 dalam Meningkatkan Minat Baca Peserta didik Sekolah Dasar, Jurnal BASICEDU. 5 (4): 2489-2495.

Sumarti, E., Jazeri, M., Manggiasih, N.P \& Mashitoh, D. 2020. Penanaman Dinamika Literasi Pada Era 4.0, Jurnal LITERASI. 4 (1): 58-66. 


\title{
OPTIMALISASI PEMBELAJARAN BAHASA INGGRIS PADA PERTEMUAN TATAP MUKA TERBATAS
}

\author{
Dewi Sartika, S.Pd., M.Pd. ${ }^{6}$ \\ (UNISKI Kayuagung)

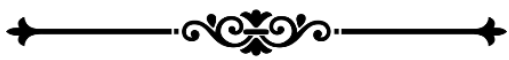

"Metode pembelajaran dan teknik pembelajaran aktif dapat digunakan oleh guru dan mengkombinasikannya sehingga pengajaran Bahasa Inggris pada saat PTM dapat dilakukan dengan optimal dan tujuan pembelajaran tercapai serta siswa memahaminya"

Sejak diberlakukannya aturan pertemuan tatap muka Sterbatas yang disingkat PTM, maka setiap sekolah melakukan upaya untuk mempersiapkan segala sarana dan prasana untuk menyelenggarakan pertemuan tata muka terbatas. Waktu yang diberikan saat tatap muka hanya terbatas dan mengajarkan siswa dengan jumlah terbatas. Dikarenakan terbatasanya waktu saat tatap muka di kelas, seringkali membuat pembelajaran bahasa Inggris menjadi kurang efektif. Mengingat kemampuan setiap anak di dalam kelas yang beragam dan waktu pembelajaran yang terbatas,

6 Penulis lahir di Palembang, 24 April 1982, penulis merupakan Dosen Universitas Islam Ogan Komering Ilir (UNISKI) Kayuagung dalam bidang Pendidikan Bahasa Inggris, penulis menyelesaikan gelar Sarjana Pendidikan Bahasa Inggris di Universitas Sriwijaya (2005), sedangkan gelar Magister Pendidikan diselesaikan di Universitas Sriwijaya Program Studi Pendidikan Bahasa (2010), dan sedang melanjutkan program Doktor Ilmu Pendidikan Bahasa (Pendidikan Bahasa Inggris) di Universitas Negeri Semarang (2021). 
maka guru di tuntut untuk membantu siswa agar menguasai kemampuan dalam Bahasa Inggris yang memadai. Oleh sebab itu, guru dapat menggunakan berbagai macam cara untuk mengoptimalkan waktunya dengan menggunakan berbagai macam teknik untuk meningkatkan kemampuan berbahasa Inggris siswa sesuai dengan kondisi siswa di kelas. Adapun variasi metode pembelajaran yang dapat dilakukan adalah sebagai berikut.

\section{Grammar Translation Method (GTM)}

Beberapa teknik dalam Grammar Translation Method yang dapat dilakukan adalah sebagai berikut.

a. translation of a literary passage; guru menyuruh siswa mengartikan bagian bacaan Bahasa Inggris ke Bahasa Indonesia. Bacaan tersebut dapat berupa cerita fiksi misalnya dogeng, cerita rakyat, legenda dan lain-lain yang menarik hati siswa.

b. reading comprehension questions; guru menyuruh siswa mengerjakan soal setelah mereka membaca teks.

c. antonyms/synonyms; guru menyuruh siswa untuk mencari persamaan dan lawan kata yang terdapat dalam teks bacaan.

d. fill in the blanks; guru menyuruh siswa melengkapi kata-kata yang hilang yang terdapat dalam teks.

e. deductive application of rule; siswa menggunakan beberapa contoh yang berbeda sesuai dengan aturan tata bahasa dan disajikan dengan contoh.

\section{Audio - Lingual Method}

Guru dapat menggunakan repetition drill dan substitution drill ketika mengajar Bahasa Inggris menggunakan AudioLingual Method. Kegiatan ini dianggap efektif bagi siswa pemula misalnya; dalam repetition drill; guru berkata I teach English every Wednesday, kemudian siswa meniru dengan mengucapkan I teach English every Wednesday. Sedangkan dalam substitution drill; guru berkata Syafira is prety. 
Kemudian guru berkata lagi smart. Kemudian siswa mengucapkan Syafira is smart mengikuti pola kalimat yang diucapkan guru pada kalimat pertama.

\section{Total Physical Response (TPR)}

Kegiatan TPR yang efektif dapat dilakukan siswa di tempat duduk mereka. Misalnya, setiap siswa memiliki kit seperti interior dapur. Kemudian, guru mengatakan dalam bahasa Inggris, "Put the man in front of the sink." Dengan papan permainan yang ditampilkan sehingga terlihat jelas oleh siswa, guru menempatkan pria di dapur kit guru dan siswa mengikuti dengan melakukan tindakan yang sama dalam kit mereka.

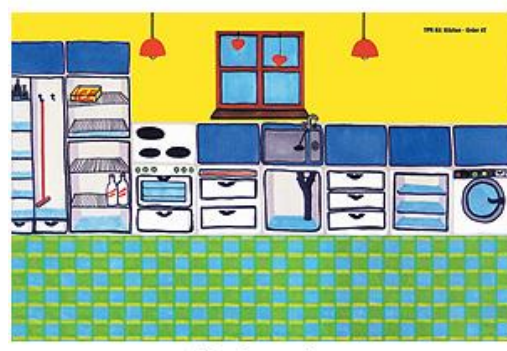

Playboard

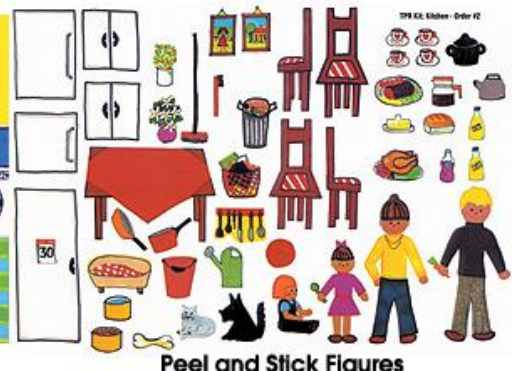

Peel and Stick Figures

Gambar 1. Interior Dapur

Selain itu, guru juga dapat melakukan imperative drill; guru memerintahkan siswa untuk melakukan sesuatu sehingga siswa bergerak untuk melakukan instruksi tersebut. Kemudian, guru juga dapat menyusun siswa melakukan conversational dialogue, role play, mempresentasikan sesuatu menggunakan OHP atau LCD serta menyusuh siswa untuk membaca dan menulis Bahasa Inggris agar menambah kosakatanya dan melatih menyusun kalimat sesuai dengan tenses. 


\section{Community Language Learning (CLL)}

Teknik-teknik CLL adalah tape-recording student conversation, reflective listening, transcription, human computer, reflection on experience, and small group tasks. Misalnya, guru menggunakan flashcards untuk level pemula yang memuat nama beserta identitas yang berbeda-beda. Guru memberi contoh sedikit percakapan dalam bahasa target, “Good morning. What's your name?" Kemudian, siswa menjawab, “My name’s Ratih." Dengan menggunakan bahasa asing dan gesture, guru memberi intruksi kepada siswa untuk memperkenalkan diri dan menanyakan informasi kepada teman sekelasnya dan mereka harus merespons pertanyaan dengan menggunakan bahasa Inggris. Mereka menjawab berdasarkan identitas baru mereka sesuai yang tertera di kartu sehingga terjadi pertukaran informasi secara autentik.

\section{Communicative Language Teaching (CLT)}

Richards (2006, p. 18) menyarankan beberapa kegiatan yang dapat diterapkan dalam ruang kelas CLT. Kegiatan tersebut antara lain sebagai berikut:

a. Information gap activities; siswa menggunakan, mencari atau menemukan kosakata, tata bahasa, dan/atau komunikasi yang hilang untuk menyelesaikan tugas.

b. Jigsaw activities; kelas dibagi menjadi beberapa kelompok dan setiap kelompok atau orang memiliki bagian dari informasi yang dibutuhkan untuk menyelesaikan suatu kegiatan. Ketika melakukannya, mereka harus menggunakan kata-kata mereka sendiri untuk berkomunikasi secara bermakna dan mengambil bagian dalam praktik komunikasi yang bermakna.

c. Picture series; seorang siswa atau sekelompok siswa menceritakan sebuah cerita berdasarkan serangkaian gambar berurutan; gambar mungkin perlu diurutkan terlebih dahulu. 
d. Story telling; siswa menceritakan kembali secara lisan tentang legenda, fabel, cerita rakyat atau dongeng, dan cerita asli di depan kelas.

e. Information-transfer activities; siswa dituntut untuk mengambil informasi yang disajikan dalam satu bentuk dan menyajikannya dalam bentuk yang berbeda.

f. Debates and group discussions; melibatkan derivasi informasi baru dari informasi yang diberikan melalui proses inferensi, penalaran praktis, dan lain-lain. Dalam kegiatan ini, siswa dapat memberikan pendapat mereka kepada orang lain dan membandingkan nilai, opini, atau keyakinan mereka atau orang lain.

g. Role plays or mini-dramas adalah kegiatan di mana siswa diberikan peran dan berimprovisai adegan berdasarkan informasi atau petunjuk yang diberikan.

Selain itu Yee (2017) juga menyebutkan beberapa Active Learning Techniques yang dapat diterapkan guru di kelas yaitu sebagai berikut.

a. Turn Taking Reading; guru membaca paragraf di layar (atau membiarkan siswa melakukannya), menginstruksikan mereka bahwa kita akan duduk diam sampai seseorang tergerak untuk membaca SATU kalimat, lalu orang lain siapapun akan memulai kalimat berikutnya.

b. Video Selfie; siswa diminta untuk membuat video tentang diri mereka sendiri melakukan pekerjaan rumah (atau lab) karena mereka akan menganggapnya lebih serius dan lebih baik untuk menghindari kesalahan.

c. Gallery Walk; siswa diberikan stiker titik berwarna kemudian siswa diminta untuk "memilih" pernyataan yang paling mereka setujui, dengan menggunakan persediaan titik terbatas pada topik yang telah ditulis 
sebelumnya yang dipajang di sekitar ruangan pada papan poster.

d. Circle the questions; buat selebaran yang berisi beberapa pertanyaan siswa tentang topik atau yang spesifik. Kemudian, instruksikan siswa untuk melingkari pertanyaan yang mereka tidak tahu jawabannya, lalu balikkan kertasnya.

e. Writing Fable; siswa menulis fabel hewan (atau garis besar ceritanya) yang mengarah pada nilai moral yang dibahas di kelas.

f. Board of Artwork; siswa mempublikasikan gambar/konsep abstrak yang dikumpulkan dan diserahkan untuk kegiatan sebelumnya serta menciptakan kesempatan untuk diskusi dan tanya jawab

Beberapa metode pembelajaran dan teknik pembelajaran aktif tersebut diatas dapat digunakan oleh guru. Guru dapat mengkombinasikannya sehingga pengajaran Bahasa Inggris pada saat PTM dapat dilakukan dengan optimal dan tujuan pembelajaran tercapai serta siswa memahaminya.

\section{Daftar Pustaka}

Direktorat Sekolah Menengah Atas. 2021. Pembelajaran Tatap Muka (PTM) pada Masa Pandemi Covid-19 di SMA. Jakarta Selatan: Kemenristek

Richards, J. C. 2006. Communicative Language Teaching Today. New York: Cambridge University Press

Yee, Kevin. 2017. 226 Active Learning Techniques. Iowa State University Center for Excellence in Learning and Teaching diakses dari https://www.celt.iastate.edu/wpcontent/uploads/2017/03/CELT226activelearningtech niques.pdf 


\section{PENTINGNYA SEBUAH INOVASI DALAM PERKEMBANGAN MODEL PEMBELAJARAN PASCA PANDEMI}

Ani Kurniawati, M.Pd. ${ }^{7}$

(Universitas Garut)

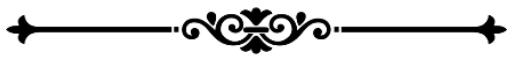

"Inovasi dalam pendidikan pasti tercapai tujuannya bilamana dalam menerapkan sebuah model pembelajaran yang ingin dikembangkan harus memakai strategi pembelajaran dan juga media pembelajaran yang tepat untuk diterapkan"

Dentingnya sebuah pengembangan suatu model
pembelajaran merupakan salah satu cara atau metode yang bisa digunakan oleh seorang pendidik dalam proses pembelajaran dengan tujuan ingin bisa mengembangkan suatu pendekatan yang lebih efektif dan efisien dalam mencapai tujuan pendidikan yang diinginkan. Dalam hal ini Suherman (2009, hal. 1) menjelaskan bahwa: "Model pembelajaran adalah belajar sebagai pengorganisasian lingkungan yang dapat menggiring siswa berinteraksi dan mempelajari bagaimana belajar". Sedangkan menurut

7 Penulis lahir di Tasikmalaya, 16 Juni 1988, penulis merupakan Dosen Pendidikan Jasmani Universitas Garut dalam bidang Sosiologi Olahraga dan Pendidikan Jasmani Adaptif, penulis menyelesaikan gelar Sarjana Pendidikan Kepelatihan Olahraga di Universitas Pendidikan Indonesia (2011), sedangkan gelar Magister Pendidikan Olahraga diselesaikan di Universitas Pendidikan Indonesia (2015). Penulis aktif dalam organisasi keolahragaan sebagai pelatih Cabang Olahraga Bowling di SOIna Kota Bandung dan juga Rugby Kabupaten Garut. 
Juliantine (2013, hal. 5) menjelaskan bahwa: "Dalam konteks pembelajaran, model adalah suatu penyajian fisik atau konseptual dari sistem pembelajaran, serta berupaya menjelaskan keterkaitan berbagai komponen sistem pembelajaran ke dalam pola/kerangka pemikiran yang disajikan secara utuh". Dari uraian teori diatas jika kita simpulkan adalah seorang pendidik itu perlu mamahami kondisi lingkungan dan juga harus bisa memikirkan pendekatan atau model pembelajaran apa yang bisa tepat untuk digunakan atau diberikan agar tujuan pendidikan itu bisa tercapai dengan efektif dan efisien sehingga sesuai dengan harapan.

Kita bisa tau bahwa model pembelajaran itu meliputi keseluruhan dari sistem pembelajaran yang mencakup komponen tujuan, kondisi pembelajaran, proses belajar mengajar, dan juga suatu evaluasi dari hasil pembelajaran itu sendiri. Bruce Joyce dan Marsha Weil (1996, hal. 42) menjelaskan bahwa: "Scientific method can be taught and has positive effects on the acquisition of information, concepts, and attitude". Jika seorang pendidik tidak melakukan sebuah inovasi dalam pengajaran maka pembelajarannya akan terasa tidak berarti dan juga tidak mampu untuk mengembangkan domain pembelajaran lain dan bisa dipastikan hal ini akan menyebabkan hasil belajar juga tidak dapat diraih dengan optimal. Oleh sebab itu penggunaan model pembelajaran yang bersifat scientific bisa mempengaruhi minat dan motivasi dalam hasil belajar itu sendiri.

Pada saat ini kita sudah bisa melewati situasi pembelajaran yang diterapkan yaitu pembelajaran daring, dimana pada saat itu kita sebagai seorang pendidik harus bisa membuat suatu inovasi penerapan model pembelajaran yang efektif yang bisa diterapkan dan itu bagi saya bukan hal yang mudah, dimana di tempat saya mengajar SDM yang saat itu ada sangatlah terbatas. Contohnya adalah tidak semua mahasiswa saya memiliki laptop atau smartphone yang memadai atau bahkan jika memiliki pun terkendala dengan 
jaringan dan sistem yang membuat mereka harus bisa beradaptasi dalam pelaksanaan pembelajaran secara daring. Akan tetapi dari itu semua saya belajar banyak hal, selain kesiapan yang dimiliki, ada hal yang mungkin harus bisa kita jadikan patokan bagaimana cara kita memberikan model pembelajaran yang sangat tepat untuk diberikan, karena bisa kita sama - sama ketahui bahwa dengan pembelajaran daring ini justru secara tidak langsung membuat minat dan juga motivasi untuk belajar menjadi sangat menurun. Sehingga dari pengalaman itu, saat ini kita sebagai seorang pendidik secara tidak langsung dituntut untuk mengahadapi sekaligus mempersiapkan model pembelajaran seperti apa yang akan diberikan pasca pandemi ini agar minat dan motivasi dalam belajar bisa kembali sebelum adanya pandemi.

Sebuah penerapan inovasi lebih ditujukan untuk sebuah perubahan, salah satunya adalah adanya peningkatan ke arah yang lebih baik. Sebuah inovasi implementasinya bukan hanya sebuah ide - ide dan pengetahuan saja. Akan tetapi harus kearah bagaimana cara untuk bisa meningkatkan ide ide serta pengetahuan itu menjadi meningkat dan bisa dijadikan suatu gambaran dari tercapainya sebuah inovasi itu sendiri. Dalam hal ini Sujana (2020, hal. 11) menjelaskan bahwa: "Inovasi dalam pendidikan bertujuan untuk meningkatkan mutu dari pendidikan tersebut". Sehingga bisa disimpulkan bahwa inovasi dalam pembelajaran itu merupakan salah satu hal yang harus mendapatkan perhatian khusus, adapun yang menjadi aspek inovasi itu sendiri adalah seperti keuangan, sarana prasarana, sumber daya, proses pembelajaran. Agar tujuan dari inovasi itu bisa tercapai peranan kita sebagai seorang pendidik dalam pembelajaran itu sangatlah penting, karena seorang pendidik merupakan salah satu faktor terpenting dalam keberhasilan pembelajaran, dimana pendidik itu adalah sebagai perencana, pelaksana dan sekaligus menjadi evaluator dalam keberhasilan pembelajaran itu sendiri. 
Dalam hal ini pentingnya sebuah inovasi untuk pendidikan salah satunya adalah untuk meningkatkan nilai, efisiensi proses dalam meningkatkan mutu pendidikan itu sendiri. Menurut OECD (dalam Sujana, 2020, hal. 18) menjelaskan bahwa inovasi dapat menambah nilai dalam pendidikan dengan alasan sebagai berikut:

1. Inovasi pendidikan dapat meningkatkan hasil pembelajaran dan kualitas penyediaan pendidikan.

2. Pendidikan dirasakan di sebagian besar negara sebagai sarana untuk meningkatkan kesetaraan kesejahteraan.

3. Organisasi publik termasuk pendidikan sering berada di bawah tekanan yang sama banyaknya dengan bisnis untuk meningkatkan efisiensi, meminimalkan biaya, dan memaksimalkan hasil.

4. Pendidikan harus tetap relevan dalam mengahadapi perubahan yang cepat terhadap masyarakat dan ekonomi nasional.

Kita sebagai seorang pendidik harus memiliki sebuah inovasi dalam pembelajaran yang bertujuan untuk meningkatkan mutu pendidikan, salah satunya adalah melalui model pembelajaran apa yang akan kita terapkan. Dalam hal ini suatu model pembelajaran itu meliputi keseluruhan sistem pembelajaran yang juga mencakup komponen tujuan, kondisi pembelajaran, proses belajar mengajar, dan juga evaluasi dari hasil pembelajaran itu sendiri. Berikut adalah dasar - dasar dalam pertimbangan pemilihan model pembelajaran (Juliantine, 2013, hal. 6) diantaranya adalah sebagai berikut:

1. Pertimbangan terhadap tujuan yang akan dicapai.

2. Pertimbangan terhadap bahan atau materi pembelajaran.

3. Pertimbangan terhadap peserta didik atau siswa.

4. Pertimbangan yang bersifat non teknis (apakah model yang akan digunakan memiliki nilai efektif dan efisien). 
Selain itu menurut Kardi dan Nur (dalam Majid, 2017, hal 14) model pembelajaran juga mempunyai empat ciri khusus yang membedakan dengan strategi, metode, atau prosedur diantaranya adalah sebagai berikut:

1. Rasional teoretis logis yang disusun oleh para pencipta atau pengembangnya.

2. Landasan pemikiran tentang apa dan bagaimana peserta didik belajar (tujuan pembelajaran yang akan dicapai).

3. Tingkah laku pembelajaran yang diperlukan agar model tersebut dapat dilaksanakan dengan berhasil.

4. Lingkungan belajar yang diperlukan agar tujuan pembelajaran itu dapat tercapai.

Setelah kita bisa memahami apa itu inovasi dan juga model pembelajaran ada hal penting yang harus seorang pendidik bisa dikembangkan, yaitu strategi pembelajaran dan juga media pembelajaran. Kenapa itu dikatakan penting, alasannya adalah karena sebuah inovasi dan model pembelajaran yang akan diterapkan kuranglah sempurna jika tidak dibarengi dengan adanya sebuah strategi pembelajaran dan juga sebuah media pembelajaran apa yang akan digunakan. Menurut Majid (2017, hal. 7) menjelaskan bahwa: "Strategi pembelajaran merupakan rencana tindakan (rangkaian kegiatan) termasuk penggunaan metode dan pemanfaatan berbagai sumber daya atau kekuatan dalam pembelajaran yang disusun untuk mencapai tujuan tertentu, yakni tujuan pembelajaran". Sedangkan menurut Karsidi (2018, hal. 4) menjelaskan bahwa: "Media pembelajaran adalah segala sesuatu yang digunakan untuk menyalurkan pesan serta dapat merangsang pikiran, perasaan, perhatian, dan kemauan siswa sehingga dapat mendorong terjadinya proses belajar yang disengaja, bertujuan dan terkendali". Dapat disimpulkan bahwa sebuah inovasi dalam pendidikan pastilah akan bisa tercapai tujuannya bilamana dalam menerapkan sebuah model pembelajaran jika ingin bisa dikembangkan haruslah juga memakai strategi pembelajaran dan juga media pembelajaran 
yang juga tepat untuk bisa diterapkan. Oleh karena itu jadilah seorang pendidik yang selalu melakukan sebuah inovasi melalui kreativitasnya untuk bisa mengembangkan apa yang harus dikembangkan dalam dunia pendidikan saat ini, salah satunya adalah dalam menerapkan model pembelajaran apa yang dirasa tepat oleh kita sebagai pendidik untuk diberikan pasca pandemi ini.

\section{Daftar Pustaka}

Joyce, B and Weil, M. (1996). Model of Teaching, Fifth Edition. Boston: Allyn and Bacon.

Juliantine, dkk. (2013). Model - Model Pembelajaran Pendidikan Jasmani. FPOK UPI Bandung.

Majid, Abdul. (2017). Strategi Pembelajaran. Bandung: Bandung: PT. Remaja Rosdakarya.

Suherman, Adang. (2009). Revitalisasi Pengajaran Dalam Pendidikan Jasmani. Bandung: CV. Bintang Warliartika.

Sujana, Atep. (2020). Model - Model Pembelajaran Inovatif Teori dan Implementasi. Depok: PT. Rajagafindo Persada.

Suryani, dkk. (2018). Media Pembelajaran Inovatif dan Pengembangannya. Bandung: Bandung: PT. Remaja Rosdakarya. 


\title{
RETURN SPIRIT BELAJAR MAHASISWA PASCA PANDEMIK
}

\author{
Dr. Yayat Suharyat ${ }^{8}$ \\ (Universitas Islam “45” Bekasi)

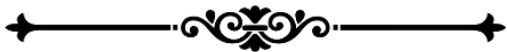

"Mengembalikan semangat belajar mahasiswa dengan menanamkan karakter cerdik cendikia, siap selalu menerima perubahan dan perkembangan teknologi, dan menguasai kecakapan kompetensi yang dibutuhkan untuk bekerja dan mengembangkan jiwa kewirausahaan pada masa kini dan masa yang akan datang"

\section{A. Pendahuluan}

Kegiatan pembelajaran adalah hak setiap manusia, oleh Mkarena itu sesulit apapun kondisinya maka aktivitas ini harus tetap berlangsung. Terlebih lagi di dalam ajaran Islam, menuntut ilmu berhukum wajib (Tholabul ilmu fariidhotun 'ala kulli muslimin wamuslimatin). Pada masa pandemik belajar mengajar tetap berlangsung dengan metode online, kurang lebih selama dua tahun kegiatan ini harus dilakukan untuk membatasi pergerakan dan kerumuman manusia dalam segala aktivistasnya. Organisasi kesehatan dunia (WHO) telah memberikan petunjuknya tentang hal ini agar

\footnotetext{
${ }^{8}$ Penulis lahir di Bekasi pada tanggal 12 Desember. Penulis merupakan Dosen di Jurusan Pendidikan Agama Islam UNISMA Bekasi bidang kajian Metodologi Penelitian, Teknik Analisis Data dan Bidang Kajian PendidIkan Islam. Penulis menyelesaikan gelar Sarjana Pendidikan Agama Islam di Fakultas Tarbiyah, Jurusan, Universitas Islam "45" (UNISMA) Bekasi (1993).
} 
manusia dapat menjaga kesehatannya, tidak menularkan dengan selalu menjaga jarak (social distancing). Belajar merupakan kebutuhan dasar manusia agar dapat memenuhi hajatnya sebagai khalifatullah, maka dari itu hakikatnya kegiatan belajar akan dilindungi Allah SWT. Allah akan menjaga orang yang menuntut ilmu dengan rahmat dan karunia-Nya. Orang yang sedang aktif belajar akan dinaungi dari kesulitan, baik kesulitan fisik maupun kesulitan bathin. Artinya bahwa perlindungan Allah sangat paripurna untuk orang yang sedang menuntut ilmu, karena dari dirinyalah Allah SWT akan menitipkan alam semesta kepadanya. Dalam Kitab Minhajul Qaashidin dengan mengutip HR Thirmidzi, Ahmad, Ibnu Hibban disebutkan kemulyaan para penuntut ilmu melalui hadis yang shahih, Rasulullah SAW bersabda: Inna malaaikati latadhou' ajnihataha litholibil ilmi ridho bima yathlub (Sesungguhnya malaikat benar-benar meletakkan sayap-sayapnya bagi pencari ilmu karena ridho terhadap apa yang ia cari). (Abu Qudamah Al Maqdisi: 5)

Fungsi belajar bagi manusia adalah mengaktualisasi daya menjadi energi, karena setiap jiwa memiliki kekuatan (daya) untuk menjadikan seseorang dapat berperan dalam kehidupan individual dan sosial. Setiap jiwa memiliki ketersediaan daya untuk dapat dimanfaatkan sebagai kegiatan belajar dalam melatih kecakapan dan ketajaman cipta, rasa dan karsa sehingga daya yang berupa daya mengenal, daya mengingat, daya berpikir, daya fantasi dan sebagainya dapat berfungsi secara baik untuk membuat pertimbangan dalam kehidupan.

Belajar yang paling mudah adalah belajar tentang lingkungan, malah belajar yang paling sulit adalah tentang diri sendiri. Jadi, membuat diri kita cerdas dan berpengetahuan sangat dibutuhkan peran lingkungan. Orang lain berperan dalam mempengaruhi kita, maka dari itu belajar secara konvensional membutuhkan tempat, media, sumber dan aktor pengajarnya. Guru dan dosen 
(ustadz/ustadzah) menjadi aktor penting dalam belajar. Bagi seorang pembelajar, belajar bisa dilakukan dimana saja, dengan siapa saja, bahkan terkadang belajar dengan secara mandiripun mereka bisa melakukan, namun jumlah pembelajar swakarsa ini hanya sedikit sekali, karena sebagian besar orang perlu intervensi lingkungan untuk belajar.

\section{B. Pembahasan Kajian}

1. Dimensi Pembelajaran Tatap Muka Terbatas (PTMT) sebagai Kebutuhan.

Mahasiswa adalah pembelajar yang mendapat perhatian penting dalam kegiatan pembelajaran di universitas (perguruan tinggi). Jumlah mahasiswa di Indonesia sejajar dengan jumlah usia belajar pasca sekolah menengah, seandainyapun ada yang tidak melanjutkan jumlahnya sangat kecil. Mahasiswa merupakan usia potensial untuk berkembang dan tumbuh, hal ini terkait dengan masa depan bangsa. Jangan sampai terjadi loss generation karena kondisi pandemik menjadikan mahasiswa tidak secara penuh mendapatkan layanan belajar dan pendidikan yang memadai, maka program Pembelajaran Tatap Muka Terbatas (PTMT) adalah strategi yang harus dicermati agar efektif dan efisien. Efektif artinya pembelajaran benar-benar dapat menggugah spirit mahasiswa dan dapat menariknya kembali untuk mencintai kegiatan belajar mereka setelah sekian lama (hampir 2 tahun) berada di rumah dengan lingkungan yang bebas terbuka dalam arti bukan lingkungan kampus sebagai lingkungan belajar mereka. Efisien maksudnya adalah masih berada dalam suasana pandemik, maka setiap proses pembelajaran harus mampu mengangkat materi bahan ajar sebagai kebutuhan mahasiswa yang betul-betul menunggu pola belajar tatap muka yang ditunggu-tunggu mereka. Setiap kegiatan belajar adalah mengisi wilayah kognitif, namun juga tidak boleh lupa untuk mempertimbangkan domain penting 
lainnya yaitu afektif dan psikomotorik. Dalam kondisi pandemik seorang dosen selama dua tahun hanya berkutat pada domain kognitif secara menyeluruh karena pembelajaran daring memiliki keterbatasan dimensi transmisi. Dosen tidak mampu secara maksimal menunjukkan performansi afeksi dan psikomotorik secara lebih teruji dan pada pendidikan vokasi ini justru menjadi kekhawatiran karena keterampilan teknis jangan sampai gagal transfer, jika tidak berhasil dalam transfer ketrampilan maka sekolah vokasi bisa berubah menjadi "sastra".

\section{Problema Psikis Dosen dan Mahasiswa}

Pembelajaran daring telah mengubah tampilan psikis dosen dan mahasiswa dalam interaksi akademik. Dosen secara kasat mata dapat menjadi "monster" bagi mahasiswa disebabkan oleh tertutupnya pintu jiwa dalam tatap muka secara langsung. Dosen menjadi lebih banyak memberikan materi di samping juga penugasan, materi yang disampaikan dosen belum tentu juga terukur penerimaannya secara utuh oleh mahasiswa. Di sisi lain dosen sudah merasa yakin untuk memberikan tugas kepada mahasiswa untuk menjawab soal dan kuis yang diajukan. Ini problema umum yang dihadapi dosen ketika mengajar via daring. Kondisi ini bukan karena persoalan kebiasaan dosen tetapi lebih kepada ungkapan rasa ketika mengajar daring tidak setepat ketika pembelajaran dengan tatap muka, inilah dimensi pendidikan yang sesungguhnya. Pendidikan adalah menimbang nilai dengan penanaman melalui rasa emosional. Dalam pembelajaran ada empati, toleransi, kesepakatan bersama, motivasi, pembimbingan, pengarahan dan uswatun hasanah (contoh teladan). Pembelajaran daring dapat mengajukan proporsi tentang pembimbingan dan pengarahan secara utuh, namun sedikit sekali menyajikan nilai tentang empati, toleransi dan kesepakatan bersama. Hampir pasti melalui pembelajaran daring mahasiswa kesulitan mendapat 
motivasi dari dosen, juga tentang contoh suri teladan (uswatun hasanah). Dosen adalah mesin kehidupan dan contoh hidup yang nyata bagi mahasiswa, di dalam diri dosen ada interaksi spirit, nilai kejuangan dan perjuangan dosen yang dapat dicontoh secara langsung dan tidak langsung oleh mahasiswa yang dibimbingnya. Terkadang dengan memandang wajah dosen saja seorang mahasiswa sudah terinspirasi dalam perjuangan akademik dan perjuangan hidup yang dapat mendorong setiap mahasiswa bergerak positif membangun dirinya.

Mengenai hal ini artikel yang ditulis Markus Masan Bali (2013:2) menyatakan bahwa setiap dosen secara otomatis akan menjadi petugas dalam internalisasi nilai-nilai atau karakter kepada para mahasiswanya yang membutuhkan pemahaman, keterampilan, dan kompetensi mengenai nilai-nilai karakter. Dosen akan mampu memancarkan dari dalam dirinya karakter-karakter mulia yang dapat diteladani oleh para mahasiswa. Keteladanan memiliki bahasa atau pesan tersendiri yang sangat menguat dalam diri mahasiswa. Keteladanan tidak banyak berbicara atau memberi penjelasan tentang tip atau pengetahuan menjadi baik dan benar. Akan tetapi, para mahasiswa dapat melihat dan menyaksikan sendiri seorang dosen dalam berbicara, bertindak, dan bahkan mindset dari dosen sendiri yang terpancar lewat cara mengajarnya. Singkatnya, untuk internalisasi nilai-nilai atau karakter kepada para mahasiswa, seorang dosen memiliki karakter yang kuat sehingga ketika mengajar di kelas memiliki daya atau "ruh" menggerakkan mahasiswa untuk meniru dan mengikuti yang disampaikan.

Dari uraian dan dari artikel di atas membuktikan kondisi psikis dosen dan mahasiswa menyesuaikan secara ekstrim terhadap gaya mengajar apapun yang diterapkan dalam pembelajaran selama pandemik, dan secara umum diketahui banyak nilai-nilai yang hilang yang tidak tersampaikan dalam proses pembelajaran secara daring. 
Inilah yang perlu dipersiapkan kembali oleh setiap kampus agar mahasiswa dan dosen dapat segera masuk dalam kondisi normal yaitu belajar mengajar dengan segala kemampuan dan kompetensinya sebagai penyampai ilmu, sebagai motivator bagi mahasiswa, sebagai inspirator dan inisiator interaksi pembelajaran yang membuat mahasiswa bukan hanya cerdas, tetapi juga trampil dan cerdik dalam mensiasati samudera kehidupan yang terbentang luas di depannya.

\section{Pendidikan Sesungguhya di Perguruan Tinggi}

Serentetan kebijakan pendidikan di perguruan tinggi ditujukan hanya dengan satu tujuan yaitu mempersiapkan generasi Indonesia agar mampu bersaing dan berkompetisi dalam kancah internasional, meningkatkan harkat dan martabat bangsa dengan kemajuan dan peradaban di masa depan. Pandemik memang melanda seluruh belahan bumi di dunia ini, peran seluruh komponen bangsa untuk membuat pandemik cepat berakhir dan kembali hidup normal dengan adaptasi kebiasaan baru pasca pandemik. Persiapan yang sangat perlu dan penting untuk ini adalah sikap negara, dan rakyat Indonesia untuk berhadapan dengan kondisi pandemik ini. Singapura misalnya telah menyatakan Corona Virus sebagai gejala flu biasa. Memang seolah-olah ini sepertinya sangat berani, tetapi langkah ini ditempuh tentu dengan pertimbangan matang, persiapan dan sosialisasi kelaziman dan kebiasaan rakyatnya walaupun hidup dalam "ancaman" tetapi tetap menjadi kewajiban pemerintah untuk memberikan ketenangan dan perlindungan bagi rakyatnya. Tindakan preventif dipadukan dengan kesiapan kuratif secara masif tentu merupakan penjaminan bagi kehidupan rakyat di negerinya.

Normalisasi perasaan secara lahir dan bathin menjadi perlu dan penting agar mobilitas warga terlindungi dalam kondisi sesulit apapun. Peran negara tentu sangat dominan 
bagi siapapun yang hidup di dalamnya. Pendidikan tinggi adalah gerbang kemajuan bangsa yang sangat mudah dibuatkan indeks keberhasilannya dan peringkatnya dalam tatakelola internasional. Maka tidak ada jalan lain kecuali secepatnya menormalisasikan seluruh dimensi kehidupan khususya pendidikan, termasuk di dalamnya adalah pendidikan tinggi.

Metode yang paling mungkin adalah mendukung sepenuhnya program pencegahan virus ini agar tidak menulari dan berkembang melalui gaya hidup yang seluruhnya direvisi agar diperoleh perubahan dan pencegahan melalui pendidikan dan penyampaian yang paling mudah adalah pada warga lembaga pendidikan. Jadi kebijakan pembelajaran online harus segera ditinjau ulang secara serius disebabkan banyak terkendala terhadap pencapaian komunikasi psikis dan rasa sehingga perkembangan psikis, sosial, dan spiritual mahasiswa sebagai peserta didik (subyek didik) dimungkinkan terkendala secara krusial. Modul belajar, sistem penilaian pembelajaran harus juga disiapkan revisinya agar mahasiswa tidak pada posisi dirugikan. Alih-alih memudahkan dan mentoleransikan "nilai manis" (A-B) sebagai nilai akhir ujian karena kondisi darurat namun tidak memberikan pertolongan kompetensi untuk masa depan lulusan, akan membuat jurang menganga di hadapan kita semua. Maka sebaiknya orientasi penilaian diubah sedemikian rupa agar sejalan dan linier dengan perubahan modul dan pencapaian materi ajar yang jelas, konstruktif dan mengajarkan materi yang benar-benar atas kebutuhan mahasiwa untuk kehidupan masa kini dan masa yang akan datang sebagai generasi milenial. Pendidikan di perguruan tinggi bukan hanya sekedar mengetahui dan memahami ilmu pengetahuan yang dimiliki mahasiswa dan lulusan perguruan tinggi tersebut, tetapi lebih penting dan mendesak adalah menanamkan karakter cerdik cendikia, siap selalu menerima perubahan 
dan perkembangan teknologi, di samping tentunya adalah menguasai kecakapan dan kompetensi yang dibutuhkan untuk bekerja dan mengembangkan jiwa kewirausahaan pada masa kini dan masa yang akan datang.

\section{Daftar Pustaka}

Masan Bali, Markus. Peran Dosen Dalam Mengembangkan Karakter Mahasiswa. Humaniora Vol.4 No.2 Oktober 2013: 800-810. https://media.neliti.com/media/publications/166927ID-peran-dosen-dalam-mengembangkan-karakter.pdf

Qudamah Al Maqdisi, Abu. Mukhtasasar Minhajul Qashidin.

Darus Sunnah Press, Cipinang Muara Jatinegara 2014 


\title{
OPTIMALISASI PEMBELAJARAN TATAP MUKA TERBATAS DENGAN PENERAPAN MODEL PEMBELAJARAN FLIPPED CLASSROOM
}

\author{
Diki Septiawan, S.Pd. ${ }^{9}$ \\ (SMA Negeri 1 Subang Kab. Kuningan)

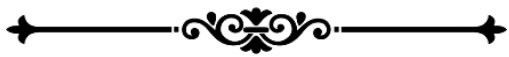

"Strategi flipped classroom memberikan keleluasaan siswa untuk belajar mandiri di rumah dan dapat mengulang-ngulang materi yang dipelajari sehingga siswa lebih matang dan siap saat pembelajaran tatap muka terbatas"

Tahun 2020 adalah tahun yang sangat berat bagi 1 masyarakat Indonesia dengan adanya kejadian penyebaran virus Covid 19, sebuah wabah virus yang bermula menyebar di kota wuhan negara china, meluas sehingga menjadi sebuah pandemic di seluruh dunia tidak terkecuali negara kita tercinta Negara Kesatuan Republik Indonesia. Pandemi ini tidak hanya menciptakan krisis kesehatan, namun juga mengganggu aktivitas lain seperti pendidikan, bahkan kasus Covid-19 di Indonesia menjadi salah satu kasus penyebaran terbesar di dunia, sehingga penyebaran virus ini masih menjadi fokus utama pemberlakuan kebijakan Indonesia.

\footnotetext{
${ }^{9}$ Penulis lahir di Kuningan, 11 September 1988. Penulis merupakan guru di SMA Negeri 1 Subang Kab.Kunigan. penulis menyelesaikan gelar Sarjana Pendidikan Matematika di Universitas Siliwangi.
} 
Dunia pendidikan menjadi salah satu bagian yang mendapatkan imbas sangat besar di masa pendemi ini,, Pandemi covid 19 yang terjadi di Indonesia mengakibatkan pemerintah melalui Kementerian Pendidikan, Kebudayaan, Riset, dan Teknologi (Kemendikbudristek) harus mengeluarkan kebijakan kegiatan proses belajar mengajar melalui kegiatan tatap muka di sekolah dihentikan, berganti dengan pembelajaran jarak jauh, semua peserta didik melaksanakan kegiatan belajar di rumah ( BDR ), hampir semua tingkatan pendidikan terdampak kebijakan ini tak terlepas jenjang pendidikan di tingkat menengah atas, kebijakan ini mempunyai pengaruh sangat besar terutama bagi sekolah sekolah yang secara tidak langsung merubah pola pendidikan di Indonesia yang selama ini berlangsung, kegiatan yang selama ini terasa nyaman dilaksanakan di dalam kelas, "dipaksa" berubah mengikutui keadaan bertransformasi disesuaikan dengan kebutuhan kondisi yang terjadi, setelah hampir 2 tahun pandemi ini berlangsung dengan bebrapa kebijakan ketat akhirnya pemerintah berhasil melandaikan penyebaran kasus covid 19, hal ini bak sebuah angin segar bagi dunia pendidikan dan pada akhirnya pada awal tahun ajaran 2021-2022, pemerintah melalui Kementerian Pendidikan, Kebudayaan, Riset, dan Teknologi (Kemendikbudristek) mengeluarkan kebijakan baru berdasarkan dengan keputusan bersama 4 menteri yaitu memperbolehkan kegiatan tatap muka berlangsung kembali meskipun masih dalam pemberlakuan secara terbatas serta dengan protocol keehatan yang sangat ketat, adapun teknis kebijakan pelaksanaan diserahkan kepada satuan pendidikan masing masing asalkan disesuaikan dengan standar yang telah ditetapkan pemerintah, hal inipun segera ditindaklanjutioleh setiap pengeleloladi lemnbaga pendidikan untuk menurunkan aturan dari kebijakan tersebut, namun kebijakan ini bukan berarti menyelesaikan permasalahan secara utuh, kebuijakan ini pun dalam hal ini menjadikan tantangan baru yang harus dihadapi dalam pendidikan di masa pandemi ini, antara lain Peran Guru. 
Guru dituntut untuk berfikir kreatif dan inovatif dalam memberikan pembelajaran secara daring berkombinasi luring atau terkenal dengan istilah Hybrid Learning yaitu adalah suatu sistem pembelajaran yang menggabungkan berbagai pendekatan dalam pembelajaran yaitu pembelajaran secar tatap muka, pembelajaran berbasis komputer, dan pembelajaran berbasis dengan media internet, sehingga anak anak tidak jenuh dalam menerima pembelajaran tersebut, bagaimana tingkat pemahaman anak atas materi materi yang telah diberikan secara daring, melalui dialog interaktif antara guru dan anak, menimbulkan tingkat pemahanan anak atas materi yang baik.

Salah satu tantangan lain bagi guru menghadapi kegiatan tatap muka terbatas ini adalah pembagian shift pembelajaran dimana peserta didik terbagi dalam dua bagian dalam pembagian jadwal tatap muka sehingga sebagian melaksanakan pembelajaran di rumah dengan menggunakan mode daring sebagian lagi melaksanakan pembalajaran di sekolah secara tatap muka langsung, kegiatan tersebut perlu disikapi oleh guru untuk bisa berperan secara utuh sehingga baik itu peserta didik yang di rumah baik di sekolah mendapatkan perlakuan yang sama sehingga memiliki tingkat pemahaman yang utuh mengenai materi yang disampaikan oleh guru, sehingga diperlakuan sebuah mode pembelajaran bebrbasis Interactive Learning yaitu Pembelajaran yang melibatkan interaksi antar berbagai komponen sebagai elemen substansial dari suatu aktivitas pembelajaran meliputi pendidik, peserta didik, bahan pembelajaran serta lingkungan belajar sebagai optimalisasi pembelajaran tatap muka terbatas.

Salah satu mode pembelajaran yang mungkin dilaksanakan guna menunjang peran guru untuk melaksanakan optimalisasi pembelajaran tatap muka terbatas tersebut diantaranya adalah dengan menggunakan model pembelajaran flipped classroom. Mode pembelajaran flipped classroom ini adalah Flipped classroom adalah salah satu 
model atau metode belajar yang meminimalkan pengajaran langsung dari guru, dimana dalam proses belajarnya pesrta didik mempelajari materi pelajaran terlebih dahulu di rumah, sedangkan kegiatan belajar mengajar di kelas hanya berupa pengerjaan tugas, berdiskusi tentang materi atau masalah yang belum dipahami saat belajar di rumah. Mode pembelajaran ini dapat menjadi solusi efektif ketika kebijakan pertemuan tatap muka terbatas ini dilaksanakan dengan tujuan untuk tidak mengurangi kesempatan belajar bagi peserta didik baik itu yang melaksankan pembelajaran di rumah ataupun pembelajaran secara langsung di sekolah.

Konsep model belajar flipped classroom pada dasarnya adalah apa yang dilakukan di kelas pada pembelajaran konvensional dikerjakan di rumah, sedangkan pekerjaan di rumah pada pembelajaran konvensional diselesaikan di kelas. Menurut Yulietri dkk (2015), flipped classroom adalah model dimana dalam proses belajar mengajar tidak seperti pada umumnya, yaitu dalam proses belajarnya pesrta didik mempelajari materi pelajaran di rumah sebelum kelas dimulai dan kegiatan belajar mengajar di kelas berupa mengerjakan tugas, berdiskuasi tentang materi atau masalah yang belum dipahami pesrta didik. Model pembelajaran flipped classroom terdiri dari berbagai type yang dibedakan berdasarkan bentuk tugas dan persiapan pembelajaran diantaranya: Traditional flipped, Mastery flipped, Peer Instruction flipped, Problem based learning flippe.

Model pembelajaran flipped classroom memiliki bebrapa langkah diantaranya tahap perisapan yaitu sebelum pertemuan tatap muka berlangsung guru melakukan pembelajaran seacar asyncronus terhadap siswa yang mendapatkan bagian belajar di rumah dengan memberikan materi dalam bentuk video pembelajaran, guru menyampaikan tujan pembelajaran serta Memberi tugas siswa untuk membuat rangkuman dari video yang akan dibahas pada pelaksanaan tatap muka terbatas. Kemudian tahapan kegiatan di kelas yaitu dilakukan untuk siswa yang 
mendapatkan bagian tatap muka terbatas di kelas, guru secara syncronus merancang kegiatan yang disesuaikan dengan tahapn persiapan sebelumnya, kegiatan tersebut dapat diawali dengan Membahas video yang telah ditonton siswa dengan diskusi dan tanya jawab, dilanjutkan dengan penguatan konsep melalui tanya jawab tersebut kegiatan pembelajaran di kelas dapat dilanjutkan dengan membagi poeserta didik secara berkelompok yang terdiri dari 2-4 orang kemudian diberikan lembar kerja peeserta didik, disini guru berperan sebagai fasilitator agar peserta didik mampu menuliskan ide atau gagasanya terkait masalah yang diberikan dilanjutkan dengan memberkan evalusai pemahaman peserta didik sebagai penilaian.

Keunggulan model pembelajaran flipped classroom Menurut Ulfa (2014) kelebihan flipped classroom adalah; 1. Siswa dapat mengulang-ulang materi tersebut hingga ia benar-benar paham materi, tidak seperti pada pembelajaran biasa apabila murid kurang mengerti maka guru harus menjelaskan lagi hingga. 2. Siswa dapat mengerti siswa dapat mencari informasi dari manapun yang mendukung materi tersebut. 3. Efisien, karena siswa diminta untuk mempelajari materi di rumah dan pada saat di kelas, siswa dapat lebih memfokuskan kepada kesulitannya dalam memahami materi ataupun kemampuannya dalam menyelesaikan soal-soal berhubungan dengan materi tersebut.

Berdasarkan uraian di atas dapat disimpulkan bahwa kelebihan strategi flipped classroom adalah siswa lebih leluasa untuk belajar mandiri di rumah dan dapat mengulangngulang mempelajari materinya hingga siswa paham dan siswa lebih bertanggung jawab atas apa yang sudah dipelajari mandiri di rumah sehingga siswa lebih matang dan siap saat masuk kelas dan pembelajaran dimulai. Hal ini dapat mengoptimalisasi pembelajaran tatap muka terbatas karena dengan keterbatasan kegiatan pembelajaran di sekolah itu tidak berarti mnegurangi keutuhan kesempatan peserta didik dalam menerima pembelajaran karena siswa sudah punya 
pengetahuan awal sebelum masuk kelas dan bisa bertanya saat ada bagian materi yang belum dipahami yang butuh penjelasan dari guru sehingga pembelajaran akan lebih optimal.

\section{Daftar Pustaka}

Yulietri, F., Mulyoto dan Agung, Leo. 2015. Model Flipped Classroom dan Discovery Learning Pengaruhnya Terhadap Prestasi Belajar Matematika Ditinjau dari Kemandirian Belajar. Jurnal Teknologi Pendidikan Pasca Sarjana UNS, Vol.13, No.2.

Ulfa (2014 Januari 05). Strategi Flipped Classroom. https://nurfitriyanaulfamath.wordpress/2014/01/05/ strategi-flipped-classroom/

Yulietri, F., Mulyoto dan Agung, Leo. 2015. Model Flipped Classroom dan Discovery Learning Pengaruhnya Terhadap Prestasi Belajar Matematika Ditinjau dari Kemandirian Belajar. Jurnal Teknologi Pendidikan Pasca Sarjana UNS, Vol.13, No.2 


\title{
OPTIMALISASI PENGEMBANGAN DIRI SISWA DI TENGAH PANDEMI COVID-19 DENGAN MADING DIGITAL
}

\author{
Dintya Ayu Purika, M.Pd. ${ }^{10}$ \\ (SMA Negeri 1 Parenggean)

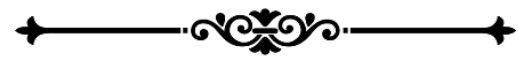

"Transisi majalah dinding konvensional ke majalah dinding digital di SMA Negeri 1 Parenggean membuahkan hasil yang positif di tengah pembelajaran tatap muka terbatas yang bermanfaat untuk menjaring siswa-siswi yang mempunyai potensi dalam bidang penulisan kreatif"

$\mathrm{M}$ asa Pandemi Covid-19 membuat pola pendidikan khususnya di SMA Negeri 1 Parenggean, Kalimantan Tengah, berubah. Semula proses belajar mengajar dilakukan dengan tatap muka, tetapi kini proses belajar mengajar dilakukan secara tatap muka terbatas dengan pembagian dua kelompok belajar untuk setiap kelasnya, sedangkan jumlah kelas di sini sebanyak 24 kelas yang diisi 800 siswa. Pembagian dua kelompok belajar ini, yakni sift offline dan online. Berbicara tentang pembelajaran jarak jauh dan tatap muka terbatas dengan memanfaatkan jaringan internet, serta

10 Penulis lahir di Sukoharjo, Jawa Tengah, 24 September 1989. Penulis merupakan guru berstatus CPNS mata pelajaran Bahasa Indonesia di SMA Negeri 1 Parenggean, Kalimantan Tengah. Penulis menyelesaikan gelar Pendidikan Bahasa dan Sastra Indonesia di Universitas Sarjanawiyata Tamansiswa Yogyakarta (UST), dan menyelesaikan gelar Magister Pendidikan Bahasa Indonesia di Universitas Sebelas Maret Surakarta (UNS). 
teknologi informasi dan komunikasi (TIK), dari sisi kebermanfaatan, sebenarnya telah memulai proses transisi pendidikan di tanah air kearah digitalisasi. Akan tetapi, tidak semua wilayah di Kecamatan Parenggean, Kotawaringin Timur, Kalimantan Tengah. Mempunyai akses internet yang lancar, misalnya di area pedalaman atau di dalam perusahaan Kelapa Sawit yang ada di sini. Hal ini juga menjadi kendala bagi guru-guru di Kalimantan Tengah khususnya Parenggean. Apalagi setiap harinya harus meng-handle dua kelompok belajar sekaligus, yakni kelompok offline dan online.

Layaknya dalam kondisi normal, kegiatan siswa tak hanya intrakulikuler saja, namun ekstrakulikuler atau pengembangan diri harus tetap jalan, sehingga siswa tetap mendapatkan ruang untuk berekspresi sesuai dengan bakat dan minatnya. Selain hal itu, proses belajar mengajar baik itu intrakulikuler maupun ekstrakulikuler pasti ada yang membutuhkan praktik secara langsung, hal ini juga terhambat. Sedangkan di tengah pembelajaran tatap muka terbatas seperti saat ini untuk menkonversi kegiatan pengembangan diri menjadi tantangan tersendiri, karena seperti kita ketahui bahwa output ekstrakulikuler adalah hasil karya.

Sesuai dengan keputusan bersama di SMA Negeri 1 Parenggean, bahwa sebagai guru pembina ektrakulikuler di tengah pandemi Covid-19, harus mempunyai gagasan solusi untuk menggerakan ekstrakulikuler supaya tetap berjalan dengan lancar. Oleh karena itu, penulis sebagai guru Bahasa Indonesia yang diberikan tugas untuk membina penulisan kreatif di majalah dinding sekolah, telah mencari solusi, yakni dengan mengubah penulisan kreatif mading dari konvensional menjadi majalah dinding (Mading) digital secara online .

Hal ini juga sekaligus jadi motivasi penulis untuk mengembangkan potensi diri ke arah digitalisasi. Tidak mudah mengajak siswa-siswi di SMA Negeri 1 Parenggean untuk mengelola mading sekolah secara online, banyak 
kendala antara lain; tidak semua siswa mempunyai laptop, siswa belum menguasai aplikasi power point yang digunakan untuk media pembuatan mading, siswa belum menguasai aplikasi untuk editing video, dan yang paling sulit adalah siswa lebih memilih main dengan teman sebayanya atau ke kebun kelapa sawit membantu orangtua bahkan ada yang sambil bekerja paruh waktu daripada mengikuti ekstrakulikuler mading digital.

Menurut Sefi dan Fadillah (2021: 06), untuk mengembangkan kemampuan siswa dalam kegiatan membaca dan menulis, guru dapat memotivasi dan memfasilitasi siswa untuk melakukan publikasi karya tulis ke berbagai media. Beberapa macam media bisa menjadi pilihan: 1) media kertas/cetak (koran, majalah, mading sekolah, maupun mading kelas, buletin sekolah, dan buku kumpulan karya); 2) media siar, misal radio, televisi; atau 3) media daring (blog, vlog, facebook, twitter atau instagram dan lainnya).

Pelaksanaan kegiatan ekstrakulikuler sendiri tidak lepas dari amanah Undang-Undang Nomor 20 Tahun 2003 tentang Sistem Pendidikan Nasional yang menyebutkan bahwa pendidikan nasional bertujuan untuk berkembangnya potensi peserta didik agar menjadi manusia yang beriman dan bertakwa kepada Tuhan Yang Maha Esa, berakhlak mulia, sehar, berilmu, cakap, kreatif, mandiri, dan menjadi warga negara yang demokratis serta bertanggung jawab. Pengembangan diri potensi peserta didik sebagaimana dimaksud dalam tujuan pendidikan nasional tersebut dapat diwujudkan melalui kegiatan intrakurikuler dan ekstrakulikuler. Turunan dari Undang-undang SISDIKNAS tersebut adalah Permendikbud No.62 tahun 2014 tentang kegiatan ekstrakurikuler. Selain sebagai ajang penyaluran ekspresi peserta didik terkait dengan bakat dan minatnya, kegiatan ekstra kurikululer juga bisa dimanfaatkan untuk ajang peningkatan citra sekolah dalam kaitannya dengan 
peraihan medali atau piala dalam setiap event kejuaraan yang diselenggarakan pihak internal ataupu eksternal.

Pada praktiknya, penulis sebagai pembina penulisan kreatif mading digital di SMA Negeri 1 Parenggean, harus menggerakan mading digital ini dimulai dari awal, yakni dengan proses tahapan yang tidak singkat. Siswa-siswi terlebih dahulu diberikan sosialisasi mengenai pergantian mading secara konvensional ke mading digital online melalui grup Whatsapp kelas dan diberitahu bahwa mading digital akan ditertibkan melalui channel youtube khusus mading digital yang dikelola oleh guru pembina. Setiap edisi mading diberikan tema yang disusun dalam dummy (susunan representasi yang akan diproduksi) yang sebelumnya dibuatkan oleh guru pembina, masing-masing tema sesuai event pada bulan tersebut, misal edisi di bulan Oktober 2021 lalu, dengan tema "Aku Cinta Indonesiaku". Dalam tema tersebut, siswa bebas memilih jenis karya yang akan dibuat, misalnya puisi, pantun, poster maupun tips yang bersifat informatif.

Sebagai guru yang membimbing, penulis mengajarkan pada mereka memanfaatkan aplikasi power point untuk mendesain karya tulis siswa-siswi. Dengan power point akan lebih mudah memberikan efek dan animasi bergerak. Diharapkan bisa menarik perhatian siswa untuk antuasias melihat hasil karyanya bila diterbitkan. Sedangkan untuk pengumpulan hasil karya mading siswa, file dikirim melalui aplikasi google classroom, baik dalam format JPG maupun PDF.

Hasil yang dikirim melalui aplikasi google classroom, kemudian diunduh dan di-import ke power point. Apabila semua karya tulis yang telah disortir selesai didesain pada power point, kemudian disimpan dalam format video, barulah di-edit kembali melalui aplikasi edit video, yakni Wondershare Filmora. Sedangkan untuk proses tahapan terakhir, yakni unggah ke channel youtube "mading smansapar2021" yang dikelola oleh penulis selaku guru pembina. 
Hasil dari transisi majalah dinding konvensional ke majalah dinding digital di SMA Negeri 1 Parenggean, cukup membuahkan hasil yang positif di tengah pembelajaran tatap muka terbatas seperti sekarang ini. Kegiatan ini juga sangat bermanfaat untuk menjaring siswa-siswi yang mempunyai potensi dalam bidang penulisan kreatif.

Pandemi Covid-19 tidak menyurutkan para abdi negara khususnya guru-guru di Kecamatan Parenggean, Kalimantan Tengah untuk terus berkarya dan melayani masyarakat khususnya peserta didik.

\section{Daftar Pustaka}

Aulia, Fadillah Tri dan Sefi Indra Gumilar. 2021. Cerdas Cergas Berbahasa dan Bersastra Indonesia Untuk SMA/SMK. Jakarta: Pusat Kurikulum dan Perbukuan Badan Penelitian dan Pengembangan dan Perbukuan Kementerian Pendidikan, Kebudayaan, Riset dan Teknologi.

Jaringan Dokumentasi dan Informasi Hukum BPK RI. 2003. Undang-Undang (UU) Tentang Sistem Pendidikan Nasional.

https://peraturan.bpk.go.id/Home/Details/43920/uuno-20-tahun-2003. Diunduh pada tanggal 18 November 2021 


\section{BAB II}

\section{SISTEM MANAJEMEN PENDIDIKAN}

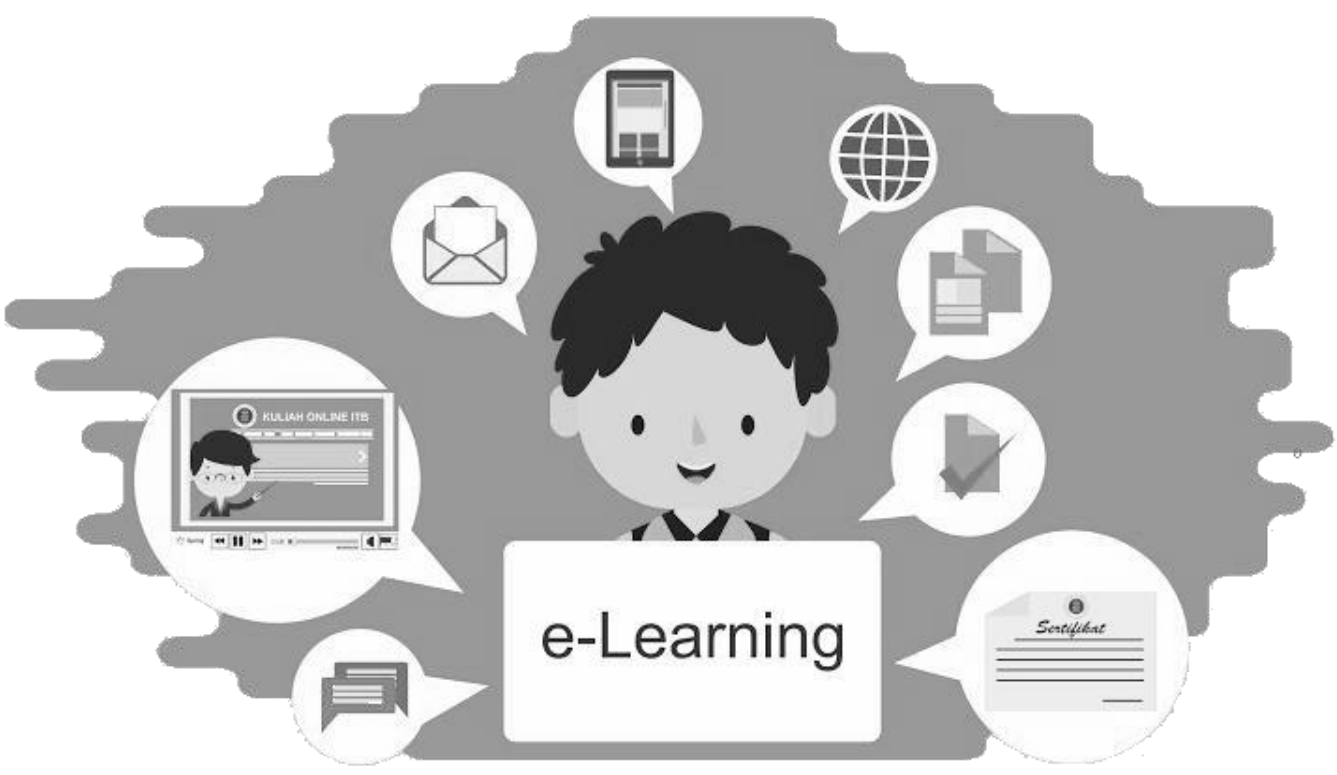




\title{
PERAN KETERAMPILAN MANAJERIAL KEPALA SEKOLAH DALAM PENGELOLAAN PEMBELAJARAN PASCA PANDEMI
}

\author{
Dr. Karwanto, M.Pd. ${ }^{11}$ \\ (Universitas Negeri Surabaya)

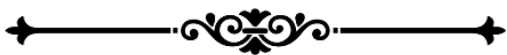

"Keterampilan manajerial kepala sekolah dalam upaya mengelola pembelajaran pasca pandemi dengan mengedepankan pada komunikasi, koordinasi, kolaborasi, dan sinergi untuk meningkatkan dan mengembangkan pembelajaran pasca pandemi yang menyenangkan dalam mewujudkan prestasi akademik dan non akademik peserta didik yang tinggi dan kompetitif"

\section{Pendahuluan}

Deran keterampilan manajerial kepala sekolah sangat penting dalam menata aspek manusia dan aspek non manusia, termasuk dalam mengelola pembelajaran pasca pandemi. Keterampilan manajerial kepala sekolah, yaitu keterampilan kepala sekolah dalam menjabarkan dan

\footnotetext{
${ }^{11}$ Penulis lahir di Indramayu Jawa Barat, 16 Mei 1977. Penulis merupakan Dosen Tetap Jurusan Manajemen Pendidikan Fakultas Ilmu Pendidikan Universitas Negeri Surabaya (UNESA. Penulis menyelesaikan gelar Sarjana di IAIN Walisongo (Universitas Islam Negeri Walisongo) Semarang Jurusan Pendidikan Agama Islam, Program Minor Pendidikan Matematika (2000), Program Magister Program Studi Manajemen Pendidikan di Pascasarjana Universitas Negeri Semarang (2004) dan Program Doktor Program Studi Manajemen Pendidikan di Pascasarjana Universitas Negeri Malang (UM) (2009).
} 
menterjemahkan konsep-konsep manajemen dalam tugas dan pekerjaannya di sekolah, dan mengaplikasikannya ke dalam tugas nyata sehari-hari dengan cara yang tepat. Katz (Peterson \& Van Fleet, 2004), percaya bahwa keterampilan manajerial bukanlah ciri-ciri kepribadian bawaan. Keterampilan kepala sekolah harus dikembangkan dengan menyediakan seperangkat pengetahuan manajerial dan metode untuk mengakses informasi. Kenyataan di lapangan menunjukkan bahwa keterampilan manajerial kepala sekolah dalam mengelola pembeajaran pasca pandemi benar-benar dituntut dan membutuhkan seni dalam proses pengelolaannya. Banyaknya sekolah yang dilihat dari pengelolaan masih perlu dikuatkan dan tidak mendapatkan peserta didik, semua ini tidak terlepas dari peran manajerial kepala sekolah sebagai pengelola sekolah. Hasil penelitian (Amalyah et al., 2021) menunjukkan bahwa dalam proses pembelajaran, peran kepala sekolah sangat penting. Kepala sekolah sebagai pintu gerbang tumbuh kembang anak dan pelestarian konsep hidup tentunya membutuhkan pengelolaan yang profesional. Peran kepala sekolah sebagai administrator saat terjadi pandemi COVID-19, kepala sekolah telah melaksanakan tugasnya dengan baik. Selama pandemi Covid 19, peran kepala sekolah dalam penyelenggaraan pendidikan menjadi prioritas untuk perencanaan rencana intervensi, pengelolaan anggaran, pelaksanaan rencana dan penggunaan anggaran.

Hasil penelitian senada yang dilakukan (Djumiko et al., 2020) menunjukkan bahwa upaya yang dilakukan secara intern oleh kepala sekolah antara lain optimalisasi layanan pembelajaran daring, optimalisasi layanan administrasi sekolah dan optimalisasi pemenuhan serta perawatan fasilitas sekolah. Selanjutnya, hasil penelitian (Saifulloh \& Darwis, 2020) sampai pada simpulan yang menyatakan bahwa peran kepala sekolah sebagai pemimpin pembelajaran di sekolah dan peran guru sangat dibutuhkan dalam memanage atau mengelola pembelajaran mulai dari perencanaan (planning), 
pengorganisasian (organizing), pelaksanaan (actuating) dan evaluasi (evaluating) dalam rangka meningkatkan efektivitas proses belajar mengajar di masa pandemi covid 19 saat ini, baik implementasi pembelajaran jarak jauh (PJJ) dalam jaringan (daring) maupun luar jaringan (luring). Hasil penelitian (Tonidandel et al., 2012); (Mehralian et al., 2020); (Popescu et al., 2020); (Bodziany et al., 2021); (Vrontis et al., 2021); (Ratnawati et al., 2021), menunjukkan bahwa. Keempat dimensi keterampilan manajerial yaitu: (1) technical skill; (2) administrative skill; (3) human skill; and (4) citizenship behavior, adalah prediktor penting yang signifikan dari efektivitas manajer. Berdasarkan hasil penelusuran literatur di atas, nampaknya belum banyak kajian terkait dengan peran keterampilan manajerial kepala sekolah dalam mengelola pembelajaran pasca pandemi. Penelitian sebelumnya lebih banyak terkait dengan keterampilan manajerial kepala sekolah dalam meningkatkan kinerja guru. Belum ada kajian yang bertujuan untuk mengetahui peran keterampilan manajerial kepala sekolah dalam mengelola pembelajaran pasca pandemi. Oleh karena itu, dapat dibuat proposisi yaitu jika kepala sekolah memiliki peran keterampilan manajerial yang menonjol maka kepala sekolah akan mampu mengelola pembelajaran pasca pandemi. Yang menjadi pertanyaan adalah bagaimana peran keterampilan manajerial kepala sekolah dalam mengelola pembelajaran pasca pandemi. Dalam tulisan ini dibahas hal-hal pokok sebagai berikut: (a) konsep dasar keterampilan manajerial kepala sekolah; (b) peran keterampilan manajerial kepala sekolah dalam mengelola pembelajaran pasca pandemi.

\section{Konsep Dasar Keterampilan Manajerial Kepala Sekolah}

Untuk memahami konsep dasar keterampilan manajerial kepala sekolah, berdasarkan kajian Hersey \& Blanchard (1982), ada tiga keterampilan-keterampilan yang diperlukan untuk melaksanakan proses manajemen yaitu: keterampilan teknis (technical skill), keterampilan manusiawi (human skill) dan keterampilan konseptual (conceptual skill). Ketiga 
keterampilan di atas dapat dijelaskan sebagai berikut. (a) keterampilan teknis (technical skill) yaitu kemampuan menggunakan pengetahuan, metode, teknik, dan peralatan yang diperlukan untuk melaksanakan tugas tertentu yang diperoleh dari pengalaman, pendidikan, dan latihan (training); (b) keterampilan manusiawi (human skill) yaitu kemampuan bekerja sama dengan dan melalui orang lain, yang mencakup pemahaman tentang motivasi dan penerapan kepemimpinan yang efektif; (c) keterampilan konseptual (conceptual skill) yaitu kemampuan untuk memahami kompleksitas organisasi dan penyesuaian bidang-bidang pada unit kerja masing-masing ke dalam bidang operasi organisasi secara menyeluruh. Keterampilan ini memungkinkan seseorang bertindak selaras dengan tujuan organisasi secara menyeluruh daripada hanya atas dasar tujuan dan kebutuhan kelompoknya sendiri. Analisis dari masing-masing keterampilan tersebut mengungkapkan bahwa pada tingkatan apapun pemimpin harus lebih banyak menekankan perhatiannya pada keterampilan manusiawi (emphasis on human skills). Mengapa demikian? Karena pekerjaan seorang manajer selalu dihadapkan pada unsur manusia dalam organisasi yang punya dinamika tertentu dan sekaligus menjadi faktor penentu bagi keberhasilan misi organisasi

\section{Peran Keterampilan Manajerial Kepala Sekolah Dalam Mengelola Pembelajaran Pasca Pandemi.}

Keberhasilan kepala sekolah dalam meningkatkan kinerja sekolah tergantung pada peran keterampilan manajerial yang dimainkan oleh kepala sekolah. Kepala sekolah yang professional, visioner, kreatif, inovatif, responsif dan adaptif serta connected terhadap perubahan-perubahan pacsa pandemi, diharapkan mampu melakukan peran keterampilan manajerial yang berbeda dalam keadaan yang berbeda dalam mengelola pembelajaran. Dengan demikian, agar sekolah berhasil dalam mewujudkan kinerjanya, kepala sekolah harus melaksanakan peran manajerialnya dengan sangat baik. Peran manajerial kepala sekolah sangat penting untuk 
efektivitas sekolah. Kepala sekolah harus didukung oleh pendidik dan tenaga kependidikan serta peran serta masyarakat dalam mengelola pembelajaran pasca pandemi. Kepala sekolah sebagai manajer dalam organisasi sekolah, sangat penting perannya dalam mengelola perubahanperubahan yang sangat dinamis, hal inilah yang merupakan fungsi penting dari peran manajerial. Peran keterampilan manajerial kepala sekolah dalam mengelola pembelajaran pasca pandemic dapat dijelaskan sebagai berikut. Pertama, memberikan dukungan dan mampu mengelola pembelajaran pasca pandemi. Kedua, memfasilitasi perubahan yang berarti pasca pandemi. Ketiga, melakukan supervisi secara terencana, terprogram dan berkesinambungan. Keempat, melakukan evaluasi proses dan evaluasi hasil terkait dengan pembelajaran pasca pandemi. Kelima, membangun dan memelihara tim pemenang atau tim sukses dalam mengawal pembelajaran pasca pandemi. Keenam, mengembangkan sumber daya manusia (pendidik dan tenaga kependidikan) melalui kegiatan diklat dan non diklat terkait pengelolaan pembelajaran pasca pandemi. Ketujuh, melakukan penilaian terhadap guru dan tenaga kependidikan. Kedelapan, monitoring pelaksanaan kebijakan pendidikan terkait pengelolaan pembelajaran pasca pandemi. Kesembilan, monitoring kemajuan peserta didik. Kesepuluh, mengelola kurikulum dan pembelajaran. Kesebelas, mempromosikan iklim sekolah yang positif (Mazibuko, 2007). Hasil penelitian ini dapat diimplementasikan oleh kepala sekolah yang memiliki keterampilan manajerial yang menonjol dalam upaya mengelola pembelajaran pasca pandemi dengan mengedepankan pada komunikasi, koordinasi, kolaborasi/kerjasama, dan sinergi dengan guru dan tenaga kependidikan serta stakeholders pendidikan dan peran serta masyarakat dalam upaya mengelola, meningkatkan dan mengembangkan pembelajaran pasca pandemi yang menyenangkan dalam mewujudkan prestasi akademik dan non akademik peserta didik yang tinggi dan kompetitif. 


\section{Daftar Pustaka}

Amalyah, S., Febriyanti, E., Wandika, H., \& Najmudin, N. (2021). Peran Kepala Sekolah Dasar Negeri dalam Penyelenggaraan Pendidikan Pada Masa Pandemi Covid-19. Jurnal Pendidikan Indonesia, 2(5), 894-903. https://doi.org/10.36418/japendi.v2i5.174

Bodziany, M., Ścibiorek, Z., Zamiar, Z., \& Visvizi, A. (2021). Managerial Competencies \&amp; Polish SMEs' Response to the COVID-19 Pandemic: An Insight. Sustainability, 13(21), 11864. https://doi.org/10.3390/su132111864

Djumiko, D., Fauzan, S., \& Jailani, M. (2020). Panduan Kepala Sekolah Untuk Mengelola Sekolah Pada Masa Pandemic Covid-19. Pedagogik: Jurnal Pendidikan, 15(2), 56-69. https://doi.org/10.33084/pedagogik.v15i2.1701

Hersey, P \& Blanchard, K.H. 1982. Management of Organizational Behavior: Utilizing Human Resources. (2nd Edition). New Jersey: Englewood Cliffs, PrenticeHall, Inc.

Mazibuko, S.P., (2007). The managerial role of the principal in whole-school evaluation in the context of disadvantaged schools in Kwazulu-Natal (Doctoral dissertation, University of South Africa).

Mehralian, G., Peikanpour, M., Rangchian, M., \& Aghakhani, H. (2020). Managerial skills and performance in small businesses: the mediating role of organizational climate. Journal of Asia Business Studies, 14(3), 361-377. https://doi.org/10.1108/JABS-02-2019-0041

Peterson, T. O., \& Van Fleet, D. D. (2004). The ongoing legacy of R.L. Katz. Management Decision, 42(10), 1297-1308. https://doi.org/10.1108/00251740410568980

Popescu, L., Iancu, A., Avram, M., Avram, D., \& Popescu, V. (2020). The Role of Managerial Skills in the Sustainable Development of SMEs in Mehedinti County, Romania. 
Sustainability,

https://doi.org/10.3390/su12031119

Ratnawati, R., Rokhman, M. T. N., \& Rahayu, Y. N. (2021). Managerial Ability As An Effort To Improve Sme Performance Through Competitive Advantage In The Pandemic Time Covid 19. Jurnal Aplikasi Manajemen, 19(2), 363-375. https://doi.org/10.21776/ub.jam.2021.019.02.12

Saifulloh, A. M., \& Darwis, M. (2020). Manajemen Pembelajaran dalam Meningkatkan Efektivitas Proses Belajar Mengajar di Masa Pandemi Covid-19. Bidayatuna: Jurnal Pendidikan Guru Mandrasah Ibtidaiyah, 3(2), 285. https://doi.org/10.36835/bidayatuna.v3i2.638

Tonidandel, S., Braddy, P. W., \& Fleenor, J. W. (2012). Relative importance of managerial skills for predicting effectiveness. Journal of Managerial Psychology, 27(6), 636-655.

https://doi.org/10.1108/02683941211252464

Vrontis, D., El Chaarani, H., El Abiad, Z., El Nemar, S., \& Yassine Haddad, A. (2021). Managerial innovative capabilities, competitive advantage and performance of healthcare sector during Covid-19 pandemic period. Foresight, ahead-of-p(ahead-of-print).

https://doi.org/10.1108/FS-02-2021-0045 


\title{
TRANSFORMASI DAN MASA DEPAN PENDIDIKAN INDONESIA PASCAPANDEMI COVID-19
}

\author{
Dr. Abdul Malik Iskandar, S.Ag, M.Si. ${ }^{12}$ \\ (Universitas Magerezky)

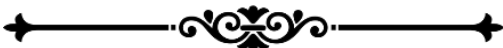

"Transformasi dalam pendidikan harus selalu sejalan dengan konteks kehidupan yang sedang dan akan terjadi"

\section{Pendahuluan}

Derguruan tinggi, baik sebagai institusi maupun para - akademisinya, memiliki pengaruh besar untuk mengarahkan cara pandang masyarakat sehingga disebur agen perubahan. Oleh karena itu, kampus dan sivitasnya perlu bersuara nyaring menyuarakan agenda mengedit kembali dunia pendidikan kita. Kata mengedit ulang itulah sebagaian makna terkandung dalam kata transformasi.

Pengalaman mengarungi pembelajaran full daring (dalam jaringan) pada semua jenjang pendidikan, mulai dari tingkat pendidikan dasar sampai pendidikan tinggi di tengah terjangan pandemi covid-19 selama kurang lebih dua tahun, tepatnya sejak bulan Maret 2020 - November 2021 telah menimbulkan dampak luar biasa pada tingkat ketercapaian tujuan pembelajaran dan tujuan pendidikan nasional.

12 Penulis lahir di Kampiri, Desa Cipta, 14 Oktober 1969. Penulis merupakan Dosen Universitas Megarezky (UNIMERZ). Penulis menyelesaikan gelar Sarjana Tadris Pendidikan Bahasa Inggris UIN Alauddin Makassar (1996), menyelesaikan gelar Magister Ilmu Komunikasi UNHAS (2009), dan menyelesaikan gelar Doktor Sosiologi UNM (2015). 
Pembelajaran Tatap Muka Terbatas (PTMT) sebagai kebijakan baru yang ditempuah pemerintah dan diimplematasikan di sekolah. Implementasi tiap sekolah berbeda-beda. Ada yang membuat sesi 1 dan sesi 2, ada pula bersamaan, offline dan sebagian online. Terkait ini, penulis berkesempatan mewawancarai beberapa guru dan murid di SMA Negeri 12 di Makassar dan hasilnya, persepsi mereka baik guru dan murid tidak menyukai metode ini dengan alasan: proses pembelajaran tak bergairah, tujuan pembelajaran tak tercapai, interkasi sosial sangat terbatas, tak ada jaringan dan paket data, kesulitan mengajar ada off ada online (wawancara, 15/11/2021).

Dampak yang paling menonjol dan nyata adalah ketidaktersediaan infrastrukutr informasi teknologi (IT) dan Sumber Daya Manusia pendidik di semua jenjang pendidikan. Akibatnya, sektor pendidikan dapat dikatakan sebagai salah sektor yang paling berdampak selain ekonomi dan kesehatan. Sistem pendidikan kita selama ini, tidur nyenyak dalam balutan busana konvensional tatap muka sebagai menu pavorit dan dengan sedikit mengandalkan media pembelajaran terbatas laptop, serta materi power point yang tak pernah mengalami update lagi.

Transformasi diartikan sebagai tata cara menata ulang. Menurut Kamu Besar Bahasa Indonesia (KBBI) Transformasi didefinisikan perubahan rupa (bentuk, sifat, fungsi, dan sebagainya), perubahan struktur gramatikal menjadi struktur gramatikal lain dengan menambah, mengurangi atau menata kembali unsur-unsurnya.

Sekolah masa depan yang menyenangkan dan relevan disiapkan sebagai arah transformasi sistem pendidikan Indonesia dengan semangat Merdeka Belajar. Perubahan harus dijalankan secara paralel sambil memastikan fondasi untuk transformasi sistem pendidikan masa depan siap, kokoh, dan berkelanjutan. Menurut Mendikbud dan Ristek, Nadiem Makarim (Harian Kompas, Selasa (2/11/2021) lima tahun ini menjadi masa untuk menetapkan dan mengatur 
perubahan arah pendidikan agar tidak salah arah. Dalam 10 15 tahun ke depan, perubahan sistem pendidikan yang mengikuti standar internasional serta sekolah yang menyenangkan dan relevan diyakini bakal mulai dirasakan dalam dalam mendukung pembangunan sumber daya manusia Indonesia yang unggul dan berkarakter.

Selanjtnya pemerintah menyiapkan sekitar 5000 percontohan sekolah penggerak masa depan. Di sekolah ini diterapkan piloting yang merupakan penyederhanaan dari kurikulum 2013. Pendekatan dalam kurikulum pun diubah, bukan lagi dari hasil pemikiran akademisi, melainkan dari guru dan untuk guru.

\section{Transformasi Pendidikan Pascapandemi}

Transformasi dalam pendidikan khususnya dalam hal infrastruktur informasi teknologi pendidikan, proses pembelajaran, isi kurikulum, mental guru, murid serta pemangku kepentingan tak terhindari lagi. Transformasi sebuah keniscayaan untuk masa depan pendidikan Indonesia. Transformasi konprehensif dan sistimatis sangat diperlukan abad ini. Tingkok telah memprediksi masa depan pendidikan puluhan tahun bahkan ratusan tahun silam bahwa on line course salah satu cara yang harus dilakukan untuk masa depan pendidikan tiongkok.

Perspektif penulis mengenai bidang-bidang yang menjadi inti yang dapat dilakukan transformasi antara lain:

\section{Transformasi mental pendidik dan peserta belajar}

Selama berpuluh-puluh tahun lamanya pendidik dan peserta didik tidur nyeyak dalam selimut tebal proses pembelajaran dalam ruang kelas fisik yang berukuran sempitdan kesan kumal dan coretan-coretan kotor di dinding. Ditambah lagi dengan mental pendidik dan murid yang memandang bahwa kehadiran teknologi pendidikan dianggap sebagai disrupsi dalam pembelajaran. Akibatnya guru dan murid tidak melek teknologi alias gagap teknologi. Sering disebut dalam ejekan seperti guru TBC alias tidak 
bisa komputer, guru nifas alias nihil fasilitas, guru kudis alias guru kurang disiplin.

Transformasi yang harus segera dilakukan pendidik adalah transformasi sikap mentalnya terhadap keahadiran teknologi. Berbagai riset menunjukkan bahwa hambatan besar proses pembelajaran virtual di tengah covid ini kemampuan teknologi para pendidik sangat rendah dan diperparah lagi dengan jangkauan internet sangat rendah dan terbatas.

Saat ini, diperlukan pergeseran paradigm lama dalam sistem pendidikan. Pendekatan yang dilakukan tidak lagi memaksakan semua sama, tetapi memberikan ruang fleksibilitas bagi guru, sekolah dan siswa untuk bergerak mencapai tujuan pendidikan. Aplikasi pendidikan banyak diluncurkan oleh pemerintah untuk mendukung proses pembelajaran tersebut. Nah di titik ini diperlukan kemahiran pada teknologi.

\section{Transformasi Ruang kelas}

Ruang Kelas adalah yaitu ruangan yang dibatasi oleh dinding, atau sekat, dan dipergunakan sebagai tempat belajar mengajar (Khatimah Nurul, 2015). Ruang Kelas adalah sejumlah pelajar yang sama-sama menempuh suatu tingkatan tertentu dalam sebuah lembaga pendidikan (Erwin Widiasworo).

Konteks ruang kelas sekarang tidak lagi selalu dimaknai ruang kelas sebagai fisik, dinding tebal dan ukuran tertentu, ada meja guru dan bangku siswa, ada gambar presiden dan wakil presiden, papan tulis kumuh. Ruang kelas sesungguhnya adalah sebagai sebuah sistem sosial yang memiliki bagian saling ada ketergantungan, misalnya guru, murid, orang tua, norma, dan masyarakat luas. Hal ini sebagaimana dikatakan Iskandar (2021) Ruang kelas konvensional terdiri dari beberapa elemen atau unsur yang saling berkaitan, tergantung dan mempengaruhi, yakni guru, murid dan manajemen sekolah. dan pendapat ini dikuatkan 
oleh Damsar (2011). Ruang kelas konvensional telah nyata bergeser ke ruang kelas dunia maya, baik bentuk dan fungsinya.

Proses bergesernya ruang kelas konvensional ke virtual atau on line leraning menegaskan bahwa proses pembelajaran dapat terjadi kapan dan di mana saja. Dan lebih menegaskan pula bahwa proses belajar mengajar tidak selalu berada ruang kelas mewah, nyaman dan berfasiltas lengkap. Sudah sekian lama pendidik dan peserta didik terlibat sangat lama dalam pendidikan konvensional. Konteks ruang kelas hari ini adalah ruangan kelas digitalisasi. Seluruh materi dan proses pembelajaran diletakkan di ruangan yang disebut ruangan elektronik, yang diakses kapan dan dimana saja.

\section{Transformasi mental pemangku kepentingan}

Ego struktural telah menjadi bagian kesemrautan penyususunan dan penetapan sistem pendidikan, diantaranya kurikulum dan diprediksi banyak pihak sarat dengan transaksional. Dominasi pemangku kepentingan dan elit dalam penyusunan kurikulum bagian nyata dari kurikulum kita.

Adalah persoalan mental para pejabat. Salah satu syarat mengubah kurikulum adalah kehadiran expert/ahli di bidang kurikulum. Kurikulum bukan asal jadi, tapi kerikulum benar-benar sebagai fasilitas untuk tujuan pendidikan nasional. Kurikulum yang memilki koneksitas lapangan kehidupan manusia. Itulah inti kurikulum.

\section{Transformasi kurikulum}

Ciri khas paling menonjol isi kurikulum dalam sistem pendidikan Indoensia saat ini adalah isinya cenderung seragam. Dalam semua aspek cenderung seragam, baik isi, metode, capaian pembelajaran, model, dan seterusnya. Ibarat menu makanan, menu ikan harus di makan oleh semua orang, padahal tidak semua orang menyukai ikan. 
Ada yang menyukai tahu, tempe, telur, daging dan sebagainya.

Inilah potret kurikulum kita selama ini. Sentralisasi kurikulum. Dibuat dan ditetapkan di ibu kota dan dimplementasikan di seluruh pelosok tanah air, bahkan di pelosok desa yang sangat terpencil sekalipun, tidak ada jaringan internet, diharuskan menerapkan kurikulum yang sama seperti diterapkan di ibu kota dengan fasilitas media pembelajaran lengkap. Kurikulum idealnya menganut pemetaan wilayah.

Kurikulum sejatinya berbasis dari aras paling bawah. Mislanya kurikulum untuk jenjang pendidikan SD/MI, SMP/Mts dan SMA/MA dibuat oleh guru untuk guru pula. Kalau selama ini, kurikulum selama ini dibuat oleh para akademisi dan pemangku kepentingan dari berbagai kalangan tanpa melibatkan para guru, sebab kurikulum harus memuat hajat kehidupan orang banyak dalam aspek kehidupan. Ironis, sebab guru merupakan garda terdepan pelaksanaan kurikulum.

\section{Prediksi Masa depan Pendidikan}

Isu pendidikan global terkini, termasuk Indonesia adalah kemampuan institusi pendidikan menyiapkan perangkat pembelajaran berupa Information Communication Technology (ICT) dalam bidang pendidikan. Fakta menunjukkan bahwa ketidaksiapan perangkat pembelajaran elektronik dan ketidakmampuan sumber daya manusia ini menyebabkan ketertinggalan dan kegagalan masif dalam dunia pendidikan kita saat ini.

Apa kecenderungan masa depan pendidikan saat ini ? pakar pendidikan dunia memprediksi masa depan pendidikan global merujuk pada indikator utama yaitu online course, guru dan murid bekerja pada teknologi baru, guru lebih banyak mengajar soft skill dari hard skill, media sosial sebgai tempat menyebarkan materi pembelajaran, isi kurikulum lebih 
dominasi praktis dari pada teori, mata kuliah komputer akan menjadi mata kuliah wajib (Boenjamin, 2014).

\section{Kesimpulan}

Transformasi dalam pendidikan harus selalu sejalan dengan konteks kehidupan yang sedang dan akan terjadi. Pendidikan adaptif dengan dunia industri. Pendidikan adaptif dengan kemajuan teknologi. Adaptif dengan kebutuhan kehidupan masyarakat. Singakt kata transformasi pendidikan mengikuti dan adaptif dengan perubahan.

\section{Daftar Pustaka}

Damsar. 2011. Pengantar Sosiologi Pendidikan, Jakarta: Penerbit PT Kencana

Iskandar, A Malik. 20210. Transformasi dunia pendidikan dalam Upaya Percepatana SDM Unggu, Tulungagung: Akademia Pustaka

Khatimah Nurul, A. W. 2015. Ruang kelas sebagai suatu sistem dalam menunjang proses belajar mengajar', Jurnal Sosialisasi Pendididkan Sosiollogi, (3), pp. 1-5.

Kamus Besar Bahasa Indonesia - edisi ke empat.

Setiawan, Boejamin, 2014. The Future of Academy-BusinessGovernment Collaboration in Innovation and Technology $(A B G C)$. 


\title{
BLENDED LEARNING SEBAGAI SOLUSI PEMBELAJARAN PASCA PANDEMI
}

\author{
Dr. Syarifuddin, M.Pd. ${ }^{13}$ \\ (Universitas Sriwijaya)
}

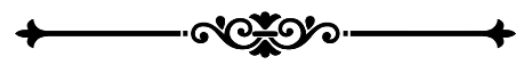

"Blended learning merupakan cara untuk mengintegrasikan penggunaan teknologi ke dalam pembelajaran untuk menciptakan lingkungan belajar yang tepat bagi setiap siswa di kelas yang memungkinkan adanya refleksi pembelajaran"

Dandemi Covid-19 memberikan dampak baik dari bidang Beberapa negara bahkan menutup sekolah dari tingkat dasar hingga perguruan tinggi sebagai upaya mencegah penyebaran Covid-19. Word healt Organization (WHO) memberikan intruksi kepada masyarakat untuk tidak melakukan kegiatan atau aktivitas yang akan menyebabkan kerumunan (Pranoto dan Adam Wahida, 2021).

Menteri Pendidikan dan Kebudayaan Republik Indonesia mengeluarkan surat ederan pada tanggal 24 Maret 2020 yaitu Nomor 4 Tahun 2020 tentang Pelaksanaan Kebijakan Pendidikan dalam Masa Darurat Penyebaran Covid. Surat

\footnotetext{
${ }^{13}$ Penulis lahir di Kota Lahat Sumatera Selatan pada tanggal 30 November 1984. Penulis merupakan koordinator program studi pendidikan sejarah FKIP (S1) Universitas Sriwijaya. Penulis menyelesaikan gelar Sarjana Pendidikan Sejarah di Universitas Sriwijaya, menyelesaikan gelar Magister Teknologi Pendidikan di Universitas Sriwijaya, dan menyelesaikan gelar Doktor Teknologi Pendidikan di Universitas Negeri Jakarta.
} 
edaran tersebut dijelaskan bahwa proses belajar dilaksanakan di rumah melalui pembelajaran daring atau jarak jauh dilaksanakan untuk memberikan pengalaman belajar yang bermakna bagi siswa. Belajar di rumah dapat difokuskan pada pendidikan kecakapan hidup antara lain mengenai pandemi Covid-19 (Afghani, 2020).

Pada masa pandemi Covid-19 memiliki salah satu alternatif pembejaran agar tetap berjalan yakni dilakukan secara online. Pembelajaran secara online adalah proses belajar-mengajar yang terhubung dalam jaringan internet dengan konektivitas, aksesibilitas, fleksibilitas, dan kemampuan yang akan menimbulkan berbagai jenis interaksi pembelajaran. Internet dan teknologi dibutuhkan pada masa pandemi karena mampu memberikan solusi penyampaian pengetahuan dalam pembelajaran yang dilaksanakan di kelas (Handarini et al., 2020).

Bidang teknologi informasi dan komunikasi (TIK) berkembang pesat memasuki abad ke-21. Perkembangan ini memberikan pengaruh yang besar dalam banyak aspek kehidupan, bahkan tingkah laku dan kegiatan manusia. Guru diminta untuk memilih model pembelajaran yang tertuju kepada semangat siswa untuk berpartisipasi aktif dalam kegiatan belajar yang menjadi pengalaman belajarnya. Pemilihan model pembelajaran yang digunakan di dalam kelas dapat mempengaruhi penguasaan topik dan hasil belajar siswa. Model pembelajaran yang telah dipilih dan diterapkan di dalam kelas dapat memberikan penguasaan topik sebagai hasil belajar.

Pemerintah mewajibkan seluruh institusi di Zona Hijau untuk melakukan pembelajaran tatap muka dengan selalu mematuhi protokol kesehatan dan menjaga jarak fisik. Pasca new normal, pembelajaran berbasis e-learning tidak dapat sepenuhnya mencapai tujuan pembelajaran, sehingga proses pembelajaran tidak cukup fokus pada pembelajaran online (elearning), tetapi melengkapi dengan pembelajaran tatap muka di kelas (Rohana \& Syahputra, 2021). Indonesia kini 
memasuki kehidupan baru sehingga pemerintah menginstruksikan masyarakat untuk menggunakan masker, sering mencuci tangan dan menjaga jarak (Fatimah, 2019).

Pembelajaran secara daring pada masa penyebaran Covid19 merupakan upaya agar proses pendidikan tetap berjalan dan dapat menjaga keamanan tenaga pendidik dan peserta didik. Pembelajaran daring yang efektif era new normal salah satunya menggunakan model Blended Learning. Blended learning merupakan model yang menggabungkan pelajaran tatap muka dengan pembelajaran daring (Dimhari, 2021). Blended Learning adalah cara baru pembelajaran yang dapat dilaksankan di dalam kelas dan online (Wardani, 2018).

Adapun penelitian yang pernah dilakukan yakni oleh Nunung Nurhadi berjudul " Blended Learning Dan Aplikasinya Di Era New Normal Pandemi Covid-19" dengan hasil pembahasan bahwa pembelajaran Blended di era new normal sebagai upaya mengurangi adanya perkumpulan. Namun, tidak mengurangi esensi kegiatan yang akan meningkatkan kompetensi sehingga terlaksananya sistem terpadu antara pembelajaran online dan tatap muka.

Blended learning merupakan proses pembelajaran yang menggunakan berbagai pendekatan, menggunakan berbagai media dan teknologi, serta menggabungkan strategi penyampaian pembelajaran dengan komputasi berbasis komputer secara langsung (offline) dan online (internet dan mobile learning). Materi pembelajaran yang diberikan melalui media ini meliputi grafik, teks, animasi, simulasi, audio dan video video (Rohana, 2020). Kombinasi efektif pengajaran tatap muka, di mana guru dan siswa bertemu tatap muka dan melalui media online yang dapat diakses setiap saat

Blended learning merupakan cara untuk mengintegrasikan penggunaan teknologi ke dalam pembelajaran untuk menciptakan lingkungan belajar yang tepat bagi setiap siswa di kelas. Blended learning memungkinkan refleksi pembelajaran (Priskawati, 2020) Model pembelajaran sesuai 
dengan perkembangan zaman, namun di masa pandemi Covid19 pasca new normal, pendidik secara cermat memilih model pembelajaran yang efektif dan efisien untuk memenuhi tujuan pembelajaran. di era revolusi industri 4.0. Peserta didik setidaknya dapat mengubah cara belajar, baik dengan cara memperoleh informasi, sinkronisasi informasi maupun pemutakhiran informasi melalui pendidikan berbasis teknologi informasi untuk mencapai tujuan pembelajaran (Rohana \& Syahputra, 2021).

Pengembangan blended learning secara teknik yakni kombinasi model pembelajaran yang menerapkan model tatap muka yang dilaksanakan baik dalam konteks online maupun offline. Strategi pengorganisasian dan penyampaian pengajaran tidak hanya memainkan peran penting dalam proses pembelajaran, tetapi kualitas pengajaran juga memainkan peran dinamis dalam pembelajaran siswa, yang mungkin tidak mencapai hasil yang diinginkan dan komunikasi dan interaksi antara siswa. Siswa. dan guru dilakukan secara berulang-ulang atau terus menerus. Kesinambungan baik di dalam maupun di luar sekolah yang akan membangun semangat sosialisasi yang baik (Hikmah \& Chudzaifah, 2020).

Tujuan blended learning yakni: untuk membantu guru berkembang lebih baik dalam proses pembelajaran, dalam hal gaya belajar dan preferensi atau pilihan pembelajaran; memberi guru kesempatan nyata dan praktis untuk belajar mandiri, memperkaya, dan berkelanjutan; meningkatkan fleksibilitas penjadwalan untuk guru, mengintegrasi aspek terbaik dari tatap muka dan online. Pelajaran langsung yakni melibatkan siswa dalam pengalaman interaktif. Serta melibatkan guru. Sedangkan kelas online melibatkan siswa dengan konten multimedia yang kaya pengetahuan kapan saja dan di mana saja selama guru memiliki akses internet (Rohana, 2020).

Karakteristik yang paling umum dikutip oleh Egbert dan Hanson Smith (1999): (1) Peserta didik mempunyai 
kesempatan untuk bersosialisasi dan bernegosiasi. (2) Peserta didik mempunyai waktu dan umpan balik yang cukup. (3) Siswa dibimbing untuk menyaksikan keseluruhan proses pembelajaran. (4) Siswa berada dalam kondisi dan situasi yang ideal, yaitu berkurangnya tingkat stres atau kecemasan. Blendedn Learning mendukung semua manfaat pembelajaran online termasuk penghematan biaya, efisiensi waktu, dan memastikan lokasi yang nyaman bagi siswa. Oleh karena itu, yang terpenting adalah pemahaman setiap individu dan motivasinya (Nurhadi, 2020).

Penggunaan model pembelajaran blended learning dapat dirumuskan sebagai berikut: (1) membantu siswa berkembang lebih baik dalam proses pembelajaran sesuai dengan gaya belajar dan preferensi belajar; (2) memberikan kesempatan nyata dan praktis bagi guru dan siswa untuk belajar mandiri, bermakna, dan berkembang dan (3) meningkatkan fleksibilitas jadwal bagi siswa, menggabungkan aspek terbaik dari pembelajaran tatap muka dan online (Ni'matul Khoiroh, 2017).

Adapun kelebihan dari blended learning yang diungkapkan oleh Kusairi yaitu: (Wardani,2018).

1. peserta didik leluasa untuk mempelajari materi pelajaran secara mandiri dengan memanfaatkan materi materi yang tersedia secara online

2. peserta didik dapat berkomunikasi/berdiskusi dengan pengajar atau peserta didik lain yang tidak harus dilakukan saat di kelas (tatap muka)

3. kegiatan pembelajaran yang dilakukan peserta didik di luar jam tatap muka dapat dikelola dan dikontrol dengan baik oleh pengajar

4. pengajar dapat menambahkan materi pengayaan melalui fasilitas internet 
5. pengajar dapat meminta peserta didik membaca materi atau mengerjakan tes yang dilakukan sebelum pembelajaran

Lembaga pendidikan formal berperan penting dalam adaptasi peserta didik, sehingga menjadi generasi yang tidak ketinggalan dalam menghadapi perubahan teknologi yang sedang berkembang pesat. Sekolah diharuskan untuk mengikuti perkembangan teknologi agar dapat menghasilkan lulusan yang berkompeten dalam pengetahuan, sikap dan keterampilan. Teknologi baru harus diperkenalkan ke dalam proses belajar mengajar yang dilakukan peserta didik untuk siap dalam menghadapi tantangan dunia di era Revolusi industri 4.0 (Priskawati, 2020).

Pada era pandemi Covid-19 kondisi zaman yang sedang terjadi menyadari bahwa dunia pendidikan pada dasarnya adalah tempat atau wadah untuk belajar kapan saja, dimana saja, tidak hanya kampus (gedung). Selain itu, situasi ini juga memastikan bahwa instruktur bukan satu-satunya sumber belajar, tetapi siswa memiliki akses ke sumber lain yang sesuai. Selain itu, cara berpikir tentang pembelajaran dari teacher center learning telah berubah menjadi student center learning. Dalam hal ini, pilihan pembelajaran sangat berbeda (Marbun, 2020).

\section{Daftar Pustaka}

Afghani, D. R. (2020). Kreativitas Pembelajaran Daring untuk Pelajar Sekolah Menengah dalam Pandemi Covid-19. Journal of Informatics and Vocation Education (JOIVE), $3(2)$, 70-75. https://doi.org/https://dx.doi.org/10.20961/joive.v3i2 .43057

Dimhari, D. (2021). Blended Learning Alternatif Pembelajaran Pada Pendidikan Tinggi Era New Normal melalui pembelajaran daring ( Yudiawan, Hana Sakura Putu 
Arga, Jajang Bayu Covid-19 Pertimbangan pemilihan Pendidikan Geografi antara lain satu-satunya program studi di Unive. Georafflesia, 6(1).

Fatimah, S. (2019). Pembelajaran di Era New Normal.

Handarini, O., Ika, K., \& Wulandari, S. S. (2020). Pembelajaran

Daring Sebagai Upaya Study From Home ( SFH ) Selama

Pandemi Covid 19 Pembelajaran Daring Sebagai Upaya Study From Home ( SFH ) ..... Jurnal Pendidikan Administrasi Perkantoran (JPAP), 8(3), 496-503.

Hikmah, A. N., \& Chudzaifah, I. (2020). Blanded Learning: Solusi Model Pembelajaran Pasca. Al-Fikri: Jurnal Pendidikan Islam, 6(2), 83-94.

Marbun, P. (2020). Disain Pembelajaran Online Pada Era Dan Pasca Covid-19. Purim Marbun, 12(1), 129-142.

Ni'matul Khoiroh, D. (2017). Pengaruh Model Pembelajaran Blended Learning dan Motivasi Belajar terhadap Hasil Belajar Siswa. Penelitian Ilmu Pendidikan, 10(2), 97110.

Nurhadi, N. (2020). Blended Learning Dan Aplikasinya Di Era New Normal Pandemi Covid-19 Blended Learning And Its Application In The New Normal Era Of The Covid-19 Pandemic. Agrieskstensia, 19(2).

Priskawati, J. dan dewi. (2020). Blended Learning: Solusi

Pembelajaran New Normal Untuk Pendidikan Agama Kristen. Pendidikan Didaxel, 1(2).

Rohana, S. (2020). MODEL PEMBELAJARAN DARING PASCA PANDEMI COVID 19. At-Ta'dib: Jurnal Ilmiah Prodi Pendidikan Agama Islam, 12(02).

Rohana, S., \& Syahputra, A. (2021). MODEL PEMBELAJARAN BLENDED LEARNING PASCA NEW NORMAL COVID-19. Sy. Rohani Dan Andi Syahputra, 13(1), 48-59.

Sri Agung Pranoto, Adam Wahida, E. K. (2021). PERANAN MANAJEMEN PENGELOLAAN PENDIDIKAN NON 
FORMAL UNTUK MEMPERTAHANKAN EKSISTENSI PADA PANDEMI COVID-19. Prosiding Seminar Nasional Desain Dan Arsitektur (SENADA), 4, 374-379.

Wardani, D. N. W. dkk. (2018). DAYA TARIK PEMBELAJARAN DI ERA 21 DENGAN BLENDED LEARNING Deklara Nanindya Wardani, Anselmus J.E. Toenlioe, Agus Wedi. Deklara Nanindya Wardani, Anselmus J.E. Toenlioe, Agus Wedi, 1(1), 13-18. 


\title{
PEMBELAJARAN MATEMATIKA BERORIENTASI BUDAYA: ALTERNATIF PEMBELAJARAN PASCA PANDEMI COVID-19
}

\author{
Dr. Wara Sabon Dominikus, M.Sc. ${ }^{14}$ \\ (Universitas Nusa Cendana Kupang)

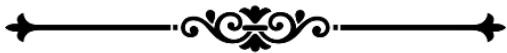

"Pembelajaran matematika berbasis budaya (etnomtematika) membuat pembelajaran matematika menjadi lebih menarik dan sekaligus sebagai upaya pelestarian budaya secara sistematis melalui pembelajaran matematika"

\section{Budaya dan Pendidikan}

Dewasa ini Ilmu Pengetahuan dan Teknologi (IPTEK) berkembang sangat pesat. Iptek berkontribusi besar dalam pengembangan teknologi pendidikan. Teknologi pendidikan pun semakin berkembang seiring dengan tuntutan perkembangan zaman khususnya tuntutan terhadap dunia pendidikan. Di sisi lain nampak semakin meningkat laju perkembangan inovasi di bidang pendidikan. Inovasi di bidang pendidikan yang didukung oleh teknologi pendidikan akhirnya mendisrupsi dunia pendidikan sehingga memaksa dunia pendidikan untuk mengadaptasi diri dalam berbagai aspek agar tidak ketinggalan atau ditinggalkan. Disrupsi pendidikan sangat nyata terutama di masa pandemi Covid-19 dan era new norm saat ini. Pembelajaran yang biasanya

${ }^{14}$ Penulis adalah dosen Pendidikan Matematika di Universitas Nusa Cendana. 
berlangsung di ruang kelas kini terpaksa harus dilakukan di rumah-rumah. Pembelajaran yang bisanya difasilitasi guru dan tatap muka secara langsung dengan para siswa kini harus dilakukan secara virtual menggunakan berbagai platform dan aplikasi teknologi. Para guru pun harus mendisrupsi dirinya menyesuaikan pola pembelajarannya baik dalam jaringan (daring) maupun luar jaringan (luring) baik dengan pola sinkronous maupun asinkronous. Dunia pendidikan pun secara perlahan tapi pasti bergerak maju menuju digitalisasi pendidikan yang pada akhirnya membentuk budaya digital (Sugiharto, 2019).

Seiring dengan perkembangan teknologi pendidikan, kurikulum pendidikan pun dituntut untuk mengintegrasikan budaya dalam pembelajaran di sekolah termasuk pembelajaran matematika. Hal ini dengan tujuan untuk mempersiapkan peserta didik menjadi generasi berkarakter yang mampu menjaga dan melestarikan budaya baik budaya lokal (daerah) maupun budaya nasional (bangsa) juga untuk menanamkan nilai-nilai budaya dan karakater.

Budaya menunjukkan ciri khas suatu suku bangsa. Indonesia memiliki budaya yang sangat beragam yang tersebar dari Sabang sampai Merauke. Dalam konteks ilmu antropologi, kebudayaan didefinisikan sebagai keseluruhan system gagasan, tindakan, dan hasil karya manusia dalam konteks satu kesatuan komunitas manusia dalam satu jejaring luas yaitu kehidupan masyarakat. Para ahli antropologi mendefinisikan kebudayaan sebagai keseluruhan system gagasan, tindakan, dan hasil karya manusia yang harus dibiasakannya dengan belajar, beserta keseluruhan dari hasil budi dan karya manusia seperti seni, hukum, adat istiadat, serta kesanggupan dan kebiasaan manusia lainnya yang dipelajari (Koentjaraningrat, 2009; Bakker, 1984; Keesing, 1981). Selanjutnya ada terdapat 7 unsur kebudayaan yang dapat ditemukan dalam semua kebudayaan dunia antara lain: 1) system religi, kepercayaan dan upacara keagamaan, termasuk iman dan komitmen; 2) system dan organisasi 
kemasyarakatan seperti struktur sosial dan gender; 3) system pengetahuan: temuan, habitus, tradisi, warisan, temuan baru; 4) bahasa, langgam dan bentuk bicara; 5) Kesenian, berbagai macam ungkapan rasa seni; 6) System mata pencaharian hidup' 7) system teknologi: media dan teknologi (Koentjaraningrat, 2009; Neonbasu, 2020).

\section{Pembelajaran Berorientasi Budaya}

Pola pembelajaran berorientasi budaya dapat dibedakan menjadi tiga macam (Goldberg, 2000) yaitu: 1) Belajar tentang budaya. Dalam hal ini budaya ditempatkan sebagai bidang ilmu. Budaya dipelajari dalam satu matapelajaran khusus dan tidak diintegrasikan dengan mata pelajaran yang lain. Artinya ada matapelajaran yang dikhususkan untuk belajar tentang budaya. Perkembangan matapelajaran tentang budaya sangat tergantung dari sumber belajar yang dimiliki sekolah. Sekolah yang sumber daya belajarnya memadai maka matapelajaran tentang budaya akan berkembang lebih baik. Sebaliknya jika sumber daya sekolah kurang memadai maka matapelajaran budaya ini pastinya kurang berkembang, dan pada akhirnya siswa hanya menghafal saja dari sumber buku atau cerita guru tentang budaya. Sumber belajar tentang budaya yang harus disiapkan dan dimanfaatkan antara lain: buku, nara sumber budaya, lingkungan budaya, alat-alat dan perlengkapan, cerita, alat music, artefak budaya dan lainnya. Fakta menunjukkan bahwa matapelajaran budaya dan pengetahuan tentang budaya tidak mendapat tempat yang proposional baik dalam kurikulum maupun dalam pengembangan pengetahuan secara umum bila dibandingkan dengan mata pelajaran lainnya. 2) Belajar dengan budaya. Belajar dengan budaya terjadi pada saat budaya digunakan sebagai cara atau metode untuk mempelajari matematika atau mata pelajaran lain. Dalam hal ini budaya dan bentuk atau wujud budaya lainnya dijadikan sebagai media pembelajaran dalam proses belajar, konteks dari contoh tentang konsep atau prinsip dalam mata pelajaran matematika, serta konteks penerapan prinsip atau prosedur 
dalam mata pelajaran matematika. Misalnya dalam membelajarkan konsep perkalian 4 sebagai penjumlahan berulang, digunakan kolen (satuan mengikat jagung) dan mata' (satuan banyak buah kemiri dalam permainan kenoli) dalam budaya Lamaholot di bagian Timur pulau Flores, pulau Adonara, pulau Solor, pulau Lembata, dan pulau Pantar. Kolen adalah satuan hitung yang merujuk pada satu ikatan jagung yang terdiri dari 4 bulir jagung. Sedangkan mata' adalah satuan hitung yang merujuk pada kumpulan yang terdiri dari 4 buah kemiri. 3) Belajar melalui budaya. Belajar melalui budaya merupakan metode yang memberikan kesempatan kepada siswa untuk menunjukkan pencapaian pemahaman atau makna yang diciptakannya dalam pelajaran matematika melalui ragam perwujudan budaya. Belajar melalui budaya merupakan salah satu bentuk multiple representation of learning assesment atau bentuk penilaian pemahaman dalam beragam bentuk. Misalnya, siswa tidak perlu mengerjakan tes tentang bangun datar tetapi siswa dapat membuat poster, membuat lukisan, lagu, ataupun puisi tentang bangun datar. Belajar melalui budaya memungkinkan siswa untuk memperlihatkan kedalaman pemikirannya terhadap konsep atau prinsip matematika yang dipelajari, serta imaginasi kreatifnya untuk mengekspresikan pemahamannya. Belajar melalui budaya dapat dilakukan di semua jenjang pendidikan dari sekolah dasar, sekolah menengah, hingga perguruan tinggi dalam mata pelajaran atau mata kuliah matematika dan matapelajaran lainnya.

\section{Pembelajaran Matematika Berorientasi Budaya}

Berbagai usaha dilakukan pemerintah Indonesia untuk mempertahankan dan melestarikan budaya bangsa dan budaya lokal. Salah satu upaya yang dilakukan pemerintah adalah melalui pelaksanaan pendidikan karakter dan budaya bangsa bagi para siswa di sekolah. Pendidikan matematika dan pembelajaran matematika turut berperan dalam upaya pelestarian budaya dan penanaman nilai-nilai budaya. Hal ini didasarkan pada kenyataan bahwa matematika merupakan 
konstruksi sosial-budaya, fenomena budaya, aktivitas budaya, produk budaya, terkandung dalam budaya, tersembunyi dalam budaya, memengaruhi budaya, dan membentuk budaya (Ernest, 1993; Bishop, 1988; Gerdes, 1997, 2011; Dowling, 1998; Dominikus, 2014, 2015, 2016,2017,2018,2019).

Hasil kajian matematika dalam budaya yang kemudian diintegrasikan dalam pembelajaran matematika merupakan strategi dan upaya pendidikan (pendidikan matematika) dalam pelestarian dan pewarisan budaya. Dengan demikian matematika sesungguhnya memiliki kekuatan yang dapat digunakan untuk mempertahankan budaya dan memajukan budaya karena matematika itu sendiri terkandung dalam budaya dan menyatu dengan budaya. Bahwa dalam budaya ada matematika yang umunya dikenal dengan Etnomatematika (matematika budaya). Hal ini menginidiaksikan bahwa pada setiap aktivitas budaya terdapat etnomatematika. Dalam setiap suku atau etnis ada etnomatematika yang khas, maka yang patut dilakukan di sekolah adalah bagaimana membelajarkan matematika menggunakan konteks budaya (Dominikus, 2019).

Pembelajaran matematika berbasis budaya (etnomatematika) juga merupakan salah satu tuntutan kurikulum 2013 yang sedang diterapkan di setiap sekolah saat ini (Fajriyah, 2018). Di mana pembelajaran yang berbasis etnomatematika memfasilitasi pengonstruksian konsep matematika oleh siswa sendiri bermodalkan pengetahuan tentang budaya yang mereka miliki. Selain itu integrasi budaya (etnomatematika) dalam pembelajaran matematika membuat materi ajar menjadi lebih bermakna karena bersentuhan langsung dengan aspek kehidupan sehari-hari siswa. Selain itu, pembelajaran berbasis budaya ini mampu menumbuhkan rasa cinta peserta didik pada budaya-budaya lokal sebagai bagian dari perwujudan rasa nasionalisme.

Dengan pembelajaran matematika berbasis etnomatematika, maka secara simultan siswa lebih memahani dan mengenal budayanya dan sekaligus lebih mudah 
meahami matematika. Semakin siswa mengenal budayanya maka semakin mereka menyenangi dan mencintai budayanya. Dengan pengintegrasian budaya dalam belajar matematika di sekolah maka di satu sisi membantu upaya pelestarian budaya dan di sisi lain para siswa akan berkembang dan bertumbuh di atas budayanya.

\section{Tahapan Pembelajaran Berbasis Etnomatematika}

1. Tahap Eksplorasi (Exploration): Pada tahap ini siswa menggali ide matematis dalam budaya. Siswa diberikan materi tentang budaya (literasi budaya). Pada tahapan ini siswa mengenal dan tahu serta mengingat kembali budaya yang menjadi konteks pembelajaran. Memanfaatkan sumberdaya yang bervariasi dalam pembelajaran matematika. Sumber belajar tidak hanya guru dan buku. Diperoleh berbagai ide matematis atau praktik matematika dalam budaya yang disebut sebagai etnomatematika.

2. Tahap Pemetaan (Mapping): Pada tahap ini guru mendampingi siswa membuat peta hubungan antara konsep matematika sekolah dan etnomatematika. Identifikasi konsep matematika yang terkait dengan etnomatematika. Selanjutnya siswa memilih konsep matematika yang bersesuaian untuk dipelajari baik secara individu maupun kelompok.

3. Tahap Eksplanasi (Explanation): Siswa mempelajari konsep matematika sekolah secara individu atau kelompok, mengkomunikasikan apa yang dipelajari, saling berbagi, mengapresiasi apa yang dipelajari dalam berbagai bentuk.

4. Tahap Refleksi (Reflextion): merangkum apa yang dipelajari baik pengetahuan matematika dan nilai-nilai hidup (living values) yang dikembangkan dan diperoleh dalam proses pembelajaran matematika. 


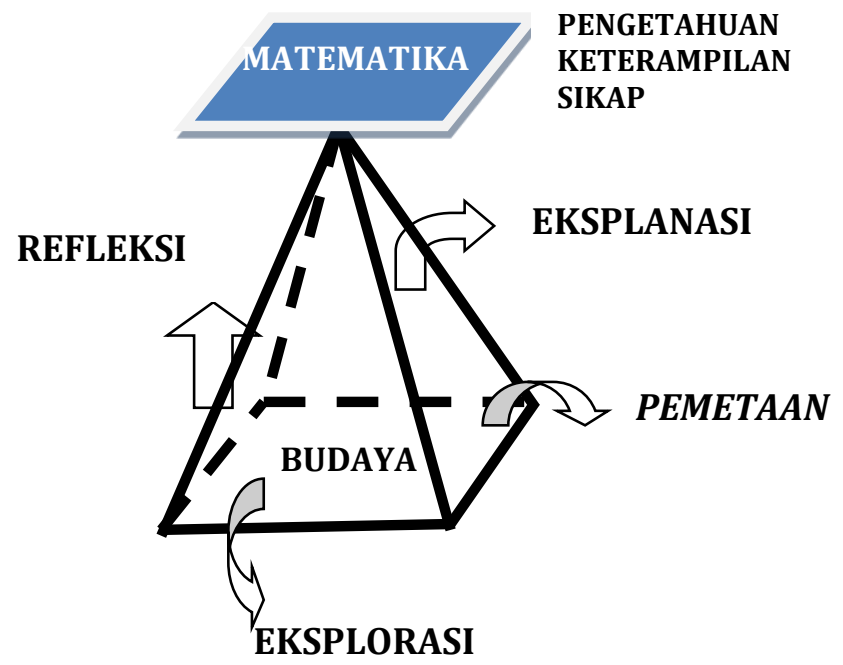

Gambar 1. Piramida Pembelajaran Berbasis Etnomatematika

\section{Dampak Pembelajaran Matematika Berbasis} Etnomatematika:

Ada beberapa dampak dari penerapan pembelajaran berbasis Etnomatematika antara lain: (1) Pembelajaran matematika menjadi pembelajaran yang menyenangkan dan kontekstual; (2) Dapat mereduksi kesan bahwa matematika itu sulit dan abstrak dan tergantikan dengan kesan bahwa matematika itu menyenangkan dan nyata ada dalam setiap aktivitas kehidupan; (3) Mengenal budaya sendiri dan budaya lain; (4) Kesadaran menghargai dan mencintai budaya sendiri dan budaya lain; (5) Bagian dari upaya pelestarian budaya secara sistematis melalui pendidikan matematika pada khususnya dan pendidikan pada umumnya. Hadirnya etnomatematika dalam proses pembelajaran matematika membawa pemahaman baru bahwa belajar matematika tidak selamanya di dalam kelas saja, tetapi bisa juga di luar sekolah, 
di lingkungan sosial budaya setempat. Dalam hal ini budaya setempat dapat digunakan sebagai sumber belajar, media pembelajaran, dan konteks pembelajaran matematika.

\section{Daftar Pustaka}

Bakker,J.W.M., (1984), Filsafat Kebudayaan sebuah Pengantar, Penerbit PT. Kanisius, Yogyakarta

Bishop, A.J., (1988), The Interaction of Mathematics Education with Culture, Culture Dynamics 1988:1; pp. 145-157. DOI: $10.1177 / 92137408800100200$

Dominikus, W.S., Nusantara, T., Subanji, \& Muksar, M., (2014a), Ethnomathematics in Shifting Cultivation of Adonara Societty and Integration Within Curriculum of Primary Schools, Proceedings: The $1^{\text {st }}$ Sriwijaya University Learning and Education International Conference (SULE-IC) 2014, Sriwijaya University, May 16-18, 2014, Palembang, pp. D16-786 - D16-793.

Dominikus, W.S., Nusantara, T., Subanji, \& Muksar, M., (2014b), Etnomatematika Dalam Permainan Masyarakat Adonara dan Kaitannya Dengan Matematika Sekolah Dasar, Prosiding Seminar Nasional Matematika dan Pendidikan Matematika, Universitas Sanata Dharma Yogyakarta, 13 September 2014, Yogyakarta, pp. 531-542

Dominikus, W.S., Nusantara, T., Subanji, \& Muksar, M., (2015), Ethnomathematics of Adonara Society in The Weaving Activity, Paper presented on International Conference of Mathematics and Scince Education (ICMSE), Mataram University, November 4-6, 2015, Mataram, pp. 1-10.

Dominikus, W.S., Nusantara, T., Subanji, \& Muksar, M., (2016a), Ethnomathematics in Marriage Tardition in Adonara Island-East Flores, Proceedings: $3^{\text {rd }}$ International Conference on research Implementation, 
and Education of Mathematics and Science 2016 ( $3^{\text {rd }}$ ICRIEMS), Yogyakarta State University, May 16-17, 2016 Yogyakarta, pp. ME-269 - ME-274.

Dominikus, W.S., Nusantara, T., Subanji, \& Muksar, M., (2016b), Link Between Ethnomathematics in Marriage Tradition in Adonara Island and School Mathematics, IOSR Journal of Research \& Method in Education (IOSR$J R M E$ ), Volume 6, Issue 3 Ver. IV (May-June 2016), pp. 56-62, DOI:10.9790/7388-0603045662

Dominikus, W.S., (2016c), Etnomatematika Adonara dan Kaitannya Dengan Matematika Sekolah, Disertasi Universitas Negeri Malang, Malang

Dominikus, W.S., Nusantara, T., Subanji, \& Muksar, M., (2017), Ethnomathematical Ideas in the Weaving Practice of Adonara Society in Indonesia, Journal of Mathematics and Culture, December- 11(4). pp. 83-95,

Dominikus, W.S., (2018a), Literasi Matematika Dalam Budaya Lamaholot, Makalah disampaikan dalam Seminar: Aku Dalam Pusaran Budaya Lamaholot, Seminar HUT Ikatan Keluarga Adonara (IKA) Lembata, di Lewoleba, $14 \mathrm{Mei}$ 2018

Dominikus, W.S., (2018b), Literasi Matematika Budaya Menuju Pembelajaran Berbasis Budaya, Orasi Ilmiah pada Wisuda Perdana STKIP Nusa Floresta, di Mbay. 1 September 2018

Dominikus, W.S, (2018c), Etnomatematika Adonara, Media Nusa Cretive, Malang

Dominikus, W.S, (2019), Etnomatematika Flobamorata, Makalah disampaikan dalam Kuliah Umum Program Studi Pendidikan Matematika FKIP Undana, Kupang, 28 Februari 2019

Dominikus, W.S, (2019), Pembelajaran Matematika Berbasis Etnomatematika (PMBE), Prosiding Seminar Nasional Pendidikan Matematika, Program Studi Pendidikan 
Matematika Fakultas Keguruan Dan Ilmu Pendidikan Universitas Nusa Cendana, pp. 8-13

Dowling, P., (1998), The Sociology of Mathematics Education,

Studies in Mathematics Education Series 7, The Falmer

Press, London

Ernest,P., 1993, The Philosophy of Mathematics Education, The Falmer Press, London

Fajriyah, E. (2018). Peran Etnomatematika Terkait Konsep Matematika dalam Mendukung Literasi, Prisma, Prosiding Seminar Nasional Matematika, Pp. 114 - 119, https://journal.unnes.ac.id/sju/index.php/prisma/

Gerdes,P., (1997), Survey of Current Work on Ethnomathematics, In A. Powell \& M. Frankenstein (eds), Ethnomathematics, Challenging Eurocentrism in Mathematics Education (pp. 331-372), Albany: State University of New York Press.

Goldberg, M. (2000). Art and learning: An integrated approach to teaching and learning in multicultural and multilingual settings. nd 2 Ed. New York: Addison Wesley Longman

Keesing, R.M., (1981), Cultural Anthropology:A Contemporary Perspective, Edisi 2 terjemahan S. Gunawan , Antropologi Budaya: Suatu Perspektif Kontemporer, Erlangga, Jakarta

Kuntjaraningrat, (2009), Pengantar Antropologi I, Rineka Cipta, Jakarta

Neonbasu, G, (2020), Sketsa Dasar Mengenal Manusia dan Masyarakat, Penerbit Buku Kompas, Jakarta

Sugiharto, B, (2019), Kebudayaan dan Kondisi Post-Tradisi, Penerbit PT. Kanisius, Yogyakarta 


\title{
MEMBUMIKAN EKSISTENSI NILAI PENDIDIKAN MULTIKULTURAL PASCA PANDEMI COVID-19 DI LINGKUNGAN PONDOK PESANTREN
}

\author{
Abdul Khamid, M.Pd. ${ }^{15}$ \\ (Institut Agama Islam Negeri Salatiga, Indonesia)

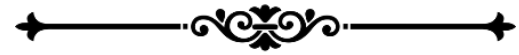

"Penanaman nilai pendidikan multikultural dilingkungan

Pondok Pesantren pasca pandemi Covid-19 dilaksanakan dengan baik dengan melakukan berbagai pendekatan kepada seluruh santri dengan berbagai pengarahan, motivasi serta kerjasama kepada pengelola Pondok Pesantren dengan orangtua wali santri"

\begin{abstract}
Cerangan adanya wabah pandemi covid-19 meluluh Slantakkan di berbagai sistem kehidupan yang banyak di alami semua Negara, semua merasakan akan dampak yang luar biasa dimulai dari kesehatan, ekonomi, sampai politik semuanya dipaksa untuk tiarap sementara waktu guna mencegah akan penularan virus mematikan. Fenomena yang tidak biasa ini membuat semua manusia ketakutan dengan berbagai penanganan aksi preventif dengan penuh kehatihatian dalam melaksanakan kegiatan yang menimbulkan
\end{abstract}

\footnotetext{
${ }^{15}$ Penulis lahir di tanah kelahiran yang berada di Kabupaten Grobogan. Penulis merupakan Dosen aktif di IAIN Salatiga. Penulis menyelesaikan Pendidikan sarjana Pendidikan Agama Islam IAIN Salatiga (2017). Kemudian melanjutkan ke jenjang Magister Pendidikan Agama Islam IAIN Salatiga (2019). Di Tahun (2021) ini penulis melanjutkan Studi Pascasarjana Program Doktor dengan kosentrasi Pendidikan Agama Islam.
} 
banyak kerumunan. (Hosaini, 2020) Dalam keadaan yang serba sulit saat ini menjadikan Negara Indonesia salah satunya dalam menjaga kenyamanan masyarakat tidak hanya sekedar membahas wabah pandemi covid-19 saja, melaikan juga membuat banyaknya perbedaan-perbedaan yang bermunculan di kalangan orang banyak yang menyangkut masalah agama. Hal ini dapat dilihat selama adanya wabah pandemi didapati perbedaan-perbedaan dalam melaksnakan ibadah.

Seruan-seruan pemerintah, kesehatan bahkan tokoh agama ikut serta dalam mensosialisasikan akan bahaya wabah ini, sehingga masyarakat luaspun dipaksa untuk tidak melaksanakan kegiatan di luar yang menyebabkan kerumunan sehingga memudahkan penularan wabah virus covid-19, dunia pendidikan dipaksa melaksnakan pembelajaran secara virtual. Dengan berbagai ihktiyar atau usaha ini Negara Kesatuan Republik Indonesia saat ini mulai memasuki level aman, sehingga mulai ada pemberlakuan pendidikan sebagian sudah melaksanakan PTMT (Pembelajaran Tatap Muka Terbatas Pasca Pandemi), semua itu dilakukan pelan-pelan dengan tetap menggunakan prokes yang ketat, hal tersebut juga mulai banyak di terapkan dalam dunia Pondok Pesantren yang sudah mulai melaksanakan pembelajaran tatap muka.

Berbicara kaitan dunia pesantren merupakan sebuah lembaga pendidikan keagamaan yang berperan aktif di dalam ikut serta pengembangan masyarakat terutama pada masyarakat desa, sejak awal fungsi pondok pesantren merupakan tempat penyelenggaraan pendidikan terutama lebih dititik beratkan pada belajar mengajar ilmu-ilmu keagamaan. (Setyorini, 2003). Membicarakan isu-isu yang berkembang saat ini kaitan agama mengalami sebuah dinamika yang cukup keras dengan adanya sebuah kasus radikalisme yang menjadikan keprihatinan kita bersama sebagai umat manusia. (Rahmat, 2014). Menanamkan serta membentuk sikap multikultural di dalam tubuh manusia atau 
para santri merupakan suatu hal yang penting untuk dilakukan. Sehingga para santri atau peserta didik mempunyai sikap keberagaman serta mau menerima sebuah perbedaan yang ada, menghargai serta menghormati dalam kehidupan sehari-hari dilingkungan pondok pesantren.

Menengok kebelakang perjalanan panjang lembaga pondok pesantren berbagai priode di bumi Indonesia, pondok pesantren tumbuh serta terus berkembang, sehingga pondok pesantren mempunyai peranan penting, pondok pesantren mempunyai tiga peranan fungsi pertama, sebagai pusat kaderisasi pemikiran agama Islam. Kedua, sebagai lembaga yang ikut serta mencetak sumber daya manusia. Ketiga, sebagai institusi mempunyai banyak kekuatan untum memperkuat masyarakat. (Faozan, 2006).

Memasuki new normal ini diperlukannya penyemangat dalam dunia lembaga pondok pesantren untuk kembali menggelorakan pendidikan multikultural kepada para santri menerima akan perbedaan sehingga menjadi insan manusia yang moderat. Pendidikan multikultural tersebut bisa dilihat dalam setiap displin keilmuan Islam, baik dari aspek tasawuf, syariah, akidah, tafsir, hadis, dan lain sebagainya. Pengajaran penanaman-penanaman nilai yang terkandung melalui pendekatan jalur pendidikan. Karena pendidikan menjadikan sebuah cerminan di dalam kehidupan.

\section{Nilai Pendidikan Multikultural Di Lingkungan Pondok Pesantren Pasca Pandemi Covid-19}

Negara kesatuan Republik Indonesia merupakan Negara yang majemuk serta plural hal semacam ini bisa kita lihat dari berbagi perbedaan yang ada di Negara kita baik dari segi etnis, budaya, agama, bahasa, pendidikan, ekonomi dan lain sebagainya. Pentingnya dalam sebuah lembaga pendidikan Pondok Pesantren menanamakan nilai dari pendidikan yang berwawasan multikultural, hal tersebut mengapa? Kita pahami bersama karena Allah SWT menciptakan manusia dengan berbagai suku supaya kita semuanya saling mengenal 
serta saling memahami satu dengan lainnya. Peran pendidikan di sini sangatlah setrategis totalitas yang terdiri dari berbagai komponen yang tidak bisa di pisahkan serta mempunyai fungsi dalam rangka mencapai sebuah tujuan.

Pondok Pesantren merupakan sebuah lembaga tertua yang berada di bumi Nusantara yang sudah terbukti bersama dalam menanamakan nilai-nilai multikultural kepada seluruh santri sudah terbilang dari dulu. Dalam suasana Negara Indonesia mengalami wabah pandemi Covid-19 ini diperlukannya kembali membumikan peranan penanaman nilai multikultural. adapaun nilai-nilai yang di ajarkan serta dilaksanakan di lingkungan Pondok Pesantren diantaranya: Pertama, Nilai Toleransi, di Pondok Pesantren seluruh santri di ajarkan serta di anjurkan saling menghargai seluruh perbedaan yang terdapat setiap santri baik dari segi kepribadian, asal daerah, kecerdasan, bahkan status sosial. Kedua, nilai perdamaian, Pondok Pesantren di ajarkannya dalam kehidupan sehari-hari dalam santri untuk memiliki sikap rukun kepada semua santri lainnya. Ketiga, Nilai Keanekaragaman, perbedaan-perbedaan di Pondok Pesantren merupakan suatu hal yang tidak bisa dihindarkan, hal tersebut merupakan di ekspresikan kedalam sebuah kurikulum, materi ajar kitab-kitab klasik atau yang sering di sebut dengan kitab kuning yang di jadikan sebuah referensi dalam pembelajaran sehari-hari. Keempat, nilai persamaan dan keadilan, lembaga pendidikan di Pondok Pesantren mempunyai sebuah tradisi baik dari pengajarnya seperti halnya Kyai maupun ustadnya menanamkan nilai persamaan maupun keadilan, seluruh santri mempunyai hak sama untuk memperoleh pendidikan serta pelayanan yang sama tanpa harus memandang sosial ekonomi. Kelima, nilai kebersamaan dan persaudaraan, Pondok Pesantren lembaga pendidikan yang mengajarkan akan ilmu-ilmu agama yang di ketahui seluruh santrinya berasal dari berbagai penjuru Nusantra, sehingga setidaknya para santri merasa sama-sama bersal dari jauh, seluruh santri menyakini sama-sama orang yang 
beragama Islam, dan seluruh santri memiliki sebuah tujuan yang sama yaitu dalam rangka mencari dan mendalami ilmu agama Islam, sehingga ini menjadikan sebuah pijakan yang perlu ditanamkan bahwasannya di perlukannya kolaborasi berbaur bersama setiap kegiatan seperti halnya saudara sendiri. Keenam, nilai musyawarah, dalam kesehariannya santri di ajarkan akan akan mau menghargai pendapat santri lainnya, dalam ilmu pesantren biasa di sebut dengan sebutan Bashtsul masail hal demikian tidaklah asing bagi santri di Pondok Pesantren mengadakan sebuah musyawarah bersama untuk mengkaji kitab-kitab klasik untuk membahas isu-isu persoalan keagamaan. Tidaklah jarang dalam musyawarh tersebut terjadi perdepatan yang panjang, namun di akhir setelah diberikannya sebuah penjelasan, seluruh santri menerima dengan penuh kebahagiaan dengan adanya sistem musyawarah bersama.

Pendidikan di Pondok Pesantren secara internal sudah banyak memperaktikkan Pendidikan Agama Islam berbasis multikultural, baik secara aplikatif maupun melalui doktrindoktrin serta ajaran kitab kuning yang dijadikan sebuah referensi, motode pembelajaran, perbedaan-perbedaan Mahdzab maupu pengamalan dalam hidup sehari-hari di lingkungan Pondok Pesantren. (Aly, 2016).

Sehingga dalam penanaman nilai pendidikan multikultural dilingkungan Pondok Pesantren pasca pandemi Covid-19 tetap dilaksanakan dengan baik dengan melakukan berbagai pendekatan kepada seluruh santri dengan berbagai pengarahan, motivasi seta kerjasama yang apik kepada pengelola Pondok Pesantren dengan orangtua wali santri dalam ikut serta mengokohkan penanaman nilai-nilai multikultural. 


\section{Daftar Pustaka}

Aly, Abdullah. 2016. Pengembangan Pembelajaran Karakter Berbasis Soft Skills. Ishraqi.

A, Faozan, "Pondok Pesantren dan Pemberdayaan Ikonomi", Jurnal Ibda': Jurnal Studi Islam dan Budaya,Vol. 4, No. 1, 2006.

Hosaini. 2020 "Pembelajaran dalam Era New Normal di Pondok Pesantren Nurul Qurain Jember tahun 2020". Jurnal: Lisan Al-Hal. Vol. 14 No. 2 Tahun 2020

Rahmat Suprapto, "Deradikalisasi Agama melalui Pendidikan Multikultural". Jurnal: Profetika. Jurnal Studi Islam. Vol. 15 No. 2 Tahun. 2014.

Setyorini. 2003. Manajemen Pendidikan Islam. Yogyakarta: Teras. 


\title{
MANAJEMEN KELAS PADA MASA PANDEMI
}

\author{
Nurmalina, M.Pd. ${ }^{16}$
}

(IAIN Takengon)

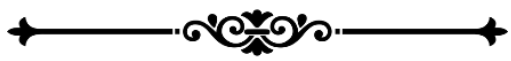

"Manajemen kelas berhasil apabila terciptanya lingkungan belajar yang tertib, kondusif, disiplin dan semangat dalam belajar, adanya jalinan yang baik antara siswa dengan guru ataupun sebaliknya"

Dandemi melanda dunia dan juga bangsa Indonesia sejak
tahun 2019 dengan merambahnya corona virus covid-19. Corona virus covid-19 membuat semua bidang perekonomian dan pendidikan mengalami keterpurukan pada awalnya. Hal tersebut karena virus tersebut ada pada diri manusia, jadi apabila satu manusia sudah terkena virus tersebut, maka yang lainnya tidak boleh mendekatinya sehingga setiap manusia harus menjaga jarak dengan manusia lainnya. Semua bangsa dan negara berusaha untuk melawan virus covid-19 dengan berbagai cara, diantaranya dengan membuat kebijakankebijakan berupa karantina daerah (lockdown), PSBB (pembatasan sosial berskala besar) baik di tingkat provinsi maupun kabupaten atau kota. Dalam keadaan tersebut tempat-tempat keramaian di tutup, begitu juga dengan

16 Penulis lahir di Aceh Besar dan sekarang menjadi Dosen Tetap di IAIN Takengon Aceh Tengah dalam bidang ilmu Manajemen Pendidikan Islam, penulis menyelesaikan gelar Sarjana di Institut Agama Islam Negeri Ar Raniry Banda Aceh, sedangkan gelar Magister Pendidikan diselesaikan di Universitas Syiah Kuala Banda Aceh Program Studi Administrasi Pendidikan (2013). 
tempat ibadah dan sekolah. Sekolah harus melakukan proses pembelajaran secara jarak jauh yaitu pembelajaran dalam jaringan (daring) dengan memanfaatkan jaringan internet. Semua kegiatan dilakukan dari rumah masing-masing. Sebagaimana yang dikatakan oleh Siahaan (2019:73) "semua kegiatan dilakukan dari rumah baik itu proses pembelajaran maupun yang pekerjaan untuk kantor, supaya corona virus covid-19 dapat dicegah penyebarannya."

Dalam pembelajaran daring tersebut semua pihak yang berpartisipasi dalam bidang pendidikan harus beradaptasi dengan pembelajaran via online. Bahkan peserta didik dan orang tua/wali peserta didik pun ikut andil menyukseskan pembelajaran daring (dalam jaringan) ini. Namun untuk saat ini sudah ada kebijakan pemerintah untuk dapat melakukan pembelajaran tatap muka terbatas, artinya proses pembelajaran dilakukan via online dan juga tatap muka. Untuk itu pihak sekolah khususnya pendidik harus mempersiapkan diri untuk dapat melakukan proses pembelajaran dalam jaringan dan tatap muka, agar pembelajaran yang disampaikan dapat diterima dengan baik oleh peserta didiknya. Hal ini juga harus di dukung oleh pihak sekolah dan orang tua/wali peserta didik, agar tujuan dari pembelajaran dapat tercapai dengan maksimal.

Seorang pendidik harus bisa mengatur kelasnya secara virtual dan tatap muka. Ini diperlukan manajemen yang bagus, karena pembelajaran daring dan tatap muka harus bersinergi.

Manajemen kelas merupakan pengelolaan atau penataan ruang kelas menjadi menarik dan kondusif sehingga proses pembelajaran berjalan efektif, efisien dan dapat memotivasi siswa dalam belajar. Mulyasa (2015: 6) menerangkan bahwa manajemen kelas merupakan kecakapan guru dalam menciptakan suasana pembelajaran yang kondusif, dan mengendalikannya apabila terjadi kendala pada pembelajaran. Menurut Mudasir (2016:8) Manajemen kelas meliputi: 
1. Penataan tempat duduk peserta didik

2. Penataan media pembelajaran (alat peraga) yang terdapat di ruang kelas

3. Penataan kedisplinan peserta didik

4. Penataan interaksi antar peserta didik

5. Penataan pekerjaan peserta didik

6. Penataan ruang kelas

7. Penataan keindahan dan kebersihan kelas

8. Penataan perlengkapan kelas

9. Penataan dekorasi kelas

Penataan kelas sangat perlu dilakukan oleh guru untuk membuat suasana kelas menyenangkan dan menjadikan siswa lebih termotivasi dalam belajar, sehingga berdampak pada hasil belajar yang lebih optimal. Kemudian Karwati dan Priansa (2019:24) juga menyatakan bahwa kegiatan dalam manajemen kelas meliputi:

1. Pengaturan peserta didik (kondisi emosional)
a. Tingkah laku
b. Kedisiplinan
c. Minat/perhatian
d. Gairah belajar
e. Dinamika kelompok

2. Pengaturan fasilitas (kondisi fisik)
a. Ventilasi
b. Pencahayaan
c. Kenyamanan
d. Letak duduk
e. Penempatan peserta didik 
Manajemen kelas yaitu mengelola peserta didik yang ada dalam kelas dan juga mengelola ruang kelasnya. Jadi guru harus mempunyai keterampilan dalam mengelola kelas, agar peserta didik merasa nyaman dan termotivasi dalam belajar.

Pada masa pandemi sekarang ini pembelajaran dilakukan dengan dua model yaitu pembelajaran secara daring dan pembelajaran secara tatap muka terbatas. Kedua model pembelajaran yang dilakukan ini memerlukan pengelolaan kelas, karena itu guru harus mempunyai keahlian dalam hal pengelolaan. C, M (2021: 1600) menjelaskan bahwa pada pembelajaran daring, orang tua mempunyai peran yang penting dan ikut mengawasi dan membimbing anaknya dalam belajar. Guru menerapkan disiplin pada saat pembelajaran berlangsung berupa disiplin pada saat mengikuti aturan serta prosedur kelas online. Mulyasidhi (2021: 144) menyatakan bahwa manajemen kelas dipengaruhi oleh factor guru, peserta didik, orang tua/wali siswa dan fasilitas. Factor-faktor inilah yang menentukan terbentuknya pengelolaan kelas yang efektif. Manajemen kelas berhasil apabila terciptanya lingkungan belajar yang tertib, kondusif, disiplin dan semangat dalam belajar, adanya jalinan yang baik antara siswa dengan guru ataupun sebaliknya. Penyediaan kuota belajar untuk para peserta didik dalam pembelajaran secara online sangat membantu untuk keefektifan belajar.

Untuk pembelajaran secara tatap muka terbatas, guru harus menetapkan protocol kesehatan ketat dalam kelas, baik itu tempat duduknya maupun siswanya. Semuanya harus mengikuti kebijakan protocol kesehatan dari pemerintah, yaitu menjaga jarak, memakai masker dan menjauhi kerimunan. 


\section{Daftar Pustaka}

C, M..., Fimala, Y.., \& Gistituati, N. 2021. Manajemen Kelas Virtual di Sekolah Dasar pada Masa Pandemi. Jurnal Pendidikan Tambusai, 5(1), 1600-1604. Retrieved from https://jptam.org/index.php/jptam/article/view/1145

Evertson, M, Carolyn, dan Edmund T.E. 2011. Manajemen Kelas Untuk Guru Sekolah Dasar. Perpustakaan Nasional: Katalog Dalam Terbitan (KDT

Karwati, E., Priansa, D.J. 2019. Manajemen Kelas Guru Profesional yang Inspiratif, Kreatif, Menyenangkan dan Berprestasi, Bandung: Alfabeta

Siahaan, Matdio. 2019. Dampak Pandemi Covid-19 Terhadap Dunia Pendidikan, Jurnal Kajian Ilmiah (JKI), NO. 1 (7380).

https://doi.org/10.31599/jki.v1i1.265

Mudasir. 2016. Manajemen Kelas. Riau: Zanafa Publishing

Mulyasa,E. 2015. Menjadi Guru Profesional. Bandung: Rosda Karya

Mulyasidhi, G., Haq,M. S. 2021. Manajemen Kelas Dalam Kegiatan Pembelajaran Bagi Siswa Sekolah Dasar Pada Masa Pandemi Covid-19. Jurnal Inspirasi Manajemen Pendidikan, 9(1), 144-155

https://ejournal.unesa.ac.id/index.php/inspirasi-manajemenpendidikan/article/view/38584 


\section{PEMANFAATAN LMS CANVAS INSTRUCTURE UNTUK MENDUKUNG PEMECAHAN MASALAH PADA PEMBELAJARAN MATEMATIKA PASCA PANDEMI}

Julia Noviani, M.Pd. ${ }^{17}$

(IAIN Takengon)

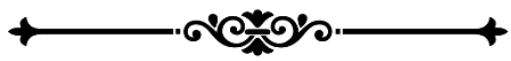

"Canvas membantu guru dan dosen matematika untuk menciptakan lingkungan yang mendukung dengan berbagai

macam strategi pemecahan masalah matematika yang digunakan oleh siswa dan mahasiswa"

Denggunaan LMS (Learning Mangement System) menjadi pembelajaran tatap muka secara terbatas pasca pandemi. Penggunaan LMS tersebut juga merupakan salah satu wujud pembelajaran digital dari perkembangan teknologi di abad ke-21 dan era revolusi industri 4.0. Learning Mangement System (LMS) merupakan aplikasi perangkat lunak yang didesain untuk mendistribusikan, mengatur penyampaian materi pembelajaran serta memudahkan proses pembelajaran. LMS dirancang untuk memfasilitasi multimedia interaktif, bahan ajar, tugas kuliah, diskusi

17 Penulis lahir di Banda Aceh pada tanggal 13 November 1991. Penulis merupakan salah satu Dosen Program Studi Tadris Matematika IAIN Takengon, Aceh Tengah. Penulis menyelesaikan gelar Sarjana Pendidikan Matematika di Universitas Syiah Kuala Banda Aceh (2013), kemudian melanjutkan pendidikannya ke jenjang Magister pada Program Studi Pendidikan Matematika di Universitas Negeri Surabaya di Surabaya (2016). 
online, presentasi, video pembelajaran bahkan video conference yang interaktif (Ellis et al., 2007). Saat ini banyak terdapat LMS yang bersifat open source atau gratis, seperti Canvas, Moodle, Blackboard Coursesites, Google Classroom, Edmodo, Schoology, dan lain-lain.

Salah satu ciri khusus matematika yaitu memiliki bahasa dan simbolnya sendiri yang berbeda dari mata pelajaran lainnya. Pemilihan LMS pada pembelajaran matematika harus mengakomodasi komponen-komponen, simbol dan bahasa matematika (Ahn \& Edwin, 2018). Platform LMS yang dipilih juga harus memiliki fitur yang memungkinkan guru atau dosen untuk mengatur aktivitas dan masalah matematika sedemikian rupa sehingga siswa dan mahasiswa dapat mengikuti prosedur secara sistematis dengan cara yang dinamis dan bersifat interaktif. Salah satu platform LMS yang bersifat open source dan mampu mengakomodasi simbol dan bahasa matematika yaitu LMS Canvas Instructure. Canvas Instructure didirikan pada tahun 2010 dan merupakan platform LMS yang mengalami perkembangan tercepat di dunia, bahkan digunakan oleh $30 \%$ institusi pendidikan tinggi di Amerika Serikat (Instructure, 2019). LMS Canvas Instructure dapat diakses pada laman website https://canvas.instructure.com/ atau https://www.instructure.com/en-au/canvas/try-canvas.

Penggunaan LMS Canvas Instructure membangun kesempatan belajar mandiri mahasiswa pada pembelajaran kombinasi antara tatap muka dan pembelajaran online. Mahasiswa tidak lagi memandang matematika sebagai sesuatu yang hanya dimiliki di dalam kelas, namun juga dapat diakses di luar kelas (Attard \& Holmes, 2020). Kelebihan Canvas Instructure yaitu kemudahan dalam penggunaan, pengorganisasian materi perkuliahan dengan menggunakan berbagai format, jauh lebih fleksibel dibandingkan platform LMS lainnya dan memiliki fitur- 
fitur yang lengkap (Fathema \& Akanda, 2020). Fitur-fitur tersebut adalah sebagai berikut.

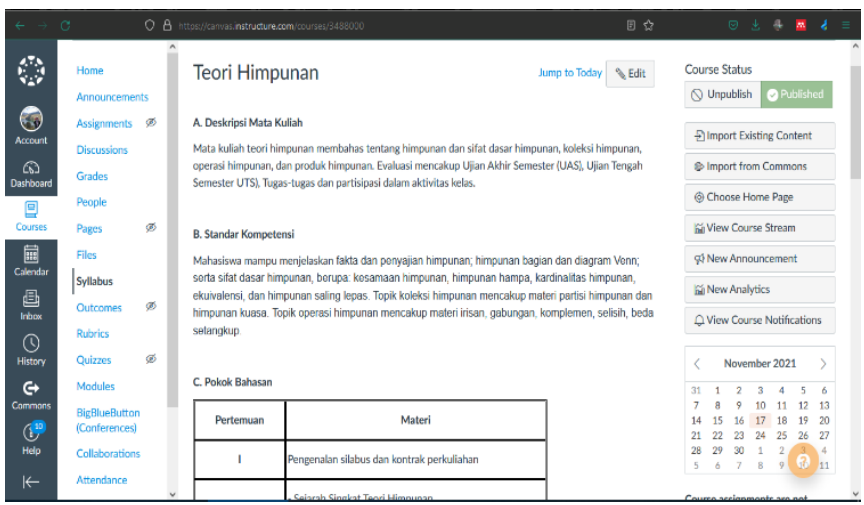

Gambar 1. Fitur-fitur pada LMS Canvas Instructure

Bagaimana LMS Canvas Instructure mendukung pemecahan masalah pada pembelajaran matematika? Pemecahan masalah matematika adalah aktivitas kognitif yang kompleks (Montague et al., 2014). (Zhang et al., 2021) menyatakan bahwa LMS Canvas Instructure mendukung pemecahan masalah matematika yaitu dengan (1) membuat dan mengelola kuis, kartu flash, atau survei pada fitur Quizzes dan HTML Editor, (2) mengintegrasikan platform diskusi video/audio (misalnya Flipgrid) yang memfasilitasi interaksi siswa atau instruksi eksplisit dengan pertanyaan, panduan, dan umpan balik, (3) mengelompokkan siswa dengan menyediakan materi dan/atau kegiatan pemecahan masalah matematika yang disesuaikan dengan kebutuhan siswa secara individu atau kelompok pada fitur Groups, (4) menganalisis data siswa dengan memberikan umpan balik dan memantau perkembangan mandiri siswa pada fitur New Analytics. 


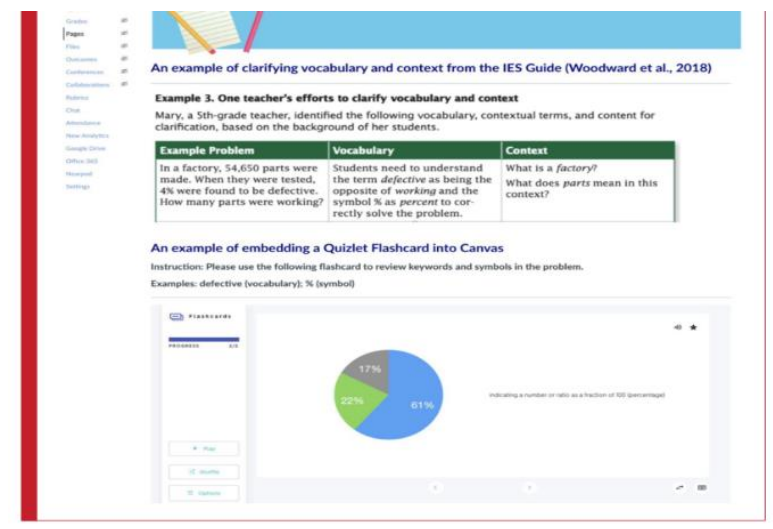

Gambar 2. Webpage pada LMS Canvas Instructure

Pada LMS Canvas, dosen atau guru juga dapat menyematkan gambar, slide Powerpoint, atau situs web yang berupa virtual game manipulatif.

How it looks in Canvas: The webpage is embedded into Canvas. Students can interact with the virtual fraction strips within Canvas without going to another website.

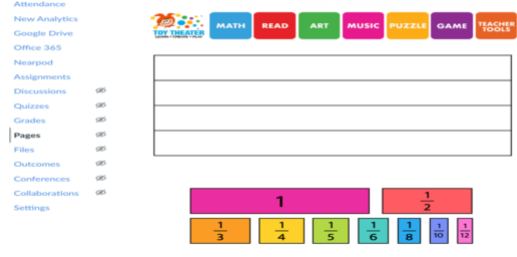

Gambar 3. Webpage pada LMS Canvas Instructure

LMS Canvas Instructure juga mampu mengilustrasikan berbagai cara penyajian strategi/solusi dan membandingkan beberapa strategi pemecahan masalah di Canvas: seperti (a) menyediakan video instruksional tentang berbagai strategi/solusi pemecahan masalah (Gambar 4), (b) menyajikan solusi yang berbeda yang digunakan oleh siswa secara berdampingan pada tampilan 
LMS Canvas (Gambar 5), dan (c) mempresentasikan beberapa solusi secara keseluruhan pada LMS Canvas (Gambar 6). Guru dapat mendemonstrasikan berbagai strategi untuk memecahkan masalah, membandingkan pendekatan yang berbeda, dan menciptakan peluang bagi siswa untuk menggunakan dan menganalisis strategi yang akan digunakan. Mendorong berbagai pendekatan untuk memecahkan masalah berkorelasi dengan akurasi pemecahan masalah yang lebih tinggi bagi siswa (Woodward et al., 2012).

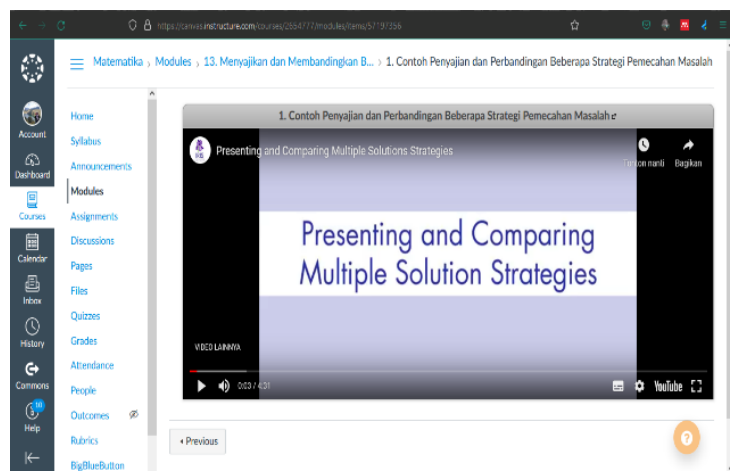

Gambar 4. Video strategi pemecahan masalah

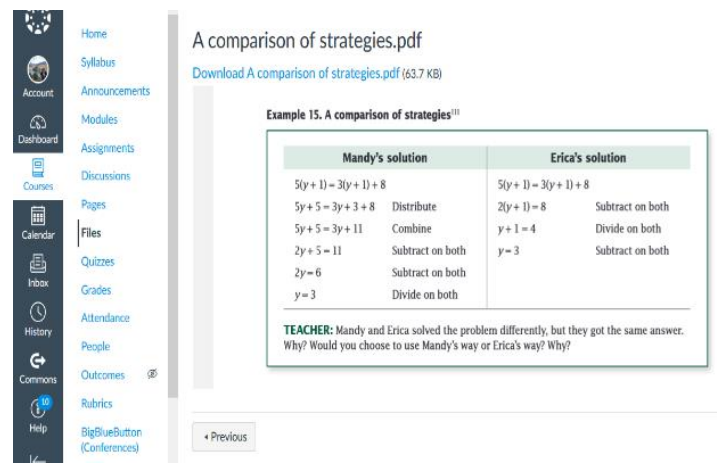

Gambar 5. Perbandingan dua strategi pemecahan masalah 


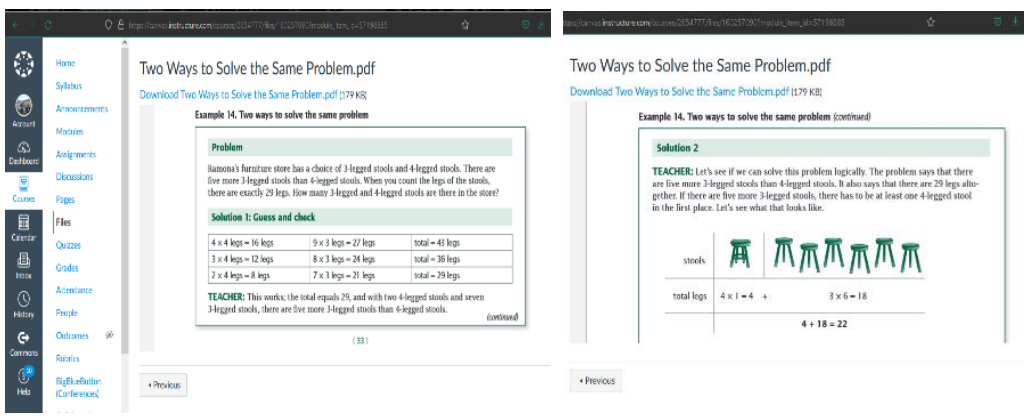

Gambar 6. Beberapa strategi pemecahan masalah

Canvas memberi kesempatan pada siswa untuk berpikir inovatif dalam menggunakan fitur audio atau video, membuat diagram atau grafik, dan melampirkan URL situs web (misalnya Flipgrid) sebagai opsi untuk mengirimkan tugas. Jika siswa memilih untuk menulis simbol matematika, siswa dapat langsung mengetik simbol atau notasi matematika menggunakan Insert Math Equation di Canvas. Canvas membantu guru dan dosen matematika untuk menciptakan lingkungan yang mendukung berbagai macam strategi pemecahan masalah matematika yang digunakan oleh siswa dan mahasiswa. Hal ini membuktikan bahwa penggunaan LMS efektif dalam pembelajaran matematika (Attard \& Holmes, 2020). Seiring dengan upaya bidang pendidikan untuk mengatasi krisis Covid-19 saat ini, pelatihan penggunaan LMS sangat diperlukan untuk mendukung guru dalam menggunakan LMS guna meningkatkan aksesibilitas dan keterlibatan dengan pembelajaran online dan blended learning bagi siswa khususnya pada pembelajaran matematika. 


\section{Daftar Pustaka}

Ahn, J. Y., \& Edwin, A. (2018). An e-learning model for teaching mathematics on an open source learning platform. International Review of Research in Open and Distance Learning, 19(5), 256-267. https://doi.org/10.19173/irrodl.v19i5.3733

Attard, C., \& Holmes, K. (2020). An exploration of teacher and student perceptions of blended learning in four secondary mathematics classrooms. In Mathematics Education Research Journal. https://doi.org/10.1007/s13394-020-00359-2

Ellis, R. A., Calvo, R. A., Journal, S., Ellis, R. A., \& Calvo, R. A. (2007). International Forum of Educational Technology \& Society Minimum Indicators to Assure Quality of LMSsupported Blended Learning Published by: International Forum of Educational Technology \& Society Stable URL: https://www.jstor.org/stable/10.2307/jeducte. Journal of Educational Technology \& Society, 10(2), 60-70.

Fathema, N., \& Akanda, M. H. (2020). Effects of instructors' academic disciplines and prior experience with learning management systems: A study about the use of Canvas. Australasian Journal of Educational Technology, 36(4), 113-125. https://doi.org/10.14742/AJET.5660

Instructure (2019). The learning platform that helps great education happen. Retrieved from https://www.instructure.com/canvas/

Montague, M., Krawec, J., Enders, C., \& Dietz, S. (2014). The effects of cognitive strategy instruction on math problem solving of middle-school students of varying ability. Journal of Educational Psychology, 106(2), 469.

Woodward, J., Beckmann, S., Driscoll, M., Franke, M., Herzig, P., Jitendra, A., Koedinger, K. R., \& Ogbuehi, P. (2012). Improving Mathematical Problem Solving in Grades 4 
through 8. IES Practice Guide. NCEE 2012-4055. What Works Clearinghouse.

Zhang, L., Jackson, H. A., Hunt, T. L., Carter, R. A., Yang, S., \& Emerling, C. R. (2021). Maximizing Learning Management Systems to Support Mathematical Problem Solving in Online Learning. Teaching Exceptional Children, 1-10. https://doi.org/10.1177/0040059921996730 


\title{
UPAYA MENEKAN RESIKO LEARNING LOSS MELALUI PEMBELAJARAN TATAP MUKA TERBATAS
}

\author{
Dr. Sholihatul Hamidah Daulay, S.Ag., M.Hum. ${ }^{18}$ \\ (Universitas Islam Negeri Sumatera Utara)
}

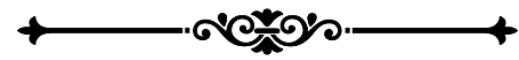

"Mencegah terjadinya learning loss dengan cara melakukan tatap muka terbatas, dengan mematuhi protokol kesehatan secara ketat"

\section{Latar Belakang}

Cejak diberlakukannya Pembelajaran Tatap Muka (PTM) Terbatas pada beberapa sejumlah daerah di Indonesia setelah kurang lebih 2 tahun peserta didik belajar secara daring, diyakini hal ini sebagai langkah awal untuk menjaga kualitas pembelajaran siswa Indonesia serta menjaga kesiapan mental agar kembali belajar secara tatap muka di sekolah. Namun demikian, kita harus tetap memperhatikan keselamatan peserta didik dalam rangka mendukung PTM Terbatas ini. Pada pelaksanaan PTM Terbatas ini harus dipahami sebaik mungkin karena bukan berarti melepaskan anak/peserta didik ke sekolah dengan begitu saja akibat orang tua yang telah letih mendampingi proses belajar

18 Penulis lahir di Surabaya, 22 Juni 1975, penulis adalah Dosen UIN Sumatera Utara dalam bidang ilmu Linguistik, penulis menyelesaikan gelar Sarjana Tadris Bahasa Inggris di IAIN Sumatera Utara (1999), gelar Magister Humaniora diselesaikan di Universitas Sumatera Utara Program Studi Linguistik (2002), dan gelar Doktor Ilmu Linguistik diselesaikan di Universitas Sumatera Utara Fakultas Ilmu Budaya Program Studi Linguistik (2014). 
mengajar yang dilaksanakan secara daring, namun yang perlu diperhatikan juga adalah potensi paparan Covid-19 ketika mereka berkerumun dan berkumpul di dalam kelas dengan teman-temannya. Peranan aktif orang tua sangat penting dalam memahami serta memastikan bahwa anak-anaknya siap dalam mengikuti PTM Terbatas di sekolah sesuai protokol kesehatan.

Di sisi lain pelaksanaan PTM Terbatas ini dilakukan oleh pemerintah sebagai upaya untuk menekan terjadinya risiko learning loss, akan tetapi di sisi lain pula pelaksanaan ini juga harus mengedepankan keselamatan para peserta didik itu sendiri, dan jangan malah menjadi bumerang bagi peserta didik karena menimbulkan penularan kluster baru Covid-19. Dalam hal ini jika sekolah-sekolah yang akan melaksanakan PTM Terbatas, maka pemerintah memberikan beberapa persyaratan yang ketat mulai dari protokol kesehatan hingga sarana dan prasarana dalam mendukung kegiatan belajar mengajar berlangsung. Pihak sekolah juga harus mengantisipasi adanya kemungkinan para peserta didik yang tidak menunjukkan gejala (OTG) tapi sebagai pembawa virus dan bisa menularkan ke pihak pemangku kepentingan sekolah yang lainnya seperti guru-guru dan staf administrasi sekolah lainnya.

Di samping itu, munculnya learning loss adalah merupakan suatu konsep yang diartikan sebagai adanya ketidakmaksimalannya pada proses pembelajaran yang dilaksanakan di suatu sekolah (Li et al., 2020). Ketidakmaksimalnya proses pembelajaran ini juga akan berdampak terhadap hasil informasi dan hasil belajar siswa yang tidak maksimal pula. Dengan demikian secara tidak langsung, timbulnya learning loss ini akan dapat berdampak pada kualitas sumber daya manusia yang lahir di tahun-tahun selama pandemi Covid-19 ini (Kashyap et al., 2021; Yadav, 2021; Zakharova et al., 2021). 


\section{Pengertian Learning Loss}

Selama proses pembelajaran daring dilakukan telah banyak terjadi hambatan dan kendala yang sangat berarti, bukan saja pada guru akan tetapi pada peserta didik juga. Perubahan kebiasaan dalam persiapan mengajar yang awalnya tatap muka ke daring atau online bukanlah sesuatu yang mudah bagi guru, karena tidak semua guru memiliki ketrampilan tersebut. Ada beberapa materi pembelajaran yang agak sulit disampaikan secara daring, sehingga banyak yang kesulitan serta tidak mengerti dengan materi tersebut. Pada masa pandemi saat ini telah banyak terjadi perubahan dari berbagai aspek baik di bidang ekonomi, sosial, budaya, pendidikan dan politik, kondisi learning loss ini adalah merupakan dampak dari penutupan sekolah selama masa pandemi. Munculnya permasalahan pada pembelajaran tersebut juga akan mengakibatkan munculnya learning loss atau berkurang bahkan hilangnya minat belajar pada siswa.

Istilah learning loss adalah suatu istilah yang mengacu pada terjadinya kemunduran atau hilangnya pengetahuan serta ketrampilan pada suatu proses akademik yang disebabkan oleh suatu kondisi. Menurut Menteri Komunikasi dan Informatika, Johnny G Plate (2021) menyebutkan bahwa risiko learning loss pada anak-anak terus menguat, hal ini disebabkan karena kegiatan proses belajar mengajar yang terpaksa dilakukan secara daring untuk menghindari penyebaran covid-19. Peserta didik bila tidak memperoleh pembelajaran yang optimal secara berkesinambungan serta mengalami kemunduran baik secara akademis dan nonakademis adalah bagian dari risiko learning loss juga, dan bisa membutuhkan waktu hingga 9 tahun dalam proses pemulihannya.

Menurut The Education and Development Forum (2020), learning loss adalah suatu situasi dimana peserta didik telah kehilangan keterampilan dan pengetahuannya ataupun kemunduran secara akademis, akibat adanya kesenjangan yang berkepanjangan atau ketidak berlangsungannya proses 
pendidikan akibat peristiwa luar biasa. Sementara itu, penggunaan kata learning loss di luar negeri didefinisikan sebagai fenomena yang terjadi pada anak-anak dari golongan ekonomi menengah ke bawah dimana mereka memang tidak punya kemampuan dan kelebihan untuk menggunakan serta mengakses gawai atau internet untuk belajar. Di Indonesia sendiri penggunaan learning loss itu adalah fenomena di mana sebuah generasi kehilangan akan kesempatan menambah ilmu karena ada penundaan proses belajar mengajar. Namun demikian di masa pandemi sekarang ini, resiko learning loss memang sangat besar terjadi dan banyak hal yang harus kita lakukan untuk mengatasi learning loss ini terjadi, apalagi dengan adanya kemajuan teknologi di era digital saat ini (Fairuz \& Yusof, 2017; Maemunah, 2018).

Adanya risiko learning loss memang sudah diprediksi sebelumnya akan terjadi sejak awal terjadinya penutupan sekolah-sekolah di seluruh antero dunia akibat pandemi Covid-19 ini. Berdasarkan laporan tentang wacana pembukaan kembali seluruh sekolah yang dikeluarkan atas inisiatif bersama oleh UNESCO, UNICEF, World Bank, dan WFP pada bulan April 2020, dinyatakan bahwa penutupan sekolah secara global sebagai tanggapan terhadap pandemi tersebut menghadirkan serta menimbulkan suatu risiko besar dan vital yakni dapat merusak perlindungan, pendidikan, maupun kesejahteraan anak-anak (Masterman, 2020).

Dilain sisi, ini merupakan hal yang sangat rumit mengenai permasalahan buka dan penutupan sekolah, karena pada dasarnya penutupan sekolah seharusnya menjadi pilihan terakhir dalam pengendalian serta mengatasi penyebaran pandemi. Sekolah sangat penting sekali dan ini tidak saja terkait dengan pendidikan anak akan tapi juga terhadap kondisi mental anak-anak itu sendiri. Menurut data dari Donnelly \& Patrinos, 2021; Engzell et al., 2021, ada beberapa masalah yang timbul diakibatkan oleh sekolah yang tidak melakukan tatap muka atau masih menerapkan pembelajaran daring yakni: 
1. adanya penurunan tingkat minat maupun keinginan belajar

2. meningkatnya kesenjangan

3. adanya kemungkinan kasus putus sekolah (drop out)

Dengan melihat dampak kondisi yang ada maka kita dapat mencegah terjadinya learning loss ini yaitu dengan cara melakukan tatap muka terbatas, untuk daerah dengan catatan kasus penularan covid 19 paling sedikit harus diadakan pembelajaran tatap muka terbatas dan dengan mematuhi protokol kesehatan secara ketat, setidaknya cara ini bisa meminimalisir terjadinya learning loss. Selain itu, ada strategi yang bisa ditempuh dan disesuaikan dengan kondisi masingmasing sekolah, antara lain:

1. Perlunya optimalisasi sekolah sebagai upaya untuk mendukungnya kegiatan belajar mengajar serta dukungan pada bentuk keberagaman sumber belajar saat sekolah tidak melaksanakan tatap muka. Pada dasarnya, dengan ketiadaan pembelajaran tatap muka seharusnya tidak akan mengurangi esensi pembelajaran termasuk di dalamnya adalah bagaimana sekolah dan guru masih tetap memantau sikap dan juga karakter siswa.

2. Menimbulkan kembali minat belajar peserta didik yang hilang akibat lamanya pembelajaran tanpa tatap muka terutama terkait pencapaian pengetahuan dan keterampilan siswa. Hal ini dapat dilakukan dengan cara memberikan jam tambahan untuk peserta didik yang jauh tertinggal pelajarannya dengan tetap memperhatikan protokol kesehatan.

\section{Kesimpulan}

Pembelajaran Tatap Muka terbatas harus dilakukan secepatnya karena pelaksanaan Pembelajaran Jarak Jauh (PJJ) yang sangat berkepanjangan bisa menimbulkan risiko negatif pada peserta didik. Ada tiga alasan utama yang menjadi dasar 
pelaksanaan PTM terbatas ini. (1) untuk menghindari ancaman putus sekolah. Dalam hal ini, PJJ yang tidak maksimal pelaksanaannya membuat anak terpaksa bekerja dan tidak belajar guna membantu keuangan keluarga di tengah krisis pandemic, (2) untuk menghindari penurunan capaian belajar anak. Pembelajaran di kelas ternyata diyakini lebih dapat menghasilkan pencapaian akademik lebih baik jika dibandingkan dengan PJJ, (3) guna menghindari adanya risiko psikososial ataupun kondisi individu yang mencakup aspek psikis dan sosial pada anak selama PJJ. Adapun risiko yang terjadi meliputi peningkatan risiko pernikahan dini, kekerasan fisik dan mental pada anak di rumah, eksploitasi anak terutama perempuan, serta munculnya kehamilan remaja yang tinggi.

\section{Daftar Pustaka}

Andriani, W., Subandowo, M., Karyono, H., Gunawan, W., (2021). Learning Loss dalam Pembelajaran Daring di Masa Pandemi Corona. Seminar nasional Teknologi Pembelajaran. Universitas Negeri Malang

Donnelly, R., \& Patrinos, H. A. (2021). Learning Loss During Covid-19: An Early Systematic Review. Covid Economics Vetted and Real-Time Papers, 77.

Engzell, P., Frey, A., \& Verhagen, M. D. (2021). Learning Loss Due to School Closures During the Covid-19 Pandemic. Proceedings of the National Academy of Sciences of the United States of America, 118(17). https://doi.org/10.1073/PNAS.2022376118

Fairuz \& Yusof. (2017). Revolusi Perindustrian Keempat/The Fourth Industrial Revolution. I'm M. Fairuz.

Kashyap, A. M., Sailaja, S. V., Srinivas, K. V. R., \& Raju, S. S. (2021). Challenges in online teaching amidst covid crisis: Impact on engineering educators of different levels. Journal of Engineering Education 
Transformations, 34

(Special Issue). https://doi.org/10.16920/jeet/2021/v34i0/157103

Li, A., Harries, M., \& Ross, L. F. (2020). Reopening K-12 Schools in the Era of Coronavirus Disease 2019: Review of State-Level Guidance Addressing Equity Concerns. Journal of Pediatrics, 227. https://doi.org/10.1016/j.jpeds.2020.08.069

Yadav, R. (2021). Cyber Security Threats During Covid-19

Pandemic. International Transaction Journal of Engineering Management \\& Applied Sciences I\& Technologies, 12(3).

Zakharova, U. S., Vilkova, K. A., \& Egorov, G. V. (2021). It Can't Be Taught Online: Applied Sciences Students during the Pandemic. Voprosy Obrazovaniya, 2021(1). https://doi.org/10.17323/1814-9545-2021-1-115-137 


\title{
SERBA-SERBI PELAKSANAAN PEMBELAJARAN TATAP MUKA TERBATAS (PTMT)
}

\author{
Susana Labuem, M.Pd. ${ }^{19}$ \\ (Universitas Pattimura PSDKU ARU)

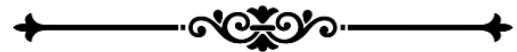

"Pembelajaran jarakjauh (PJJ) memang diperlukan untuk menurunkan risiko penularan Covid-19, namun menimbulkan

tantangan seperti ketimpangan fasilitas/akses teknologi sehingga proses pembelajaran kurang optimal. Oleh karena itu,

Pembelajaran Tatap Muka Terbatas (PTMT) mulai dilaksanakan secara bertahap di Indonesia".

\begin{abstract}
$\mathrm{H}$
arapan semua warga belajar adalah segera berlalunya pandemi Covid-19. Memang tak dapat dipungkiri bahwa dengan munculnya pandemi Covid-19 ini, bukan hanya warga belajar tetapi seluruh masyarakat dengan berbagai latar belakang ekonomi dan sosial tanpa terkecuali. Namun meski begitu, harapan setiap warga negara Indonesia tanpa terkecuali dan seluruh warga negara lain dimanapun, yaitu kiranya pandemi segera usai agar seluruh aktivitas dapat kembali berjalan secara normal tanpa dihantui oleh perasaan takut akan terpapar oleh Covid-19.
\end{abstract}

19 Penulis lahir di Longgar, 07 Oktober 1990. Penulis merupakan Dosen Pendidikan Matematika pada Universitas Pattimura Program Studi Di Luar Kampus Utama (PSDKU) di Kabupaten Kepulauan Aru. Penulis menyelesaikan gelar Sarjana di Universita Pattimura Program Studi Pendidikan Matematika (2013). Selanjutnya menyelesaikan gelar Magister di Universitas Negeri Malang Jurusan Matematika (2019). 
Dengan mempertimbangkan kondisi terkini terkait dengan jumlah kasus Covid-19 yang mulai menurun, sudah dilakukannya vaksinasi tahap 1 dan tahap 2, dan dengan mempertimbangkan pengalaman kurang lebih satu sampai dua tahun yang lalu, dimana sekolah mesti diliburkan dan aktivitas pembelajaran mesti dilakukan secara online merupakan data akurat dan bukti valid bahwa pembelajaran secara tatap muka di sekolah memang lebih maksimal jika dibandingkan dengan pembelajaarn secara online. Pemerintah kemudian mengeluarkan kebijakan terbaru tentang sistem pelaksanaan Pembelajaran Tatap Muka Terbatas (PTMT).

Pemberlakuan PTMT memiliki alasan tersendiri dan dapat dipertanggungjawabkan. Sudah sekitar satu sampai dua tahun lebih sejak pandemi merebak di Indonesia, kegiatan pembelajaran dilaksanakan secara jarak jauh (PJJ). Pembelajaran jarak jauh (PJJ) diterapkan dengan tujuan dapat mengurangi jumlah kasus Covid-19 di Indonesia yang merupakan bagian dari dunia global. Tak dipungkiri bahwa akan selalu ada tantangan yang timbul seperti ketimpangan fasilitas/akses teknologi untuk pembelajaran daring sehingga proses pembelajaran kurang optimal. Oleh karena itu, PTMT mulai dilaksanakan secara bertahap di Indonesia.

Baik dalam PTMT maupun PJJ berbasis daring, luring dan blended Learning, proses pembelajaran harus mengikuti beberapa prinsip berikut ini: (1) kesehatan dan keselamatan peserta didik, pendidik dan tenaga kependidikan adalah yang pertama dan utama; (2) sekalipun dalam suasana menghadapi pandemi Covid-19 dengan segala keterbatasannya, bukan berarti proses pembelajaran dilaksanakan seenak dan seperlunya, melainkan proses pembelajaran tetap diusahakan berjalan efektif; dan (3) proses pembelajaran dilaksanakan tanpa diskriminatif. Ada pendapat mengatakan bahwa, "Sekalipun siswa tidak mengalami pembelajaran efektif lost learning) akibat atau dampak Covid-19 tidaklah berarti siswa kita menjadi bodoh secara permanen untuk selama-lamanya, 
melainkan masih bisa diperbaiki atau bisa dididik ulang (reeducating).

Sementara, proses pembelajaran jarak jauh berbasis daring, luring dan blended learning selama ini belum berjalan efektif. Memperhatikan kondisi seperti ini, dapat dipahami sebagian orang tua dan siswa untuk ingin secepatnya kembali pada pembelajaran tatap muka. Memperhatikan kondisi pandemik Covid-19 saat ini, sesungguhnya kita belum siap untuk memulai pembelajaran tatap muka secara masif, Namun PTMT dapat saja dilaksanakan. Asumsi tersebut di atas didasarkan pada pendapat William Bridge (2005) dalam bukunya; "Managing Transitions" bahwa sesungguhnya masalah kita hingga saat ini bukanlah kurang dan rumitnya perubahan itu, melainkan ketidakefektifan mengelola setiap fase perubahan.

Setidaknya ada dua fase perubahan yang harus dilalui sebelum melakukan fase permulaan baru (new normal), yakni fase pertama: fase pengakhiran, kemudian dilanjutkan fase kedua, yakni fase transisi, yakni suatu proses dimana orang keluar dari dunia lama dan masuk ke dunia baru atau dimulai dengan suatu pengakhiran dan diakhiri dengan suatu permulaan. Permulaan sangat tergantung pada pengakhiran, Namun sayangnya banyak orang tidak suka mengakhirinya, karena telah terperangkap dalam "zona nyaman" atau tersandera oleh sebuah pola pikir, sikap dan kebiasaan yang tidak mendukung sebuah perubahan. Kita paksakan secara bertahap memasuki fase kedua (fase transisi) dimana pemerintah merencanakan PTMT. Akan tetapi harus diingat bahwa jika gagal melaksanakan perubahan di fase transisi tersebut, maka kita akan terpuruk jauh ke jurang dan sangat sulit untuk kembali bangkit menuju fase permulaan baru (new normal), sebaliknya jika berhasil menjalani fase transisi tersebut, maka tidak mustahil akan terjadi lompatan yang sangat cepat menuju fase permulaan baru (new normal). Itulah sebabnya, penulis memandang pentingnya 
mempersiapkan dan melaksanakan program PTMT tersebut dengan sebaik-baiknya.

Dasar pertimbangan berikutnya, Sonny Harry B. Harmadi selaku Ketua Bidang Perubahan Perilaku Satgas Penanganan Covid-19 menegaskan bahwa "Penanganan Covid-19 tidak cukup hanya bergantung pada upaya kesehatan, seperti vaksinasi dan pengobatan. Penelitian membuktikan, 99\% resiko penularan dapat dicegah melalui perilaku atau kebiasaan (disiplin) masyarakat melaksanakan protokol kesehatan.

Berdasarkan pertimbangan-pertimbangan yang telah diuraikan sebelumnya di atas, PTMT dapat dilaksanakan dengan mempertimbangkan beberapa hal berikut ini: (1) bangunkan kesadaran dan komitmen bersama orang tua, sekolah dan masyarakat untuk mensukseskan PTMT; (2) mempersiapkan pembelajaran tatap muka dengan mempertimbangkan aspek epidemiologi, sistem kesehatan dan surveilans yang tidak sama di setiap daerah guna memastikan lingkungan sekolah sudah dalam keadaan aman; (3) disiplin melaksanakan protokol kesehatan, antara lain: menjaga jarak, memakai masker, mencuci tangan dengan sabun dan air mengalir, tidak berkerumun, dan tetap menjaga pola hidup sehat dan bersih; (4) dilakukan PTMT secara bertahap dengan melibatkan (kolaborasi) stakeholder sekolah; (5) melakukan monitoring dan evaluasi terhadap PTMT.

\section{Syarat Pembelajaran Tatap Muka Terbatas}

Pembelajaran tatap muka dapat dilaksanakan dengan persyaratan (1) sekolah memenuhi kriteria lulus asesmen 1 tentang kesiapan Satuan Pendidikan (SP) dan asesmen 2 tentang Belajar dari Rumah (BDR); (2) sekolah memenuhi verifikasi; dan (3) guru dan kepala sekolah lulus pelatihan. Sekolah yang memenuhi tiga persyaratan tersebut akan ditetapkan oleh Dinas Pendidikan sebagai sekolah yang boleh melaksanakan pembelajaran tatap muka. Adapun 
peserta didik yang dapat mengikuti pembelajaran tatap muka adalah yang telah divaksin, berusia 12 tahun ke atas, dan mendapat izin orang tua. Murid yang belum divaksin/tidak mendapat izin orang tua, disarankan mengikuti pembelajaran jarak jauh.

Selanjutnya, Dinas Pendidikan akan melakukan pemantauan secara berkala. Pemberhentian kegiatan PTMT dapat dilakukan bila ditemukan warga sekolah yang terpapar Covid-19, pelaksanaan PTM tidak sesuai dengan aturan yang seharusnya. Bagaimana bila ada warga sekolah yang terpapar Covid-19? PTM akan dihentikan selama 3 hari, lalu tracing dilakukan kepada warga sekolah, dan sekolah akan disinfeksi.

\section{Upaya Pengetatan Protokol Kesehatan Selama PTMT}

Ada beberapa upaya yang wajib dilakukan sekolah dan seluruh warga sekolah selama PTMT berlangsung:

1. Pemberian tanda antrean/larangan duduk pada beberapa fasilitas sekolah seperti tempat duduk, lantai selasar, antrean pintu masuk, antrean wastafel, halaman sekolah, dan lainnya;

2. Pemasangan spanduk/banner sebagai pengingat agar menjaga protokol kesehatan;

3. Bimbingan oleh guru dan tenaga didik kepada siswa agar menjaga jarak serta mengikuti protokol kesehatan lainnya;

4. Pemantauan oleh guru, tenaga didik, dan Satgas Covid-19 di sekolah;

5. Pembatasan kapasitas siswa maksimal 50\% dan penggantian jadwal setiap kelas.

Untuk pembelajaran tatap muka, sekolah pun wajib mengikuti peraturan terkait kapasitas kelas, sirkulasi udara, durasi belajar, ketersediaan fasilitas, kelengkapan vaksinasi Covid-19 pada guru dan petugas sekolah sesuai dengan 
panduan Ikatan Dokter Anak Indonesia (IDAI) terkait pembukaan sekolah.

Agar PTMT semakin berjalan lancar dan aman, diperlukan juga kejujuran bagi guru, perangkat sekolah, serta orang tua siswa mengenai kondisi kesehatan masing-masing dan tidak menutupi jika terinfeksi Covid-19. Pemerintah setempat maupun sekolah pun mesti transparan untuk menampilkan data kasus Covid-19 pada siswa. Data dapat difasilitasi melalui dashboard di data nasional Covid-19 masing-masing daerah dan tingkat sekolah. Selama PTMT berlangsung, perlu diadakan juga evaluasi mingguan oleh sekolah, Pemerintah Daerah, Dinas Kesehatan, serta Dinas Pendidikan untuk memutuskan pembukaan/penutupan sekolah dengan memperhatikan kasus harian Covid-19 pada warga sekolah.

\section{PTMT Jangan Sampai Membebani Psikologi Anak}

Dalam pelaksanaan PTMT, terdapat berbagai hal mendasar yang mesti mendapat perhatian serius dari setiap guru, yaitu muatan materi tidak mesti dipaksakan atau terkesan mengejar ketertinggalan materi pelajaran. Para siswa mesti dicek dulu secara psikologis, diberikan motivasi tentang kesehatan. Pastikan para siswa mematuhi protokol kesehatan. Ketika anak-anak di sekolah akan lebih mudah dikontrol karena sehari hanya empat jam dan jumlah mereka sedikit.

Selain itu juga, penting untuk para guru menjaga agar jangan sampai terjadi diskriminasi pada siswa yang masih memilih untuk belajar dari rumah. Baik terkait materi pelajaran ataupun dalam pemberian nilai. Materi yang diberikan sesuai dengan kondisi anak. "Tidak boleh memberi soal yang sama pada siswa tatap muka dan PJJ, karena pemahamannya pasti berbeda. Berikan evaluasi sesuai kondisi siswa, ini penting agar para siswa tidak merasa takut.

Selain kepada guru, penting bagi kepala sekolah untuk mengatur pembelajaran di sekolah dengan baik. Saat PTMT berlangsung siswa cukup diberikan materi-materi yang esensial. Apalagi, lanjutnya, sebagian besar waktu belajar 
siswa adalah di rumah. Dalam seminggu hanya dua hari ke sekolah, empat harinya di rumah.

\section{Pembelajaran Tatap Muka Menurut Pandangan Ikatan Dokter Anak Indonesia (IDAI)}

IDAI turut memberikan pandangannya terkait kebijakan pembelajaran tatap muka. Menurut IDAI, setidaknya, ada tiga poin pertimbangan pelaksanaan PTMT, yaitu (1) telah dimulai vaksinasi imunisasi anak berusia 12 tahun ke atas dan usia dewasa; (2) penurunan kasus Covid-19 di beberapa daerah di Indonesia; dan (3) penutupan sekolah yang sudah berlangsung lebih dari 1 tahun. Apabila ketiga hal tersebut telah dicapai maka IDAI memberikan rekomendasi yang dapat berubah sewaktu-waktu sesuai kondisi. Berdasarkan rekomendasi IDAI, PTMT dapat dimulai secara bertahap dengan memenuhi ketentuan-ketentuan yang berlaku.

Siswa, guru, dan perangkat sekolah lainnya yang datang ke sekolah sudah harus divaksin Covid-19. Dalam memutuskan untuk pembelajaran kembali dilakukan di sekolah, orang tua dapat mempertimbangkan hal-hal berikut (1) Anak usia > 12 tahun yang sudah mendapatkan vaksin Covid-19. (2) Anak tidak ada komorbiditas (termasuk obesitas), jika terdapat komorbiditas harap mengkonsultasikan kepada dokter terlebih dahulu. (3) Anak sudah dapat memahami protokol kesehatan seperti menggunakan masker, menjaga jarak, mencuci tangan, mengetahui apa yang boleh dilakukan untuk mencegah transmisi Covid-19 dan hal yang tidak boleh dilakukan karena berisiko tertular/menularkan virus. (4) Guru dan petugas di sekolah telah mendapatkan vaksinasi Covid-19. (5) Anggota keluarga di rumah sudah mendapatkan vaksinasi Covid-19. 


\title{
IMPLEMENTASI GERAKAN SEKOLAH MENYENANGKAN (GSM) UNTUK MENUMBUHKAN KARAKTER DAN MINAT BELAJAR SISWA DALAM PERSIAPAN PEMBELAJARAN TATAP MUKA
}

\author{
Octa Prasetya Adi, M.Pd. ${ }^{20}$ \\ (SMPS 1 Bumitama Antang Kalang Yayasan Bumitama)

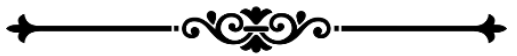

"Pendidikan melalui GSM memicu semangat tanpa memaksa siswa untuk berbuat apa-apa. Pembelajaran yang menyenangkan akan mengarah pada pembelajaran sepanjang hayat dalam gambaran adiksi yang paling sederhana"

Dendidikan adalah upaya menciptakan lingkungan belajar didik secara aktif mengembangkan potensi dirinya untuk memiliki kekuatan agama dan spiritual, pengendalian diri, budi pekerti, kecerdasan, dan akhlak mulia serta keterampilan yang diperlukan dirinya, masyarakat, bangsa, dan negara.. Pendidikan sebagai suatu kegiatan dan proses kegiatan yang disengaja menjadi ciri masyarakat. Bahkan pendidikan menjadi sangat erat kaitannya dengan teknologi yang mendukung sistem pendidikan Indonesia seiring dengan

${ }^{20}$ Penulis lahir di Banyuwangi, 22 Oktober 1995, penulis merupakan Guru di SMPS 1 Bumitama Antang Kalang Yayasan Bumitama dalam bidang ilmu Pembelajaran Olahraga dan Kesehatan, penulis menyelesaikan gelar Sarjana Pendidikan Jasmani dan Kesehatan di Universitas Negeri Malang (2017), sedangkan gelar Magister Pendidikan diselesaikan di Universitas Negeri Malang Program Studi Pendidikan Olahraga (2019). 
pentingnya upaya membentuk, mengarahkan dan mengatur manusia sesuai dengan kebutuhan masyarakat mulai disadari.

Di era pendidikan sekarang ini, tidak dapat dipungkiri bahwa pendidikan telah berkembang pesat karena adanya teknologi modern tersebut. Bahkan sistem pendidikan sebuah sekolah harus mampu beradaptasi dengan kemajuan teknologi yang pesat. Karena tidak dapat dipungkiri bahwa kemajuan teknologi dapat mempengaruhi kepribadian seorang siswa, bahkan dalam kepentingan pendidikan siswa tersebut.

Sistem pendidikan Indonesia terbayar pasca pandemi Covid19, alhasil seluruh sekolah telah menerapkan sistem Learning from Home (BDR) sesuai Surat Edaran No 1 Kemendikbud. Di masa pandemi, banyak sekolah menggunakan beberapa metode yang dapat digunakan untuk mendukung sistem pembelajaran sekolahnya dan mencapai tujuan pembelajarannya. Salah satu implementasi metode pendidikan saat ini adalah Gerakan Sekolah Menyenangkan atau GSM. Gerakan Sekolah Seru

Adalah pendekatan GSM yang berawal dari perubahan yang dialami pendiri Muhammad Nur Rizal dan istrinya Novi Poespita Chandra. Pengalaman ini didapat saat Rizal dan Novi tinggal di Melbourne, Australia untuk meraih gelar $\mathrm{PhD}$. Mereka mendapat inspirasi dari ketiga anaknya yang sangat mencintai sekolah. Di sini mereka melihat pendidikan Australia yang sangat berbeda dari pendidikan Indonesia. Bisa dikatakan pendidikan Indonesia tertinggal 128 tahun dari pendidikan Australia. Pendidikan Australia berbeda karena kurikulumnya lebih baik dan lebih menyenangkan serta disesuaikan dengan kekuatan masing-masing anak. Bahkan, anak-anaknya justru bolos sekolah saat liburan. Inspirasi ini dimulai pada tahun 2016 ketika saya kembali ke Indonesia untuk membangun GSM. Rizal dan Novi prihatin dengan pendidikan Indonesia yang justru membuat belajar lebih menyenangkan bagi anak-anak, namun tetap menentukan nilai dan ujian. Bahkan, GSM menyasar sekolah 
luar kampus yang tidak mendapat perhatian pemerintah. Tujuannya adalah untuk meningkatkan kualitas sekolah di luar kampus. Gerakan Sekolah Menyenangkan (GSM) adalah pendekatan alternatif yang diyakini sesuai dengan cita-cita Baoak Pendidikan Indonesia, Ki Hadjar Dewantara, sebuah organisasi Indonesia untuk menciptakan taman siswa sekolah yang memenuhi kebutuhan siswa SD hingga SMA. Penelitian yang ada menunjukkan bahwa GSM meningkatkan kesadaran dan meningkatkan kesadaran di kalangan guru, sekolah dan pembuat kebijakan pendidikan untuk menjadikan sekolah tempat yang menarik untuk belajar sains dan keterampilan hidup. GSM telah menjadi program pendidikan inovatif yang berupaya mengubah model pendidikan formal menjadi keterampilan anak yang lebih partisipatif, inklusif dan bermanfaat. Menurut John Suey, dengan bantuan GSM, siswa dapat mengembangkan karakter dan meningkatkan minat belajar.John Suey mengatakan bahwa pendidikan karakter merupakan tujuan bersama dari pendidikan karakter dan persekolahan. Dan ketika Anda mendapat dukungan dan dorongan dari orang-orang di sekitar Anda, kekuatan karakter Anda akan muncul secara alami. Peran keluarga, sekolah, dan masyarakat sangat penting untuk menjaga dan membangun kekuatan karakter.

Mengetahui bahwa pendidikan di Indonesia masih terfokus pada metode pengajaran yang membuat Anda bosan ketika pergi ke sekolah, sulit untuk bahkan menganggap bahwa sekolah sangat menakutkan karena Anda harus mengambil kelas yang membosankan agar tertarik untuk belajar. Dan tanpa disadari, banyak sekolah yang gagal menggali potensi setiap siswa. Karena berbagai penelitian menunjukkan bahwa GSM membuat perbedaan mendasar dalam pendidikan, ada kebutuhan untuk mengembangkan program latihan sekolah yang menyenangkan di setiap sekolah untuk mempersiapkan siswa menghadapi pembelajaran tatap muka. GSM bukan hanya tentang belajar, itu yang digunakan siswa untuk mempelajari sesuatu. Proses 
pembelajaran menjadi lebih terbuka dan menyenangkan. Mubarak mengatakan pengenalan pendidikan melalui GSM memicu semangat tanpa memaksa siswa untuk berbuat apaapa. Pembelajaran yang menyenangkan akan mengarah pada pembelajaran sepanjang hayat dalam gambaran adiksi yang paling sederhana, seperti misalnya anak-anak yang kecanduan game gadget atau orang yang menggunakan media sosial.

Dengan demikian, kita dapat menyimpulkan bahwa kita membutuhkan gerakan "sekolah yang menyenangkan" untuk mempersiapkan pendidikan penuh waktu. Hal ini dikarenakan GSM sendiri lebih menitikberatkan pada karakter dan materi anak serta pelajaran yang dipetik darinya. Tidak ada asumsi lagi karena siswa dapat menerapkannya sendiri, minat belajar anak dapat lebih semangat, dan efek positif dari GSM adalah membuat proses belajar menjadi lebih aktif dan menarik tanpa siswa bosan belajar.

\section{Daftar Pustaka}

Dani Kurniawan. 2018. Komunikasi Model Laswell Dan Stimulus-Organism-Response Dalam Mewujudkan Pembelajaran Menyenangkan. Jurnal Komunikasi Pendidikan 2, no. 1 (2018): 60 , https://doi.org/10.32585/jkp.v2i1.65.

Saihu, Made. 2021. Pola Gerakan Sekolah Menyenangkan (Gsm) Di Madrasah Ibtidaiyah Al-Husna Pondok Aren Tangerang Selatan. Al Amin: Jurnal Kajian Ilmu dan Budaya Islam. Vol 4, No. 01

Yohanes Enggar Harususilo, "Dorong Potensi Siswa lewat," 2019.

Zaki Mubarak. Sistem Pendidikan Di Negri Kanguru. I. Depok: Ganding Pustaka Depok, 2019. 
Zaki Mubarak, Sistem Pendidikan Di Negri Kanguru, 315 


\title{
EFEKTIVITAS WAKTU PADA PEMBELAJARAN TATAP MUKA TERBATAS (TMT)
}

\author{
Dede Risma Ginanjar, S.Pd. ${ }^{21}$ \\ (SD Aisyiyah Kota Sukabumi)

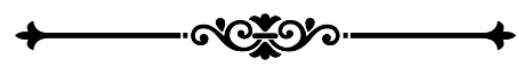

"Sebagai guru yang professional harus mampu mengelola waktu secara maksimal dengan mengemas pembelajaran yang kreatif dan inovatif, dimana selama pembelajaran harus sudah memuat tujuan pembelajaran yang sudah dirancang sebelumnya"

Delaksanaan tatap muka terbatas (PTMT) diseluruh satuan
pendidikan sudah mulai dilaksanakan sejak Juli 2021,
berdasarkan keputusan menteri pendidikan dan kebudayaan,
yang terkait dengan pandemic Covid-19. Pelaksanaan
Pembelajaran TMT ini dilaksanakan berdasarkan
pertimbangan pertama semua pendidik dan pesertadidik
sudah melaksanakan Vaksin dan selama pembelajaran jarak
jauh ternyata pendidikan di Indonesia mengalami penurunan,
sehingga tertinggal jauh dari Negara lain.

Dari pembelajaran daring banyak belajar bahwa pendidikan itu tidak hanya dilakukan secara tatap muka, dengan keterbatasan jarak dan kondisi pun pendidikan masih

${ }^{21}$ Penulis lahir di Sukabumi, 09 September 1996, penulis merupakan Guru Sekolah Dasar Di SDS Aisyiyah Kota Sukabumi, penulis menyelesaikan gelar Sarjana Pendidikan Guru Sekolah Dasar di Universitas Muhammadiyah Sukabumi (2019), dan sekarang sedang menempuh gelar Megister pada Program Studi Pendidikan Dasar di Universitas Muhammadiyah Prof Dr. Hamka. 
tetap bisa dilaksanakan tanpa mengurangi esensi dari proses belajar itu sendiri. Guru sebagai pelaku utama proses pendidikan pun mulai menyadari kebutuhannya untuk mengupgrade kemampuanya dengan tantangan pendidikan di era yang serba digital ini. Guru harus mampu merangkai proses pembelajaran sedemikian rupa supaya tetap menarik dan tentunya tidak membuat anak-anak jenuh karena keterbatasan kondisi yang ada.

Selama pembelajaran daring pun guru, pesertadidik dan orangtua tentunya banyak belajar dan sama-sama menjalankan tantangan yang dihadapi selama pembelajaran daring. Dengan adanya keputusan menteri pendidikan dan kebudayaan, peihal keputusan pembelajaran TMT ini, tentunya tidak terlepas dari tantangan yang dihadapi. Seperti penyesuaian aktivitas pembelajaran yang dilakukan dalam waktu terbatas.

Berdasarkan pengalaman saya dalam pembelajaran TMT justru banyak sekali tantangan yang harus dihadapi oleh guru, dengan waktu yang diberikan 4 jam selama pembelajaran harus bisa menyampaikan semua materi pembelajaran pada setiap harinya. Pada pembelajaran TMT ini guru harus bisa mengelola waktu dengan baik, dimana pada pembelajaran TMT ini guru dan pesertadidik harus menyesuaikan dari kebiasaan pembelajaran daring ke tatap muka.

Terlebih di sekolah swasta, dimana sebelum pemebajaran dimulai pesertadidik harus melakukan pembiasaan terlebih dahulu, untuk melakukan pembiasaan ini guru biasanya membutuhkan waktu 1 jam mulai dari membaca doa, melaksanakan shalat duha, dan murojaah. Selain itu pengondisian pesertadidik sebelum pembelajaran juga terkadang membutuhkan waktu yang cukup, apa lagi kelas rendah. Jika mengacu pada tujuan pembelajaran yang harus di capai mungkin tidak akan tercapai secara maksimal karena keetrbatasan waktu, maka dari itu guru sebelum melaksanakan pembelajaran TMT sudah menyiapkan 
kurikulum selama TMT. Hal ini untuk memudahkan guru selama pembelajaran,

Adapun kurikulum yang saya rancang atau yang saya gunakan untuk pembelajaran tatap muka terbatas ini adalah dengan menganalisis KD terlebih dahulu, materi mana yang harus disampaikan, dan materi mana yang bisa disisipkan dalam pembiasaan, contohnya materi ungkapan permintaan maaf, permintaan tolong dan ucapan terimakasih. Untuk materi tersebut saya tidak menyampaikannya dalam pembelajaran, akan tetapi saya menyisipkannya dalam pembiasaan supaya anak mempraktikkannya secara langsung. Dengan seperti ini tujuan pembelajarannya tetap tersampaikan dan tentunya sangat efektif.

Selain itu ada beberapa mata pelajaran yang jadwalnya 2 minggu satu kali pertemuan, seperti mata pelajaran PJOK, karena keterbatasan waktu. Bukan kami tidak mementingkan mata pelajaran ini, akan tetapi mata pelajaran PJOK ini bisa dilaksanakan 2 minggu satu kali, karena untuk kegiatan olaharaga ini bisa dilakukan di hari libur bersama orangtua dan keluarga, tenntunya tidak terlepas dari pantauan guru. Pesertadidik dan orangtua selalu melaporkan kegiatan olahraga setiap minggunya. Ketika pembelajarannya sudah normal kembali maka jam pembelajaran pun akan kembali sebagaimana mestinya.

Selama pembelajaran TMT ini guru lebih menekankan kepada pembentukan pendidikan karakter pesertadidik, dimana selama pembelajaran daring ini pesertadidik kehilangan control terutama perihal kedisiplinan. Maka dari itu penerapan pendidikan karakter ini sangat penting ditumbuhkan kembali pada diri pesertadidik.

Seperti halnya, etika ketika berbicara, pesertadidik ketika berbicara dengan temannya ataupun gurunya, pesertadidik belum bisa membedakan. Selain itu bahasa yang mereka pergunakan seperti bahasa yang kurang sopan dan baik jika di pergunakan anak sekolah. Ini menjadi tugas guru untuk 
mengarahkan dan membimbing pesertadidik. sebisa mungkin guru mengingatkan dan memberikan contoh tentunya supaya pesertadidik memiliki karakter yang baik dan perilaku yang baik.

Dengan adanya pembelajaran tatap muka terbatas ini meskipun dengan keterbatasan waktu, akan tetapi guru menggunakan waktu semaksimal mungkin dan mengemas pembelajaran sebaik mungkin. Mengemas pembelajaran yang kreatif dan inovatif, supaya peserta didik tidak merasa bosan dan jenuh ketika belajar di dalam kelas. Dengan adanya tatap muka terbatas ini respon orang tua sangat baik, dengan alasan yang terpenting anak bisa bersosialisasi dengan teman-temannya, mengenal ibu bapak gurunya, dan mengenal lingkungan sekolahnya. Dengan waktu keterbatasan waktu yang diberikan pun, para orangtua dan pesertadidik sudah merasa senang, meskipun orantua tidak banyak menuntut perihal waktu yang diberikan, akan tetapi kami sebagai guru merasa masih kurang optimal dan efektif dengan keterbatasan waktu tersebut.

Setiap tindakan yang dilakukan pasti sudah beserta risikonya, akan tetapi sebagai guru yang professional harus bisa mengelola waktu secara maksimal, dimana selama pembelajaran harus sudah memuat tujuan pembelajaran yang sudah dirancang sebelumnya. Seperti yang sudah disampaikan diatas bahwa materi yang bersifat umum bisa disisipkan dalam pembiasaan perilaku pesertadidik maka hal tersebut akan lebih efektif. 


\section{INTEGRASI NILAI MULTIKULTURAL DALAM PEMBELAJARAN PESANTREN PASCAPANDEMI}

Siyono, M.Pd.I. ${ }^{22}$

(IAIN Salatiga)

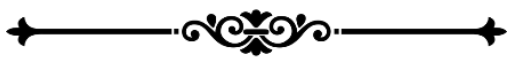

"Pesantren bisa mengintegrasikan nilai-nilai multikultural sesuai dengan konsep-konsep yang telah ditentukan yang dapat diterapkan dalam sehari-hari untuk mencetak generasigenerasi yang humanisme"

$\mathrm{P}$ esantren adalah lembaga pendidikan Islam non formal tertua di negara Indonesia. Oleh karenanya, pesantren sedang berbenah diri dalam mengembangkan pendidikan di Indonesia. Pesantren juga ikut andil dalam lini perkembangan pendidikan, dengan kewajiban konstitusional untuk mencerdaskan anak bangsa pada khususnya dan memberikan nilai karakter bangsa kepada generasi bangsa. Pendidikan di pesantren sangatlah padat, bisa dikatakan 24 jam tiada henti belajar. Kegiatan tersebut telah dilakukan sejak berdirinya suatu pesantren. Belajar di pesantren lebih banyak waktunya dari pada ketika belajar di rumah masing-masing (Siyono: 2021).

\footnotetext{
22 Penulis lahir di Kabupaten Semarang, 27 Juli 1986, penulis merupakan Dosen IAIN Salatiga khususnya Dosen Pendidikan Agama Islam, penulis telah menyelesaikan gelar Sarjana PAI di STAIN SALATIGA (2013), sedangkan gelar Magister Pendidikan Agama Islam diselesaikan di IAIN SALATIGA (2016), dan Sekarang Masih Study dan tercatat sebagai Mahasiswa Pascaasarjana Program Doktor Pendidikan Agama Islam di Universitas Muhamadiyah surakarta (UMS).
} 
Dalam peraturan presiden nomer 87 tahun 2017 menyampaikan penguatan pendidikan karakter merupakan gerakan dibawah tanggung jawab satuan Pendidikan untuk memperkuat karakter peserta didik melalui harmonisasi olah hati, olah rasa, olah piker, dan olah raga dengan pelibatan dan kerja sama antara satuan Pendidikan, keluarga, dan masyarakat sebagai bagian dari Gerakan Nasional Revolusi Mental (GNRM). (Peraturan Presiden No. 87 Tahun 2017).

Namun pada masa pandemi covid 19 ini mulai menggeser dan menggoyang tatanan proses pembelajaran yang biasanya berlangsung salah satu contohnya adalah pembelajaran secara tatap muka berubah menjadi pembelajaran dalam jaringan (daring) (Unicef, 2020). Perkembangan virus Covid19 membuat kebanyakan orang Indonesia khawatir, karena banyaknya orang yang terkena oleh transmisi virus. Sehingga pemerintah membuat kebijakan pembatasan sosial skala besar (PSBB) untuk mematahkan rantai atau mengurangi distribusi Covid-19 (Rindam Nasruddin: 2020). Pemerintah Indonesia melalui Menteri Pendidikan (Kemenpan; 2020) pada tanggal 12 Maret, 2020 mengumumkan liburnya semua kegiatan Pendidikandi semua Lembaga Pendidikan di negara ini telah ditunda untuk semua kegiatan kelas, acara akademik seperti konferensi, dan seminar (Muh Barid; 2020, 96-106).

Kegiatan pesantren sangat terkena dampak dari pandemi. Hal yang sangat terasa adalah tidak terlihatnya nilai-nilai karakter humanis dilingkungan pesantren, dimana nilai-nilai karakter adalah kebiasaan setiap hari belajar mengajar yang dilakukan dari pagi sampai malam. Karena masa pandemi maka di batasi dalam kegiatannya. Setelah masa sekarang pasca pandemi dan kondisi mulai membaik maka saatnya pesantren melaksanakan kegiatan seperti sebelum ada masa pandemi ada.

Dalam masa pascapandemi ini maka pesantren merencanakan proses pembelajaran secara tersetruktur dengan matang. Apalagi pesantren yang jumlah santrinya sangat banyak, tentu harus ekstra dalam mempersiapkannya. 
Maka untuk memunculkan kembali nilai-nilai humanis, yang sebagian termasuk mengandung nilai-nilai multikultural di pesantren dapat pula di terapkan beberapa alternatif pelaksanaan pembelajaran yang bisa di integrasikan mengandung nilai-nilai multikulturaldi lingkungan pesantren.

\section{Integrasi Nilai-Nilai Multikultural saat Pandemi Covid -19}

Kita tahu bahwa pendidikan di pesantren mengandung nilai-nilai kebaikan yang dilaksanakan setiap harinya. Tidak hanya melaksanakan pembelajaran yang bertujuan transformasi pengetahuan, akan tetapi juga di implementasikan setiap hari dalam kehidupan. Pola pembelajaran nilai multikultural dapat di integrasikan kedalam beberapa kegiatan di lingkungan pesantren. Beberapa nilai-nilai multikultural menurut Abdullah Ali dalam penelitiannya (Abdullah aly, 2011: 124) di pesantren yang dapat di integrasikan di lingkungan pesantren; At Ta'awuniyah, As-salam, Al-Musawah wa Al-'Adl, At-Samuh, Asukhuwwah, Al-Musyawwarah. Berikut penjelasannya:

\section{Nilai keaneragaman (At Ta'awuniyah)}

Beranekaragam di dalam pesantren merupakan sunnatullah dan implementasikan umumnya dalam kurikulum dan khususnya dalam materi ajar, kitab kuning yang dijadikan referensi dan bahasa pengantar sehari-hari. Ta'awun berasal dari bahasa Arab yaitu 'Ta'awana, Yata'aawuna, Ta'awuna, yang artinya tolong-menolong, gotong-royong, bantu-membantu dengan sesama manusia (lahsolikhah: 2002). Ta'awun suatu Sifat tolong menolong diantara sesama manusia dalam hal kebaikan dan takwa. Dalam ajaran Islam, tolong menolong adalah kewajiban setiap muslim (Siti Afiah:2015).

2. Perdamaian (As-salam)

Perdamaian diimplementasikan dalam kehidupan sehari-hari dilingkungan asrama pesantren, contohnya sholat berjamaah, dzikir bersama, dll. Pengertian 
perdamaian adalah tidak adanya kekerasan struktural atau terciptanya keadilan sosial sehingga terbentuklah suasana yang harmoni (Dep. Pen: 2008). Konsep "Irene" mengenai damai (perdamaian) memiliki arti rukun (harmoni). Sama dengan itu istilah Arab Salam dan bahasa Ibrani Shalom, yang artinya tidak adanya perang akan tetapi berarti kehidupan yang baik (wellbeing), menyeluruh (wholeness), rukun antara individu, masyarakat dan antar bangsa.

Salam dan Shalom juga bermakna cinta (love) kesehatan yang penuh (full health), kesejahteraan (prosperity), pemerataan kebutuhan (redistribution of good), dan rekonsiliasi. Ada istilah Sansekerta "Shanti ysng berarti kedamaian pikiran, kedamaian di bumi, kedamaian di kedalaman lautan, kedamaian di luar angkasa. Konsep shanty ialah bermakna kedamaian semesta. Istilah cina "ping" berarti rukun, mengupayakan kesatuan dalam keragaman.

\section{Nilai persamaan dan keadilan (Al-Musawah dan Al-'Adl)}

Kyai membiasakan menilai persamaan dan keadilan dilingkungan pesantren merujuk pada Al-Qur'an surah AlMaidah: 8. Semua santri dipesantren haknya sama yaitu mendapatkan pendidikan dan pelayanan yang sama tanpa memandang asal usul daerah santri dan sosial konominya. Istilah Al-Musawah adalah kesejajaran, artinya tidak ada pihak yang merasa lebih tinggi dari yang lain sehingga tidak dapat memaksakan kehendaknya terhadap orang lain. Kyai dalam pesantrenpun tidak bisa memaksakan kehendaknya terhadap santri yang dipimpin, berlaku otoriter dan eksploitatif. Kesejajaran seperti ini penting dalam lingkungan pesantren demi menghindari hegemoni dalam pesantren.

Dalam perspektif Islam, Pemimpin ialah orang atau Kyai atau institusi yang diberi wewenang dan kepercayaan oleh yang dipimpin untuk melaksanakan dan menegakkan 
peraturan yang telah dibuat. Oleh sebab itu pemimpin memiliki tanggung jawab besar di hadapan orang yang dipimpin, demikian juga kepada Tuhan. Dengan begitu pemimpin harus amanah, memiliki sikap dan perilaku yang dapat dipercaya, jujur dan adil.

Diantara sebagian ulama' memahami, bahwa almusawah sebagai konsekuensi logis dari prinsip alsyura dan al-'adalah. Diantara dalil al-Qur'an yang sering digunakan dalam hal ini adalah surat al-Hujurat:13, sementara dalil sunnah-nya cukup banyak antara lain tercakup dalam khutbah wada' dan sabda Nabi kepada keluarga Bani Hasyim. Nabi pernah berpesan kepada keluarga Bani Hasyim sebagaimana sabdanya: Wahai Bani Hasyim, jangan sampai orang lain datang kepadaku membawa prestasi amal, sementara kalian datang hanya membawa pertalian nasab. Kemuliaan di sisi Allah adalah ditentukan oleh kualitas takwanya.

4. Nilai Toleransi (At-Samuh)

Kata Tasamuh berasal dari bahasa Arab yang berarti murah hati atau lapang hati. Dalam Kamus Besar Bahasa Indonesia (KBBI), tasamuh artinya kelapangan dada, keluasan pikiran, dan toleransi. Maksud dari tasamuh adalah bersikap menerima dan damai terhadap keadaan yang dihadapi, misalnya toleransi dalam agama ialah sikap saling menghormati hak dan kewajiban antaragama. Para santri dianjurkan untuk saling menghargai perbedaan yang terdapat pada setiap santri yang ada dipesantren, seperti: Minat, kepribadian, asal usul daerah, kecerdasan dan status soial ekonomi para santri.

5. Persaudaraan dan kebersamaan (Asukhuwwah)

Persaudaraan dan kebersamaan dipesantren diantaranya: para santri meyakini sama-sama orang Islam, para santri merasa sama-sama jauh dari keluarga dan mereka mempelajari ilmu Agama Islam tujuan yang sama. 


\section{Musyawarah (Al-Musyawwarah)}

Musyawarah dijadikan metode untuk mengkaji kitabkitab klasik bagi para santri senior untuk membahas persoalan keagamaa. Dalam Kamus Besar Bahasa Indonesia, musyawarah diartikan sebagai: pembahasan bersama dengan maksud mencapai keputusan atas penyelesaian masalah bersama. Selain itu dipakai juga kata musyawarah yang berarti berunding dan berembuk (Dep.Pend dan Kebu: 1989).

Pesantren bisa mengintegrasikan nilai-nilai multikultural sesuai dengan konsep-konsep diatas. Hal tersebut bisa diterapkan dalam sehari-hari di kehidupan lingkungan pesantren pasca pandemi. Dengan diterapkan integrasiintegrasi pesantren diharapkan mencetak generasi-generasi yang humaisme

\section{Daftar Pustaka}

Aly, Abdullah. 2008. Pendidikan Islam multikultural di pesantren: telaah terhadap kurikulum pondok pesantren modern Islam Assalam Surakarta Tahun 2006/2007.

Departemen Pendidikan dan Kebudayaan, Kamus Besar Bahasa Indonesia (Jakarta: Balai Pustaka, 1989), 603

Iahsolikhah,Ta'awun dan Israf, 2011, (Online),Tersedia https://iahsolikhah.wordpress. com tawun-dan-israf/. (05 Januari 2019)

Kementerian Pendidikan Dan Kebudayaan. accessed Mei 01, 2021, https://www.kemdikbud.go.id/main/blog/2020/03/si kapi-covid19-kemendikbud-terbitkan-dua-suratedaran.

Madjid, Nurcholish. 1997. Masyarakat Religius. Jakarta: PARAMADINA 
Mastuhu. 1994. Dinamika Sistem Pendidikan Pesantren. Jakarta: INIS.

Nasruddin, Rindam, and Islamul Haq. (2020). "Pembatasan sosial berskala besar (PSBB) dan masyarakat berpenghasilan rendah." SALAM: Jurnal Sosial dan Budaya Syar-i 7.7: 639-648.

Siti Afiah, Tolong Menolong Dalam Islam, 2015, (Online), Tersedia:http://gardapena.blogspot.co.id/2015/09/tol ong-menolong-dalam-islam.html. (17 Januari 2019)

Siyono, "Nyalakan Semangat Pendidikan Melalui Daring'. Buku Bunga Rampai Pendidikan, Tulungagung: Akademia Pustaka

UNICEF. (2020). COVID-19 dan Anak-Anak di Indonesia Agenda Tindakan untuk Mengatasi Tantangan Sosial Ekonomi. In Journal of education, pshycology and counseling(Vol. 2). Retrieved from www.unicef.org ${ }_{2}$

Wajdi, Muh Barid Nizarudin, et al. (2020)."Pendampingan Redesign Pembelajaran Masa Pandemi Covid-19 bagi Tenaga Pendidik di Lembaga Pendidikan berbasis Pesantren di Jawa Timur." Engagement: Jurnal Pengabdian Kepada Masyarakat 4.1: 266-277.

Winanti, S. Poppy dan Hariyanto,.Titok. 2004. Demokrasi dan Civil Society. Yogyakarta: IRE Press.

Zamroni. 2001. Pendidikan Demokrasi Pada Masyarakat Multikultur. Yogyakarta: Bigraf Publishing 


\section{KONSEP PENGEMBANGAN "GURU MERDEKA BELAJAR" DI DALAM IMPLEMENTASI PEMBELAJARAN TATAP MUKA TERBATAS}

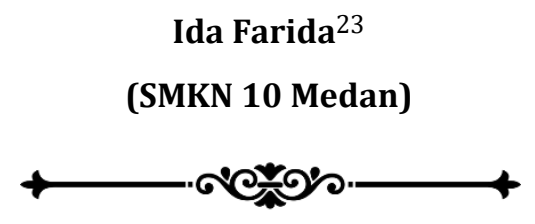

"Konsep Guru merdeka belajar selalu berefleksi untuk menyesuaikan hasil perbuatannya atau penyesuaian dalam pemikiran terhadap upaya dalam perubahan mencapai tujuan yang di inginkan"

\section{A. Merdeka Belajar}

Kata merdeka adalah mendiskripsikan pergerakan KSemangat usaha yang dekat dengan kita sebagai kata penyemangat. Di tahun 1952 Ki Hajar Dewantara mencetuskan suatu kata Merdeka dalam Pendidikan bukanlah hal baru bahwa di semangat merdeka yang tertuang di buku Peringatan Taman Siswa ke 30 Tahun berbunyi "kemerdekaan hendaknya dikenakan terhadap caranya anakanak berpikir, yaitu jangan selalu "dipelopori", atau disuruh mengakui butir pikiran orang lain"

Merdeka Belajar merupakan program kebijakan baru Kementerian Pendidikan dan Kebudayaan Republik Indonesia (Kemendikbud RI) yang dicanangkan oleh Menteri

\footnotetext{
${ }^{23}$ Penulis lahir di Palembang, 16 Oktober 1969, penulis merupakan Guru di SMK Negeri 10 Medan bidang Kecantikan, penulis menyelesaikan gelar Sarjana Tata Busana di Universitas Negeri Medan (1994), sedangkan gelar Magister Managemen diselesaikan di Universitas Harapan Medan (2012).
} 
Pendidikan dan kebudayaan Nadiem Anwar Makarim. Beliau membuat kebijakan merdeka belajar bukan tanpa alasan. Didalam merdeka belajar terdapat tiga komponen antara lain: 1) komitmen terhadap tujuan, 2) menetukan pilihan cara, 3) serta melakukan refleksi. Memilih sebagai seorang Pengajar berarti selalu memberdayakan murid secara optimal, mengupayakan cita-cita dan mengupayakan untuk terus memperbaiki diri, Untuk Membuat siswa merdeka belajar dan menciptakan Pendidikan yang merdeka belajar, pastilah membutuhkan seorang pengajar merdeka belajar. Pengembangan guru sangat di perlukan dalam pembelajarn meskipun terkadang anggaran yang di keluarkan oleh pihak Lembaga ataupun isntitusi tersebut sangat kecil.

\section{Guru Merdeka Belajar}

Perangkat yang penting di kuasai sang pengajar untuk terampil mengajar ialah diri sendiri, bukanlah penemuan pembelajaran, media pembelajaran, taktik pembelajaran karena hal tersebut bukanlah modal utama untuk guru dalam mengajar, Didalam kelas ketika belajar dan bertatap muka yang di perhatikan pertama kali ialah sosok gurunya,siapa gurunya,seperti apa gurunya, Hal ini akan selalu di ingat oleh siswa ketika mengingat gurunya sewaktu di sekolah dulu, Karena siswa akan mengingat bagaimana gurunya dulu memperlakukan siswa nya di dalam kelas. Berdasarkan pernyataan di atas Maka Seorang guru harus memahami "Merdeka Belajar ', mengapa...? Karena Ketika gurunya sudah merdeka belajar maka itu akan menjadi modal penting untuk mempengaruhi, mendidik dan mengajar para siswa. Seorang guru jika sudah merdeka belajar, semangat belajar, memiliki rasa ingin tau, tidak mudah mengeluh terhadap kesulitan, dan guru reflektif meminta umpan balik siswa untuk melakukan perbaikan, mau mendengarkan serta mau melakukan koreksi, hal diatas merupakan proses pengajaran yang seharusnya ada dalam diri guru agar siswa yang di didik di kelas akan mengikuti semangat merdeka belajar. Jadi itu pentingny mengapa semua guru wajib memahami merdeka belajar, 
bukan hanya saja memahami tetapi juga mempraktekkan bagaimana merdeka belajar tersebut.

Profesi sebagai guru karena ingin membuat perubahan, seseorang guru bekerja sampai malam, guru sudah mengetahui sejak awal bahwa menjadi guru bukanlah profesi yang banyak menghasilkan uang, tetapi tetap memilih untuk menjadi guru.Memilih menjadi guru adalah upaya untuk mewujudkan cita- cita.

\section{Konsep Guru Merdeka Belajar}

Konsep Guru merdeka belajar merupakan implementasi dari guru yang selalu berefleksi untuk menyesuaikan hasil perbuatannya atau penyesuaian dalam pemikiran terhadap upaya dalam perubahan mencapai tujuan yang di inginkan. Didalam proses pengajaran seseorang guru harus memiliki komitmen pada tujuan apa yang akan di tuju, antara lain ;

1. Dalam pembelajaran guru harus memahami dan memperiotaskan murid sebagai subjek di dalam kelas.

2. Untuk mencapai dalam pembelajaran dan pengembangan diri, guru harus menetapkan tujuan dan target yang menantang akan tetapi harus realitis nyata dalam pembelajaran.

3. Guru harus sadar betul atau utuh dalam melakukan praktik pembelajaran yang esensial.

Seorang guru dikatakan "Guru yang merdeka belajar “ harus mandiri dalam konsep pengembangan belajar dengan cara:

1. Guru mampu melakukan pengembangan diri dengan mengikuti kegiatan ( berbagi, pelatihan,coaching, berkomunitas dll).

2. Guru mampu melakukanmembuat atau merancang media pembelajarandengan berdasarkan apa yang dibutuhkan oleh murid. 
3. Guru mampu mengatasi kesulitan dengan mencari cara bagaimana jalan keluar mengatasi kesulitanyang di dapatkan pada pembelajaran murid.

Selain proses diatas, konsep guru merdeka belajar lainnya yaitu seseoarng guru tersebut harus mampu melakukan "Refleksi secara Berkala" dengan membuat tahapan, antara lain:

1. Untuk memperbaiki pembelajaran, Seoarang guru harus meminta umpan balik dari rekan kerja maupun pimpinan unit dimana guru tersebut bekerja.

2. Pada rencana pembelajaran dan pengembangan diri dalam proses mengajar guru dapat menindaklanjuti hasil refleksi dan umpan balik tersebut.

3. Dalam proses pembelajaran untuk mengetahui dan mengenal apa yang sudah efektif dan apa yang harus di perbaiki.

\section{Empat Kunci Pengembangan Guru Merdeka Belajar}

Guru yang memiliki kemerdakaan adalah guru yang mandiri, tidak mudah menyerah menghadapi tantangan dan tidak cepat menyalahkan orang lain atau keadaan, Guru yang memiliki kemerdakaan adalah guru yang reflektif secara aktif mencari umpan balik dan juga bisa menilai diri sendiri dengan objektif. Disini akan dijelaskan Empat kunci pengembangan diri didalam guru antara lain ;

1. Kemerdekaan

Dalam menentukan cara, tujuan dan refleksi serta belajar, Guru merdeka belajar memiliki kesempatan untuk melakukan secara terus menerus dalam pengembangan diri, missal guru memilih pelatihan yang sesuai kebutuhan dalam belajarnya dan dapat menentukan target atau tujuan kinerja di lingkungan sekolah, serta guru merdeka belajar dapat melakukan refleksi secara berkala terhadap apa yang sudah di capai dan dalam proses pencapaian terget tersebut. 
2. Kompetensi,

Guru yang berkompeten bukan hanya sekedar pengetahuan atau bisa mengajar diatas kertas ujian, tetapi guru yang bisa melakukan aksi yang beragam didalam kelas dan juga terus melakukan inovasi, Guru yang kompeten adalah guru yang professional, Profesional dalam arti adaktif bisa menyesuaikan diri di beragam situasi. Kompetensi bukan pernyataan diri sendiri, kompetensi harus bisa di tunjukkan, Dimana kepada siswa yang bagaimana dan dalam hal mengajarkan apa, Guru yang kompeten sadar betul bahwa guru tidak bisa berkompeten sendirian, Bahwa apa yang dimiliki setiap individu sebenarnya adalah kompetensi yang akan berbuah kompetensi hanya bila ada ekosistem yang mendukung tumbuhnya kompetensi

3. Berkolaborasi

Pengalaman bekerja dan belajar dengan rekan sejawat adalah pengalaman yang tidak akan ternilai dan sering kali lebih penting daripada belajar dengan ahli, Kolaborasi dengan sesame guru adalah kesempatan dengan mudah dalam percakapan dan kehidupan sebagai guru sehari-hari, Pengalaman berkolaborasi dengan sesame guru yang terjadi di tubuh pendidik terjadi di antara guru bidang studi antara guru didalam pendiidkan bahkan didalam instruktur institusi formal maupun non formal.

4. Berkarir

Selama ini karir dalam profesi sebagai guru sangat terbatas, satu satunya jalan karir yang tersedia berlimpah adalah kepala sekolah, hal itu pun tidak terbuka untuk semua guru. Seoarng guru bisa terus berkarir sebagai guru tapi juga mengembangkan karir guru dalam berbagai bidang yang beragam. Guru bisa berlatih utnuk menjadi pelatih bagi guru lain, Guru bisa menulis berbagai referensi, guru bisa menjadi pembuat berbagai 
materi yang kemudian di gunakan oleh komunita komunitas yang lebih luas. Untuk mengembangkan karir tidak hanya dibatasi oleh masa jabatan, Guru dengan berbagai jalur terus untuk belajar dan mengembangkan dirinya sepanjang hayat.

\section{B. Implementasi Merdeka Belajar Dalam Pembelajaran Tatap Muka Terbatas (PTMT).}

Adapun aspek-aspek dan peluang yang perlu diperhatikan dalam persiapan PTMT diantaranya; Pertama, meningkatkan capaian hasil belajar siswa. PTM terbatas harus disiapkan secara matang untuk mengatasi kelemahankelemahan Pembelajaran Jarak Jauh (PJJ). Dalam waktu yang terbatas di kelas, 2 sampai 3 jam, dan hanya 2 sampai 3 hari di sekolah, guru harus memanfaatkan waktu sebaik mungkin. Selain belajar di sekolah, siswa tetap melaksanakan pembelajaran daring.

Dalam pembelajaran tatap muka terbatas (PTMT) ini, pertama seorang guru perlu menerapkan dan mengembangkan suatu inovasi dalam pembelajaran, seperti model- model pembelajaran yang terkini seperti akun media belajar atau classroom, blended learning dan pembelajaran secara daring, selain itu guru juga perlu mengoptimalkan gawai yang dimiliki murid untuk menciptakan pembelajaran inovatif, aktif dan mendalam. Kedua Didalam merdeka belajar merupakan budaya belajar, hal ini terungkap dari bagaimana pembelajaran yang berkualitas bagi murid dan guru jangan sampai tertinggal harus selalu mengikuti pelatihan ataupun eksperimen dengan metode pembelajaran yang telah terbukti efektivitas dalam memperbaiki praktik mengajar.

Kedua hal diatas tentang merdeka belajar dalam pembelajaran tatap muka terbatas pada dasarnya mengingatkan guru untuk selalu bersemangat, seperti semangat berinovasi dan semangat belajar secara berkelanjutan untuk mendapatkan murid yang yang siap mengahadapi masa depannya. 


\title{
STRATEGI GURU DALAM MENGHADAPI PEMBELAJARAN PASCA PANDEMI DI SEKOLAH DASAR
}

\author{
Sofia G. Un Lala ${ }^{24}$ \\ (Universitas Nusa Cendana)

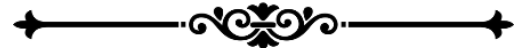

"Menyusun dan memilih strategi yang dapat dilakukan guru pasca pandemic covid 19 sangat penting untuk difikirkan. Amunisi yang baik sangat diperlukan, jangan sampai karena kalah strategi maka peperangan bukannya dimenangkan malah dikalahkan atau bahkan belum kalah pun sudah berhenti di tengah jalan menuju medan pertempuran"

Demenang dalam suatu peperangan akan mendapatkan hal
yang diinginkan sehingga perang itu terjadi. Wilayah,
kekuasaan, kekayaan, sumber daya alam dan manusia serta
aspek lain yang menyertainya. Menghadapi suatu peperangan
dibutuhkan kerjasama yang baik dari pimpinan, panglima
hingga para tantara. Kerja sama ini untuk menjalankan
strategi yang telah disusun dan disepakati sebelumnya secara
matang. Strategi ini tentunya berisi takti-taktik rahasia yang
tepat sasaran dan penuh perhitungan dalam perumusannya

${ }^{24}$ Penulis lahir di Kupang, 30 April 1992, penulis merupakan dosen Universitas Nusa Cendana di prodi PGSD FKIP. Penulis menyelesaikan gelar Sarjana Pendidikan di Universitas Nusa Cendana tahun 2014 dan memperoleh gelar Magister Pendidikan di Universitas Negeri Surabaya Tahun 2019 pada Program Studi Pendidikan Guru Sekolah Dasar 
sehingga ketetika strategi ini dijalankan dalam medan perang akan membawa kemenangan.

Ilustrasi di atas dianalogikan sebagai berikut: pemenang dalam peperangan adalah siswa dimana siswa akan mendapatkan pengetahuan, indikator pencapaian kompetensi akan tercapai, tujuan pembelajaran berjalan dengan baik dan hasil belajar tinggi. Peperangan adalah proses pembelajaran dimana dalam menghadapi pembelajaran diperlukan strategi yang tepat. Strategi ini dapat dirumuskan bersama oleh guru, bersama orang tua dan masyarakat.

Pandemi covid-19 yang tengah mengubah tatanan kehidupan sosial masyarakat menjadi faktor eksternal yang memengaruhi proses pembelajaran saat ini (Strielkowski, 2020). Tentunya dalam menghadapi pandemi covid 19 pemanfaatan teknologi pemanfaatan teknologi yang baik dalam penggunaan media pembelajaran dapat meningkatkan kualitas proses pembelajaran dan tentu akan berdampak pada hasil belajar (Setiaji \& Dinata, 2020). Namun penggunaan media pembelajaran yang memanfaatkan teknologi tidak lepas dari peran serta guru sebagai salah satu sumber pembelajaran. Peran guru dalam menyusun strategi untuk memenangkan peperangan tidak hanya dilihat dari pemanfaatan teknologi belaka namun bagaimana memanfaatkan teknologi itu untuk menginspirasi siswa belajar di masa pandemic covid 19 ini. Peran guru sangatlah penting mulai jadi sebagai motivator, inivator dan evaluator (Asriati, 2020). Sebagai motivator, guru selalu berusaha memberikan afirmasi positif pada siswa, memberikan kalimat-kalimat yang menenangkan siswa bahwa pandemi akan segera berakhir. Guru juga harus membangun hubungan yang baik dengan orang tua siswa dan masyarakat di lingkungan sekitar agar dapat mendunkung berjalannya proses pembelajaran selama pandemi. Sebagai innovator guru dituntut untuk menyesuakikan diri dengan pembelajaran masa pandemi yakni menguasai platform social media, whatssapp, google classroom, aplikasi-aplikasi video 
conference dan lain sebagainya yang dapat mendukung proses pembelajaran siswa. Sebagai evaluator guru wajib dapat mengevaluasi dan melihat kembals sejauh mana keberhasilan kegiatan pembelajaran yang diadakan, apa plus dan minusnya, bagaimana strategi untuk mengatasinya?

Ketika pandemic covid 19 mulai mereda dan pemerintah mulai untuk menggalakkan apa yang disebut New Normal yakni beraktifitas kembali dengan tetap memperhatikan protocol kesehatan yang berlaku, senjata yang dipersiapkan guru yakni motivasi, inovasi dan evaluasi merupakan sebagai strategi yang telah dikuasai sebelumnya. Sehingga guru dapat menarik benang merah seperti apa pembelajaran yang akan dilaksanakan pasca pandemi covid 19 ketika siswa diminta melaksanakan tatap muka kembali di sekolah. Pasca pademi strategi-strategi yang harus dikuasai oleh guru adalah sebagai berikut:

\section{Flashback}

Guru wajib meninjau kembali seperti apa proses pembelajaran yang dilakukan ketika pandemi covid 19. Guru perlu merefleksikan Kembali pertanyaanpertanyaan ini.

Apakah pembelajaran yang dilakukan selama masa pandemic efektif? Pertanyaan ini dapat dijawab dengan melihat pada hsail belajar siswa.

Apakah siswa di kelas rendah lancar membaca? Pertanyaan mendasar bagi siswa kelas rendah sebab siswa kelas rendah banyak yang belum dapat membaca dengan lancar. Jika siswa belum dapat membaca guru daoat bekerja sama dengan orang tua untuk meminta perhatian khusus orang tua.

2. Apakakah materi-materi prasaarat sudah dikuasi dengan baik?

Guru wajib melakukan peninjauan kembali atau melakukan pra-test untuk mengukur sejauh mana 
kemampuan awal siswa. Jika siswa di kelas 3, coba lakukan tes sederhana untuk mengukur sejauh mana pemahaman siswa untuk materi kelas 1 dan 2. Bukan untuk meragukan hasil belajar sebelumnya namun guru kelas wajib mangetahui sejauh mana kemapuan prasyarat siswa yang dikuasai. Jika materi belum dikuasai sekali lagi guru perlu memebri perhatian khusus pada siswa dengan bekerjasama dengan orang tua. Jika materi prasyarat belum dikuasai siswa akan sulit memahami materi selutnya di kelas yang lebih tinggi.

3. Evaluasi kembali proses pembelajaran kemarin

Mengevaluasi pembelajaran yang telah guru lakukan sebelumnya, apakah sisw sudah Kembali terbiasa dengan pembelajaran tatap muka di kelas? Ataukah siswa merasa kesulitan. Jika siswa merasa kesulitan guru dapat mengubah model pembelajaran dengan model pembelajaran lain yang lebih menarik tidak lupa dengan menyisipkan keterampilan 4C (Critical and Creative thinking, collaboration, Communication) dan keterampilan pemecahan masalah atau study case dan model pembelajaran lain yang menarik siswa.

4. Menentukan prioritas tujuan

Guru perlu menetapkan prioritas tujuan pembelajaran yang dicapai. Apakah pembelajaran pasca pandemi ini siswa perlu kembali dengan ritme belajar sebelum pandemic, masa pandemic atau kombinasi keduanya? Hal ini tentu berdasarkan karakteristik sisiwa di sekolah guru masing-masing. Bagaimana ketercapaian tujuan pembelajaran dalam setiap pertemuan?

\section{Blanded learning}

Blanded learning merupakan salah satu solusi dalam melaksanakan pembelajaran pasca pandemic covid 19 dengan membaurkan antara pembelajaran tatap muka dengan pembelajaran secara daring. 
6. Menciptakan suasana belajar yang menyenangkan

Suasana belajar sebelum pandemi covid 19, selama pandemic covid 19 dan pasca pandemic tentu bereda. Hal ini menjadi perhatian khusus bagi guru untuk menciptakan suasana belajar yang nyaman bagi siswa yang dalam masa transisi antara pembelajaran masa pandemic dan pasca pandemi. Media yang menarik, sarana dan prasarana pendukung, penggunaan model pembelajaran yang sesuai dan gestur guru yang nyaman sangat mempengaruhi suasana pembelajaraan pasca pandemic.

7. Perhatikan prokes

Guru perlu secara jeli menetapkan perhatian pada protokol Kesehatan selama pembelajaran, Riwayat vaksin siswa dan orang tua siswa serta selalu mengingatkan siswa pada pentingnya menjaga protokol Kesehatan meskipun sudah Kembali ke sekolah

8. Tetap berinovasi

Guru wajib untuk tetap berinovasi dengan semua proses pembelajaran yang ada saat ini, walaupun pandemic sudah mulai reda namun guru masih tetap harus berinovasi dengan tetap belajar menggunakan patform pembelajaran online dan mengikuti webminar ataupun seminar - seminar yang ada. Guru harus tetap memiliki kemauan untuk belajar terutama untuk mendukung jalanya pembelajaran pasca pandemic.

9. Evaluasi

Tetap melakukan evaluasi terhadap setiap pembelajaran yang dilakukan. Mintalah siswa untuk memberikan upan balik seperti apa pembelajaran yang mereka sukai untuk esok hari agar guru dapat merancang pembelajaran yang 
dapat membuat siswa menyesuaikan diri dalam proses pembelajaran saat ini.

Demikian strategi yang dapat dilakukan guru pasca pandemic covid 19 untuk memenangkan peperangan. Amunisi yang baik sangat diperlukan, jangan sampai karena kalah strategi maka peperangan bukannya dimenangkan malah dikalahkan atau bahkan belum kalah pun sudah berhenti di tengah jalan menuju medan pertempuran.

\section{Daftar Pustaka}

Astriadi. 2021. Fungsi dan peran guru di tengah pandemic covid 19 dalam menginspirasi siswa belajar secara daring.

[Online]. https://ayoguruberbagi.kemdikbud.go.id/artikel/

Setiaji, B., Dinata, P. A. C. 2020. Analisis kesiapan mahasiswa jurusan pendidikan fisika menggunakan e-learning dalam situasi pandemi Covid-19. Jurnal Inovasi Pendidikan IPA 6(1), 59-70. Doi: 10.21831/jipi.v6i1.31562

Strielkowski, W. 2020. COVID-19 pandemic and the digital revolution in academia and higher education. Preprints, 1-6. Doi: 10.20944/preprints202004.0290.v1 


\section{BAB III}

\section{LITERASI FISIK PENDIDIKAN JASMANI DAN}

OLAHRAGA

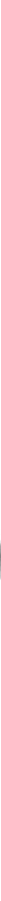




\title{
PEMBELAJARAN BLENDED LEARNING PADA MATA KULIAH PENJASKES DI IAIN MADURA
}

\author{
Mutik Nur Fadhilah, M.Pd. ${ }^{25}$ \\ (IAIN Madura)

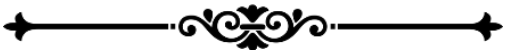

"Mata kuliah penjaskes pada mahasiswa Prodi PGMI terdiri dari dua aspek, aspek teori dan praktek. Dengan adanya proses pembelajaran blended learning calon guru MI/SD mampu memahami antara pengetahuan dan tata cara pelaksanaanya"

Droses pembelajaran di era new normal pasca pandemi
mengalami perubahan yang siginifikan. Hal ini terjadi pada perkuliahan TMT (Tatap Muka Terbatas), dengan menggunakan jumlah keseluruhan mahasiswa yang masuk sebesar 50\%. Perubahan ini digunakan untuk menjaga satu sama lain dari bahaya adanya transmisi virus covid-19 (Pragholapati, 2020). Untuk itulah, proses pembelajaran tatap muka dilakukan secara bertahap sesuai kebijakan pemerintah daerah.

Begitu pun di IAIN Madura, proses pembelajaran dilaksanakan secara blended learning (Fadhilah, 2021). Dalam satu kelas mata kuliah penjaskes dibagi menjadi dua sesi, sesi luring dan sesi daring menggunakan aplikasi e-

${ }^{25}$ Penulis lahir di Malang, 29 Mei 1992, penulis merupakan Dosen IAIN Madura dalam bidang PGMI, penulis menyelesaikan gelar Sarjana PGMI di Universitas Islam Negeri Maulana Malik Ibrahim Malang (2015), sedangkan gelar Magister PGMI diselesaikan di Universitas Islam Negeri Maulana Malik Ibrahim Malang (2017). 
learning atau grup WA sebagai monitoring dalam proses pembelajaran (Hanifah Salsabila et al., 2020). Bagi mahasiswa yang mendapat jadwal luring maka harus menggunakan masker dan menerapkan protokol kesehatan.

Protokol kesehatan merupakan salah satu hal yang harus ditaati oleh semua anggota masyarakat dalam menunjang kehidupan di era new normal atau pasca pandemi ini (Widiyono, 2020). Lebih baik mencegah daripada mengobati, dengan menjaga satu sama lain akan menjadikan kehidupan yang lebih nyaman. Serta meningkatkan kualitas kesehatan yang lebih baik.

Sekarang kita akan kembali membahas mengenai pembelajaran blended learning pada mata kuliah penjaskes di IAIN Madura khususnya Prodi PGMI. Proses pembelajaran yang dilakukan dalam satu waktu dan menggunakan luring dan daring sekaligus menuntut daya kreatifitas dan manajemen waktu yang dilakukan dosen kepada mahasiswa secara seimbang. Kedua proses pembelajaran tersebut harus dilakukan dalam satu waktu dan dilaksanakan sesuai RPS.

Blended learning merupakan sebuah proses pembelajaran yang terdiri dari dua perpaduan luring (tatap muka) atau daring (pembelajaran online/pembelajaran jarak jauh) (MN Fadhilah, 2020). Sehingga proses pembelajaran dilakukan sesuai dengan kebutuhan yang ada di kelas tersebut. Serta sesuai dengan kebijakan instansi pendidikan, pemerintahan dan keadaaan yang terjadi pada saat itu.

Keadaan yang sedang kita alami sekarang, merupakan sebuah proses perpindahan dari masa pandemi kepada keadaan yang baru atau normal seperti sedia kala. Sehingga memerlukan beberapa adaptasi baru terkait proses pembelajaran yang terjadi pada perguruan tinggi khususnya di IAIN Madura. Akan tetapi, IAIN Madura telah memberikan beberapa terobosan baru dalam proses pembelajaran yang dilaksanakan selama ini melalui aplikasi e-learning di IAIN Madura. 
Penjaskes merupakan sebuah pendidikan jasmani dan kesehatan dalam meningkatkan tumbuh kembang jasmani, kebugaran tubuh dan menjaga kesehatan. Hal tersebut merupakan sebuah holistik terhadap keseimbangan jasmani dan rohani (Husdarta, 2011: 3). Khususnya di era new normal yang memerlukan stamina yang kuat dalam menghadapi berbagai ancaman virus.

Mata kuliah penjaskes pada mahasiswa Prodi PGMI tentunya terdiri dari dua aspek, aspek teori dan praktek. Kedua hal ini merupakan salah satu cara dalam mengajarkan calon guru MI/SD memahami antara pengetahuan dan tata cara pelaksanaanya. Dengan adanya proses pembelajaran blended learning, maka setiap kelas dibagi menjadi 2 kelompok (kelompok yang belajar luring ataupun kelompok belajar daring).

Sehingga memungkin proses pembelajaran terjadi sesuai dengan mata kuliah yang disesuiakan dengan RPS. Mahasiswa yang mendapatkan jadwal kelas luring, maka akan langsung praktek materi yang masih berlangsung pada saat itu atau dapat mengulang atau memajukan materi sesuai dengan kesepakatan kelas tersebut. Kelas luring mampu mengikuti proses pembelajaran daring, karena materi sudah ada di $e$ learning dan hasil diskusi ada pada grup WA kelas (Suharyanto \& Mailangkay, 2016). Memudahkan para mahasiswa dalam proses pembelajaran yang semakin fleksibel, meskipun terkendala ruang dan waktu dalam proses pembelajaran.

Berbeda halnya mahasiswa yang mengikuti kelas daring akan fokus pada pengetahuan teori saja. Akan tetapi prakteknya akan dilakukan sama sesuai dengan pembagian yang telah ditentukan di kelas awal. Terjadi keseimbangan penggunaan proses pembelajaran blended learning pada masing-masing kelas sesuai dengan mata kuliah penjaskes. 


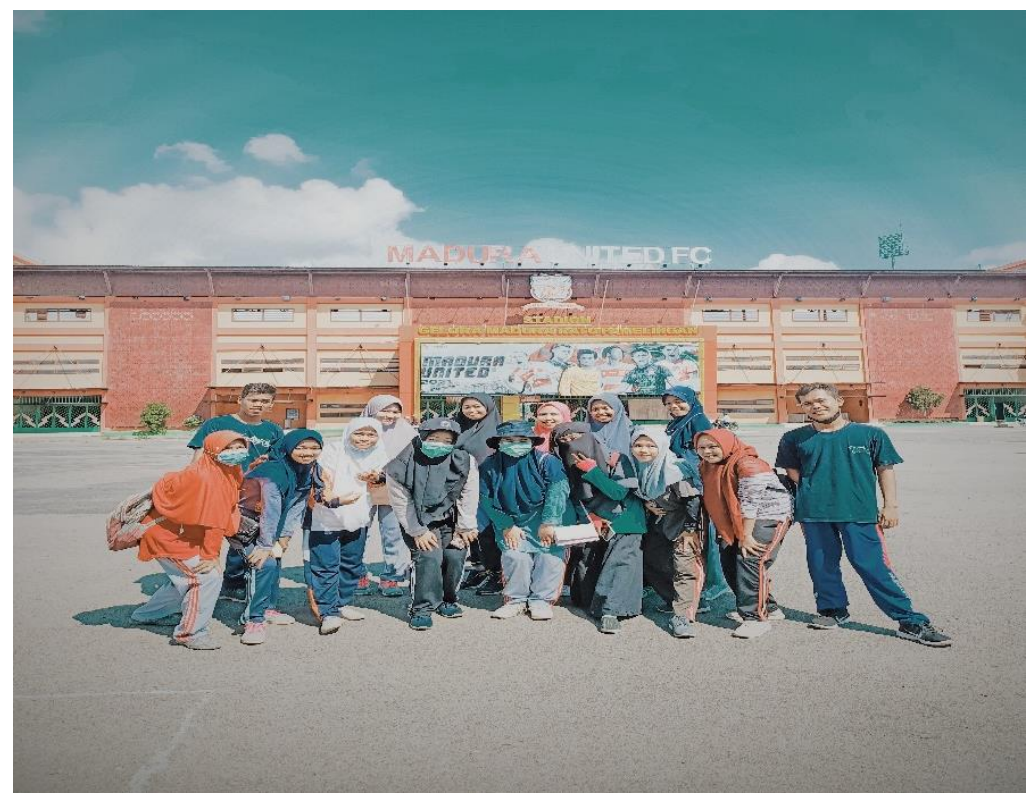

Gambar 1. Praktek Penjaskes

Berdasarkan gambar diatas, dapat diketakui dalam praktek penjaskes pada sesi pembelajaran blended learning secara luring. Proses pelaksanaannya 50\% dari jumlah mahasiswa dalam satu kelas, dilakukan di stadion gelora madura ratu pameling di Pamekasan. Agar mahasiswa tetap mampu menjaga kebugaran tubuhnya di masa new normal. Serta mengikuti proses perkuliahan sesuai kebijakan instansi pendidikan di IAIN Madura. Sehingga ke depan menjadi guru yang luas pengetahuannya dan mampu mengimplementasikan teori pembelajaran kepada peserta didiknya di jenjang SD/MI. 


\section{Daftar Pustaka}

Fadhilah, M. N. (2021). PERAN LITERASI DIGITAL DALAM MODEL PEMBELAJARAN BLENDED LEARNING MAHASISWA PGMI. Mubtadi, 3(1), 13-24. https://doi.org/https://doi.org/10.19105/mubtadi.v3i1. 4456

Hanifah Salsabila, U., Irna Sari, L., Haibati Lathif, K., Puji Lestari, A., \& Ayuning, A. (2020). Peran Teknologi Dalam Pembelajaran Di Masa Pandemi Covid-19. AlMutharahah: Jurnal Penelitian Dan Kajian Sosial Keagamaan, 17(2), 188-198. https://doi.org/10.46781/al-mutharahah.v17i2.138

Husdarta. 2011. Manajemen Pendidikan Jasmani. Bandung: Alfabeta.

MN Fadhilah. (2020). BLENDED LEARNING DALAM MENINGKATKAN KEMAMPUAN HOTS MAHASISWA PGMI STAIPANA Mutik. Jurnal Studi Islam: Pancawahana, 15(1), 111-122.

Pragholapati, A. (2020). New Normal "Indonesia” After Covid19 Pandemic. 2019, 1-6. https://doi.org/10.31234/osf.io/7snqb

Suharyanto, \& Mailangkay, adele B. L. (2016). Penerapan ELearning Sebagai Alat Bantu Mengajar Dalam Dunia Pendidikan. Jurnal Ilmiah Widya, 3, 17-21. https://doi.org/10.1016/j.neubiorev.2016.02.001

Widiyono, A. (2020). Efektifitas Perkuliahan Daring (Online) pada Mahasiswa PGSD di Saat Pandemi Covid 19. Jurnal Pendidikan, $8(2)$, 169-177. https://doi.org/10.36232/pendidikan.v8i2.458 


\title{
PERKULIAHAN TEORI DAN PRAKTEK PENCAK SILAT II PASCAPANDEMI
}

\author{
Dr. Agus Mukholid, M.Pd. ${ }^{26}$ \\ (Universitas Sebelas Maret Surakarta)

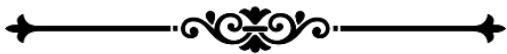

"Perkuliahan Teori dan Praktek Pencak Silat II dilaksanakan

dengan metode Blended Learning, di mana mahasiswa yang berdomisili pada eks karesidenan surakarta perkuliahan secara tatap muka, sedangkan yang berada di luar eks karesidenan, menggunakan zoom meeting yang dilaksanakan secara bersamaan"

Derkembangan pencak silat sekarang telah mengalami
perkembangan yang sangat pesat dan menjadikan kabar yang menggembirakan, salah satunya ditunjang beberapa genre film yang diangkat dalam layar lebar dan dunia perfilman. Akan tetapi jauh sebelum masuk proses perfilman tersebut ada tahapan belajar pencak silat yang sangat fundamental yaitu pembelajaran pencak silat melalui perguruan pencak silat maupun pembelajaran melalui dunia Pendidikan yang formal. Pembelajaran pencak silat dapat dilaksanakan sejak Sekolah Dasar atau sederajat hingga

\footnotetext{
${ }^{26}$ Penulis lahir di Boyolali, 31 Januari 1964, merupakan Dosen di Program Studi Pendidikan Jasmani, Kesehatan dan Rekreasi (PJKR), Fakultas Keolahragaan (FKOR) UNS Surakarta, penulis menyelesaikan gelar Sarjana di POK FKIP UNS (1988), menyelesaikan gelar Magister di Pascasarjana Prodi Pendidikan Olahraga IKIP Jakarta (1997), dan menyelesaikan gelar Doktor Prodi Ilmu Pendidikan Pascasarjana UNS Surakarta (2018).
} 
Sekolah Menengah Atas atau sederajat melalui kegiatan Ekstrakurikuler. Sedangkan pada jenjang perguruan tinggi, pencak silat dapat dipelajari melalui kegiatan Unit Kegiatan Mahasiswa (UKM) yang terdapat pada kampus masing masing, di mana mahasiswa dapat memilih sesuai minat masing-masing. Namun hal tersebut berbeda ketika pembelajaran pencak silat yang dilakukan pada Prodi Pendidikan Jasmani, Kesehatan dan Rekreasi (PJKR), dalam pembelajaran, seluruh mahasiswa diwajibkan tanpa kecuali untuk memilih dan mengikuti perkuliahan Teori dan Praktek Pencak Silat 1.

Perkuliahan Teori dan Praktek Pencak Silat I pada Prodi Program Studi Prodi Pendidikan Jasmani, Kesehatan dan Rekreasi (PJKR) Fakultas Keolahragaan Universitas Sebelas Maret memiliki bobot 2 SKS yang dilaksanakan pada semester Genap (Semester 4). Perkuliahan tersebut merupakan kuliah teori dan praktek yang mempelajari sejarah, peraturan, Teknik dasar, Rangkaian Teknik, hingga Jurus Baku. Sedangkan perkuliahan Teori dan Praktek Pencak Silat II dilaksanakan pada Semester Ganjil (Semester 5) dengan mempelajari Peraturan Pertandingan, Simulasi Praktek Peraturan Pertandingan Kategori Tanding dan Kategori Tunggal (Mahasiswa Menghafalkan Jurus Baku Tunggal).

Perkuliahan Teori dan Praktek Pencak Silat II tersebut pada masa Pandemi Covid-19 dilaksanakan dengan cara Daring atau Online memanfaatkan platform Zoom meeting yang disediakan oleh admin Prodi. Pembelajaran secara Daring tersebut berlangsung mulai pertemuan yang pertama hingga pertemuan kedelapan dengan pendekatan instruksi verbal dan Proyek berbasis individu (individual based project), pertemuan kedelapan tersebut berbarengan dengan Ujian Tengah Semester (UTS). Pada pertemuan setelah UTS perkuliahan dilaksanakan dengan metode Blanded Learning, sebab pada masa tersebut sudah berlaku Pertemuan Tatap Muka Terbatas (PTMT). 
Pelaksanaan perkuliahan Teori dan Praktek Pencak Silat II setelah UTS dengan Blanded Learning. Blanded learning ini pada prinsipnya adalah pembelajaran yang menggunakan lebih dari satu metode, dan hal ini merupakan pilihan metode pembelajaran yang tepat saat PTMT. Tata cara Blended Learning pada perkuliahan Teori dan Praktek Pencak Silat II dilaksanakan dengan cara mahasiswa yang berdomisili di daerah Solo dan sekitarnya (eks karesidenan surakarta) perkuliahan secara tatap muka (off line) di kampus, sedangkan mahasiswa yang berada di luar eks karesidenan surakarta, menggunakan zoom meeting yang dilaksanakan secara bersamaan.

Kendala utama saat online, materi tidak bisa tersampaikan secara optimal kepada mahasiswa (Prayuda, 2021: 189). Secara umum perkuliahan yang dilaksanakan secara daring menyebabkan mahasiswa kurang berkembang pemikiran secara analitis studi kasus (Rahim, 2021: 30). Kurang optimal tersebut dikarenakan perkuliahan Teori dan Praktek Pencak Silat II yang bersifat praktek gerak (psikomotorik), yaitu Praktek Pelaksanaan Pertandingan Kategori Tanding dan Praktek Jurus Baku Tunggal. Perkuliahan yang bersifat praktek menuntut dosen pengampu untuk mendampingi satu persatu mahasiswa untuk menerima informasi, mempraktekkan serta memberikan umpan balik walaupun tidak ada permasalahan, akan tetapi jika ada permasalahan maka wajib bagi dosen pengampu untuk memberikan umpan balik baik umpan balik instant (langsung), delay (ditunda), maupun summary (ringkasan).

Perkuliahan selama PTMT ini sudah memanfaatkan alat bantu juga seperti penggunaan media Youtube. Pemberian materi yang dilakukan oleh dosen akan direkam dan diunggah pada channel Youtube sehingga setengah jumlah mahasiswa dapat menerima materi tersebut khususnya yang berada di luar karesidenan Surakarta. Dalam menerima informasi pembelajaran gerak pencak silat melalui media youtube tersebut tidak bisa dosen menkoreksi Gerakan yang ditirukan 
oleh mahasiswa dilakukan secara langsung dan saat itu juga. Koreksi gerak baru dapat dilaksanakan ketika mahasiswa daring memvidieo hasil Gerakan silatnya dan diunggah ke channel Youtube masing masing. Setelah vidieo berhasil diunggah maka mahasiswa yang bersangkutan mengirim link youtube tersebut kepada dosen pengampu. Ketika dosen pengampu menerima link tersebut maka barulah dosen yang bersangkutan dapat mengkoreksi gerakan pencak silat yang dipraktekkan oleh mahasiswa, apakah gerakan tersebut sudah benar atau masih ada kesalahan yang terjadi.

Umpan balik dan koreksi gerakan pencak silat melalui youtube tidak semudah mengkoreksi ketika mahasiswa melakukan gerakan langsung, hal ini dikarenakan pada youtube hanya menampilkan satu sisi sudut perekaman, sehingga dosen pengampu bisa jadi kurang detail dalam memberikan masukan tersebut. Terlebih dalam melakukan gerakan tertentu dengan kecepatan yang sangat tinggi harus ada pendampingan khusus oleh dosen agar mahasiswa tidak mengalami cedera yang diakibatkan oleh kesalahan gerakan maupun kesalahan tumpuan yang bisa mengalami terkilir, keseleo dislokasi bahkan yang parah adalah patah tulang.

Materi yang diberikan pada pertemuan kesembilan hingga kelima belas adalah Jurus Baku. Dalam perkuliahan yang berlangsung $2 \times 15$ menit tersebut mahasiswa dituntut mampu mempratikkan jurus baku dengan tiap pertemuan maksimal 2 jurus baku. Target Pengalaman Belajar yaitu mahasiswa dapat menunjukan sikap efektif serta kemampuan motorik. Selama perkuliahan luring pendekatan yang dilakukan oleh dosen pengampu dengan instruksi verbal dan praktik langsung di aula dengan tetap menerapkan protokol kesehatan yang selalu dianjurkan oleh pemerintah guna menjaga masing masing individu terhadap penularan covid-19. Sebetulnya sejak awal masuk luring semua mahasiswa diperbolehkan mengikuti perkuliahan ketika sudah melaksanakan vaksin dua kali dengan menunjukkan sertifikat vaksin kepada prodi. Perkuliahan luring dengan pelaksanaan praktik yang 
dilakukan bersamaan dalam Gedung disusun sedemikian dengan jarak antar mahasiswa tiga meter dengan harapan ada jarak untuk tetap menjaga kesehatan.

Semoga perkuliahan baik yang dilaksanakan secara Daring dan Luring bisa menjadikan mahasiswa tetap semangat dalam menimba ilmu dalam perkuliahan, demi tercapainya harapan dan cita-citanya. Dan semoga ilmu yang kita transformasi kepada peserta didik menjadikan ilmu yang bermanfaat dunia akhirat serta menjadi amalan jariyah yang dapat membatu kita di hari akhir nanti.

\section{Daftar Pustaka}

INTERNATIONAL PENCAK SILAT FEDERATION. 2013.

Peraturan Pertandingan Tahun 2012. Ver. 30-8-2013. Kuala Lumpur: PERSILAT

Prayudha, Joko. 2021. Students' Problems Face in Online Learning Amidt Pandemic Covid-19. Acitya: Journal of Teaching \& Education. Vol. 3 No. 22021.

Rahim, Mohammad Naim. 2021. Post-Pandemic of Covid-19 and the Need for Transforming Education 5.0 in Afghanistan Higher Education. Journal of Ultimate Research and Trends in Education. Vol. 3, No. 1, March 202 1, pp: 29 - 39. ISSN: 2685 - 4252 (Online) and ISSN: 2685 - 0540 (Print). 


\title{
PROGRAM LITERASI FISIK PADA MASA PEMBELAJARAN TATAP MUKA TERBATAS BAGI SISWA
}

\author{
Yudo Harvianto, S.Pd., M.Pd. ${ }^{27}$ \\ (Universitas Palangka Raya)

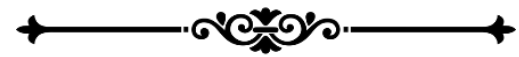

"Literasi fisik merupakan motivasi dan kepercayaan diri seseorang terhadap pemahaman dan kompetensi dalam aktivitas fisik, serta menghargai dan bertanggung jawab terhadap tubuhnya untuk melakukan aktivitas fisik seumur hidupnya"

12 November merupakan sebuah tanggal penting bagi dunia kesehatan negara kita. Sebab setiap tanggal 12 November selalu dijadikan sebagai peringatan Hari Kesehatan Nasional. Rutinitas tahunan berupa Hari Kesehatan Nasional atau disingkat HKN ini terus dilakukan, dengan mengambil tema yang sesuai kondisi kesehatan negara setiap tahunnya. Pada tahun 2021 ini, bertepatan dengan peringatan Hari Kesehatan Nasional ke-57 tema yang diusung oleh pemerintah yaitu "Sehat Negeriku, Tumbuh Indonesiaku". Salah satu alasan pemerintah mengusung tema ini

27 Penulis lahir di Pangkalan Bun, Kalimantan Tengah, 15 Januari 1991, penulis merupakan Dosen PJKR FKIP Universitas Palangka Raya dalam bidang Pendidikan Jasmani, Kesehatan dan Rekreasi, penulis menyelesaikan gelar Sarjana Pendidikan Jasmani, kesehatan dan Rekreasi di Universitas Palangka Raya (2013), sedangkan gelar Magister Pendidikan Olahraga diselesaikan di Universitas Negeri Surabaya (2015). 
dikarenakan Indonesia saat ini masih mengahadapi wabah pandemi covid-19. Dimana didalam beberapa data disebutkan sampai saat ini pandemi covid-19 telah merenggut nyawa kurang lebih 5 juta manusia di seluruh dunia. Sehingga melalui momentum Hari Kesehatan Nasional ini, diharapkan adanya kerjasama yang baik antara pemerintah dan masyarakat untuk semangat mengatasi pandemi covid-19 secara bersama-sama.

Salah satu bentuk implementasi dari tema dalam peringatan HKN ini yaitu memberikan edukasi kepada masyarakat sekolah terkhsusus kepada siswa tentang betapa pentingnya aktivitas fisik. Dengan edukasi yang diberikan kepada siswa, hendaknya siswa melek dan sadar tentang kebutuhan tubuh dalam melakukan aktivitas fisik. Edukasi yang diberikan kepada siswa bisa dengan berbagai macam cara salah satunya yaitu melalui program literasi fisik. Margaret Whitehead merupakan seorang tokoh yang pertama kali memperkenalkan isitlah (Physical Literacy).

The International Physical Literacy Association, (May 2014) mengatakan bahwa literasi fisik merupakan motivasi dan kepercayaan diri seseorang terhadap pemahaman dan kompetensi dalam aktivitas fisik, serta menghargai dan bertanggung jawab terhadap tubuhnya untuk melakukan aktivitas fisik seumur hidupnya. Rifki \& Welis (2013:1) berpendapat bahwa aktivitas fisik merupakan fungsi dasar utama dalam hidup manusia untuk memenuhi kebutuhan sehari-hari. Sedangkan Arovah (2012:5) mengatakan bahwa aktivitas fisik adalah gerak fisik yang dilakukan otot-otot tubuh dan sistem penunjangnya yang membutuhkan energi dalam melakukannya.

The International Physical Literacy Association (2014) mengatakan terdapat unsur-unsur literasi fisik diantaranya: 
1. Motivasi dan Keyakinan (Afektif)

Hal ini memiliki indikator seberapa antusiasme individu dalam menikmati aktivitas fisik yang dilakukan dan meyakini bahwa hal ini kebutuhan hidupnya.

2. Kompetensi Fisik (Fisik)

Indikator dari kompetensi fisik ini yaitu seberapa besar seseorang dapat melakukan dan mengembangkan keterampilan gerak yang dilakukan.

3. Pengetahuan dan Pemahaman (Kognitif)

Komponen mencakup seberapa besar kemampuan seseorang untuk mengidentifikasi dan memahami manfaat dari aktivitas fisik bagi kesehatan.

4. Keterlibatan dalam Aktivitas Fisik untuk Hidup (Perilaku)

Indikator dari komponen ini yaitu mengacu pada tanggung jawab dan kesadaran diri penuh yang dilakukan oleh seseorang dalam menyehatkan tubuhnya dengan beraktivitas fisik dikehidupan sehari-hari.

Salah satu program yang bisa dilakukan untuk mensukseskan unsur pengetahuan dan pemahaman (kognitif) yaitu dengan menggunakan media poster di sekolah. Hal ini sejalan dengan apa yang dikatakan oleh Sumartono \& Astuti (2018:8) yang mengatakan bahwa poster dapat dijadikan sebagai media komunikasi kesehatan. 
Berikut contoh-contoh poster program literasi fisik disekolah selama PTMT.
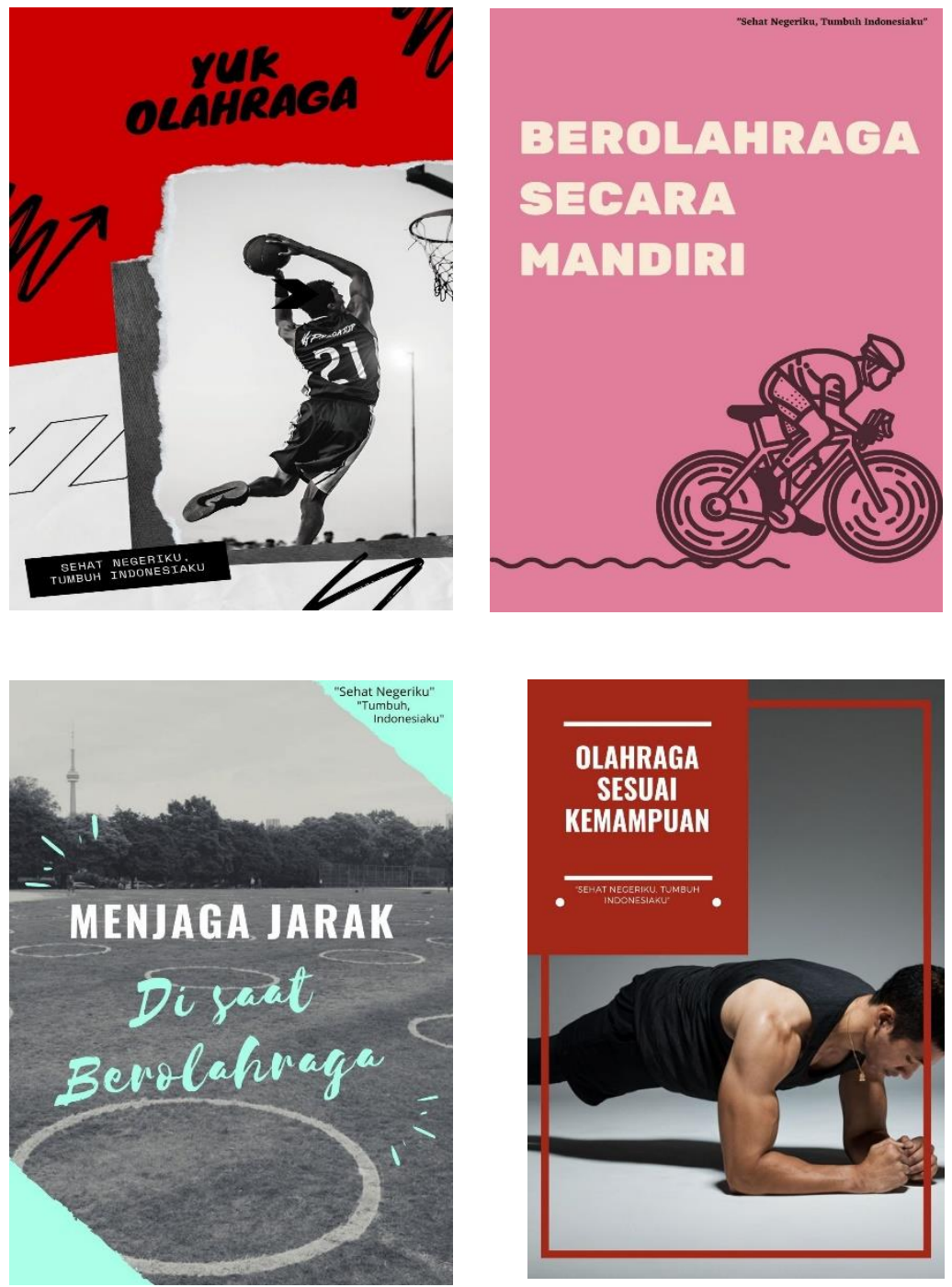


\section{Daftar Pustaka}

Arovah, Novita I. 2012. Status Kegemukan, Pola Makan, Tingkat Aktivitas Fisik dan Penyakit Degeneratif Dosen dan Karyawan Universitas Negeri Yogyakarta. MEDIKORA Vol. VIII, No 2. Doi. 10.21831/medikora.v0i2.4649

Sumartono. Astuti, Hani. 2018. Penggunaan Poster Sebagai Media Komunikasi Kesehatan. Komunikologi: Jurnal Ilmiah Ilmu Komunikasi Vol. 15 No 1.

Welis. Rifki, M. 2013. Buku Petunjuk Gizi untuk Aktivitas Fisik. Padang. Sukabina Press. 


\title{
PELAKSANAAN PEMBELAJARAN PJOK DENGAN MENGGUNAKAN HYBRID LEARNING DI SMA NEGERI 4 MALANG
}

\author{
Dony Andri Setiawan, M.Pd.28
}

(SMA Negeri 4 Malang)

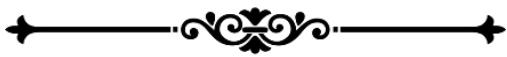

"Pelaksanaan Hybrid Learning dalam proses Pembelajaran Tatap Muka Terbatas lebih efektif dan efisien karena seluruh peserta didik secara bersamaan dapat mengikuti pembelajaran yang ada. Hybrid Learning dapat meningkatkan motivasi belajar peserta didik dan menumbuhkan kemampuan berfikir kritis pada diri peserta didik"

( 2 ong Life Education" sebuah ungkapan berbahasa Inggris hayat. Dengan kata lain, manusia dapat belajar kapan saja dan dimana saja. Pada era digital saat ini proses belajar berlangsung terus menerus dari waktu ke waktu tidak dibatasi ruang dan waktu. Era digital pada abad ini membawa dampak yang tidak dapat dipandang sebelah mata oleh dunia pendidikan khususnya di Indonesia. Implikasi globalisasi

${ }^{28}$ Penulis lahir di Ponorogo, 22 Agustus 1979, penulis merupakan Guru PJOK di SMA Negeri 4 Malang, penulis menyelesaikan gelar Sarjana Teknik Mesin di Universitas Jayabaya (2005), gelar Sarjana Pendidikan Jurusan Pendidikan Jasmani Kesehatan dan Rekreasi di IKIP Bbdi Utomo Malang (2008), sedangkan gelar Magister Pendidikan diselesaikan di IKIP Budi Utomo (2015), menjadi guru PJOK di SMA Negeri 4 Malang(2009). 
sangat berimbas pada bentuk pelayanan pendidikan yang diberikan oleh guru kepada peserta didik.

Tujuan Pendidikan Nasional yang tertuang dalam UU No. 20 Tahun 2003 adalah mengembangkan kemampuan dan membentuk watak serta peradaban bangsa yang bermartabat dalam rangka mencerdaskan kehidupan bangsa, bertujuan untuk berkembangnya potensi peserta didik agar menjadi manusia yang beriman dan bertaqwa kepada Tuhan Yang Maha Esa, berakhlak mulia, sehat, berilmu, cakap, kreatif, mandiri dan menjadi warga Negara yang demokratis serta bertanggungjawab dengan pengaturan panduan Pembelajaran Tatap Muka (PTM). Berdasarkan Surat Keputusan Bersama 4 Menteri mengeluarkan Keputusan untuk membuka sekolah harus mendapat persetujuan bukan hanya dari pemerintah daerah tetapi dari pihak sekolah, komite sekolah yang merupakan perwakilan para orang tua peserta didik. Sekolah tidak bisa memaksa peserta didik untuk datang ke sekolah. Sekolah di buka akan membuat kebijakan yang berbeda dari saat sebelum pandemic covid -19 jumlah peserta didik yang hadir dalam satu sesi kelas berdasarkan Level Pemberlakuan Pembatasan Kegiatan Masyarakat (PPKM)

Akibat dari dampak pandemi covid-19, Pemerintah telah mengambil kebijakan dalam pelaksanaan pendidikan formal. Menindaklanjuti Nota Dinas dari Dinas Pendidikan Provinsi Jawa Timur dan Instruksi Menteri Dalam Negeri Nomor 35 Tahun 2021 tentang Pemberlakuan Pembatasan Kegiatan Masyarakat Level 4, Level 3, dan Level 2 Corona Virus Disease 2019 di Wilayah Jawa dan Bali, dan hasil rapat koordinasi yang dipimpin oleh Menteri Koordinator Bidang Kemaritiman dan Investasi tanggal 26 Agustus 2021 maka Seluruh Kepala Cabang Dinas Pendidikan Wilayah se Jawa Timur agar melakukan koordinasi bersama para Kepala Sekolah SMA/SMK/SLB (Negeri dan Swasta) untuk melaksanakan Pembelajaran Tatap Muka Terbatas (PTMT). 
Pelaksanaan PTMT menyesuaikan dengan kondisi di sekolah masing-masing. Setiap sekolah akan menyiapkan beberapa hal untuk terlaksananya kegiatan PTMT, mulai dari ijin orang tua peserta didik, SOP protokol kesehatan sampai bagaimana guru harus mempersiapkan dan melaksanakan proses pembelajaran.

SMAN 4 Malang merupakan lembaga pendidikan dibawah Dinas Pendidikan Provinsi Jawa Timur yang terletak di Kota Malang, memiliki 27 rombongan belajar dengan jumlah peserta didik 901 orang. SMA Negeri 4 Malang telah melaksanakan Pembelajaran Tatap Muka Terbatas (PTMT) sejak tanggal 6 September 2021. Awal PTMT, sebanyak 35\% peserta didik dengan 18 rombongan belajar di sekolah secara langsung dan sisanya tetap belajar secara daring di rumah. Peserta didik yang belajar di sekolah tentunta atas ijin dan persetujuan orang tua/wali peserta didik. Direncanakan jumlah peserta didik yang hadir terus ditambah seiring turunnya level PPKM. SMA Negeri 4 Malang memberikan kebebasan metode dan model kepada guru dalam melaksanakan proses pembelajaran. Lebih dari $75 \%$ guru menggunakan cara hybrid learning dalam pelaksanaan pembelajaran.

Hybrid learning identik dengan blended learning. Hybrid learning adalah pembelajaran yang menggabungkan antara pembelajaran online dengan pembelajaran tatap muka secara teratur dan efektif (Boyle, dkk., 2003, Dowling, dkk., 2003, Vaughan, 2007, dan William, dkk., 2008). Graham \& Kaleta (2002) dan Barenfenger (2005) menyatakan bahwa hybrid learning adalah pembelajaran yang diintegrasikan secara normal melalui pembelajaran di luar kelas dimana dapat menggunakan fasilitas elektronik sebagai tutorial, kelompok belajar, atau informasi dari perpustakaan. Tsai (2011) menyatakan bahwa hybrid learning digunakan sebagai pembelajaran lingkungan melalui internet yang dipromosikan secara kelompok. Berdasarkan hal itu, hybrid learning adalah pembelajaran kolaborasi yang sangat efektif untuk diterapkan 
di dalam kelas (Singh, 2003). Pelaksanaan hybrid learning tergantung pada beberapa faktor, yaitu: (1) Sarana dan prasarana meliputi jaringan internet, (2) Pengembangan professional guru dalam mengakses TIK, (3) Peserta didik perlu dibekali pengetahuan untuk mengakses komputer dan internet dalam pelaksanaan hybrid learning. Selain itu, pelaksanaan hybrid learning harus disesuaikan dengan kondisi dan kebutuhan sekolah dan guru.

B. Jadwal Siswa yang melaksanakan PTM di sekolah periode 6 - 10 September 2021

\begin{tabular}{|c|c|c|c|c|c|}
\hline \multirow{2}{*}{ No } & \multirow{2}{*}{ Hari/Tanggal } & \multicolumn{3}{|c|}{ Kelas Yang Masuk } & \multirow{2}{*}{ Keterangan } \\
\hline & & Kelas X & Kelas XI & Kelas XII & \\
\hline \multirow{10}{*}{1} & \multirow{10}{*}{$\begin{array}{c}\text { Senin, } 6 \\
\text { September } \\
2021\end{array}$} & X Bhs No. Ganjil & XI Bhs No. Ganjil & DARING/ONLINE & \multirow{9}{*}{$\begin{array}{c}\text { Kelas X no } \\
\text { genap, XI no. } \\
\text { genap, dan } \\
\text { kelas XII } \\
\text { melaksanakan } \\
\text { pembelajaran } \\
\text { daring/online }\end{array}$} \\
\hline & & X MIPA 1 No. Ganjil & XI MIPA 1 No. Ganjil & DARING/ONLINE & \\
\hline & & X MIPA 2 No. Ganjil & XI MIPA 2 No. Ganjil & DARING/ONLINE & \\
\hline & & X MIPA 3 No. Ganjil & XI MIPA 3 No. Ganjil & DARING/ONLINE & \\
\hline & & X MIPA 4 No. Ganjil & XI MIPA 4 No. Ganjil & DARING/ONLINE & \\
\hline & & X MIPA 5 No. Ganjil & XI MIPA 5 No. Ganjil & DARING/ONLINE & \\
\hline & & X IPS 1 No. Ganjil & XI IPS 1 No. Ganjil & DARING/ONLINE & \\
\hline & & X IPS 2 No. Ganjil & XI IPS 2 No. Ganjil & DARING/ONLINE & \\
\hline & & X IPS 3 No. Ganjil & XI IPS 3 No. Ganjil & DARING/ONLINE & \\
\hline & & & $\begin{array}{c}\text { XI KBC No Ganjil dan } \\
\text { Genap }\end{array}$ & & \\
\hline
\end{tabular}

Melihat jadwal diatas, pembelajaran Tatap Muka Terbatas (PTMT) di SMA Negeri 4 Malang yang dimulai mulai tanggal 6 September 2021 dengan memasukkan peserta didik sejumlah $30 \%$. Mulai tanggal 1 November 2021 kebijakan pelaksanaan PTMT yang dilaksanakan di SMA Negeri 4 Malang menggunakan Hybrid Learning. Hal tersebut dilakukan karena $50 \%$ peserta didik melaksanakan tatap muka (PTM) di sekolah dan $50 \%$ belajar di rumah (BDR), sehingga pembelajaran dilaksanakan dengan menggunakan sistem Hybrid Learning. Dengan Hybrid Learning diharapkan seluruh peserta didik dalam satu kelas dapat mengikuti pembelajaran secara bersama. 
Pelajaran Pendidikan Jasmani Olahraga dan Kesehatan sangat relevan dengan proses pembelajaran Hybrid Learning. Seluruh peserta didik satu kelas dapat secara langsung mengikuti proses pembelajaran, sehingga tujuan pembelajaran PJOK bisa tercapai. Dalam kegiatan pembelajaran di lingkup sekolah, khususnya pada mata pelajaran PJOK menekankan pada aspek sikap, pengetahuan, dan keterampilan. Tentunya PJOK merupakan salah satu bagian penting dalam kurikulum 2013 untuk mencapai tujuan Pendidikan Nasional. Hasil penelitian oleh (Koc, 2017) menyatakan bahwa mata pelajaran PJOK memiliki tingkat efek positif dalam kegiatan pembelajaran disekolah yang sangat berpengaruh pada perkembangan peserta didik. Selain itu menurut (Wang, 2017) mengatakan bahwa PJOK memiliki pengaruh yang tidak tergantikan pada pembentukan karakter moral, perkembangan intelektual, estetika pencapaian dan gaya hidup sehat. Menurut (Ryan \& Poirier, 2012) menyimpulkan bahwa PJOK harus menjadi bagian yang signifikan dari kehidupan setiap orang dan lebih memahami pentingnya PJOK dalam kehidupan sehari-hari.

Penulis selaku guru Mata Pelajaran PJOK di SMA Negeri 4 Malang, sudah melaksanakan pembelajaran Hybrid Learning. Pelaksanaan pembelajaran Hybrid Learning PJOK di SMAN 4 Malang sebagai berikut: (a) waktu efektif yang digunakan dalam pembelajaran adalah 30 menit per jam pelajaran, (b) peralatan yang dipergunakan untuk melaksanakan Hybrid Learning menggunakan peralatan sederhana yaitu handphone dan laptop, (c) beberapa aplikasi pilihan yang digunakan seperti: google met, zoom atau office 365 (d) jaringan wifi internet yang tersedia di kelas masih belum maksimal sehingga diperlukan kuota internet sendiri untuk mengakses internet.

Tentunya pelaksanaan pembelajaran Hybrid Learning PJOK di SMA Negeri 4 Malang jauh dari standar. Pelaksanaan pembelajaran PJOK secara Hybrid Learning terdapat kendala yaitu pada saat pelaksanaan di lapangan terbuka dan luas 
suara yang masuk ke dalam media akan tidak maksimal dengan peralatan yang sederhana. Dibutuhkan peralatan khusus untuk digunakan dalam kondisi seperti tersebut.

Kondisi yang ada dan kendala yang ada di lapangan menuntut seorang guru untuk lebih bisa berkreasi sehingga proses pembelajarang bisa berjalan dengan lancar. Pada saat pembelajaran Hybrid Learning PJOK bisa dilaksanakan melalui beberapa tahap, diantaranya: pertama tahap pendahuluan dilaksanakan secara klasikal. Kamera yang disediakan harus dapat merekam semua aktifitas yang dilakukan gutu dan peserta didik. Salah satu peserta didik bisa membantu guru untuk mengoperasikan kamera sehingga kegiatan pembelajaran bisa terlihat dan yang terjadi selama proses pembelajaran bisa terdengar oleh peserta didik di rumah. Peserta didik yang melaksanakan tatap muka bisa berkumpul di lapangan seperti halnya di dalam kelas. Guru membuka pembelajaran, menyampaikan materi, tujuan belajar, menggali informasi dan apersepsi, memotivasi serta manfaat materi kepada peserta didik. Tahap kedua adalah kegiatan inti yang dilaksanakan praktik di lapangan, peserta didik bisa mempraktikkan apa yang sudah dipelajari. Tahap ketiga seluruh peserta didik kumpul kembali untuk dilaksanakan kegiatan penutup yang terdiri dari: evaluasi, kesimpulan dan refleksi, serta menyampaikan materi pertemuan selanjutnya.

Kesimpulan yang diambil selama pelaksanaan Hybrid Learning bahwa proses pembelajaran tersebut dapat digunakan dalam proses Pembelajaran Tatap Muka Terbatas. Proses pembelajaran lebih efektif dan efisien karena seluruh peserta didik secara bersamaan dapat mengikuti pembelajaran yang ada. Hybrid Learning dapat meningkatkan motivasi belajar peserta didik dan menumbuhkan kemampuan berfikir kritis pada diri peserta didik. 


\section{PEMBELAJARAN TATAP MUKA TERBATAS PADA PEMBELAJARAN PENDIDIKAN JASMANI, OLAHRAGA, DAN KESEHATAN DI KOTA PALEMBANG}

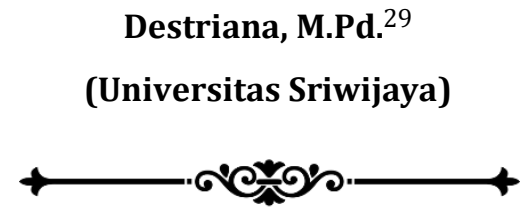

"Solusi dalam pembelajaran di masa Pelaksanakan PTMT pada matapelajaran PJOK dapat dilakukan melalui collaborative melalui lembar pengamatan yang terintegrasi dengan LKPD, orang tua dapat memantau kegiatan aktivitas belajar gerak peserta didik dan melaporkan aktivitas gerak tersebut kepada guru"

Dembelajaran Tatap muka terbatas adalah mengatur jumlah peserta didik di setiap kelas agar menjadi lebih sedikit dari jumlah normal. Pengaturan juga dilakukan pada meja dan kursi pelajar. Jumlah kursi dikurangi dan jaraknya diatur sesuai protokol, anak tidak perlu mengikuti pembelajaran penuh dalam sehari, tapi diatur sesuai kebutuhan di sekolah masing-masing, jumlah harinya tidak harus tiap hari, dari aspek materi pembelajaran, yang diberikan dalam PTM terbatas hanyalah materi yang paling esensial. Dengan kata lain, tidak semua materi diberikan kepada anak sehingga membuat anak pusing. Tatap muka

${ }^{29}$ Penulis lahir di Lubuklinggau, 01 Desember 1989, penulis merupakan Dosen Universitas Sriwijaya pada Prodi Pendidikan Jasmani dan Kesehatan. Penulis menyelesaikan gelar Sarjana Pendidikan Jasmani dan Kesehatan di Universitas Sriwijaya (2012), sedangkan gelar Magister Pendidikan Olahraga diselesaikan di Universitas Negeri Yogyakarta Program Studi Pendidikan Olahraga (2015). 
terbatas secara nasional tidak akan sama pada masing-masing provinsi, antar kabupaten ataupun kota, bahkan masingmasing kecamatan akan berbeda hal ini terjadi karena perbedaan kondisi perkembangan COVID-19 di masingmasing wilayah."

Pembelajaran tatap muka terbatas di Kota Palembang dimulai sejak tanggal 6 september 2021. Dinas Pendidikan Kota Palembang mengeluarkan aturan mengenai pelaksanaan kegiatan di sekolah sampai pulang dari sekolah yang mengikuti protokol kesehatan. Pada tanggal 6 september ini tidak semua sekolah sudah mengadakan pembelajaran tatap muka terbatas (PTMT) hanya 30 Sekolah Menengah Pertama dan 5 Sekolah Dasar, karena PTMT dilakukan secara bertahap.

Pelaksanaan PTMT di Kota Palembang jika pada saat pelaksanaan kemudian ditemukan kasus COVID-19 di sekolah, maka langkah yang perlu diambil adalah sekolah yang bersangkutan harus menghentikan PTMT selanjutnya melakukan 3T (testing, tracing, dan treatment). Tenaga pengajar maupun tenaga kependiddikan di sekolah yang mengalami sakit segera dirujuk ke rumah sakit, jika terindentifikasi covid maka harus menjalani isolasi dan dikoordinasikan dengan gugus COVID-19 setempat sehingga mendapatkan penanganan sebaik mungkin, selain itu sekolah juga ditutup sementara.

Evaluasi awal dilaksanakan setelah PTMT berjalan 2 minggu di Kota Palembang, PTMT berlangsung aman dari Covid,"., Untuk sekolah yang telah melaksanakan PTMT untuk Sekolah Menengah Pertama Negeri 100\%, SMP swasta 70\%, Sekolah Dasar Negeri 60\% dan PAUD 40 \%. Evaluasi selanjutnya adalah tanggal 30 september 2021 sudah aman dari covid19 sehingga awal bulan oktober seluruh sekolah dari setiap satuan pendidikan diizinkan melakukan PTMT.

Pelaksanaan awal PTMT di Kota Palembang adalah 2 jam dalam 1 kali pertemuan dengan 4 matapelajaran, sehingga 
jika dibagi untuk setiap matapelajarannya hanya mendapat waktu 30 menit. Seiring dengan perkembangan level PPKM dan penyebaran covid-19 sudah berkurang sekarang pembelajaran sudah menjadi 2 jam 40 dalam satu hari. Dengan 4 mata pelajaran dalam satu hari maka setiap mata kuliah mendapat waktu 40 menit.

Pendidikan jasmani adalah suatu proses pembelajaran melalui aktivitas jasmani yang didesain untuk meningkatkan kebugaran jasmani, mengembangkan keterampilan motorik, pengetahuan dan perilaku hidup aktif dan sehat, sportif, dan kecerdasan emosional, Rahayu, E. T. (2016). Mata pelajaran Pendidikan Jasmani Oaharaga dan Kesehatan adalah bagian integral dari pendidikan secara keseluruhan yang bertujuan untuk meningkatkan individu secara organik,, intelektual, neuromusculer dan emosional dengan melakukan aktivitas jasmani. Pembelajaran pendidikan jasmani adalah aktivitas jasmani yaitu dengan bergerak. Pembelajaran dalam PJOK adalah mengenalkan kompetensi keterampilan motorik dan pengetahuan dengan mengintegrasikan pengetahuan dengan aktivitas fisik dan dapat memberikan kontribusi bagi pendidikan di sekolah sehingga memberikan keseimbangan dalam mendidik anak secara keseluruhan dan konsisten (Ennis, 2011). PJOK sebagai area belajar dalam kurikulum sekolah sangat penting, apalagi untuk masa saat ini, sehingga peran teladan yang diasumsikan PJOK dalam desain kurikulum sebelumnya, dapat memimpin perubahan kurikulum nasional sekarang (Lynch, 2014).

Pelaksanaan PTMT pada pembelajaran PJOK di Kota Palembang sama dengan mata pelajaran lain yaitu 40 menit dalam setiap pertemuannya. Pelaksanaan pembelajaran tatap muka terbatas ini untuk mata pelajaran PJOK selain waktu dan jumlah siswa yang terbatas untuk pelaksanaan pembelajaran juga dibatasi dengan hanya teori saja belum ada pembelajaran praktek. Hal ini dilakukan untuk mengurangi penyebaran covid-19. Pembelajaran PJOK yang hanya teori dan tidak ada praktek di sekolah di Kota Palembang membuat 
banyak peserta didik menjadi bosan dan mengiinginkan pembelajaran berjalan seperti biasa sebelum pandemi yaitu PJOK harus praktek dengan tetap mematuhi protokol kesehatan covid19 karena pada saat matapelajaran PJOK inilah peserta didik bisa beraktivitas gerak sambil bermain, sesuai dengan pendapat Qomarrullah (2014) itu maka hakikat pendidikan jasmani mencakup semua unsur kebugaran, keterampilan gerakan fisik, kesehatan, permainan, olahraga, tari dan rekreasi, selain itu salah satu metode untuk pendidikan olahraga adalah metode perintah, dengan demonstrasi, ragam pemberian tugas, dan sedikit penjelasan (Supriyadi 2018), dengan hanya mengandalkan penjelasan dan tidak praktek dirasakan pembelajaran PJOK akan kehilangan unsur utama dalam pembelajarannya yaitu bergerak, selain itu peserta didik akan mengalami stres hal ini sejalan dengan penelitian Bahrodin, A., \& Widiyati, E, (2021) pada saat pembelajaran tatap muka secara terbatas mayoritas siswa mengalami stres akademik dengan kategori sedang.

Solusi dalam pembelajaran di masa Pelaksanakan PTMT pada matapelajaran PJOK dapat dilakukan melalui collaborative approach Herlina, H., \& Suherman, M. (2020). Collaborative approach yaitu guru membuat lembar kerja peserta didik (LKPD) untuk pembelajaran praktek atau bahan ajar cetak yang diantarkan ke rumah masing-masing siswa dengan orang tua siswa sebagai pemantau, selain itu guru membuat LKPD yang melibatkan orangtua dalam aktivitas belajar siswa. Melalui lembar pengamatan yang terintegrasi dengan LKPD, orang tua peserta didik dapat memantau kegiatan aktivitas belajar gerak peserta didik dan melaporkan aktivitas gerak tersebut kepada guru, hal inilah yang disebut kolaborasi antara guru dan oarang tua peserta didik. 


\section{Daftar Pustaka}

Bahrodin, A., \& Widiyati, E. (2021). Tingkat Stres Akademik Siswa Kelas Vi Pada Pembelajaran Tatap Muka (PTM) Terbatas. SAINSTEKNOPAK, 5(1).

Ennis, C. D. (2011). Physical Education Curriculum Priorities: Evidence for Education and Skillfulness. Quest, 63(1), 5-18. https://doi.org/10.1080/00336297.2011.10483659

Herlina, H., \& Suherman, M. (2020). Potensi Pembelajaran Pendidikan Jasmani Olahraga Dan Kesehatan (Pjok) Di Tengah Pandemi Corona Virus Disease (Covid)-19 Di Sekolah Dasar. Tadulako Journal Sport Sciences And Physical Education, 8(1), 1-7.

Lynch, T. (2014). Australian curriculum reform II. European Physical Education Review, 20(4), 508-524. https://doi.org/10.1177/1356336X14535166

Qomarrullah, Rif'iy. 2014. “Model Aktivitas Belajar Gerak Berbasis Permainan Sebagai Materi Ajar Pendidikan Jasmani (Penelitian Pengembangan Pada Siswa Kelas I Sekolah Dasar)." Indonesian Journal of Sports Science 1 (1): 76-88.

Rahayu, E. T. (2016). Strategi Pembelajaran Pendidikan Jasmani: implementasi pada pembelajaran pendidikan jasmani, olahraga, dan kesehatan. 


\title{
MODEL PEMBELAJARAN SELF REGULATED DALAM PENINGKATAN HASIL BELAJAR DALAM PEMBELAJARAN PENJAS DI SEKOLAH KEJURUAN
}

\author{
Rini Andriani, S.Pd. ${ }^{30}$
}

(SMKN 10 Medan)

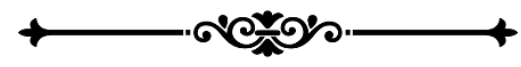

"Dengan penerapan model pendekatan belajar Self Regulated

Learning siswa termotivasi untuk melakukan kegiatan pembelajaran sehingga dapat fokus terhadap penyampaian materi yang diberikan dan tujuan dari pembelajaran yang telah ditetapkan tersebut dapat tercapai dengan maksimal"

\section{A. Pendahuluan}

$\mathrm{D}$ itingkat sekolah Menengah kejuruan (SMK) mutu Pendidikan jasmani pada tingkat pelajar selalu terus menerus diupayakan dilakukan untuk meningkatkan kebugaran jasmani pada pelajar yang ada di Indonesia, Hal tersebut terdapat pada program kegiatan pembelajaran dalam melakukan penelitian dan penerapan berbagai model pembelajaran dan meningkatkan mutu guru sekolah menengah kejuruan khususnya guru Pendidikan jasmani dalam proses pembelajaran,, hingga perubahan kurikulum seperti yang saat ini sedang dilakukan pemerintah melalui

${ }^{30}$ Penulis lahir di Bulu cina, 24 Januari 1979, penulis merupakan Guru di SMKN 10 Medan dalam bidang Pendidikan Jasmani Olahraga dan Kesehatan, penulis menyelesaikan gelar sarjana Ilmu Keolahragaan di Universitas Negeri Medan ( 2003 ) 
perubahan Kurikulum Nasional Tahun 2004 kepada Kurikulum Tingkat Satuan Pendidikan (KTSP).

Salah satu solusi yang dapat menumbuhkan motivasi belajar siswa dalam permasalahan model pembelajaran di sekolah berjalan dengan baik maka baiknya guru membuat suatu observasi serta dapat mensosialisasikan metode belajar dengan penerapan system belajar yang efesien dan efektif, Mengapa hal ini sangat diperlukan, system belajar yang bagaimana yang dapat menumbuhkan seorang siswa mau belajar dengan baik ?,seorang siswa memiliki aktivitas belajar yang baik maka siswa tersebut mempunyai semangat ataupun motovasi belajar dalam proses belajar.

Seseorang yang dapat menimbulkan tingkat kemauan baik dalam meningkatkan kemauan yang kuat ketika melaksanakan suatu kegiatan merupakan arti dari motivasi, hal tersebut meliputi kemampuan baik yang terdiri dari sumber luar individu (motivasi ekstrinsik) maupun dari dalam diri individu itu sendiri (motivasi intrinsik).

Pernyataan diatas dapat diperkuat dalam kutipan (Idzhar, 2016) antara lain "Seberapa kuat motivasi yang dimiliki individu akan banyak menentukan kualitas perilaku yang ditampilkannya, baik dalam konteks belajar, bekerja maupun dalam kehidupan lainnya".

\section{B. Self Regulated Learning}

Dalam kutipan Hasnah,2018 mengatakan bahwa, proses metakognisi yang mengatur proses perencanaan, pemantauan dan evaluasi dalam aktivitas belajar merupakan arti dari Self regulated laerning. Dalam melakukan Proses tersebut dilandasi oleh komitmen pencapaian tujuan belajar atau tugas - tugas akademis, sehingga tujuan belajar yaitu penguasaan, pengetahuan dan keterampilan dapat tercapai dengan keyakinan yang dimiliki pada kemampuan diri sendiri (self efficacy beliefs). 
Penerapan pendekatan model self regulated learning, terdapat pada kutipan Zimmerman dan Martinez Pons, 1990; yang mengatakan bahwa selft regulated learning atau pengelolaan diri dalam belajar merupakan suatu strategi belajar, yang kemudian berkembang dari teori triadic kognisi social dari bandura. Selain itu dalam kutipan Hidayat et al.,2000 beliau menyimpulkan dari pendapat Zimmerman dan Martinez pons bahwa untuk mencapai kegiatan belajar itu semua terdapat pada keterlibatan aspek motivasi yang ada pada siswa itu sendiri, dengan melakukan pengelolaan diri dalam belajar secara menyeluruh melalui aspek metakognisi, motivasi dan perilaku siswa dalam meningkatkan proses belajar.

Sesuai pernyataan di atas, maka saya tertarik menulis dan mengetahui "Apakah dalam penerapan pendekatan self regulated learning dapat memberikan pengaruh yang baik secara signifikan terhadap belajar peserta didik khususnya dalam belajar pendiidkan jasmani di tingkat sekolah menengah kejuruan (SMK)?"

Didalam Pelajaran pendidikan jasmani olahraga dan Kesehatan, pendekatan yang sering digunakan terdiri dari 7 , antara lain:

1. Pendekatan Pengetahuan-Keterampilan (KnowledgeSkill Approach)

2. Pendekatan Belajar (Learning Approach)

3. Pendekatan Motor Learning

4. Pendekatan Personalisasi

5. Pendekatan Sosialisi (Sosialization Approach)

6. Pendekatan Permainan Taktik (Tactical Game Approaches)

7. Spektrum Gaya Mengajar

Dari pendekatan pembelajaran Pendidikan jasmani diatas salah satunya yaitu pendekatan belajar atau learning 
approach, pendekatan tersebut menyebutkan untuk mempengaruhi Computer assisted instruction (CAI), dan metode kreativitas dan pemecahan masalah serta kompetensi dan proses belajar anak dengan metode terprogram (programmed instruction), selain itu juga pendekatan sosialisi atau sosilaization approach terhadap pembelajaran Pendidikan jasmani olahraga dan Kesehatan dapat mengarahkan para siswa untuk meningkatkan ketrampilan pribadi serta berkarya dalam apresiasi pembelajaranyang kreatif tetapi juga dapat menghantarkan siswa untuk lebih belajar interaksi bersosialisasi terhadap sesame teman di kelas ataupun dengan guru.

Dari penjelasan diatas dapat disimpulkan bahwa dengan metode penggunaan model belajar selft regulated learning dapat meningkatkan hasil belajar siswa menjadi baik dengan melalui pendekatan belajar dalam proses kegiatan belajar mengajar di kelas.

\section{Hasil Peningkatan Belajar dengan Self Regulated Learning}

Dengan penerapan model pendekatan belajar Self Regulated Learning siswa termotivasi untuk melakukan kegiatan pembelajaran sehingga siswa dapat fokus terhadap penyampaian materi yang diberikan sehingga tujuan dari pembelajaran yang telah ditetapkan tersebut dapat tercapai dengan maksimal. Maka dari itu dalam kegiatan belajar mengajar untuk siswa agar dapat fokus terhadap penyampaian materi yang di berikan sehingga apa tujuan dari proses belajar dapat tercapai dengan maksimal diperlukan penerapan model pendekatan pembelajaran yakni model belajar selft regulated learning.

Di bawah ini akan di jelaskan bebarap hal faktor yang dapat memperngaruhi motivasi atau semnagat belajar di pelajaran Pendidikan jasmani dan olahraga antara lain:

a. Siswa memiliki mental Kesehatan secara sehat fisik dan sehat psikis, hal ini dapat membantu siswa menigkatkan 
motivasi belajar dengan lebih bersemangat dan bergairah.

b. Untuk menumbuhkan motivasi belajar dibutuhkan Lingkungan belajar yang menyenangkan dan sehat serta memiliki udara yang sehat dan sejuk, dan keadaan sekitar yang menarik dengan memiliki sinar matahari yang cukup di sekitar lingkungan, suhu yang normal

c. Sarana dan prasarana sebagai faktor utama dalam proses belajar di lapangan seperti adanya faslitas alat yang baik yang menarik dan sesuai prosedur dalam perlengkapan pembelajaran.

d. Dalam pemberian pembelajaran khususnya pelajaran pendidikan jasmani yang dalam pembelajarannya sangat menuntut aktivitas gerak perkembangan motorik, maka metode belajar yang baik banyak menerapkan permainan game agar siswa tidak bosan.

e. Sistem belajar harus dimulai dari yang termudah terlebih dahulu agar siswa dapat mengikuti tingakatan proses belajar selanjutnya ke lebih sulit.

Demukianlah penjelasan sistem metode belajar menggunakan metode selft regulated dalam pelajaran Pendidikan jasmani, khususnya pada tingkat pelajar sekolah menengah kejuruan, semoga para guru yang ada di Indonesia terus bersemangat dalam berkontribusi mendidik dan memberikan pembelajaran ke siswa dengan temuan temuan yang terbaru, akhir kata penulis mengucapkan banyak terima kasih dan bermohon maaf jika dalam tulisan saya ini banyak kekurangan. 


\section{Daftar Pustaka}

Hasnah, S. (2018). Learning Siswa Unggulan Di Sekolah Sekolah Menengah Kejuruan Negeri 2 Medan Fakultas Psikologi Medan.

Hidayat, Y., Budiman, D., \& Mitarsih, T. (2000). Pengaruh penerapan pendekatan model selfregulated learning terhadap motivasi belajar siswa dalam pembelajaran penjas di Sekolah Dasar. Universitas Gajah Mada, Yogyakarta, Indonesia.

Idzhar, A. (2016). Peranan guru dalam meningkatkan motivasi belajar siswa. Jurnal office, 2(2), 221-228. 


\title{
PERAN OLAHRAGA TRADISIONAL DALAM MEMBENTUK PROFIL PELAJAR PANCASILA
}

\author{
Mia Kusumawati, M.Pd. ${ }^{31}$
}

(UNISMA Bekasi)

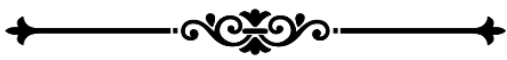

"Upaya guru dalam memadukan kegiatan pembelajaran pendidikan jasmani dengan nilai-nilai pancasila dapat memberikan arahan sekaligus melekat pada sikap siswa saat melakukan praktek dan melakukan perlombaan"

$\mathrm{O}$ lahraga tradisional adalah salah satu peninggalan leluhur yang memiliki kemurnian dan tradisi yang berbeda disetiap tempat. Indonesia sangat dikenal dengan kekayaan budaya tradisional yang sangat besar. Namun seiring dengan semakin lajunya perkembangan teknologi di era globalisasi ini, kekayaan budaya tradisional semakin lama semakin tenggelam. Semuanya mulai tenggelam seiring dengan pengaruh budaya asing, maraknya permainan playstation, game watch, computer game, dsb.

Seiring perubahan zaman maka berubah pula budaya permainan tradisional tersebut tentunya merupakan suatu keprihatinan bagi kita semua. Jika saat inii tidak berusaha

31 Mia Kusumawati lahir di Bandung, 14 Mei 1985, penulis merupakan Dosen UNISMA Bekasi dalam bidang ilmu pendidikan jasmani, Kesehatan dan rekreasi, penulis menyelesaikan gelar Sarjana Pendidikan Jasmani Kesehatan dan Rekreasi di Universitas Pendidikan Indonesia (2008), gelar Magister Pendidikan Olahraga diselesaikan di Universitas Pendidikan Indonesia Program Studi Pendidikan Olahraga (2011) 
melestarikan maka lambat laun budaya tradisional akan semakin tenggelam dan suatu saat akan punah, sehingga identitas bangsa Indonesia sebagai bangsa yang berkebudayaan tinggi akan hilang.

Sejak digulirkannya Undang Undang No. 3 Tahun 2005 tentang Sistem Keolahragaan Nasional, perhatian pemerintah untuk memunculkan dan melestarikan serta mengembangkan kembali budaya permainan tradisional sudah semakin terlihat. Hal ini terlihat pada saat digelarnya acara pemubukaan sebuah event olahraga nasional, selalu ditampilkan di antara atraksi lainnya adalah salah satu jenis olahraga tradiisonal ditampilkan. Bahkan, Kementerian Pemuda dan Olahraga Republik Indonesia, sudah menggulirkan dua (2) program kegiatan unggulan tingkat nasional, yaitu Festival. Olahraga Tradisional dan Invitasi Olahraga Nasional. Kedua even skala nasional ini dilaksanakan setiap dua tahun sekali secara bergantian. Untuk Festival jatuh pada tahun genap dan Invitasi dilaksanakan pada tahun ganjil. Sehingga menjadi pemantik bagi segenap pegiat olahraga tradisional untuk kembali menggalakkan dan mensosialisasikan olahraga tradisional yang ada selama ini mulai dalam pelaksanaan event-event sederhana sampai terbentuknya beberapa komunitas atau organisasi yang berorientasi pada pelestarian olahraga tradisional.

Olahraga tradisional memiliki manfaat yang tidak hanya sebatas sebagai ajang hiburan atau hanya berkaitan dengan olahraga rekreasi, tetapi juga memiliki kontribusi pada perkembangan olahraga pendidikan dan olahraga prestasi. Di olahraga pendidikan misalnya, olahraga tradisional dapat memberi edukasi kepada peserta didik bahkan khalayak tentang adanya warisan bangsa yang dapat memberi manfaat yang begitu banyak seperti, menjaga kesehatan, kebugaran, hiburan dan tentunya upaya melestarikan warisan budaya bangsa yang akan menjadi identitas bangsa Indonesia. Unsurunsur non fisik yang terdapat dalam olahraga tradisional 
memberikan pembelajaran dalam pembentukan karakter lewat bermain, seperti misalnya nilai juang, menghargai lawan, fair play, pantang menyerah, menghargai orang lain, saling percaya, kejujuran, kerjasama dan banyak lagi.

Selain itu olahraga tradisional ini juga dapat memberi manfaat pada olahraga prestasi, sudah banyaknya jenis olahraga tradisional yang dipertandingkan tentunya akan menuntut sebuah prestasi. Bahkan olahraga yang mudah dimodifikasi dapat dikembangkan menjadi model-model latihan yang dapat dikembangkan sebagai model latihan cabang olahraga prestasi sesuai dengan kebutuhan unsurunsur kebugaran jasmani yang dibutuhkan atlet.

Kecenderungan anak-anak zaman sekarang memilih permainan yang praktis, kondisi ini dikhawatirkan akan berdampak pada dirinya menjadi pribadi individualis dan sosial. Industri teknologi terus semakin berkembang menjadikan gadget semakin mudah untuk digunakan oleh orang banyak termasuk anak-anak yang juga menggunakannya sebagai sarana bermain.

Menyikapi perubahan yang akan dialami oleh Indonesia rentang waktu tahun 2020-2030 diperlukannya kesiapankesiapan dalam menghadapi kondisi tersebut yaitu fokus pada peningkatan produktivitas kerja yang baik. Namun untuk memperoleh produktivitas yang baik perlu didukung tingkat kebugaran yang baik.

Olahraga tradisional merupakan kegiatan aktivitas fisik yang efektif untuk meningkatkan kebugaran. Berbagai jenis olahraga tradisional cukup banyak yang kita miliki. Untuk memenuhi kebutuhan para penggerak olahraga tradisional diperlukannya panduan dalam mengembangkan olahraga tradisional tersebut.

Olahraga tradisional memiliki nilai-nilai yang terkandung didalamnya salah satunya adalah untuk menerapkan kedisiplinan, tanggung jawab, gotong royong atau bekerjasama dan masih banyak lagi sesuai dengan program 
pemerintah mengenai nilai-nilai pancasila. Maka peneliti ingin melakukan penelitian tentang olahraga tradisional dalam mengembangkan nilai-nilai pancasila.

Melihat betapa pentingnya olahraga bagi manusia khususnya bagi warga negara Indonesia sehingga pemerintah menuangkan payung hukum tentang olaharaga dalam sebuah UU, dimana berdasarkan UU No 3 Tahun 2005 tentang Sistem keolahragaan Nasional bab 2 pasal 4 menjelaskan "Keolahragaan nasional bertujuan memelihara dan meningkatkan kesehatan dan kebugaran, prestasi, kualitas manusia, menanamkan nilai moral dan akhlak mulia, sportivitas, disiplin, mempererat dan membina persatuan dan kesatuan bangsa, memperkukuh ketahanan nasional, serta mengangkat harkat, martabat, dan kehormatan bangsa"

Olahraga yang merupakan aktivitas fisik tentunya melibatkan unsur komponen fisik di dalamnya seperti kekuatan (strength), daya tahan (endurance), daya ledak otot (musculer endurence), kecepatan (speed), daya lentur (flexibility), kelincahan (agility), koordinasi (coodination), keseimbangan (balance), ketepatan (accuracy), dan reaksi (reaction)". M. Sajoto (1995: 8)

Sementara olaharaga tradisional Menurut (Sugito, 2019) olahraga tradisional adalah bentuk kegiatan olahraga yang berkembang di masyarakat, pada perkembangan selanjutnya olahraga tradisional sering dijadikan sebagai jenis permainan yang memakai ciri kedaerahan asli serta disesuaikan dengan tradisi budaya setempat. Selanjutnya (Sugito, 2019) menyatakan olahraga tradisional harus memenuhi dua persyaratan yaitu berupa "olahraga" dan sekaligus juga "tradisional" baik dalam memiliki tradisi yang telah berkembang selama beberapa generasi, maupun dalam arti sesuatu yang terkait dengan tradisi budaya suatu bangsa secara lebih luas.

Olahraga tradisional yang terdapat unsur komponen fisik tentu juga berkaitan tentang kebugaran jasmani yang 
melibatkan sistem gerak motorik yang ada pada tubuh. Menurut (Mahfud, 2020) bahwa struktur belajar didalam pendidikan jasmani berkaitan dengan bagaimana siswa belajar untuk mencapai tujuan pendidikan dengan menggunakan medium aktivitas fisik.

Gerakan motorik dapat dibedakan menjadi 2 yaitu motorik halus dan motorik kasar.Menurut (Mahfud, 2020) Keterampilan motorik halus adalah pengorganisasian penggunaan sekelompok otot-otot kecil seperti jari-jemari dan tangan yang sering membutuhkan kecermatan dan koordinasi mata dengan tangan. Contoh motorik halus yaitu: seperti memegang pena, memindahkan barang, menyusun puzzle dan lainnya yang berkaitan dengan aktifitas otot kecil. Sedangkan motorik kasar menurut (Mahfud, 2020) gerak motorik kasar adalah kemampuan yang membutuhkan koordinasi sebagian besar bagian tubuh anak. Gerakan motorik kasar melibatkan aktivitas otot-otot besar seperti otot tangan, kaki, dan seluruh tubuh. Motorik kasar berkaitan dengan berlati, mendorong, menendang, dan lainnya yang berkaitan dengan penggunaan otot besar. Tentu tidak semua warisan budaya dalam bentuk permainan dikategorikan sebagai olaharaga tradisional dimana olahraga pada dasarnya terlibatnya gerak motorik kasar yang adanya aktivitas otototot besar.

Sehingga dapat disimpulkan bahwa olahraga tradisional merupakan sebuah permainan aktivitas fisik berupa aktivitas otot besar yang dianggap oleh masyarakat serta dijadikan sebagai suatu tradisi budaya, selain sebagai wadah pelestarian budaya juga menjadi hiburan dan menjaga kebugaran jasmani. Pernyataan ini memperkuat perbedaan pengertian olahraga tradisional dengan permainan tradisional. Permainan tradisional hanya meliputi motorik halus, hanya melibatkan keterampilan tangan atau ketangkasan saja. 
Macam-macam olahraga tradisional adntara lain: Hadang, Bentengan, Sumpitan, Terompah panjang, Dagongan, Tarik tambang, Lari Balok, Gebuk Bantal, Patok Lele, Gasing.

Bahwa didalam permainan olahraga tradisional mengandung muatan sistem nilai seperti: membangun kerjasama atau gotong royong, kemudian toleransi tau berkebhinekaan global karena ketika satu tim tidak mungkin memiliki 1 budaya yang sama jenis permainan olahraga tradisionalpun terdiri dari berbagai daerah, selain itu siswa dituntun untuk mandiri salah satunya adalah bertanggung jawab atas dirinya sendiri karena didalam permainan olahraga tradisional selain mengembangkan tim mereka pun harus memiliki pengambilan keputusan yang cepat maka saat bermain olahraga tradisional pun siswa dituntut untuk bernalar kritis dan tentunya harus kreatif.

Aktif tidaknya siswa dalam belajar diawali dengan timbulnya rasa ketertarikan dan minat siswa itu sendiri dalam mengikuti pelajaran. Ketercapaian tujuan dalam pembelajaran adalah bukan dilihat dari terpenuhinya target materi yang harus diberikan, melainkan pada seberapa besar anak merasa tertarik untuk mengetahui dan memahami dari materi tersebut, untuk itu diperlukan suatu strategi pembelajaran yang efektif, menarik dan menyenangkan bagi siswa, salah satunya dengan belajar sambil bermain.

Karakteristik siswa SMP adalah masih senang bermain. Karakteristik ini menuntut guru SMP untuk melaksanakan kegiatan pembelajaran yang bermuatan permainan. Guru SMP seyogyanya merancang model pembelajaran yang memungkinkan adanya unsur permainan di dalamnya.

Nilai-nilai pancasila yang terdapat disekolah sebetulnya sudah mengarah ke nilai-nilai pancasila antara lain adalah sebelum melakukan pembelajaran siswa diminta untuk berdoa terlebih dahulu ini sesuai dengan sila ke 1 pancasila yaitu ketuhanan yang maha esa sesuai juga dengan point pertama yaitu Bangsa Indonesia menyatakan kepercayaannya 
dan ketaqwaannya terhadap Tuhan Yang Maha Esa. Kemudian ada juga point menghormati sesama pemeluk agama lain dan tetap bekerjasama dengan yang berbeda agama.

Begitupun dengan sila ke 2 yaitu kemanusiaan yang adil dan beradab yaitu di point dua dan selanjutnya tentang Mengakui persamaan derajat, persamaan hak dan kewajiban asasi setiap manusia, tanpa membeda-bedakan suku, keturunan, agama, kepercayaan, jenis kelamin, kedudukan sosial, warna kulit dan sebagainya. Mengembangkan sikap saling mencintai sesama manusia. Mengembangkan sikap saling tenggang rasa dan tepa selira. Mengembangkan sikap tidak semena-mena terhadap orang lain.

Sila ke 3 yaitu persatuan Indonesia yaitu dalam point pertama Mampu menempatkan persatuan, kesatuan, serta kepentingan dan keselamatan bangsa dan negara sebagai kepentingan bersama di atas kepentingan pribadi dan golongan. Sanggup dan rela berkorban untuk kepentingan negara dan bangsa apabila diperlukan. Mengembangkan rasa cinta kepada tanah air dan bangsa. Mengembangkan rasa kebanggaan berkebangsaan dan bertanah air Indonesia. Memelihara ketertiban dunia yang berdasarkan kemerdekaan, perdamaian abadi dan keadilan sosial. Mengembangkan persatuan Indonesia atas dasar Bhinneka Tunggal Ika.

Dalam sila ke 4 pancasila yaitu tentang Kerakyatan yang Dipimpin oleh Hikmah Kebijaksanaan dalam Permusyawaratan/Perwakilan sesuai dengan point Mengutamakan musyawarah dalam mengambil keputusan untuk kepentingan bersama. Musyawarah untuk mencapai mufakat diliputi oleh semangat kekeluargaan. Menghormati dan menjunjung tinggi setiap keputusan yang dicapai sebagai hasil musyawarah.

Kemudian dalam sila ke 5 pancasila yaitu tentang Keadilan Sosial Bagi Seluruh Rakyat Indonesia sesuai dengan point Mengembangkan perbuatan yang luhur, yang mencerminkan 
sikap dan suasana kekeluargaan dan kegotongroyongan. Mengembangkan sikap adil terhadap sesama. Menjaga keseimbangan antara hak dan kewajiban. Menghormati hak orang lain. Suka memberi pertolongan kepada orang lain agar dapat berdiri sendiri.

Guru berupaya memadukan kegiatan pembelajaran pendidikan jasmani dengan nilai-nilai pancasila. Memberikan arahan sekaligus melihat sikap siswa saat melakukan praktek dan melakukan perlombaan, nilai-nilai pancasila akan muncul ketika siswa sedang menghadapi kejuaraan pertandingan dan event.

\section{Daftar Pustaka}

Mahfud, M. \& Fahrizqi, E.B. (2020). Pengembangan Model Latihan Keterampilan Motorik Melalui Olahraga Tradisional Untuk Siswa Sekolah Dasar. Sport Science \& Education Journal. Vol 1, No 1.

Murtafi'atun (2018). Kumpulan Permainan Tradisional Nusantara, Yogyakarta; C-Klik Media.

Sagala, Syaiful, Konsep dan Makna Pembelajaran, Bandung: Alfabeta, 2010.

Sujarwo, Reorientasi Pengembangan Pendidikan di Era global, 2010 (http://pakguruonline.pendidikan.net)

Sugito. \& Alsabah, A.H. (2019). Permainan Tradisional Sebagai Pengembangan Daya Tarik Parawisata. Prosiding Seminar Nasional IPTEK Olahraga. ISSN 2622-0156. 


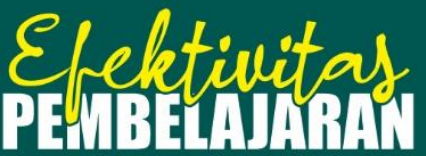 \\ SELAMA PELAKSANAAN

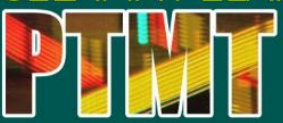

$\mathrm{P}$

endidikan pada prinsipnya harus berada di garda terdepan bagi bangsa Indonesia secara khusus bagi para generasi milineal bangsa ini, olehkarena estafet kepemimpinan yang akan melanjutnya negara ini dimasa akan datang terletak pada bagaimana mutu pendidikan saat ini. Dalam dunia olahraga, jika penulis analogikan bahwa Indonesia bercita-cita masuk dalam 10 besar ranking dunia di Olimpiade tahun 2032, maka jawabnya ada di pembinaan olahraga prestasi anak Indonesia usia 10-12 tahun saat ini. Pembinaan harus berjangka panjang yakni sekitar 8-10 tahun dan umur ini dijadikan acuan guna menyongsong prestasi 10 besar dunia di Olimpiade 2032. Dalam dunia pendidikan juga harus demikian, apa yang terjadi pada anak didik di tahun 2022, tentu akan dlihat bagaimana generasi bangsa Indonesia di tahun 2032. Apakah berelasi dengan munculnya generasi muda Indonesia yang handal menjawab tantangan era globalisasi di tahun 2032. Seperti apa kualifikasinya, ini adalah buah dari apa yang dilakukan pada anak didik di tahun 2022 ini. Olehkarena itu, proses pendidikan di pasca pandemi yang rencana akan di mulai tahun 2022 harus diwujudkan secara berkualitas.

Kehadiran buku bunga rampai ini sangatlah tepat di tengah kondisi pandemi Covid-19 varian baru. Semoga tulisan ringan dengan berbagai topik yang menarik disampaikan para penulis, memberi manfaat bagi para pembaca, guru, siswa, orangtua. Upaya menghilangkan virus Covid-19 terus dilakukan Pemerintah RI tetapi penyiapan SDM unggul tidak boleh terhenti olehkarena ganasnya penyebaran Virus corona yang berimbas membuat banyak pihal berpikir pesimis dan optimis yang bercampur aduk dalam pikirannya termasuk para guru dan siswa.

\section{Akademia Pustaka}

Perum. BMW Madani Kavling 16, Tulungagung

(7) https://akademiapustaka.com/

@redaksi.akademia.pustaka@gmail.com

f] @redaksi.akademia.pustaka

○)@akademiapustaka

(b) 081216178398

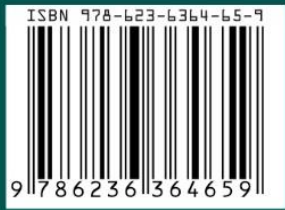

